This paper has been accepted for publication in Regional Environmental Change. The full publication may be viewed at: http://dx.doi.org/10.1007/s10113-016-0991-6. Please cite as: Robinson, S. and Gilfillan, D., 2016. Regional organisations and climate change adaptation in small island developing states, Regional Environmental Change, Online first: 1-16. Available at: http://dx.doi.org/10.1007/s10113-016-0991-6 (accessed mmddyyyy).

\title{
Regional Organisations and Climate Change Adaptation in Small Island Developing States
}

Stacy-ann Robinson ${ }^{1}$ and Daniel Gilfillan ${ }^{2 *}$

${ }^{1}$ Fenner School of Environment and Society, The Australian National University, 48 Linnaeus Way, Acton, ACT 2601, Australia | Tel: +61 (0) 261970017 | Email: stacy-ann.robinson@anu.edu.au

${ }^{2}$ Fenner School of Environment and Society, The Australian National University, 48 Linnaeus Way, Acton, ACT 2601, Australia | Tel: +61 (0) 261970017 | Email: daniel.gilfillan@anu.edu.au

*Corresponding author

\section{Abstract}

Regional organisations play a central role in coordinating regional climate change adaptation responses across small island developing states (SIDS), 58 countries that are particularly vulnerable to climate change and its impacts. The effectiveness of these organisations in coordinating adaptation efforts is underexplored in the academic literature, and this paper helps to fill the gap. By developing the Framework for Assessing Regional Organisations Coordinating Climate Change Adaptation, it qualitatively assesses the adaptation-related inputs, projects/programs and outputs of the Caribbean Community Climate Change Centre, the Secretariat of the Pacific Community and the Secretariat of the Pacific Regional Environment Programme. This assessment is enriched by data gathered through interviews with national and regional climate change and development officials in the Caribbean and Pacific. It finds that regional organisations are more effective with respect to their adaptation-related inputs and outputs but are less effective in coordinating adaptation projects/programs. It recommends that, in addition to differentiating organisational mandates, regional organisations should focus on resolving the major climate-related information deficit issues, helping countries to develop ready-tofinance investment projects, building national-level capacities to adapt, and supporting the creation of an enabling environment for climate change adaptation.

\section{Key Words}

Caribbean Community Climate Change Centre (CCCCC); climate change adaptation; effectiveness; regional organisations; Secretariat of the Pacific Community (SPC); Secretariat of the Pacific Regional Environment Programme (SPREP); small island developing states (SIDS)

\section{Acronyms and Abbreviations}

AIMS Atlantic, Indian Ocean, Mediterranean and South China Sea

AR5 Fifth Assessment Report of the Intergovernmental Panel on Climate Change 
This paper has been accepted for publication in Regional Environmental Change. The full publication may be viewed at: http://dx.doi.org/10.1007/s10113-016-0991-6. Please cite as: Robinson, S. and Gilfillan, D., 2016. Regional organisations and climate change adaptation in small island developing states, Regional Environmental Change, Online first: 1-16. Available at: http://dx.doi.org/10.1007/s10113-016-0991-6 (accessed mmddyyyy).

Acronyms and Abbreviations (cont'd)

CARICOM

Caribbean Community (and Common Market)

37 CCA

Climate change adaptation

38 CCCCC

Caribbean Community Climate Change Centre

Framework for Assessing Regional Organisations Coordinating Climate Change Adaptation

GCCA:PSIS

Global Climate Change Alliance: Pacific Small Island States

42 GEF

Global Environment Facility

43 IMF

International Monetary Fund

44 IPCC

Intergovernmental Panel on Climate Change

$45 \quad \mathrm{NE}$

No evidence

$46 \quad \mathrm{NGO}$

Non-governmental organisation

$47 \quad \mathrm{PACC}$

Pacific Adaptation to Climate Change Programme

$48 \quad$ PICTs

Pacific island countries and territories

49 P-SIDS

Pacific Small Island Developing States

50 SIDS

Small island developing states

Specific, measurable, achievable, realistic, time-bound

Pacific Islands Applied Geoscience Commission

Special Programme for Adaptation to Climate Change: Implementation of Adaptation

Measures in Coastal Zones

55 SPC

Secretariat of the Pacific Community (now called the Pacific Community)

Secretariat of the Pacific Regional Environment Programme

57 UN

UNFCCC

United Nations

United Nations Framework Convention on Climate Change

United Nations Office of the High Representative for the Least Developed Countries, Landlocked Developing Countries and Small Island Developing States

61

\section{Introduction}

Regional organisations play a key role in coordinating regional climate change adaptation (CCA) responses across small island developing states (SIDS). As an example, the Caribbean Community (CARICOM) created the Caribbean Community Climate Change Centre (CCCCC) as a specialised climate change coordination agency in 2005 (CCCCC, 2015a). SIDS are 58 countries grouped into three main geographic regions - the Atlantic, Indian Ocean, Mediterranean and South China Sea (AIMS), the Caribbean, and the Pacific (UN-OHRLLS, 2015a). These countries are particularly vulnerable to 
This paper has been accepted for publication in Regional Environmental Change. The full publication may be viewed at: http://dx.doi.org/10.1007/s10113-016-0991-6. Please cite as: Robinson, S. and Gilfillan, D., 2016. Regional organisations and climate change adaptation in small island developing states, Regional Environmental Change, Online first: 1-16. Available at: http://dx.doi.org/10.1007/s10113-016-0991-6 (accessed mmddyyyy).

current and future climate change impacts such as sea-level rise, increasing sea-surface temperatures and changing rainfall patterns (Nurse et al., 2014). Failure to adapt could result in the loss of those ecosystem services and infrastructure that support livelihoods (Nurse et al., 2014).

The Fifth Assessment Report (AR5) of the Intergovernmental Panel on Climate Change (IPCC) defines CCA as a "process of adjustment to actual or expected climate and its effects", which can take place in natural or human systems (IPCC, 2014, p. 1758). For SIDS, the process of CCA is complex. It is compounded by diverse vulnerabilities and a lack of resources (Nurse et al., 2014). To address this, national SIDS governments are taking part in supranational and/or regional efforts aimed at reducing shared climate- and non-climate-related vulnerabilities (Hewitson et al., 2014). This is a practical step for SIDS as they face broadly similar constraints to their adaptive capacities (Cherian, 2007). As a result, there is significant scope for regional organisations to expand their role and importance in coordinating regional CCA responses across SIDS. By coordinating we mean the role that these organisations play in bringing resources together to support the design, implementation, monitoring and evaluation of national-level CCA projects/programs in Member States. Despite this, the effectiveness of regional organisations in coordinating these responses across SIDS is underexplored in the academic literature. This paper helps to fill this gap, but does not seek to measure the adaptive capacity of the regional organisations.

As a first step in a cross-regional assessment of regional organisations, this paper aims to: (1) assess the effectiveness of regional SIDS-focussed organisations with respect to CCA, and (2) initiate a debate about whether the regional level is an appropriate scale for coordinating national-level CCA actions. The CCCCC, the Secretariat of the Pacific Community $\left(\mathrm{SPC}^{1}\right)$ and the Secretariat of the Pacific Regional Environment Programme (SPREP) are used as case study organisations. As no suitable assessment tool existed, an analytical framework was developed and applied to the three organisations' CCA-related inputs, projects/programs and outputs. Semi-structured interviews with senior regionaland national-level officials in the Caribbean and Pacific were used to enrich the analysis and drive the discussions and recommendations contained in this paper. This paper is, to the best of the authors' knowledge, one of the first academic cross-regional comparative studies of regional organisations coordinating CCA in SIDS; it provides the empirical evidence to support conclusions that may have otherwise only been suspected.

\section{Literature Review}

\subsection{Regional Organisations and SIDS}

\footnotetext{
${ }^{1}$ Despite recently changing its public name to the 'Pacific Community' to reflect its formal, legal name, the acronym 'SPC' has been retained by the organisation.
} 
This paper has been accepted for publication in Regional Environmental Change. The full publication may be viewed at: http://dx.doi.org/10.1007/s10113-016-0991-6. Please cite as: Robinson, S. and Gilfillan, D., 2016. Regional organisations and climate change adaptation in small island developing states, Regional Environmental Change, Online first: 1-16. Available at: http://dx.doi.org/10.1007/s10113-016-0991-6 (accessed mmddyyyy).

101 While there is no general agreement in the literature on the definition of 'regional organisations', there is some consensus on their characteristics. Regional organisations are a subset of international organisations (IMF, 2005), which are established to address existing problems that require collaborative action, including global environmental change and widening development gaps (Haas, 1990). Beattie (2013) argued that regional organisations can facilitate burden-sharing, reduce transaction costs and assist with developing and maintaining specialised knowledge. Other characteristics of regional organisations include being (1) comprised of "supranational institutions whose members are governments", (2) "located in a specific region of the world", (3) "created for many purposes", and (4) "established by means of a [formal] intergovernmental legal arrangement (e.g. a treaty)" (IMF, 2005, p. 1). Zyck (2013) noted that the focus of regional organisations should be multi-sectoral, and that mandates should be cooperative. These characteristics imply that regional organisations are created to explicitly promote cooperative action that addresses shared problems. For the purposes of this paper, a regional organisation is understood to be a subset of an international organisation that (1) is established by a formal intergovernmental agreement, (2) is located in a specific region, (3) has national governments as members, (4) is multi-sectoral in nature and approach, and (5) seeks to address shared problems.

SIDS currently have membership in 20 regional/sub-regional organisations (UN-OHRLLS, 2015b). The remoteness of these countries, combined with their financial, technical and other constraints, means that they can benefit from the economies-of-scale that regional organisations bring to the disbursement and management of financial and knowledge-based resources (ADB and Commonwealth Secretariat, 2006, p. ix; Beattie, 2013; Dornan and Newton Cain, 2014). In addressing shared problems such as climate change, regional organisations can support national SIDS governments in designing, implementing, monitoring and evaluating CCA projects/programs as well as by providing financial, technical and other support, especially where national-level resources are insufficient or inaccessible.

Regional cooperation efforts in the Caribbean have traditionally supported collective action to address common development challenges (Byron, 2014). In 1973, CARICOM was established to support economic integration, cooperation in functional areas such as health and education, and the coordination of foreign policies (Bishop et al., 2011). Following its establishment, CARICOM faced challenges such as the limited capacities of national governments to implement CARICOM decisions, low commitment of member governments to various cooperative efforts and a number of political and

132 financial failures (see Bishop et al., 2011; Girvan, 2011). These have resulted in repeated calls for either 133 the strengthening or abandonment of the Community, and cooperation efforts since the 1990s have 134 aimed to broaden the organisation's focus (Byron, 2014). Expanding its focus facilitated, for example, 
This paper has been accepted for publication in Regional Environmental Change. The full publication may be viewed at: http://dx.doi.org/10.1007/s10113-016-0991-6. Please cite as: Robinson, S. and Gilfillan, D., 2016. Regional organisations and climate change adaptation in small island developing states, Regional Environmental Change, Online first: 1-16. Available at: http://dx.doi.org/10.1007/s10113-016-0991-6 (accessed mmddyyyy).

the creation of specialised agencies such as the CCCCC, which is mandated to coordinate the region's response to climate change.

Regional cooperation efforts in the Pacific have shifted from a colonially-defined regional outlook, strongly influenced by Cold War thinking, to contemporary regional cooperation driven by regional organisations but also influenced by colonial powers such as Australia and New Zealand (Bryant-Tokalau and Frazer, 2006). The region is home to some of the earliest and most long-standing regional organisations in Asia and the Pacific, with the fore-runner of SPC established in 1947. Despite this, regional cooperation in the Pacific has not always been smooth and it "has not experienced the deepening of cooperation and integration that has been evident recently in many other regions" (ADB and Commonwealth Secretariat, 2006, p. xiii). Fry (2004) argued that there is no single consensus or vision for a Pacific regional community, and that global events and trends such as the "war against terror' influence the debate. Supporting this, Tarte (2014) suggested that new regional groupings such as the Pacific SIDS (P-SIDS) are emerging due to SIDS' growing dissatisfaction with existing regional frameworks.

While membership in regional organisations can have benefits for CCA in SIDS, the degree to which these organisations are effective in coordinating regional CCA responses has implications for regional CCA strategies and programming. Additionally, whether or how the organisations interact or the extent to which their mandates overlap can be important determinants of success. According to Nolte (2014), overlaps among regional organisations can occur both in membership and mandate, with impacts on effectiveness. These overlaps are influenced by a variety of factors which can affect cooperation levels, however, Nolte (2014) identified membership overlaps combined with mandate differentiation as a possible key to cooperative governance.

\subsection{Organisational Effectiveness}

Conceptually, organisational effectiveness is the degree to which an organisation is able to realise its goals (Etzioni, 1964). Measuring it is difficult, however, and the literature includes a variety of methods to gauge effectiveness. (e.g. Iwu et al., 2015; Quinn and Rohrbaugh, 1983). Sowa et al. (2004, p. 715) described organisational effectiveness as comprising "management effectiveness" and "program effectiveness", with two respective sub-components - capacities (processes and structures) and outcomes. Capacities relate to how an organisation operates, its resources, internal rules, standards and guidelines. Outcomes, as discussed by Mitchell (2008), are the longer-term results of an action, and are often not immediately measurable. The literature proposes many effectiveness models, including the goal-oriented, resource-oriented, process-oriented, and strategic constituency models. The goaloriented model focusses on outputs (see e.g. Button et al., 1996; Etzioni, 1960). The resource-oriented 
This paper has been accepted for publication in Regional Environmental Change. The full publication may be viewed at: http://dx.doi.org/10.1007/s10113-016-0991-6. Please cite as: Robinson, S. and Gilfillan, D., 2016. Regional organisations and climate change adaptation in small island developing states, Regional Environmental Change, Online first: 1-16. Available at: http://dx.doi.org/10.1007/s10113-016-0991-6 (accessed mmddyyyy).

model examines the organisation's ability to acquire necessary resources (see e.g. Wolfe and Putler, 2002). The process-oriented model focusses on effective and efficient use of resources (see e.g. Daft, 2012). The strategic constituency model examines the links between the organisation and its main stakeholders (see e.g. Connolly et al., 1980). For regional organisations coordinating CCA, each of these models provide insights into aspects of their functioning and effectiveness. Based on our conceptualisation of organisational effectiveness, we seek to qualitatively examine how the goals, resources, processes and strategic constituencies of regional organisations in the Caribbean and Pacific are brought together to support CCA in SIDS.

The measures of organisational effectiveness proposed in the literature are spread across multiple disciplines, including organisation theory, public and private sector effectiveness, and international environmental regime effectiveness. Sowa et al. (2004) identified both objective and perceptual measures. Perceptual measures, in this case, would rely on data gathered through interviews with individuals who have an intimate knowledge of the organisation. In the context of CCA, perceptual measures can support assessments of whether adaptation projects are reducing on-the-ground climate change impacts and vulnerabilities. Herman and Renz (2008) argued that good board management processes help keep the organisation in touch with stakeholders' needs and perceptions. Lockwood et al. (2010) used the principles of legitimacy, transparency, accountability, inclusiveness, fairness, integration, capability and adaptability to assess the governance of natural resource management. Complementing this, Taylor et al. (2014) highlighted visionary leadership in creating purpose through the linking of effort to outcome. The World Economic Forum (2014) explored effective leadership in international organisations and highlighted seven key indicators, including talent development and retention, strategic priority setting and broad stakeholder engagement. Yukl (2008), in exploring how leaders affect organisational effectiveness, discussed three components: process efficiency, human capital and ability to adapt to circumstance, and how these can be influenced by organisational leaders. These numerous measures provide scope to combine elements suitable for assessing regional organisational effectiveness in supporting the CCA actions of SIDS.

\section{Analytical Framework}

Organisational effectiveness is conceptually simple but for which there are no widely agreed measures (Iwu et al., 2015). This paper is primarily shaped by modern organisation theory and elements of neofunctionalism (see further details in Appendix 1 in the electronic supplementary material). It also builds on previous research by developing and applying discipline-appropriate components and indicators of organisational effectiveness. An interdisciplinary approach is used to identify and select organisational practices that are likely to improve organisational effectiveness (Cameron et al., 2011). A simple 
This paper has been accepted for publication in Regional Environmental Change. The full publication may be viewed at: http://dx.doi.org/10.1007/s10113-016-0991-6. Please cite as: Robinson, S. and Gilfillan, D., 2016. Regional organisations and climate change adaptation in small island developing states, Regional Environmental Change, Online first: 1-16. Available at: http://dx.doi.org/10.1007/s10113-016-0991-6 (accessed mmddyyyy).

203 approach to 'effectiveness' is taken here; it is both the ability of regional organisations to produce desirable CCA-related outputs and outcomes based on their inputs and projects/programs, as well as the degree to which they actually accomplish this (following Daft, 2012).

The authors developed the Framework for Assessing Regional Organisations Coordinating Climate Change Adaptation (FAROCCCA), a qualitative tool for understanding and rating the effectiveness of the regional organisations in this regard. FAROCCCA draws on multiple bodies of literature, including modern organisation theory (e.g. Daft, 2012), public and private sector effectiveness (e.g. Parhizgari and Ronald Gilbert, 2004), natural and shared resource management (e.g. Gupta et al., 2010), and research design and social measurement (e.g. Miller and Salkind, 2002). It also draws on regional frameworks and strategies such as the Caribbean's Regional Framework for

213 Achieving Development Resilient to Climate Change and The Framework for Pacific Regionalism, which replaced the Pacific Plan for Strengthening Regional Cooperation and Integration in 2014 (see CCCCC, 2012; PIF Secretariat, 2014). FAROCCCA incorporates elements of the four main models of organisational effectiveness identified in Section 5.2 above and comprises four components-input effectiveness, project/program effectiveness, output effectiveness and outcome effectiveness, the first three of which are considered in this paper. It has both objective and perceptual indicators (following Sowa et al., 2004) (see Figure 1). While covering the significant aspects of organisational effectiveness, FAROCCCA does not measure the adaptive capacity of organisations.

Input effectiveness is the first FAROCCCA component and is based on work by Oberlack and Neumärker (2013), Quinn and Rohrbaugh (1983) and Young (2011), among others. This component focusses on internal capacities i.e. how an organisation "operates, the structures [it has] in place, and the operating processes that dictate and direct employee action" (Sowa et al., 2004, p. 715). It is premised on the idea that an organisation that is well-managed internally is more likely to deliver high quality projects/programs and thus is more likely to produce better outputs and outcomes. The input effectiveness component has five sub-components (see Figure 1 on Page 8), comprising 34 objective and perceptual indicators (see Appendix 2 for a breakdown of FAROCCCA's components, subcomponents and indicators).

Project/program effectiveness is the second FAROCCCA component, which builds upon the work of authors such as Biermann and Bauer (2004), McDavid et al. (2013) and Weiss (2005). This component focuses on how well the organisation implements CCA-related projects/programs. It has eight sub-components and 20 indicators. 
This paper has been accepted for publication in Regional Environmental Change. The full publication may be viewed at: http://dx.doi.org/10.1007/s10113-0160991-6. Please cite as: Robinson, S. and Gilfillan, D., 2016. Regional organisations and climate change adaptation in small island developing states, Regional Environmental Change, Online first: 1-16. Available at: http://dx.doi.org/10.1007/s10113-016-0991-6 (accessed mmddyyyy).
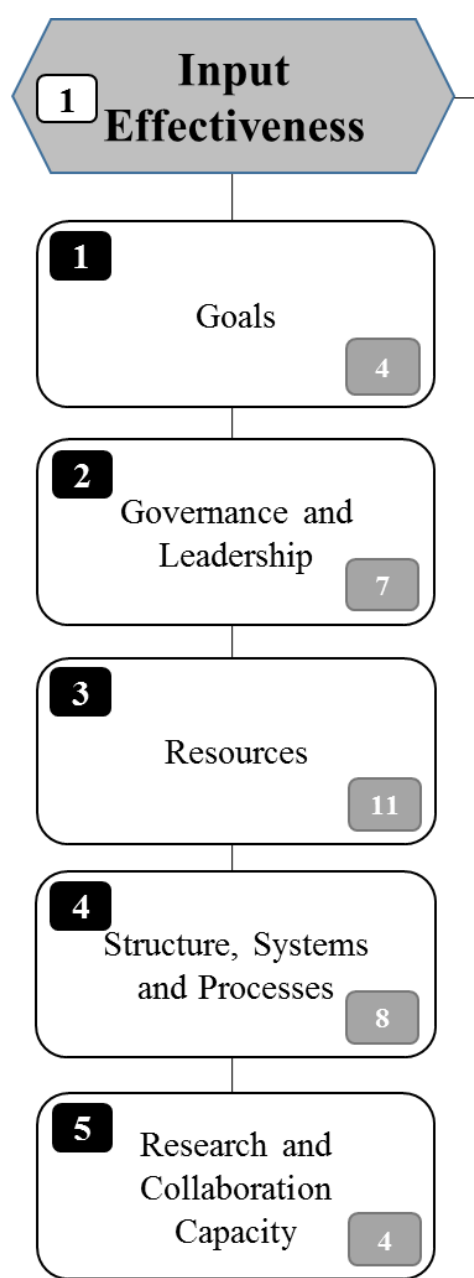
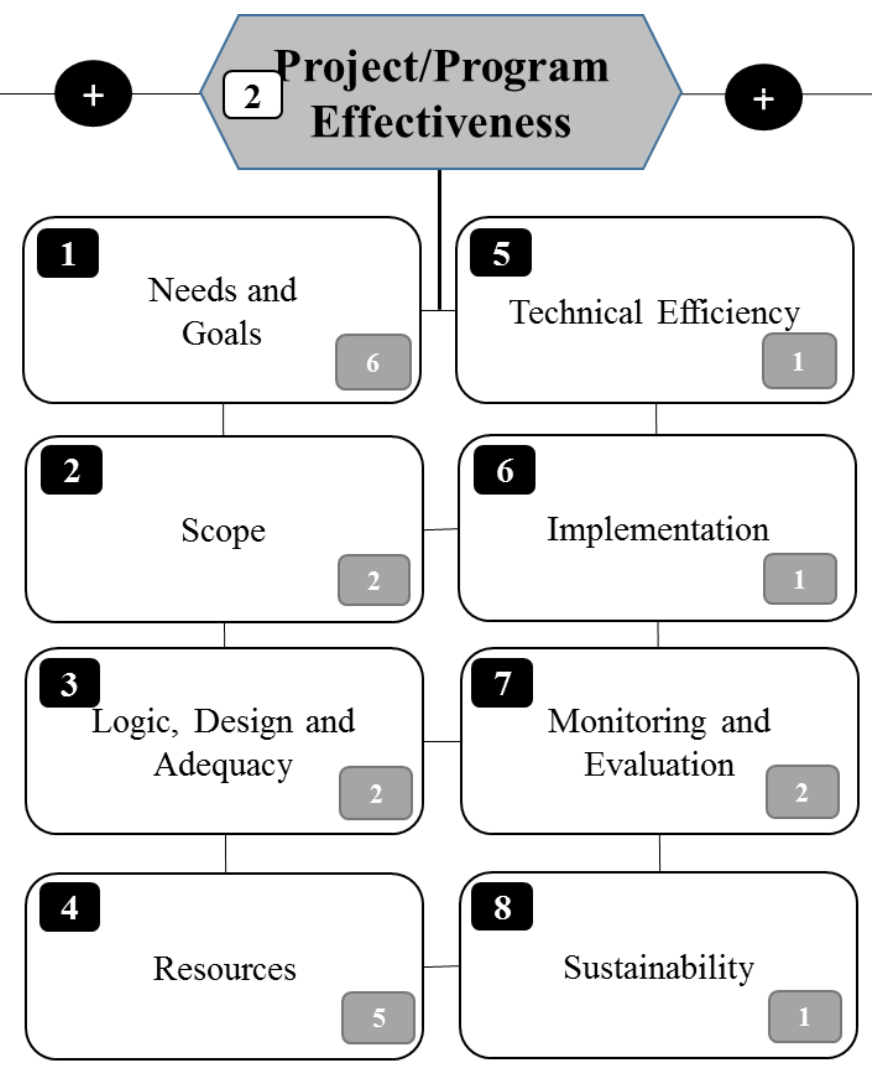

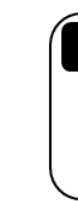
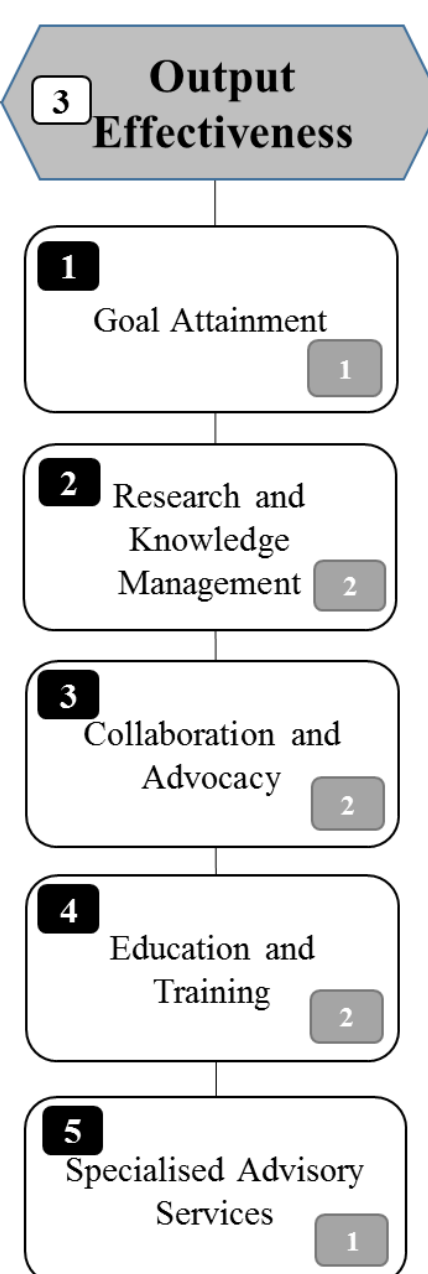

\begin{tabular}{|l|l|}
\hline \multicolumn{2}{|c|}{ LEGEND } \\
\hline $\mathbf{a}$ & Included component \\
\hline $\mathbf{a}$ & Excluded component \\
\hline $\mathbf{1}$ & Component number \\
\hline $\mathbf{1}$ & Sub-component number \\
\hline $\mathbf{1}$ & Number of indicators \\
\hline
\end{tabular}

\begin{tabular}{|c|l|}
\hline \multicolumn{2}{|c|}{ RATING SYSTEM } \\
\hline $\boldsymbol{x}$ & No \\
\hline$\triangleright$ & To some extent \\
\hline$\square$ & Yes \\
\hline$(\mathrm{NE})$ & No evidence \\
\hline
\end{tabular}


This paper has been accepted for publication in Regional Environmental Change. The full publication may be viewed at: http://dx.doi.org/10.1007/s10113-016-0991-6. Please cite as: Robinson, S. and Gilfillan, D., 2016. Regional organisations and climate change adaptation in small island developing states, Regional Environmental Change, Online first: 1-16. Available at: http://dx.doi.org/10.1007/s10113-016-0991-6 (accessed mmddyyyy).

237 Output effectiveness is the third FAROCCCA component. Work by Sowa et al. (2004) and others 238 support its inclusion. Output is understood as the direct product of an activity, and is distinct from 239 outcome, a longer-term result or consequence of an activity that may not be immediately measurable 240 following the activity (see e.g. Mitchell, 2008). Output effectiveness is, therefore, the degree to which 241 the direct product of an activity achieves its related specific, measurable, achievable, realistic and time242 bound (SMART) objectives, but which may not give a direct indication of whether an activity will achieve its strategic goals. In FAROCCCA, it has five sub-components and eight indicators.

Outcome effectiveness is the fourth FAROCCCA component. Given the uncertainty of future climate-related conditions, CCA outcomes are difficult to measure and in many instances, they are still unknown. Though a critical component, it is not included within the scope of this paper.

In this case, FAROCCCA is applied in a SIDS context, however, it is intended to have broader applicability to regional organisations coordinating CCA in other non-SIDS developing countries. Further, it is a framework that regional organisations can apply internally to self-assess their effectiveness. It is flexible, and with modifications, can be applied more broadly beyond CCA.

\section{Methods}

In this study, desk-based research and interviews are used to qualitatively assess the effectiveness of regional organisations in coordinating regional responses to climate change across SIDS.

\subsection{Case Study Selection}

Three of the 20 regional/sub-regional organisations in which SIDS have membership are included in this study - the CCCCC, as a specialised climate change agency of CARICOM, SPC and SPREP. Case study organisations were identified from a UN-OHRLLS list (see UN-OHRLLS, 2015b). The other 17 organisations were excluded because (1) they are sub-regional organisations $(N=3),(2)$ they are part of the UN system ( $N=10)$, (3) their strategic goals (including those of specialised agencies) do not have a climate change adaptation focus and are not multi-sectoral in nature ( $N=2$ ), and (4) SIDS do not make up at least $70 \%$ of their memberships $(N=2)$. The Indian Ocean Commission, the main AIMS regional organisation, was eliminated at (4).

Three projects/programs are included in this study-the CCCCC's Special Programme for Adaptation to Climate Change: Implementation of Adaptation Measures in Coastal Zones (SPACC), SPC's Global Climate Change Alliance: Pacific Small Island States (GCCA:PSIS) Project, and SPREP's Pacific Adaptation to Climate Change (PACC) Programme. These projects/programs (1) were primarily focussed on adaptation, (2) targeted multiple beneficiary countries, (3) were multi-year in length, and (4) were either completed or reported as being at least $80 \%$ complete at the time of writing. 
This paper has been accepted for publication in Regional Environmental Change. The full publication may be viewed at: http://dx.doi.org/10.1007/s10113-016-0991-6. Please cite as: Robinson, S. and Gilfillan, D., 2016. Regional organisations and climate change adaptation in small island developing states, Regional Environmental Change, Online first: 1-16. Available at: http://dx.doi.org/10.1007/s10113-016-0991-6 (accessed mmddyyyy).

SPACC was a four-year program funded by the Global Environment Facility (GEF) through the World Bank for US\$2.1 million (CCCCC, 2015b). It began in 2007 and supported three Eastern Caribbean SIDS to "implement specific (integrated) pilot adaptation measures [...], focused on biodiversity and land degradation along coastal and near-coastal areas" (CCCCC, 2015b, online). GCCA:PSIS was funded by the European Union for $€ 11.4$ million (SPC, 2011b). It supported nine smaller Pacific SIDS towards climate change mainstreaming and the implementation of adaptation strategies and projects, in collaboration with SPREP (SPC, 2011b). It was intended to run from 2011 to 2014 (SPC, 2011b). PACC is identified as "the first major climate change adaptation initiative in the Pacific region" (SPREP, 2014a, online). Involving 14 Pacific SIDS, it aimed to demonstrate "bestpractice adaptation in [...] coastal zone management, food security and food production, and water resources management" (SPREP, 2014a, online). Funded by the GEF and the Government of Australia, it began in 2009 with each participating country hosting a pilot project to demonstrate successful onthe-ground adaptation (SPREP, 2014a).

\subsection{Data Collection and Analysis}

Multiple sources of data on the respective organisations and their CCA-related inputs, projects/programs and outputs were identified. These included academic and grey literature, organisational and other websites, and, where publicly available, documents such as annual and audited financial reports, project/program evaluations and strategic plans. These were systematically reviewed by each researcher who collected extensive evidence against each of FAROCCCA's indicators from the above sources, and entered it into a table. Based on joint discussions of the evidence, each indicator was rated using the 'traffic light' method (see e.g. Gupta et al., 2010). Green ratings in Table 1 are represented as $\square$, showing that the researchers responded 'yes' to the indicator, and yellow ratings are represented as $\diamond$, showing that the researchers responded 'to some extent'. Red ratings are represented as $\boldsymbol{\otimes}$, showing that the researchers responded in the negative; indicators for which the researchers found no evidence are presented as '(NE)'. Four months after the data was originally coded, a sample of 24 of FAROCCCA's indicators was re-coded to ensure inter-coder reliability. Agreement between the original and re-coded sample was $83.3 \%$. Indicators coloured grey were not considered within the scope of this study. The ratings given were used as a way of drawing out interesting comparisons among the organisations rather than rating the organisations individually. This is in line with standard qualitative assessment methodologies (see e.g. Gupta et al., 2010).

The document analysis was enriched by semi-structured interviews with 36 regional- and national-level climate change officials. Both face-to-face and Skype interviews were conducted between August 2014 and August 2015 with officials from CCCCC, SPC and SPREP, as well as with 
This paper has been accepted for publication in Regional Environmental Change. The full publication may be viewed at: http://dx.doi.org/10.1007/s10113-016-0991-6. Please cite as: Robinson, S. and Gilfillan, D., 2016. Regional organisations and climate change adaptation in small island developing states, Regional Environmental Change, Online first: 1-16. Available at: http://dx.doi.org/10.1007/s10113-016-0991-6 (accessed mmddyyyy).

national officials from two Caribbean SIDS and two Pacific SIDS. Like those from the regional organisations, national officials were selected using purposive and snowballing techniques; their selection did not relate to the countries they represented. All interviewees had an understanding of national and regional adaptation processes, were senior in their named organisations, had oversight of a climate change-related portfolio, and had a minimum of five years' experience. Interview transcripts were developed and content analysis used to identify themes. All interviews were conducted in English and ran for an average of 55 minutes.

\subsection{Limitations}

This study has some limitations. First, data for the three organisations was not equally available. For example, annual and audited financial reports for the CCCCC are not publicly-available (CCCCC 2015, pers. comm. November 17). Second, the study does not collect data for perceptual indicatorsthese are isolated from those examined within the scope of this paper and are identified with a grey rating. For reasons of confidentiality and/or sensitivity, organisations themselves may be better placed to assess internal perceptions of their effectiveness. Third, it does not measure the outcomes of adaptation actions undertaken by the organisations. While important for determining whether current actions are facilitating effective and/or sustainable adaptation in SIDS, many outcomes are not yet known and future conditions are uncertain. Fourth, CCA is a complex task that involves many levels of government and issues of equity, power and legitimacy; this paper focusses only on the role that organisations fulfil in this complicated space. It is also worth noting that the organisations studied have their own limitations. They cannot oblige Member States to act or cooperate in CCA actions, but must work to achieve consensus through dialogue and negotiation. Additionally, because they use external funding to offset CCA costs, these organisations may be constrained by conditions associated with donor support.

\section{Results}

Results are presented according to the three FAROCCCA components considered in this paper - the effectiveness of the organisations' CCA-related inputs, projects/programs and outputs. While there is more detailed results and references in Appendices 3-5, the write-up in this section only covers the issues for which there was data for all three organisations. A summary of our analysis is presented in Table 1 on Page 12. 
This paper has been accepted for publication in Regional Environmental Change. The full publication may be viewed at: http://dx.doi.org/10.1007/s10113-0160991-6. Please cite as: Robinson, S. and Gilfillan, D., 2016. Regional organisations and climate change adaptation in small island developing states, Regional Environmental Change, Online first: 1-16. Available at: http://dx.doi.org/10.1007/s10113-016-0991-6 (accessed mmddyyyy).

Table 1: Results of the Application of FAROCCCA to CCCCC, SPC and SPREP

\begin{tabular}{|c|l|}
\hline \multicolumn{2}{|c|}{ RATING SYSTEM } \\
\hline$囚$ & No \\
\hline$\diamond$ & To some extent \\
\hline$\square$ & Yes \\
\hline$(\mathrm{NE})$ & No evidence \\
\hline & Perceptual indicator or indicator not rated in this paper \\
\hline
\end{tabular}

\begin{tabular}{|c|c|c|c|c|}
\hline SUB-COMPONENT & INDICATOR & $\mathrm{CCCCC}$ & SPC & SPREP \\
\hline & 1. Input Effectiveness & & & \\
\hline \multirow{4}{*}{ 1. Goals } & 1. Climate change adaptation was an initial goal of the organisation. & $\square$ & $\mathbf{x}$ & 区 \\
\hline & 2. Climate change adaptation is a current goal of the organisation. & $\nabla$ & 田 & 西 \\
\hline & $\begin{array}{l}\text { 3. The current strategic plan contains specific climate change adaptation } \\
\text { objectives. }\end{array}$ & $\diamond$ & $\diamond$ & $\nabla$ \\
\hline & $\begin{array}{l}\text { 4. There is no other regional organisation with similar climate change } \\
\text { adaptation goals. }\end{array}$ & $\square$ & 曰 & $\mathbf{\nabla}$ \\
\hline \multirow[t]{7}{*}{ 2. Governance and leadership } & 1. The Board provides visionary leadership and strategic direction. & & & \\
\hline & 2. The organisation evaluates organisational performance at least annually. & $\diamond$ & $\diamond$ & 甲 \\
\hline & $\begin{array}{l}\text { 3. Executive management (can also include members of the Board/Governing } \\
\text { Body) decision-making is done by consensus or majority vote. }\end{array}$ & $\nabla$ & $\square$ & $\square$ \\
\hline & $\begin{array}{l}\text { 4. Executive management staff (can also include members of the } \\
\text { Board/Governing Body) are qualified and/or equipped to achieve the goals } \\
\text { of the organisation. }\end{array}$ & $\nabla$ & 甲 & च \\
\hline & 5. Executive management staff disclose potential conflicts of interest. & & & \\
\hline & 6. The organisation attracts, retains and develops talent. & $\diamond$ & $\diamond$ & $\diamond$ \\
\hline & $\begin{array}{l}\text { 7. Leaders create a dynamic organisational culture, making the organisation } \\
\text { a desirable place to work. }\end{array}$ & & & \\
\hline \multirow[t]{3}{*}{ 3. Resources } & $\begin{array}{l}\text { 1. There are staff members exclusively dedicated to climate change } \\
\text { adaptation. }\end{array}$ & $(\mathrm{NE})$ & $\diamond$ & $\square$ \\
\hline & 2. Staff are qualified and have experience in climate change adaptation. & च & $\diamond$ & 甲 \\
\hline & Staff are qualified and have experience in project/program management. & $\square$ & 四 & $\square$ \\
\hline
\end{tabular}


This paper has been accepted for publication in Regional Environmental Change. The full publication may be viewed at: http://dx.doi.org/10.1007/s10113-0160991-6. Please cite as: Robinson, S. and Gilfillan, D., 2016. Regional organisations and climate change adaptation in small island developing states, Regional Environmental Change, Online first: 1-16. Available at: http://dx.doi.org/10.1007/s10113-016-0991-6 (accessed mmddyyyy).

\begin{tabular}{|c|c|c|c|c|}
\hline & 4. Staff participate in ongoing training programs. & $\diamond$ & 田 & $\nabla$ \\
\hline & 5. Staff performance is appraised (formally or informally) at least annually. & $(\mathrm{NE})$ & $\nabla$ & $\square$ \\
\hline & 6. The organisation has untied funding. & $\nabla$ & $\nabla$ & $\diamond$ \\
\hline & $\begin{array}{l}\text { 7. The organisation has funds exclusively dedicated to climate change } \\
\text { adaptation. }\end{array}$ & $\nabla$ & $\nabla$ & $\square$ \\
\hline & 8. External funding to the organisation has increased over the past 5 years. & $\diamond$ & 甲 & $\square$ \\
\hline & 9. The organisation has multiple funding sources. & $\square$ & $\nabla$ & $\nabla$ \\
\hline & 10. The organisation has financial reserves. & 可 & 甲 & 凶 \\
\hline & $\begin{array}{l}\text { 11. The organisation has sufficient technological resources (e.g. intellectual } \\
\text { property rights, patents, copyright, software licences etc.) to carry out its } \\
\text { climate change adaptation mandate. }\end{array}$ & & & \\
\hline \multirow{8}{*}{$\begin{array}{l}\text { 4. Structure, systems and } \\
\text { processes }\end{array}$} & 1. There is a low degree of hierarchy (i.e. few hierarchical levels). & & & \\
\hline & $\begin{array}{l}\text { 2. The organisation has a human resource management system that supports } \\
\text { the shaping of organisational culture and staff recruitment, training, } \\
\text { development and retention. }\end{array}$ & & & \\
\hline & $\begin{array}{l}\text { 3. There is a financial management system that meets International Financial } \\
\text { Reporting Standards (IFRS) or its equivalent. }\end{array}$ & $\diamond$ & $\nabla$ & $\nabla$ \\
\hline & $\begin{array}{l}\text { 4. The organisation applies risk management principles in its decision- } \\
\text { making processes. }\end{array}$ & & & \\
\hline & $\begin{array}{l}\text { 5. The organisation has a centralised, user-friendly internal data management } \\
\text { system. }\end{array}$ & & & \\
\hline & $\begin{array}{l}\text { 6. The organisation has a user-friendly project/program management system } \\
\text { (e.g. that supports staff to identify, schedule and track resources etc.). }\end{array}$ & & & \\
\hline & 7. There are mechanisms that support vertical and horizontal communication. & & & \\
\hline & 8. There are internal dispute resolution protocols. & & & \\
\hline \multirow{4}{*}{$\begin{array}{l}\text { 5. Research and collaboration } \\
\text { capacity }\end{array}$} & 1. The organisation has plans and policies that support research. & 口 & 甲 & $\square$ \\
\hline & 2. There are organisational funds allocated for research. & $(\mathrm{NE})$ & 甲 & $\nabla$ \\
\hline & $\begin{array}{l}\text { 3. The organisation has equipment, expertise and/or resources (e.g. access to } \\
\text { journal articles etc.) for research. }\end{array}$ & $\square$ & $\square$ & $\square$ \\
\hline & $\begin{array}{l}\text { 4. The organisation's current strategic plan (or a similar document) outlines } \\
\text { plans for collaboration with multiple stakeholders on adaptation-related } \\
\text { initiatives. }\end{array}$ & 甲 & $\square$ & $\square$ \\
\hline
\end{tabular}


This paper has been accepted for publication in Regional Environmental Change. The full publication may be viewed at: http://dx.doi.org/10.1007/s10113-0160991-6. Please cite as: Robinson, S. and Gilfillan, D., 2016. Regional organisations and climate change adaptation in small island developing states, Regional Environmental Change, Online first: 1-16. Available at: http://dx.doi.org/10.1007/s10113-016-0991-6 (accessed mmddyyyy).

\begin{tabular}{|c|c|c|c|c|}
\hline \multicolumn{5}{|c|}{ 2. Project/Program Effectiveness } \\
\hline \multirow[t]{6}{*}{ 1. Needs and goals } & $\begin{array}{l}\text { 1. The project documents contain evidence that the project/program fills an } \\
\text { existing need with relation to climate change adaptation. }\end{array}$ & $\square$ & $\square$ & $\square$ \\
\hline & $\begin{array}{l}\text { 2. The project/program's adaptation components could be considered } \\
\text { 'transformational' (i.e. the project/program focusses on "larger, more } \\
\text { profound system changes" and requires a "paradigm shift" in the way it is } \\
\text { framed and implemented). }\end{array}$ & & & \\
\hline & 3. Climate change adaptation is a goal of the project/program. & $\square$ & $\square$ & $\square$ \\
\hline & $\begin{array}{l}\text { 4. The project/program's goals reflect the long-range impacts of climate } \\
\text { change. }\end{array}$ & $\nabla$ & $\square$ & $\square$ \\
\hline & $\begin{array}{l}\text { 5. The project/program's objectives relating to climate change adaptation are } \\
\text { specific, measurable, achievable, realistic and time-bound (SMART). }\end{array}$ & $\diamond$ & $\diamond$ & $\diamond$ \\
\hline & $\begin{array}{l}\text { 6. Member Countries were involved in developing the climate change } \\
\text { adaptation components of the project/program. }\end{array}$ & $\diamond$ & $\nabla$ & $\nabla$ \\
\hline \multirow[t]{2}{*}{ 2. Scope } & $\begin{array}{l}\text { 1. The project/program addresses multiple climate or climate-induced } \\
\text { vulnerabilities (e.g. vulnerability to sea-level rise, increased sea surface } \\
\text { and air temperature, changing rainfall patterns etc.). }\end{array}$ & $\square$ & $\square$ & $\square$ \\
\hline & $\begin{array}{l}\text { 2. The project/program addresses multiple non-climate-induced } \\
\text { vulnerabilities (e.g. poverty, deforestation etc.). }\end{array}$ & 冈 & $\square$ & $\square$ \\
\hline \multirow[t]{2}{*}{ 3. Logic, design and adequacy } & $\begin{array}{l}\text { 1. The logic/design of the project/program's climate change adaptation } \\
\text { components is evidence-based, in the context of SIDS. }\end{array}$ & $\diamond$ & $\diamond$ & $\square$ \\
\hline & $\begin{array}{l}\text { 2. The project documents contain evidence that the logic/design of the } \\
\text { project/program's climate change adaptation components is an effective } \\
\text { means to achieve its objectives. }\end{array}$ & $\diamond$ & $\diamond$ & $\diamond$ \\
\hline \multirow[t]{5}{*}{ 4. Resources } & 1. Staff members are assigned exclusively to the project/program. & 冈 & $\diamond$ & $\square$ \\
\hline & $\begin{array}{l}\text { 2. The project/program team includes staff members with qualifications and } \\
\text { experience in climate change adaptation. }\end{array}$ & $\diamond$ & $\nabla$ & $\diamond$ \\
\hline & $\begin{array}{l}\text { 3. The project/program team includes staff members with qualifications and } \\
\text { experience in project/program management. }\end{array}$ & $\square$ & $\nabla$ & $\diamond$ \\
\hline & $\begin{array}{l}\text { 4. The project documents contain evidence that there are sufficient staff } \\
\text { members to achieve the project/program objectives. }\end{array}$ & & & \\
\hline & $\begin{array}{l}\text { 5. The project documents contain evidence that there is sufficient funding for } \\
\text { the project/program's climate change adaptation components. }\end{array}$ & 冈 & $\diamond$ & 冈 \\
\hline
\end{tabular}


This paper has been accepted for publication in Regional Environmental Change. The full publication may be viewed at: http://dx.doi.org/10.1007/s10113-0160991-6. Please cite as: Robinson, S. and Gilfillan, D., 2016. Regional organisations and climate change adaptation in small island developing states, Regional Environmental Change, Online first: 1-16. Available at: http://dx.doi.org/10.1007/s10113-016-0991-6 (accessed mmddyyyy).

\begin{tabular}{|c|c|c|c|c|}
\hline 5. Technical efficiency & $\begin{array}{l}\text { 1. The project documents contain evidence that the project/program provides } \\
\text { value for money (cost vs. outputs). }\end{array}$ & $\diamond$ & 冈 & 曰 \\
\hline 6. Implementation & $\begin{array}{l}\text { 1. The project/program's climate change adaptation components are } \\
\text { implemented, as proposed. }\end{array}$ & 凶 & $\diamond$ & $\diamond$ \\
\hline \multirow[t]{2}{*}{ 7. Monitoring and evaluation } & 1. The project/program is internally monitored and evaluated. & $\diamond$ & $\square$ & $\square$ \\
\hline & 2. The project/program is externally monitored and evaluated. & $\square$ & (NE) & $\nabla$ \\
\hline 8. Sustainability & 1. There are sustained outputs from the project/program. & & & \\
\hline \multicolumn{5}{|c|}{ 3. Output Effectiveness } \\
\hline 1. Goal attainment & $\begin{array}{l}\text { 1. There is evidence in the most recent annual report or evaluation that the } \\
\text { climate change adaptation-related objectives of the organisation are being } \\
\text { achieved. }\end{array}$ & $(\mathrm{NE})$ & $\diamond$ & $\diamond$ \\
\hline \multirow[t]{2}{*}{$\begin{array}{l}\text { 2. Research and knowledge } \\
\text { management }\end{array}$} & $\begin{array}{l}\text { 1. The organisation produces and/or publishes research that is relevant to } \\
\text { climate change adaptation at least annually. }\end{array}$ & $\diamond$ & $\square$ & $\square$ \\
\hline & $\begin{array}{l}\text { 2. The organisation makes climate change adaptation-relevant research } \\
\text { publicly available. }\end{array}$ & $\square$ & $\square$ & $\square$ \\
\hline \multirow[t]{2}{*}{ 3. Collaboration and advocacy } & $\begin{array}{l}\text { 1. There is evidence that the organisation collaborates with multiple } \\
\text { stakeholders to undertake climate change adaptation-related activities. }\end{array}$ & $\square$ & $\square$ & $\square$ \\
\hline & $\begin{array}{l}\text { 2. The organisation advocates for political, financial and/or other climate } \\
\text { change support for its Member Countries in various fora at different scales. }\end{array}$ & $\square$ & $\diamond$ & $\nabla$ \\
\hline \multirow[t]{2}{*}{ 4. Education and training } & $\begin{array}{l}\text { 1. The organisation undertakes climate change adaptation stakeholder and/or } \\
\text { public awareness activities. }\end{array}$ & $\nabla$ & $\square$ & $\nabla$ \\
\hline & $\begin{array}{l}\text { 2. The organisation develops and/or implements training programs for } \\
\text { stakeholders in issues related to climate change adaptation. }\end{array}$ & $\square$ & $\square$ & $\square$ \\
\hline $\begin{array}{l}\text { 5. Specialised advisory } \\
\text { services }\end{array}$ & $\begin{array}{l}\text { 1. The organisation provides specialised climate change adaptation-related } \\
\text { advice to Member Countries and/or other stakeholders. }\end{array}$ & $\square$ & $\diamond$ & 曰 \\
\hline
\end{tabular}


This paper has been accepted for publication in Regional Environmental Change. The full publication may be viewed at: http://dx.doi.org/10.1007/s10113-016-0991-6. Please cite as: Robinson, S. and Gilfillan, D., 2016. Regional organisations and climate change adaptation in small island developing states, Regional Environmental Change, Online first: 1-16. Available at: http://dx.doi.org/10.1007/s10113-016-0991-6 (accessed mmddyyyy).

\subsection{Input Effectiveness}

The three organisational mandates range from an economic and social development directive, through broader environmental protection, to a specific focus on climate change. The CCCCC was the most recently established of the three organisations, set up in 2005 to coordinate responses to climate change in the Caribbean (CARICOM Secretariat, 2011). SPC was originally established as an intergovernmental advisory body on economic and social development matters in 1947 (SPC, 1947). SPREP began more recently as a joint initiative of SPC and three other supranational organisations in the 1970s, and became an independent intergovernmental organisation in 1993 with a mandate to promote cooperation for environmental improvement and protection and to ensure sustainable development (SPREP, 2014c). The original mandates of both Pacific organisations have evolved over time; current strategic plans are focussed towards CCA. SPC's most recent strategic plan specifies "[i]ncreased resilience of Pacific island countries and territories (PICTs) to the water-related impacts of climate change and disaster" as a strategic objective (SPC, 2013, p15). SPREP's most recent strategic plan states that "[b]y 2015, all Members will have strengthened capacity to respond to climate change" through adaptation and other measures (SPREP, 2011, p. 16). This highlights that all three organisations have a current, explicit focus on CCA.

Beyond their mandates and strategic priorities, all three organisations have frameworks that support their adaptation activities. In both the Caribbean and Pacific, the organisations attract staff with CCA and project management qualifications and experience. For example, the CCCCC's current Deputy Director and Science Advisor has a PhD in organic chemistry, has worked as a project manager focussing on CCA since 1997 (CCCCC, 2015b; Trotz, n.d.), and was a review editor of the IPCC Fourth Assessment Report's chapter on small islands (see IPCC, 2007, p. 687). This adaptation and project management expertise is supported by specific funding for adaptation projects at the three organisations, which all have multiple funding sources. For example, in addition to donor funding, the CCCCC has established a reserve fund, seeded by the Government of Trinidad and Tobago (CCCCC, 2015a, online), and SPC's 2013 financial report shows funding from 34 donors and 26 Member States (SPC, 2014c). In spite of some year-to-year variations, external funding to both SPC and SPREP has increased over the last five years, their financial reporting meets International Financial Reporting Standards, and their financial reports are publicly available (SPREP, 2014b, p.56; SPC, 2011a, p. 5). The CCCCC has established a Finance and Audit Sub-Committee to strengthen financial oversight (CCCCC, 2015a, online). Additionally, all three organisations have policies and plans that support climate research, and have the expertise to undertake research. SPC and SPREP's financial accounts both show funding allocated to research activities. The CCCCC participates in a research consortium that includes the University of the West Indies; it undertakes climate and economic modelling (Colley et al., 2011), and 
This paper has been accepted for publication in Regional Environmental Change. The full publication may be viewed at: http://dx.doi.org/10.1007/s10113-016-0991-6. Please cite as: Robinson, S. and Gilfillan, D., 2016. Regional organisations and climate change adaptation in small island developing states, Regional Environmental Change, Online first: 1-16. Available at: http://dx.doi.org/10.1007/s10113-016-0991-6 (accessed mmddyyyy).

has a record of reporting on its scientific research activities to the UNFCCC (see CCCCC, 2008). This highlights the success of all three organisations in attracting qualified and experienced staff and funding from multiple sources, and accessing the requisite expertise to undertake scientific research, placing them in a position to effectively support regional adaptation efforts.

Despite these positive aspects of input effectiveness, there are some areas where the organisations did not rate quite so well. SPC noted in a paper presented to a Meeting of the Committee of Representatives of Governments and Administrations in 2014 that the organisational requirement for fixed-term staff contracts has had a negative impact on job security, leading to difficulties in attracting and retaining the best staff (SPC, 2014a). In 2014, SPREP spent funds from its reserve facility to cover costs associated with reviews, translations, meetings and unexpected medical fees; this resulted in its total reserve funds being in deficit by over US $\$ 400,000$ at year end (SPREP, 2015b). The CCCCC does not make its financial accounts publicly available, obscuring the state of the organisation's financial health. These less positive ratings are isolated points and are just an indication of areas where these organisations could improve their CCA-related input effectiveness.

\subsection{Project/Program Effectiveness}

All three organisations assessed have directly implemented adaptation projects. The projects assessed as part of this research are all pilot projects, with evidence that they were filling an adaptation need. The GCCA:PSIS project implemented by SPC acknowledged the particular development context of SIDS and, in response, worked with national government departments to choose priority sectors and projects that fitted within the allocated budgets (SPC, 2012). Like the PACC Programme implemented by SPREP, it also took into consideration a range of non-climate change-related vulnerabilities such as isolation and population growth (SPREP, 2015a; GCCA et al., 2014). These projects were internally monitored and evaluated, with SPREP producing quarterly internal monitoring reports, some of which are publicly available. Filling a need, working with national governments to select focus areas, and monitoring project implementation all play an important role in running a successful project.

Despite the positive points above, there were factors that point to a lack of evidence-based project design — none of the project documents reviewed contained evidence that their designs would effectively achieve their adaptation objectives. In the case of the SPACC Programme, the Terminal Evaluation revealed that the CCCCC experienced challenges with the technical design and management of the project - two of the seven pilot interventions were dropped because of "land tenure issues"; also, significant project implementation time was taken up with design negotiations and bidding document preparation, rather than improving operations and monitoring implementation (World Bank, 2012, p. 9). There was also a lack of national-level ownership. While member country governments endorsed 
This paper has been accepted for publication in Regional Environmental Change. The full publication may be viewed at: http://dx.doi.org/10.1007/s10113-016-0991-6. Please cite as: Robinson, S. and Gilfillan, D., 2016. Regional organisations and climate change adaptation in small island developing states, Regional Environmental Change, Online first: 1-16. Available at: http://dx.doi.org/10.1007/s10113-016-0991-6 (accessed mmddyyyy).

the program, the same governments were not prepared for country project coordinators to speak on their behalf (World Bank, 2012). SPC faced similar issues in Nauru-there were delays in gaining government endorsement, and an eventual return to the design phase of the project (SPC, 2014b). Across all three organisations, the FAROCCCA assessment highlighted project/program effectiveness as the area requiring the most attention.

\subsection{Output Effectiveness}

All three organisations rated well on achieving their immediate outputs. They all run public awareness campaigns and collaborate with multiple stakeholders to undertake CCA-related activities. As examples, the CCCCC developed the ' $1.5^{\circ}$ to Stay Alive' campaign (CCCCC, 2014, online), and SPC produces a television show that features climate change issues (SPC, 2015b). At its 2015 meeting, the CCCCC's Board of Governors supported moves to strengthen relationships with the private sector and to work more closely with other CARICOM specialised agencies (CCCCC, 2015a, online). All three organisations develop and/or implement CCA-related training programs for stakeholders, with the CCCCC being recognised by the UN Institute of Training and Research as a Centre of Excellence (CARICOM Secretariat, 2011). As part of a pilot project under the PACC Programme, SPREP ran coastal erosion monitoring training for staff from the Samoan Ministry of Natural Resources and Environment (SPREP, 2013b). While the output indicators for all three organisations are generally positive, only SPC and SPREP make their annual work plans and reports publicly available and provide information on the extent to which their adaptation-related objectives are being met-SPC reports annually on how expenditure compared with the budget for the year and SPREP reports on the percentage completion of targets (see e.g. SPC, 2015a).

\section{Discussion}

\subsection{Implications of Results for Regional Climate Adaptation Strategies and Programming}

Overlapping Mandates and "Turf Wars": While neither SPC nor SPREP was established with a specific mandate to address climate change issues, it is now a key component of their work (SPC, 2013; SPREP, 2011). Up to 10 years ago, however, this was not the case-SPC's 2007-2012 corporate plan, for example, included just one four-line paragraph about climate change, noting that it would support SPREP's lead in this area (SPC, 2007). At that time, SPREP's stated climate change objective was to "[i]mprove PICTs' understanding of and strengthen their capacity to respond to climate change, climate variability and sea-level rise" (SPREP, 2006, p. 23); the converging mandates of the two organisations could result in competition for scarce adaptation funding and potentially lead to what has been publicly referred to as a "turf war" (e.g. ABC, 2015, online; Maclellan, 2011, p. 24). In contrast, 
This paper has been accepted for publication in Regional Environmental Change. The full publication may be viewed at: http://dx.doi.org/10.1007/s10113-016-0991-6. Please cite as: Robinson, S. and Gilfillan, D., 2016. Regional organisations and climate change adaptation in small island developing states, Regional Environmental Change, Online first: 1-16. Available at: http://dx.doi.org/10.1007/s10113-016-0991-6 (accessed mmddyyyy).

442

the CCCCC was created specifically to coordinate and manage responses to climate change in the Caribbean (CARICOM Secretariat, 2011). While there are other organisations in the Caribbean such as the Association of Caribbean States and the University of the West Indies that administer climate change projects, they do not have a specific mandate for coordinating climate change responses across the region (see UWI, 2012; ACS, 2012). Organisational effectiveness may be impeded where two or more organisations working within the same region have overlapping mandates.

There are multiple options for resolving the overlap in organisational mandates and thus reducing the likely competition for scarce resources. The two options proposed here are based on work by Linn and Pidufala (2008) and Nolte (2014), which discuss different aspects of regional governance, including regional economic cooperation. One option would be to focus on differentiating mandates in the Pacific, as is the case in the Caribbean. Mandate differentiation would result in either (1) one organisation being wholly responsible for coordinating the regional response to climate change or (2) a fully coordinated approach across relevant organisations working at the regional level. The latter would require a clear delineation of roles within the coordinated response. An alternative to mandate differentiation is for SPREP to be incorporated into SPC as a specialised agency, similar to the CCCCC being a specialised agency of CARICOM. Likewise, Linn and Pidufala (2008) suggested the consolidation of regional organisations, and there have been recent efforts in the Pacific to reduce the number of regional organisations. For example, the Pacific Islands Applied Geoscience Commission (SOPAC) was incorporated into SPC and SPREP under the Regional Institutional Framework Reform with effect from 2011 (SPC - Geoscience Division, 2010). The extent to which these consolidation efforts in the Pacific have improved organisational effectiveness is not yet known.

Regional Organisations as Project/Program Implementers: All three regional organisations researched have implemented adaptation projects/programs. However, our results show that for all three organisations, project/program effectiveness is their weakest area. This is perhaps an issue of scale; a regional organisation directly implementing pilot projects within a community setting is operating from a supranational level through both the national and subnational levels. While this may avoid some of the cross-scale barriers discussed in the literature such as authorisation, and the availability of resources, technology and human capital (e.g. Moser and Ekstrom, 2010), it can introduce problems of its own. With a single project manager based in a regional organisation and being responsible for implementing multiple discrete projects with differing aims and objectives, the varying socio-economic, cultural, spatial and political contexts across and within recipient island countries will limit the successful implementation of the projects. This idea is partially encapsulated in a comment by the PACC Programme Manager: 
This paper has been accepted for publication in Regional Environmental Change. The full publication may be viewed at: http://dx.doi.org/10.1007/s10113-016-0991-6. Please cite as: Robinson, S. and Gilfillan, D., 2016. Regional organisations and climate change adaptation in small island developing states, Regional Environmental Change, Online first: 1-16. Available at: http://dx.doi.org/10.1007/s10113-016-0991-6 (accessed mmddyyyy).

"In an ideal situation, projects follow a cycle of planning, implementation and monitoring, but because of the complex nature of the PACC programme, this has not been always possible. We have had to adjust and adapt to make things work" (SPREP, 2013a, p. 39).

But can this comment be seen as an application of 'adaptive management' i.e. the "process of iteratively planning, implementing, and modifying strategies for managing resources in the face of uncertainty and change" (IPCC, 2014, p. 1758), or as an indictment on poor project/program design? The project documents reviewed often cited the application of 'adaptive management' techniques when project scopes changed, components were dropped and/or original targets were not met. In the case of the PACC Programme, it was used to explain the program not following the 'ideal' project path. In the case of the SPACC Programme in the Caribbean, it was used to explain part of the reason for dropping two of the seven pilot interventions after project inception (see World Bank, 2012). It is possible that the term 'adaptive management' is being used to mask other project/program deficiencies. On the other hand, the PACC Programme Evaluators noted that PICT officials "had not fully identified vulnerabilities nor formulated climate adaptation strategies for a sector or the country; many had produced relatively simple lists of new project concepts", with these lists not constituting "a sound basis for identifying and developing priority actions and projects" (Hunnam et al., 2012, p. 34). This also suggests that critical assessments of "current (baseline) and future conditions, covering climatic, environmental, social, and economic factors" were not carried out (Hunnam et al., 2012, p. 34). At the design phase, proposed adaptation projects must be screened for feasibility and possible maladaptation (see Barnett and O'Neill, 2010). Failing this, project/program managers will continue to cite the application of 'adaptive management' techniques when project scopes are changed, even when the project/program design does not give full consideration to the climate and non-climate-related vulnerabilities as well as to the broader socio-economic, cultural, spatial and political implementation contexts. In addition, while implementation of pilot projects is a way of testing approaches, the variety of factors that influence the success of a project in a particular location may be markedly different in another location, potentially impacting the sustainability of the pilot project methodology.

The challenges of project design and implementation outlined above highlight the need for a debate about whether the regional scale is appropriate for direct implementation of adaptation projects/programs in SIDS. The adaptation projects/programs assessed as part of this study all consisted of multiple pilot projects. We have discussed the challenges of implementing discrete adaptation pilot projects simultaneously across a variety of SIDS. Our results suggest that if regional organisations, working supranationally, continue with direct project implementation, there will be a number of areas that require attention. These areas include (1) developing SMART indicators for ease of 
This paper has been accepted for publication in Regional Environmental Change. The full publication may be viewed at: http://dx.doi.org/10.1007/s10113-016-0991-6. Please cite as: Robinson, S. and Gilfillan, D., 2016. Regional organisations and climate change adaptation in small island developing states, Regional Environmental Change, Online first: 1-16. Available at: http://dx.doi.org/10.1007/s10113-016-0991-6 (accessed mmddyyyy).

511 project/program monitoring and evaluating, (2) strengthening project/program design, and 512 incorporating evidence from previously-implemented projects/programs, (3) ensuring continuity of 513 appropriately qualified project/program staff, (4) ensuring sufficient project funding, including for 514 contingencies, and (5) ensuring projects provide value for money. Strengthening these areas is likely to 515 lead to greater project/program effectiveness. organisations are made here. These are informed by interviewee responses.

The first recommendation is that regional organisations should focus on resolving the "major information deficit issues", noted by one Caribbean official (Interviews, January 2015) (see also Dornan and Newton Cain, 2014):

This view was supported by one Pacific official who noted that regions "need to have access to technological resources such as early warning systems and modelling software" (Interviews, September 2014). SPC and SPREP, working supranationally, are well-placed to deploy such resources throughout the Pacific region.

The second recommendation is for regional organisations to continue to "help countries develop a portfolio of ready-to-finance investment projects" and to improve countries' access to international adaptation financing (Interviews, January 2015). This role, in the Caribbean, has been impeded because:

"One of the things that is very important for regional organisations to lead on would be the issue of the climate models - if we are using the climate models to inform policy direction and project interventions, no single country in our region can do that, so that is something for a regional entity like the CCCCC to enact" (Interviews, January 2015).

The situation in the Pacific is different. Countries such as Samoa, one Pacific civil servant noted, are "swimming out" to attract financing for national adaptation projects, which is helping to relieve the

“... very few countries have been agile enough to move in this direction [...]; in some respects, some are just downright slow and others seem to have little appetite to move in that direction; if we don't, then clearly it's going to come back to haunt us" (Interviews, January 2015).

$$
\text { burden on regional organisations to attract these resources (Interviews, October 2014). Another Pacific }
$$
civil servant noted that countries such as Fiji "know how to play the game" and are able to attract more 
This paper has been accepted for publication in Regional Environmental Change. The full publication may be viewed at: http://dx.doi.org/10.1007/s10113-016-0991-6. Please cite as: Robinson, S. and Gilfillan, D., 2016. Regional organisations and climate change adaptation in small island developing states, Regional Environmental Change, Online first: 1-16. Available at: http://dx.doi.org/10.1007/s10113-016-0991-6 (accessed mmddyyyy).

adaptation financing than other Pacific SIDS that are not as savvy (Interviews, August 2015). These countries that are perceived by other Pacific officials as having the international financing 'know how' could play a role in assisting other less adept countries to pursue required financing. This would, however, raise additional questions regarding the role and continued relevance of regional organisations in coordinating regional responses to climate change across SIDS.

The third recommendation is that regional organisations should prioritise capacity-building for risk reduction within national governments over discrete project implementation, at least over the next few years. As one Caribbean interviewee noted, regional organisations can [and should] lead on "building capacity to reduce our [the region's] exposure to risk" (Interviews, January 2015). This suggestion is similar to a global move, including in the Pacific for the development of joint national action plans that integrate disaster risk reduction with CCA, both at national and regional levels (Nalau et al., 2015). Likewise, the Caribbean is moving towards a comprehensive disaster risk management approach, which is part of a broader sustainable development goal that aims "to strengthen regional, national and community-level capacity for mitigation, management and coordinated response to natural and technological hazards and the effects of climate change" (Collymore, 2011, p. 15). Leading on capacity-building could involve, for example, helping governments to build their skills base. This would support a higher degree of national government ownership over the adaptation process, as per the comment of another Caribbean official that, "shifts in cultural paradigms" and "government buy-in" are "the only way that we will truly adapt to climate change" (Interviews, December 2014). Additionally, the national capacity-building required does not only relate to climate change. A Caribbean official said that the state of national "policy or enabling environments" hampers the extent to which regional organisations can be effective (Interviews, January 2015). The interviewee explained that many Caribbean countries, for example, rank poorly on the World Bank's 'Doing Business Index' because of:

\footnotetext{
“... bureaucratic structures, how long it takes to get things done, the kinds of hoops you have to go through [and that] there is no 'one-stop-shop' type of agency to facilitate the kinds of [adaptation-related] investments necessary" (Interviews, January 2015).
}

Without an appropriate, functioning policy or enabling environment at the national level, there are limits to the adaptation support that regional organisations can provide. 
This paper has been accepted for publication in Regional Environmental Change. The full publication may be viewed at: http://dx.doi.org/10.1007/s10113-016-0991-6. Please cite as: Robinson, S. and Gilfillan, D., 2016. Regional organisations and climate change adaptation in small island developing states, Regional Environmental Change, Online first: 1-16. Available at: http://dx.doi.org/10.1007/s10113-016-0991-6 (accessed mmddyyyy).

This study is not intended as a final assessment of regional organisations coordinating CCA in SIDS; rather, it is a preliminary assessment designed to initiate a debate about what roles regional organisations can most effectively play in supporting adaptation across SIDS. As such, it opens up a number of opportunities for future research, such as:

- Re-applying FAROCCCA to the three case study organisations when more information, particularly for the CCCCC (e.g. annual and audited financial reports), becomes publicly available.

- Assessing the perceptual indicators in FAROCCCA, leading to a more nuanced understanding of regional organisational effectiveness with respect to CCA and SIDS.

- Applying FAROCCCA to organisations working in fields other than CCA.

- Assessing the role that external donors play in influencing regional organisations' actions and decisions around CCA, and also on the nature of adaptation responses in SIDS.

- Exploring the demand-side of adaptation in SIDS, and the factors that drive adaptation processes and actions.

- Determining whether there is a relationship between the size and resources of individual countries and the nature and extent of their engagement with regional organisations in relation to CCA.

\section{Conclusion}

This paper makes three primary contributions to the academic literature. First, it develops FAROCCCA, a qualitative tool for understanding and rating the effectiveness of the regional organisations coordinating regional responses to climate change across SIDS. FAROCCCA has four components, 18 sub-components and 62 indicators, covering areas such as the quality of human, financial and technological resources, the logic, design and adequacy of adaptation projects/programs, and collaboration and advocacy. It is a tool that can be used by regional organisations themselves as well as by independent evaluators and academics. The Framework could also be modified or expanded to suit specific circumstances, for example, to assess regional organisations working in fields other than CCA and SIDS. Second, this cross-regional study into the effectiveness of regional organisations coordinating regional responses to climate change across SIDS is among the first in the academic literature. To date, the literature has focussed on single-country and single-region examinations of adaptation practices and processes in SIDS, often zeroing in on the effectiveness of national governments and community-based organisations. This paper helps to fill the gap relating to adaptation practices and processes across SIDS regions and the effectiveness of action at the supranational level. 
This paper has been accepted for publication in Regional Environmental Change. The full publication may be viewed at: http://dx.doi.org/10.1007/s10113-016-0991-6. Please cite as: Robinson, S. and Gilfillan, D., 2016. Regional organisations and climate change adaptation in small island developing states, Regional Environmental Change, Online first: 1-16. Available at: http://dx.doi.org/10.1007/s10113-016-0991-6 (accessed mmddyyyy).

616 Third, it provides empirical evidence to show that the regional organisations studied are comparatively

617 effective with respect to their CCA-related inputs and outputs but that they are less effective in 618 designing, implementing, monitoring and evaluating adaptation projects/programs. The study 619 recommends that, in addition to differentiating organisational mandates, regional organisations should 620 focus on resolving the major climate-related information deficit issues, helping countries to develop 621 ready-to-finance investment projects, building national-level capacities to adapt, and supporting the creation of an enabling environment for CCA.

\section{Acknowledgements}

The authors contributed equally to this paper. They acknowledge: the Australian Department of Foreign Affairs and Trade and the Fenner School of Environment and Society at The Australian National University for financial support to undertake fieldwork; the Caribbean and Pacific interviewees; A/Prof Jamie Pittock, Dr Tony Weir, Dr Ian Fry, Prof Karen Edyvane, Prof Ian White and the anonymous reviewers for constructive feedback on earlier drafts; Liz Dovey for her insights as well as Daniel Ferris and Tiffany Taylor for editing and proof reading.The authors are responsible for all errors.

\section{References}

ABC, 2015. SPC, SPREP 'turf war' claims are unhelpful: Tukuitonga, Australian Broadcasting Corporation. Available at: http://www.radioaustralia.net.au/international/radio/program/pacific-beat/spc-sprep-turf-warclaims-are-unhelpful-tukuitonga/1319234 (accessed November 20, 2015).

ACS, 2012. About the ACS, Associaton of Caribbean States. Available at: http://www.acsaec.org/index.php?q=about-the-acs (accessed April 16, 2016).

ADB and Commonwealth Secretariat, 2006. Towards a New Pacific Regionalism, Asian Development Bank, Available at: http://www.adb.org/sites/default/files/publication/28797/pacificregionalism-vol2.pdf (accessed April 6, 2016).

Barnett, J. and O'Neill, S., 2010. Maladaptation, Global Environ Chang, 20(2): 211-213. Available at: http://dx.doi.org/10.1016/j.gloenvcha.2009.11.004 (accessed April 29, 2014).

Beattie, A., 2013. Independent Review of the Pacific Plan: The governance of priorities, financing and performance in the delivery of public goods by international and regional membership organisations (Paper prepared for the Pacific Plan Review 2013), Pacific Islands Forum Secretariat Suva, Fiji. Available at: http://www.pacificplanreview.org/resources/uploads/embeds/files/AnthonyBeattie Governan ceFINAL.pdf (accessed August 18, 2015).

Biermann, F. and Bauer, S., 2004. Assessing the effectiveness of intergovernmental organisations in international environmental politics, Global Environ Chang, 14(2): 189-193. Available at: http://dx.doi.org/10.1016/S0959-3780(03)00025-6 (accessed October 31, 2015).

Bishop, M. L., Girvan, N., Shaw, T. M., Mike, S., Mark Kirton, R., Scobie, M., Mohammed, D. and Anatol, M., 2011. Caribbean Regional Integration, University of the West Indies, Port-ofSpain. Available at: http://www19.iadb.org/intal/intalcdi/PE/2011/08559.pdf (accessed April 9, 2916). 
This paper has been accepted for publication in Regional Environmental Change. The full publication may be viewed at: http://dx.doi.org/10.1007/s10113-016-0991-6. Please cite as: Robinson, S. and Gilfillan, D., 2016. Regional organisations and climate change adaptation in small island developing states, Regional Environmental Change, Online first: 1-16. Available at: http://dx.doi.org/10.1007/s10113-016-0991-6 (accessed mmddyyyy).

657

658

659

660

661

662

663

664

665

666

667

668

669

670

671

672

673

674

675

676

677

678

679

680

681

682

683

684

685

686

687

688

689

690

691

692

693

694

695

696

697

698

699

700

701

702

703

704

705

Bryant-Tokalau, J. and Frazer, I., 2006. Redefining the Pacific?: regionalism past, present and future, Ashgate Publishing, Ltd., Hampshire, UK and Burlington, USA.

Button, S. B., Mathieu, J. E. and Zajac, D. M., 1996. Goal Orientation in Organizational Research: A Conceptual and Empirical Foundation, Organizational Behavior and Human Decision Processes, 67(1): 26-48. Available at: http://dx.doi.org/10.1006/obhd.1996.0063 (accessed November 17, 2015).

Byron, J., 2014. A Caribbean Perspective on Regionalism: What Role for CELAC?, Revista Cubana de Economía Internacional, 3: 1-19. Available at: http://www.rcei.uh.cu/index.php/rcei/article/viewFile/26/21 (accessed April 7, 2016).

Cameron, K., Mora, C., Leutscher, T. and Calarco, M., 2011. Effects of Positive Practices on Organizational Effectiveness, The Journal of Applied Behavioral Science, 47(3): 266-308. Available at: http://dx.doi.org/10.1177/0021886310395514 (accessed October 20, 2015).

CARICOM Secretariat, 2011. Caribbean Community Climate Change Centre (CCCCC), Caribbean Community Secretariat. Available at: http://www.caricom.org/jsp/community/ccccc.jsp?menu=community (accessed December 27, 2015).

CCCCC, 2008. Submission from the Caribbean Community Climate Change Centre on its Activities in Climate Modelling, Scenarios and Downscaling United Nations Framework Convention on Climate Change, Bonn. Available at: https://unfccc.int/files/adaptation/sbsta_agenda_item_adaptation/application/pdf/ccccc_april_ 08.pdf (accessed November 30, 2015).

CCCCC, 2012. Delivering Transformational Change 2011-21: Implementing the CARICOM 'Regional Framework for Achieving Development Resilient to Climate Change', Technical Report, Caribbean Community Climate Change Centre, Belmopan. Available at: http://www.gwp.org/Global/GWP-C\%20Files/IP\%20cccc.pdf (accessed November 12, 2015).

CCCCC, 2014. $1.5^{\circ} \mathrm{C}$ Stay Alive - An Education Initiative, Caribbean Climate Blog. Available at: http://caribbeanclimateblog.com/1-5\%CB\%9Ac-stay-alive-an-education-initiative/ (accessed December 4, 2015).

CCCCC, 2015a. 5Cs Concludes Annual Board of Governors Meeting: Expanded partnerships with CARPHA, Deeper Private Sector Partnerships, New Member and Heightened Outreach Announced, Caribbean Community Climate Change Centre. Available at: http://caribbeanclimateblog.com/2015/06/29/5cs-concludes-annual-board-of-governorsmeeting-expanded-partnerships-with-carpha-deeper-private-sector-partnerships-new-memberand-heightened-outreach-announced/ (accessed November 15, 2015).

CCCCC, 2015b. Special Program on Adaptation to Climate Change (SPACC), Caribbean Community Climate Change Centre. Available at: http://www.caribbeanclimate.bz/closed-projects/20072011-special-program-on-adaptation-to-climate-change-spacc.html (accessed October 21, 2015).

Cherian, A., 2007. Linkages between biodiversity conservation and global climate change in small island developing States (SIDS), Natural resources forum, 31(2): 128-131. Available at: http://dx.doi.org/10.1111/j.1477-8947.2007.00138.x (accessed March 29, 2015).

Colley, M., Haworth, A. and Firth, J., 2011. Regional Diagnostic: Climate Change and Development Research Capacities and Regional Priorities in the Caribbean, Caribbean Community Climate Change Centre, Belize. Available at: http://www10.iadb.org/intal/intalcdi/PE/2011/09296.pdf (accessed December 4, 2015).

Collymore, J., 2011. Disaster management in the Caribbean: Perspectives on institutional capacity reform and development, Environmental Hazards, 10(1): 6-22. Available at: http://dx.doi.org/10.3763/ehaz.2011.0002 (accessed April 10, 2016). 
This paper has been accepted for publication in Regional Environmental Change. The full publication may be viewed at: http://dx.doi.org/10.1007/s10113-016-0991-6. Please cite as: Robinson, S. and Gilfillan, D., 2016. Regional organisations and climate change adaptation in small island developing states, Regional Environmental Change, Online first: 1-16. Available at: http://dx.doi.org/10.1007/s10113-016-0991-6 (accessed mmddyyyy).

Connolly, T., Conlon, E. J. and Deutsch, S. J., 1980. Organizational Effectiveness: A MultipleConstituency Approach, The Academy of Management Review, 5(2): 211-217. Available at: http://www.jstor.org/stable/257430 (accessed December 2, 2015).

Daft, R. L., 2012. Organization Theory and Design, South-Western/Cengage Learning, Mason, Ohio.

Dornan, M. and Newton Cain, T., 2014. Regional Service Delivery among Pacific Island Countries: An Assessment, Asia \& the Pacific Policy Studies, 1(3): 541-560. Available at: http://dx.doi.org/10.1002/app5.45 (accessed April 29, 2016).

Etzioni, A., 1960. Two Approaches to Organizational Analysis: A Critique and A Suggestion, Administrative Science Quarterly, 5(2): 257-278. Available at: http://dx.doi.org/10.2307/2390780 (accessed October 2, 2016).

Etzioni, A., 1964. Modern Organizations, Prentice Hall, Englewood Cliffs, New Jersey.

Fry, G., 2004. Whose Oceania? Contending visions of community in Pacific region-building, Department of International Relations, Canberra, Australia. Available at: https://digitalcollections.anu.edu.au/bitstream/1885/42693/2/04-3.pdf (accessed April 9, 2016).

GCCA, SPC and Government of the Republic of the Marshall Islands, 2014. Global Climate Change Alliance: Pacific Small Island States Project Design Document: Protecting Atoll Habitability, Land and Infrastructure in Ailinglaplap, Marshall Islands Global Climate Change Alliance, Secretariat of the Pacific Community and Government of the Republic of the Marshall Islands, Available http://www.pacificclimatechange.net/components/com booklibrary/ebooks/RMI\%20PDD\%2 0-\%20final\%20-\%20version\%20for\%20SPC\%20website.pdf (accessed November 28, 2015).

Girvan, N., 2011. The Caribbean in a Turbulent World, In Inter-American Cooperation at a Crossroads: International Political Economy Series (Eds, Mace, G., Cooper, A. and Shaw, T.) Palgrave Macmillan, Basingstoke, pp. 60-77.

Gupta, J., Termeer, C., Klostermann, J., Meijerink, S., van den Brink, M., Jong, P., Nooteboom, S. and Bergsma, E., 2010. The Adaptive Capacity Wheel: a method to assess the inherent characteristics of institutions to enable the adaptive capacity of society, Environmental Science \& Policy, 13(6): 459-471. Available at: http://dx.doi.org/10.1016/j.envsci.2010.05.006 (accessed September 27, 2015).

Haas, E. B., 1990. When knowledge is power: three models of change in international organizations, Univ of California Press, Berkeley.

Herman, R. D. and Renz, D. O., 2008. Advancing nonprofit organizational effectiveness research and theory: Nine theses, Nonprofit Management and Leadership, 18(4): 399-415. Available at: http://dx.doi.org/10.1002/nml.195 (accessed December 8, 2015).

Hewitson, B. C., Janetos, A. C., Carter, T. R., Giorgi, F., Jones, R. G., Kwon, W. T., Mearns, L. O., Schipper, E. L. F. and van Aalst, M., 2014. Regional context, In Climate Change 2014: Impacts, Adaptation, and Vulnerability. Part B: Regional Aspects. Contribution of Working Group II to the Fifth Assessment Report of the Intergovernmental Panel of Climate Change (Eds, Barros, V. R., Field, C. B., Dokken, D. J., Mastrandrea, M. D., Mach, K. J., Bilir, T. E., Chatterjee, M., Ebi, K. L., Estrada, Y. O., Genova, R. C., Girma, B., Kissel, E. S., Levy, A. N., MacCracken, S., Mastrandrea, P. R. and White, L. L.) Cambridge University Press, Cambridge, United Kingdom and New York, NY, USA, pp. 1133-1197.

Hunnam, P., Kenny, G. and Carpenter, C., 2012. Pacific Adaptation to Climate Change Project: MidTerm Review, Secretariat of the Pacific Regional Environment Programme, United Nations Development Programme and Global Environmental Facility, Apia. Available at: http://www.seachangecop.org/sites/default/files/documents/2012\%2010\%20UNDP\%20\%20PACC MTR\%20Report.pdf (accessed November 28, 2015).

IMF, 2005. Definition of (1) a Currency Union Territory, (2) Regional Organization, and (3) Regional Central Bank Outcome Paper (CUTEG), International Monetary Fund, Washington, D.C. 
This paper has been accepted for publication in Regional Environmental Change. The full publication may be viewed at: http://dx.doi.org/10.1007/s10113-016-0991-6. Please cite as: Robinson, S. and Gilfillan, D., 2016. Regional organisations and climate change adaptation in small island developing states, Regional Environmental Change, Online first: 1-16. Available at: http://dx.doi.org/10.1007/s10113-016-0991-6 (accessed mmddyyyy).

Available at: http://www.imf.org/external/np/sta/bop/pdf/fp6.pdf (accessed December 3, 2015).

IPCC, 2007. Climate Change 2007: Impacts, Adaptation and Vulnerability. Contribution of Working Group II to the Fourth Assessment Report of the Intergovernmental Panel on Climate Change, Cambridge University Press, Cambridge, UK.

IPCC, 2014. Annex II: Glossary, In Climate Change 2014: Impacts, Adaptation, and Vulnerability. Part B: Regional Aspects. Contribution of Working Group II to the Fifth Assessment Report of the Intergovernmental Panel on Climate Change (Eds, Barros, V. R., Field, C. B., Dokken, D. J., Mastrandrea, M. D., Mach, K. J., Bilir, T. E., Chatterjee, M., Ebi, K. L., Estrada, Y. O., Genova, R. C., Girma, B., Kissel, E. S., Levy, A. N., MacCracken, S., Mastrandrea, P. R. and White, L. L.) Cambridge University Press, Cambridge and New York, pp. 1757-1776.

Iwu, C. G., Kapondoro, L., Twum-Darko, M. and Tengeh, R., 2015. Determinants of Sustainability and Organisational Effectiveness in Non-Profit Organisations, Sustainability, 7: 9560-9573. Available at: http://dx.doi.org/10.3390/su7079560 (accessed October 19, 2015).

Linn, J. F. and Pidufala, O., 2008. The experience with regional economic cooperation organizations: Lessons for Central Asia, Wolfensohn Center for Development, Washington DC, US. Available at: http://dx.doi.org/10.2139/ssrn.1301631 (accessed April 16, 2016 ).

Lockwood, M., Davidson, J., Curtis, A., Stratford, E. and Griffith, R., 2010. Governance Principles for Natural Resource Management, Society \& Natural Resources, 23(10): 986-1001. Available at: http://dx.doi.org/10.1080/08941920802178214 (accessed December 7, 2015).

Maclellan, N., 2011. Analysis: improving access to climate financing in the Pacific Islands, Lowy Institute for International Policy, Sydney, Australia. Available at: http://www.lowyinstitute.org/files/pubfiles/Maclellan,_Improving_access_to_climate_financi ng_web.pdf (accessed April 3, 2016).

McDavid, J. C., Huse, I. and Hawthorn, L. R. L., 2013. Program Evaluation and Performance Measurement: An Introduction to Practice, SAGE, Los Angeles.

Miller, D. C. and Salkind, N. J., 2002. Handbook of Research Design and Social Measurement, SAGE Publications, Inc., Thousand Oaks, California.

Mitchell, R. B., 2008. Evaluating the performance of environmental institutions: What to evaluate and how to evaluate it?, In Institutions and environmental change: Principal findings, applications, and research frontiers (Eds, Young, O. R., King, L. A. and Schroeder, H.) Massachusetts Institute of Technology, Cambridge, Massachusetts and London, England, pp. 79-114.

Moser, S. C. and Ekstrom, J. A., 2010. A framework to diagnose barriers to climate change adaptation, Proceedings of the National Academy of Sciences, 107(51): 22026-22031. Available at: http://dx.doi.orgdoi/10.1073/pnas.1007887107 (accessed July 5, 2015).

Nalau, J., Handmer, J., Dalesa, M., Foster, H., Edwards, J., Kauhiona, H., Yates, L. and Welegtabit, S., 2015. The practice of integrating adaptation and disaster risk reduction in the south-west Pacific, Climate and Development. Available at: http://dx.doi.org/10.1080/17565529.2015.1064809 (accessed April 17, 2016).

Nolte, D., 2014. Latin America's New Regional Architecture: A Cooperative or Segmented Regional Governance Complex?, Robert Schuman Centre for Advanced Studies Research Paper No. RSCAS, 2014/89. Available at: http://dx.doi.org/10.2139/ssrn.2494843 (accessed December 5, 2015).

Nurse, L. A., McLean, R. F., Agard, J., Briguglio, L. P., Duvat-Magnan, V., Pelesikoti, N., Tompkins, E. and Webb, A., 2014. Small islands, In Climate Change 2014: Impacts, Adaptation, and Vulnerability. Part B: Regional Aspects. Contribution of Working Group II to the Fifth Assessment Report of the Intergovernmental Panel of Climate Change (Eds, Barros, V. R., Field, C. B., Dokken, D. J., Mastrandrea, M. D., Mach, K. J., Bilir, T. E., Chatterjee, M., Ebi, K. L., Estrada, Y. O., Genova, R. C., Girma, B., Kissel, E. S., Levy, A. N., MacCracken, S., Mastrandrea, P. R. and White, L. L.) Cambridge University Press, Cambridge and New York, pp. 1613-1654. 
This paper has been accepted for publication in Regional Environmental Change. The full publication may be viewed at: http://dx.doi.org/10.1007/s10113-016-0991-6. Please cite as: Robinson, S. and Gilfillan, D., 2016. Regional organisations and climate change adaptation in small island developing states, Regional Environmental Change, Online first: 1-16. Available at: http://dx.doi.org/10.1007/s10113-016-0991-6 (accessed mmddyyyy).

807

808

809

810

811

812

813

814

815

816

817

818

819

820

821

822

823

824

825

826

827

828

829

830

831

832

833

834

835

836

837

838

839

840

841

842

843

844

845

846

847

848

849

850

851

852

853

854

855

856

857

Oberlack, C. and Neumärker, B., 2013. A Diagnostic Approach to the Institutional Analysis of Climate Adaptation, University of Freiburg, Freiburg, Germany. Available at: https://www.wipo.unifreiburg.de/dateien/research/cen-papers/CENpaper2013 01 (accessed April 11, 2014).

Parhizgari, A. M. and Ronald Gilbert, G., 2004. Measures of organizational effectiveness: private and public sector performance, Omega, 32(3): 221-229. Available at: http://dx.doi.org/10.1016/j.omega.2003.11.002 (accessed October 20, 2015).

PIF Secretariat, 2014. The Framework for Pacific Regionalism, Pacific Islands Forum Secretariat, Suva. Available at: http://www.adb.org/sites/default/files/linked-documents/pacific-robp-20152017-sd.pdf (accessed April 16, 2016).

Quinn, R. E. and Rohrbaugh, J., 1983. A Spatial Model of Effectiveness Criteria: Towards a Competing Values Approach to Organizational Analysis, Manage Sci, 29(3): 363-377. Available at: http://dx.doi.org/10.2307/2631061 (accessed October 25, 2015).

Sowa, J. E., Selden, S. C. and Sandfort, J. R., 2004. No Longer Unmeasurable? A Multidimensional Integrated Model of Nonprofit Organizational Effectiveness, Nonprof Volunt Sec Q, 33(4): 711728. Available at: http://dx.doi.org/10.1177/0899764004269146 (accessed October 19, 2015).

SPC - Geoscience Division, 2010. Regional Institutional Framework (RIF) Reform transfers SOPAC functions into SPC and SPREP, Available at: http://gsd.spc.int/media-releases/1-latestnews/86-regional-institutional-framework-rif-reform-transfers-sopac-functions-into-spc-andsprep (accessed December 28, 2015).

SPC, 1947. Canberra agreement: Agreement establishing the South Pacific Commission, Secretariat of the Pacific Community, Canberra, Australia. Available at: http://www.spc.int/images/stories/About_SPC/Canberra-Agreement.pdf (accessed December 4, 2015).

SPC, 2007. Secretariat of the Pacific Community (SPC) Corporate Plan (2007-2012), Noumea, New Caledonia. Available at: http://www.spc.int/DigitalLibrary/Doc/SPC/Meetings/CRGA/CRGA_36/CRGA_36_Paper_4 _3_1_Corporate_Plan_2007_12_E.pdf (accessed December 3, 2015).

SPC, 2011a. Forty-First Meeting of the Committee of Representatives of Governments and Administrations: Agenda Item 8.1 - Directorate of Operations and Management, Secretariat of the Pacific Community, Available at: http://www.spc.int/DigitalLibrary/Doc/SPC/Meetings/CRGA/CRGA 41/CRGA 41 Paper 8 1 Directorate of Operations and Management.pdf (accessed November 29, 2015).

SPC, 2011b. Global Climate Change Alliance: PSIS - About the Project, Secretariat of the Pacific Community. Available at: http://www.spc.int/en/our-work/climate-change/gcca.html (accessed December 16, 2015).

SPC, 2012. Global Climate Change Alliance: Pacific Small Island States, Secretariat of the Pacific Community, Available at: http://www.spc.int/images/climate-change/brief2.pdf (accessed November 2, 2015).

SPC, 2013. Corporate Strategic Plan (2013-2015), Secretariat of the Pacific Community, Noumea, New Caledonia. Available at: http://www.spc.int/images/publications/en/Corporate/corporateplan.pdf (accessed November 2, 2015).

SPC, 2014a. Forty-Fourth Meeting of the Committee of Representatives of Governments and Administrations (Noumea, New Caledonia, 4-7 November 2014) Agenda Item 7: Operations and Management Directorate Report Paper 7.4 - Reports on Human Resources: Staff Development and Retention, Secretariat of the Pacific Community, Noumea, New Caledonia. Available

at: http://www.spc.int/DigitalLibrary/Doc/SPC/Meetings/CRGA/CRGA_44/CRGA_44_Paper_7 4 Reports on Human Resources Staff Development and Retention E.pdf (accessed December 3, 2015).

SPC, 2014b. Global Climate Change Alliance: Pacific Small Island States Project: Progress Report for Period 1 January - 30 June 2014, Secretariat of the Pacific Community, Available at: 
This paper has been accepted for publication in Regional Environmental Change. The full publication may be viewed at: http://dx.doi.org/10.1007/s10113-016-0991-6. Please cite as: Robinson, S. and Gilfillan, D., 2016. Regional organisations and climate change adaptation in small island developing states, Regional Environmental Change, Online first: 1-16. Available at: http://dx.doi.org/10.1007/s10113-016-0991-6 (accessed mmddyyyy).

http://www.pacificclimatechange.net/index.php/eresources/documents?task=view\&id=1245\& catid $=245$ (accessed November 23, 2015).

SPC, 2014c. SPC Annual report 2013, Secretariat of the Pacific Community, Noumea, New Caledonia. Available http://www.spc.int/DigitalLibrary/Doc/SPC/Annual Reports/en annual report 2013.pdf (accessed November 8, 2015).

SPC, 2015a. Forty - Fifth Meeting Of The Committee Of Representatives Of Governments And Administrations ( Alofi, Niue, 31 October - 2 November 2015 ): Agenda Item 9.3: 2015 Revised Budget And 2016 Proposed Budget Secretariat of the Pacific Community, Available at:

http://www.spc.int/crga/sites/default/files/crga_papers/CRGA\%2045\%20Paper\%209.3\%20\%20Revised\%202015\%20Budget\%20-\%202016\%20Budget.pdf (accessed November 29, 2015).

SPC, 2015b. More TV stations to air The Pacific Way show, Secretariat of the Pacific Community. Available at: http://www.spc.int/en/media-releases/2159-more-tv-stations-to-air-the-pacificway-show.html (accessed November 29, 2015).

SPREP, 2006. SPREP Approved Work Programme and Budget for 2007 and Indicative Budgets for 2008 and 2009, Apia, Samoa. Available at: https://www.sprep.org/attachments/Publications/AWPB2007.pdf (accessed December 28, 2015).

SPREP, 2011. Pacific Regional Environment Programme Strategic Plan 2011 - 2015, Secretariat of the Pacific Regional Environment Programme, Apia, Samoa. Available at: https://www.sprep.org/att/publication/000921_SPREPStrategicPlan2011_2015.pdf (accessed November 24, 2015).

SPREP, 2013a. Adapting to Climate Change in the Pacific: The PACC Programme, Secretariat of the Pacific Regional Environment Programme, Apia, Samoa. Available at: https://www.sprep.org/attachments/Publications/CC/PACC_Programme.pdf (accessed December 3, 2015).

SPREP, 2013b. Annual Report 2013 - Secretariat of the Pacific Regional Environment Program, Secretariat of the Pacific Regional Environment Program, Apia, Samoa. Available at: http://www.sprep.org/attachments/Publications/Corporate Documents/AnnRep2013.pdf (accessed September 15, 2015).

SPREP, 2014a. About the PACC Programme, Secretariat of the Pacific Regional Environment Programme. Available at: https://www.sprep.org/pacc (accessed November 22, 2015).

SPREP, 2014b. Annual Report 2014, Secretariat of the Pacific Regional Environment Programme, Apia, Samoa. Available at: https://www.sprep.org/publications/sprep-annual-report-2014 (accessed August 20, 2015).

SPREP, 2014c. Governance, Secretariat of the Pacific Regional Environmental Programme. Available at: https://www.sprep.org/Legal/agreement-establishing-sprep (accessed December 15, 2015).

SPREP, 2015a. PACC Demonstration Guide: Piloting climate change adaptation in food production and food security on low-lying atolls of Solomon Islands, Secretariat of the Pacific Regional Environment Programme, Available at: http://www.sprep.org/attachments/Publications/CC/PACCTechRep19.pdf Iaccessed November 27, 2015).

SPREP, 2015b. Secretariat of the Pacific Regional Environment Programme: Financial Statements for the Year Ended 31 December 2014 Secretariat of the Pacific Regional Environment Programme, Available at: https://www.sprep.org/attachments/2015SM26/official/WP 5.3 Att 1.rev.1 _Audited_Annual_Accounts_2014.pdf (accessed December 3, 2015). 
This paper has been accepted for publication in Regional Environmental Change. The full publication may be viewed at: http://dx.doi.org/10.1007/s10113-016-0991-6. Please cite as: Robinson, S. and Gilfillan, D., 2016. Regional organisations and climate change adaptation in small island developing states, Regional Environmental Change, Online first: 1-16. Available at: http://dx.doi.org/10.1007/s10113-016-0991-6 (accessed mmddyyyy).

907

908

909

910

911

912

913

914

915

916

917

918

919

920

921

922

923

924

925

926

927

928

929

930

931

932

933

934

935

936

937

938

939

940

941

942

943

944

945

946

947

948

949

950

951

Tarte, S., 2014. Regionalism and Changing Regional Order in the Pacific Islands, Asia \& the Pacific Policy Studies, 1(2): 312-324. Available at: http://dx.doi.org/10.1002/app5.27 (accessed December 10, 2015).

Taylor, C. M., Cornelius, C. J. and Colvin, K., 2014. Visionary leadership and its relationship to organizational effectiveness, Leadership \& Organization Development Journal, 35(6): 566583. Available at: http://dx.doi.org/10.1108/LODJ-10-2012-0130 (accessed October 20, 2015).

Trotz, U., n.d. Ulric Trotz, Ph.D.: Science Advisor, Caribbean Community Climate Change Centre, Belize, Columbia University. Available at: http://ffs.ei.columbia.edu/sitefiles/file/Trotz_bio.pdf (accessed December 1, 2015).

UN-OHRLLS, 2015a. About SIDS: Country Profiles, United Nations. Available at: http://unohrlls.org/about-sids/country-profiles/ (accessed June 18, 2015).

UN-OHRLLS, 2015b. Small Island Developing States Membership in Regional/Sub-Regional Organizations, United Nations Office of the High Representative for the Least Developed Countries, Landlocked Developing Countries and the Small Island Developing States. Available at: http://unohrlls.org/about-sids/regional-organizations/ (accessed September 2, 2015).

UWI, 2012. About the UWI, University of the West Indies. Available at: https://www.uwi.edu/history.asp (accessed April 16, 2016).

Weiss, C. H., 2005. Evaluation Research: Methods for Assessing Program Effectiveness, Prentice-Hall Inc., Englewood Cliffs, New Jersey.

Wolfe, R. A. and Putler, D. S., 2002. How Tight Are the Ties that Bind Stakeholder Groups?, Organization Science, 13(1): 64-80. Available at: http://dx.doi.org/10.1287/orsc.13.1.64.544 (accessed December 13, 2015).

World Bank, 2012. Implementation Completion and Results Report (TF-56744) on a Grant in the Amount of US\$ 2.1 Million to the Commonwealth of Dominica, St. Lucia, and St. Vincent and the Grenadines through the Caribbean Community Climate Change Centre (CCCCC) for the Implementation of Adaptation Measures in Coastal Zones Project, Implementation Completion and Results Report, World Bank, Washington, D.C. Available at: http://www.thegef.org/gef/sites/thegef.org/files/gef_prj_docs/GEFProjectDocuments/MandE/ EO TEs FY13/WorldBank TEs APR2013/2552 WB TE P090731-ICR Caribbean.pdf (accessed November 20, 2015).

World Economic Forum, 2014. Effective Leadership in International Organizations, World Economic Forum, Geneva. Available at: http://www3.weforum.org/docs/WEF_Effective_Leadership_International_Organizations_rep ort.pdf (accessed October 23, 2015).

Young, O. R., 2011. Effectiveness of international environmental regimes: Existing knowledge, cuttingedge themes, and research strategies, Proc. Natl. Acad. Sci., 108(50): 19853-19860. Available at: http://dx.doi.org/10.1073/pnas.1111690108 (accessed October 24, 2015).

Yukl, G., 2008. How leaders influence organizational effectiveness, Leadership Quart, 19(6): 708-722. Available at: http://dx.doi.org/10.1016/j.leaqua.2008.09.008 (accessed October 20, 2015).

Zyck, S., 2013. Regional organisations and humanitarian action, HPG working paper, Available at: http://www.odi.org.uk/sites/odi.org.uk/files/odi-assets/publications-opinionfiles/8733.pdf (accessed December 26, 2014). 


\section{APPENDICES}

\section{Regional Organisations and Climate Change Adaptation in Small Island Developing States}

Stacy-ann Robinson ${ }^{1}$ and Daniel Gilfillan ${ }^{2 *}$

${ }^{1}$ Fenner School of Environment and Society, The Australian National University, 48 Linnaeus Way, Acton, ACT 2601, Australia | Tel: +61 (0) 261970017 | Email: stacy-ann.robinson@anu.edu.au

${ }^{2}$ Fenner School of Environment and Society, The Australian National University, 48 Linnaeus Way, Acton, ACT 2601, Australia | Tel: +61 (0) 261970017 | Email: daniel.gilfillan@anu.edu.au

*Corresponding author

List of Appendices

Appendix 1: Theoretical Framework 2

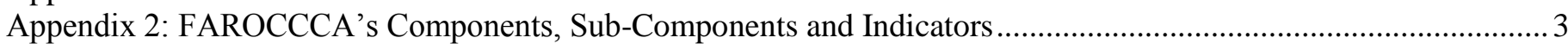

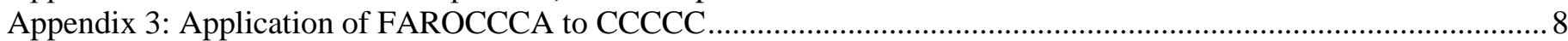

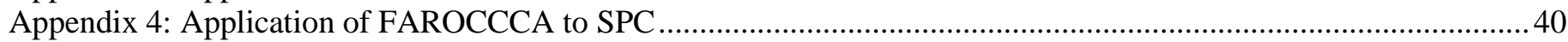

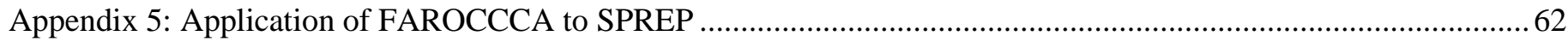

\section{$\underline{\text { List of References }}$}

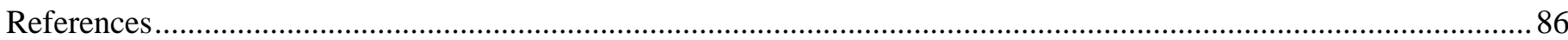




\section{Appendix 1: Theoretical Framework}

There are many theoretical approaches that could be taken to this study, including regionalism and neoregionalism. These were excluded primarily because of their: (1) emphasis on studying how regions are formed and how they function, and (2) functional definition of regions based on economic, environmental and cultural factors (see Väyrynen, 2003).

In contrast, this study focusses on geographically-defined regions and how the regional organisations within them function, particularly with respect to climate change adaptation. As such, the research is primarily shaped by modern organisation theory with elements of neo-functionalism. Modern organisation theory recognises that individuals, processes and systems work together to achieve desired objectives (Hicks and Gullet, 1975); it interprets organisations as adaptive, descriptive and dynamic processes of interaction with many dimensions and motivations (Asopa and Beye, 1997). Aspects of the systems, contingency and socio-technical approaches to modern organisation theory are incorporated in this research. The systems approach emphasises the organisational linking mechanisms and processes (e.g. decision-making and communication), components (e.g. individuals and physical environment), as well as organisational goals (Asopa and Beye, 1997). The contingency approach encourages consideration of the political, socio-economic, cultural, legal and technical environment in which the organisation operates as well as performance optimisation through appropriate organisational relationships (Asopa and Beye, 1997). The socio-technical approach examines the techniques and knowledge that support staff to produce valuable goods and services for wider use (Asopa and Beye, 1997). Neo-functionalism recognises the independent role of organisations (Schmitter, 2003). Non-state actors, such as the secretariats of regional organisations and individuals, work together at the regional level to achieve aggregated interests (see e.g. Ludlow, 2006). From this perspective, Member States establish a regional organisation, set its initial mandate and play a role in determining its operational agenda, a role which generally diminishes over time as authority is gradually devolved to the organisation itself (Schmitter, 2003). These theoretical underpinnings are strengths of this paper. Organisation theory offers an explicit recognition of the complexities that result from having multiple organisations, processes, individuals and operating environments with differing goals and motivations working towards desired outcomes. Its neo-functional elements allow the authors to take an integrated view of each organisation. Both theories shape the authors' ontological view that transformational improvement of regional organisations and systems is possible, making an academic inquiry into regional approaches to climate change adaptation a worthwhile endeavour. 


\section{LEGEND}

Perceptual indicator or indicator not rated in this paper

\begin{tabular}{|c|c|c|}
\hline SUB-COMPONENT & INDICATOR & $\begin{array}{l}\text { EXAMPLE OF SUPPORT } \\
\text { IN THE LITERATURE }\end{array}$ \\
\hline & 1. Input Effectiveness & \\
\hline \multirow[t]{4}{*}{ 1. Goals } & $\begin{array}{l}\text { 1. Climate change adaptation was an initial goal of the } \\
\text { organisation. }\end{array}$ & \multirow[t]{4}{*}{$\begin{array}{l}\text { Biermann and Bauer (2004); Quinn and Rohrbaugh } \\
\text { (1983); Sowa et al. (2004); Young (2011) }\end{array}$} \\
\hline & $\begin{array}{l}\text { 2. Climate change adaptation is a current goal of the } \\
\text { organisation. }\end{array}$ & \\
\hline & $\begin{array}{l}\text { 3. The current strategic plan contains specific climate } \\
\text { change adaptation objectives. }\end{array}$ & \\
\hline & $\begin{array}{l}\text { 4. There is no other regional organisation with similar } \\
\text { climate change adaptation goals. }\end{array}$ & \\
\hline \multirow[t]{7}{*}{ 2. Governance and leadership } & $\begin{array}{l}\text { 1. The Board provides visionary leadership and strategic } \\
\text { direction. }\end{array}$ & \multirow{7}{*}{$\begin{array}{l}\text { Oberlack and Neumärker (2013); Renz and Herman } \\
\text { (2002); Sowa et al. (2004); Taylor et al. (2014); World } \\
\text { Economic Forum (2014); Yukl (2008) }\end{array}$} \\
\hline & $\begin{array}{l}\text { 2. The organisation evaluates organisational performance at } \\
\text { least annually. }\end{array}$ & \\
\hline & $\begin{array}{l}\text { 3. Executive management (can also include members of the } \\
\text { Board/Governing Body) decision-making is done by } \\
\text { consensus or majority vote. }\end{array}$ & \\
\hline & $\begin{array}{l}\text { 4. Executive management staff (can also include members } \\
\text { of the Board/Governing Body) are qualified and/or } \\
\text { equipped to achieve the goals of the organisation. }\end{array}$ & \\
\hline & $\begin{array}{l}\text { 5. Executive management staff disclose potential conflicts } \\
\text { of interest. }\end{array}$ & \\
\hline & 6. The organisation attracts, retains and develops talent. & \\
\hline & $\begin{array}{l}\text { 7. Leaders create a dynamic organisational culture, making } \\
\text { the organisation a desirable place to work. }\end{array}$ & \\
\hline \multirow[t]{4}{*}{ 3. Resources } & $\begin{array}{l}\text { 1. There are staff members exclusively dedicated to climate } \\
\text { change adaptation. }\end{array}$ & \multirow{4}{*}{$\begin{array}{l}\text { Abd Rahman et al. (2013); Biermann and Bauer } \\
\text { (2004); Daft (2012); McDavid et al. (2013); Oberlack } \\
\text { and Neumärker (2013); Sowa et al. (2004); Wolfe and } \\
\text { Putler (2002) }\end{array}$} \\
\hline & $\begin{array}{l}\text { 2. Staff are qualified and have experience in climate change } \\
\text { adaptation. }\end{array}$ & \\
\hline & $\begin{array}{l}\text { 3. Staff are qualified and have experience in } \\
\text { project/program management. }\end{array}$ & \\
\hline & 4. Staff participate in ongoing training programs. & \\
\hline
\end{tabular}




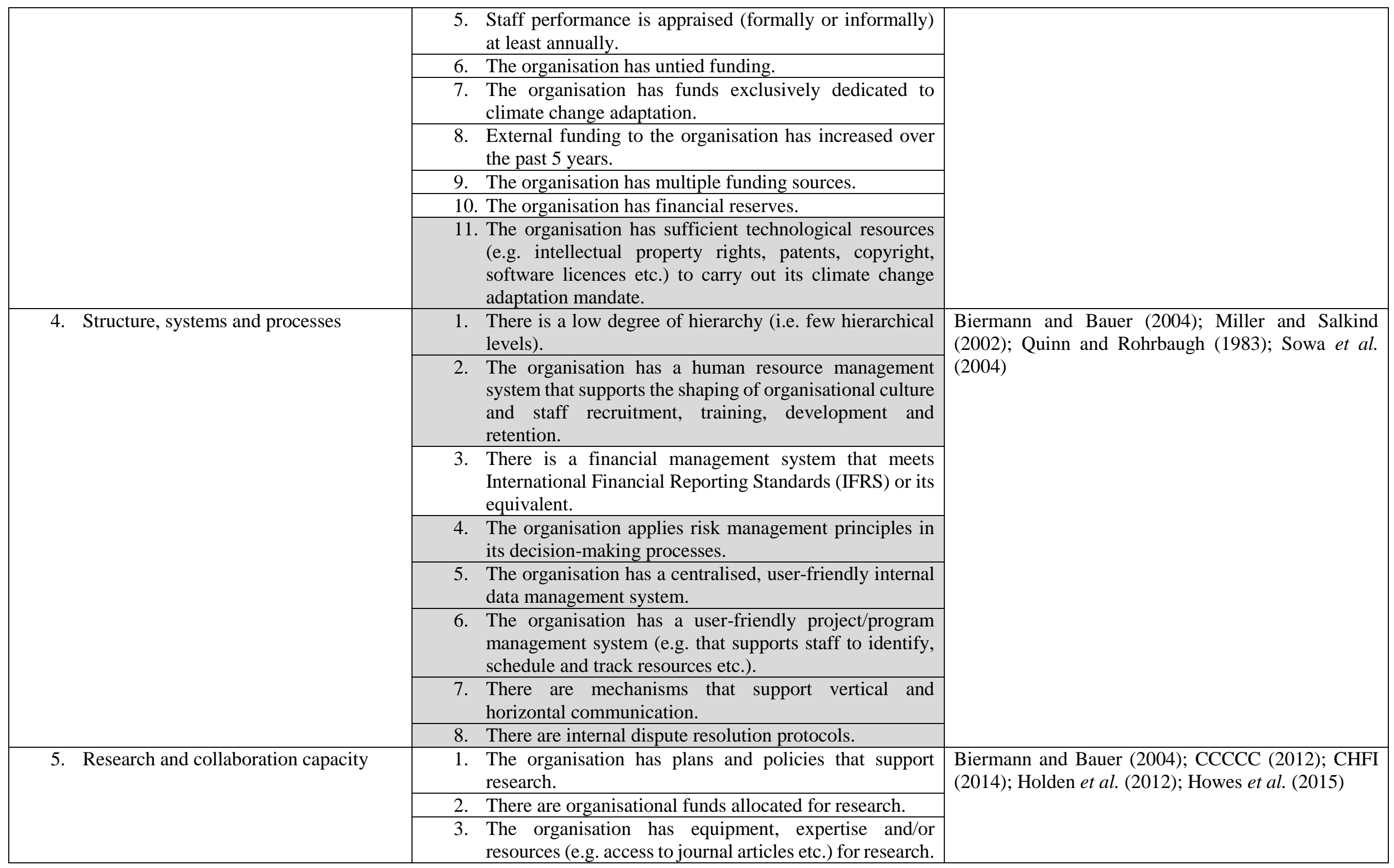




\begin{tabular}{|c|c|c|}
\hline & $\begin{array}{l}\text { 4. The organisation's current strategic plan (or a similar } \\
\text { document) outlines plans for collaboration with multiple } \\
\text { stakeholders on adaptation-related initiatives. }\end{array}$ & \\
\hline & 2. Project/Program Effectiveness & \\
\hline \multirow[t]{6}{*}{ 1. Needs and goals } & $\begin{array}{l}\text { 1. The project documents contain evidence that the } \\
\text { project/program fills an existing need with relation to } \\
\text { climate change adaptation. }\end{array}$ & \multirow[t]{6}{*}{$\begin{array}{l}\text { McDavid et al. (2013); Underdal (2010); Weiss } \\
\text { (2005) }\end{array}$} \\
\hline & $\begin{array}{l}\text { 2. The project/program's adaptation components could be } \\
\text { considered "transformational' (i.e. the project/program } \\
\text { focusses on "larger, more profound system changes" and } \\
\text { requires a "paradigm shift" in the way it is framed and } \\
\text { implemented). }\end{array}$ & \\
\hline & $\begin{array}{l}\text { 3. Climate change adaptation is a goal of the } \\
\text { project/program. }\end{array}$ & \\
\hline & $\begin{array}{l}\text { 4. The project/program's goals reflect the long-range } \\
\text { impacts of climate change. }\end{array}$ & \\
\hline & $\begin{array}{l}\text { 5. The project/program's objectives relating to climate } \\
\text { change adaptation are specific, measurable, achievable, } \\
\text { realistic and time-bound (SMART). }\end{array}$ & \\
\hline & $\begin{array}{l}\text { 6. Member Countries were involved in developing the } \\
\text { climate change adaptation components of the } \\
\text { project/program. }\end{array}$ & \\
\hline \multirow[t]{2}{*}{ 2. Scope } & $\begin{array}{l}\text { 1. The project/program addresses multiple climate or } \\
\text { climate-induced vulnerabilities (e.g. vulnerability to sea- } \\
\text { level rise, increased sea surface and air temperature, } \\
\text { changing rainfall patterns etc.). }\end{array}$ & \multirow[t]{2}{*}{ Robinson (2015); Weiss (2005) } \\
\hline & $\begin{array}{l}\text { 2. The project/program addresses multiple non-climate- } \\
\text { induced vulnerabilities (e.g. poverty, deforestation etc.). }\end{array}$ & \\
\hline \multirow[t]{2}{*}{ 3. Logic, design and adequacy } & $\begin{array}{l}\text { 1. The logic/design of the project/program's climate change } \\
\text { adaptation components is evidence-based, in the context } \\
\text { of SIDS. }\end{array}$ & \multirow[t]{2}{*}{$\begin{array}{l}\text { Biermann and Bauer (2004); Galaz et al. (2008); } \\
\text { McDavid et al. (2013) }\end{array}$} \\
\hline & $\begin{array}{l}\text { 2. The project documents contain evidence that the } \\
\text { logic/design of the project/program's climate change } \\
\text { adaptation components is an effective means to achieve } \\
\text { its objectives. }\end{array}$ & \\
\hline 4. Resources & $\begin{array}{l}\text { 1. Staff members are assigned exclusively to the } \\
\text { project/program. }\end{array}$ & $\begin{array}{l}\text { Daft (2012); McDavid et al. (2013); Wolfe and Putler } \\
\text { (2002) }\end{array}$ \\
\hline
\end{tabular}




\begin{tabular}{|c|c|c|}
\hline & $\begin{array}{l}\text { 2. The project/program team includes staff members with } \\
\text { qualifications and experience in climate change } \\
\text { adaptation. }\end{array}$ & \\
\hline & $\begin{array}{l}\text { 3. The project/program team includes staff members with } \\
\text { qualifications and experience in project/program } \\
\text { management. }\end{array}$ & \\
\hline & $\begin{array}{l}\text { 4. The project documents contain evidence that there are } \\
\text { sufficient staff members to achieve the project/program } \\
\text { objectives. }\end{array}$ & \\
\hline & $\begin{array}{l}\text { 5. The project documents contain evidence that there is } \\
\text { sufficient funding for the project/program's climate } \\
\text { change adaptation components. }\end{array}$ & \\
\hline 5. Technical efficiency & $\begin{array}{l}\text { 1. The project documents contain evidence that the } \\
\text { project/program provides value for money (cost vs. } \\
\text { outputs). }\end{array}$ & McDavid et al. (2013) \\
\hline 6. Implementation & $\begin{array}{l}\text { 1. The project/program's climate change adaptation } \\
\text { components are implemented, as proposed. }\end{array}$ & McDavid et al. (2013) \\
\hline 7. Monitoring and evaluation & $\begin{array}{l}\text { 1. The project/program is internally monitored and } \\
\text { evaluated. }\end{array}$ & McDavid et al. (2013); Yukl (2008) \\
\hline & $\begin{array}{l}\text { 2. The project/program is externally monitored and } \\
\text { evaluated. }\end{array}$ & \\
\hline 8. Sustainability & 1. There are sustained outputs from the project/program. & CCCCC (2012); PIF Secretariat (2014) \\
\hline & 3. Output Effectiveness & \\
\hline 1. Goal attainment & $\begin{array}{l}\text { 1. There is evidence in the most recent annual report or } \\
\text { evaluation that the climate change adaptation-related } \\
\text { objectives of the organisation are being achieved. }\end{array}$ & $\begin{array}{l}\text { Button et al. (1996); Etzioni (1960); Etzioni (1964); } \\
\text { Sowa et al. (2004) }\end{array}$ \\
\hline 2. Research and knowledge management & $\begin{array}{l}\text { 1. The organisation produces and/or publishes research that } \\
\text { is relevant to climate change adaptation at least annually. }\end{array}$ & $\begin{array}{l}\text { CCCCC (2012); PIF Secretariat (2014); also based on } \\
\text { Interviews (August 2014-August 2015) }\end{array}$ \\
\hline & $\begin{array}{l}\text { 2. The organisation makes climate change adaptation- } \\
\text { relevant research publicly available. }\end{array}$ & \\
\hline 3. Collaboration and advocacy & $\begin{array}{l}\text { 1. There is evidence that the organisation collaborates with } \\
\text { multiple stakeholders to undertake climate change } \\
\text { adaptation-related activities. }\end{array}$ & $\begin{array}{l}\text { CCCCC (2012); Connolly et al. (1980); PIF } \\
\text { Secretariat (2014); also based on Interviews (August } \\
\text { 2014-August 2015) }\end{array}$ \\
\hline & $\begin{array}{l}\text { 2. The organisation advocates for political, financial and/or } \\
\text { other climate change support for its Member Countries in } \\
\text { various fora at different scales. }\end{array}$ & \\
\hline 4. Education and training & $\begin{array}{l}\text { 1. The organisation undertakes climate change adaptation } \\
\text { stakeholder and/or public awareness activities. }\end{array}$ & $\begin{array}{l}\text { CCCCC (2012); also based on Interviews (August } \\
\text { 2014-August 2015) }\end{array}$ \\
\hline
\end{tabular}




\begin{tabular}{|c|c|c|}
\hline & $\begin{array}{l}\text { 2. The organisation develops and/or implements training } \\
\text { programs for stakeholders in issues related to climate } \\
\text { change adaptation. }\end{array}$ & \\
\hline 5. Specialised advisory services & $\begin{array}{l}\text { 1. The organisation provides specialised climate change } \\
\text { adaptation-related advice to Member Countries and/or } \\
\text { other stakeholders. }\end{array}$ & $\begin{array}{l}\text { CCCCC (2012); also based on Interviews (August } \\
\text { 2014-August 2015) }\end{array}$ \\
\hline & 4. Outcome Effectiveness & \\
\hline
\end{tabular}

Appendix 2: FAROCCCA's Components, Sub-Components and Indicators (cont'd) 
Appendix 3: Application of FAROCCCA to CCCCC

\begin{tabular}{|c|l|}
\hline \multicolumn{2}{|c|}{ RATING SYSTEM } \\
\hline $\boldsymbol{\otimes}$ & No \\
\hline$\diamond$ & To some extent \\
\hline$\square$ & Yes \\
\hline$(\mathrm{NE})$ & No evidence \\
\hline & Perceptual indicator or indicator not rated in this paper \\
\hline
\end{tabular}

\begin{tabular}{|c|c|c|c|}
\hline SUB-COMPONENT & INDICATOR & EVIDENCE & RATING \\
\hline \multirow{3}{*}{ 1. Goals } & & 1. Input Effectiveness & \\
\hline & $\begin{array}{l}\text { 2. Climate change adaptation was } \\
\text { an initial goal of the organisation. }\end{array}$ & $\begin{array}{l}\text { The Agreement Establishing The Caribbean Community Climate Change Centre } \\
\text { (CCCCC) (2002) states that, "Affirming that responses to climate change should be } \\
\text { co-ordinated with social and economic development in an integrated manner with a } \\
\text { view to avoiding adverse impact on the latter, taking fully into account the legitimate } \\
\text { priority needs of developing countries for the achievement of sustained economic } \\
\text { growth and the eradication of poverty" (forward); "The objectives of the Centre shall } \\
\text { be: (a) protection of the climate system of Members of the Centre for the benefit of } \\
\text { present and future generations of their peoples" (Article 4a); "In order to achieve its } \\
\text { objectives set out in Article 4, the Centre shall perform the following functions: (f) } \\
\text { co-ordinating (and initiating) the development of regional research programmes, } \\
\text { including adaptation of global climate and impact modelling efforts and specialised } \\
\text { training focussed on effective adaptation to global climate change" (Article 5f); The } \\
\text { Agreement has } 41 \text { references to climate change; } 7 \text { references to adaptation } \\
\text { (CARICOM Secretariat, 2011a, online). } \\
\text { The CCCCC's Mission Statement is: "Through its role as a Centre of Excellence, the } \\
\text { Centre will support the people of the Caribbean as they address the impact of climate } \\
\text { variability and change on all aspects of economic development through the provision } \\
\text { of timely forecasts and analyses of potentially hazardous impacts of both natural and } \\
\text { man-induced climatic changes on the environment, and the development of special } \\
\text { programmes which create opportunities for sustainable development" (CCCCC, } \\
\text { 2015f, online). }\end{array}$ & $\square$ \\
\hline & $\begin{array}{l}\text { 3. Climate change adaptation is a } \\
\text { current goal of the organisation. }\end{array}$ & $\begin{array}{l}\text { The } 5 \text { strategic elements of the CCCCC/CARICOM Regional Framework (valid } \\
\text { 2011-2021) include: "(a) Mainstreaming climate change adaptation strategies into the } \\
\text { sustainable development agendas of CARICOM states"; "(b) Promoting the } \\
\text { implementation of specific adaptation measures to address key vulnerabilities in the } \\
\text { region"; "(d) Encouraging action to reduce the vulnerability of natural and human }\end{array}$ & $\nabla$ \\
\hline
\end{tabular}




\begin{tabular}{|c|c|c|c|}
\hline \multirow[t]{3}{*}{ SUB-COMPONENT } & INDICATOR & $\begin{array}{l}\text { EVIDENCE } \\
\end{array}$ & RATING \\
\hline & & $\begin{array}{l}\text { systems in CARICOM countries to the impacts of a changing climate" (CCCCC, } \\
2012 \text {, p. 18). }\end{array}$ & \\
\hline & $\begin{array}{l}\text { 4. The current strategic plan } \\
\text { contains specific climate change } \\
\text { adaptation objectives. }\end{array}$ & $\begin{array}{l}\text { The objective of the Regional Implementation Plan, part of the CCCCC/CARICOM } \\
\text { Regional Framework, is "to build resilience to a changing climate and create low } \\
\text { carbon economies" by "delivering actions in the following areas: (1) institutional and } \\
\text { governance building blocks, (2) cross-cutting challenges, and (3) technical and } \\
\text { physical impacts" (CCCCC, 2012, p. 50). The Plan has } 8 \text { key milestones, including } \\
\text { (1) research component completed, (3) Regional Coordinating Mechanism } \\
\text { established, (8) policy review completed. All milestones have target completion } \\
\text { months and years (CCCCC, 2012, p. 116). } \\
\text { Goals associated with relevant Strategic Elements: } \\
\text { 2.1: Promote the adoption of measures and disseminate information that would make } \\
\text { water supply systems resilient to climate-induced damage } \\
\text { 2.2: Promote the implementation of measures to reduce climate impacts on coastal } \\
\text { and marine infrastructure } \\
\text { 2.3: Promote the adoption of measures and dissemination of information that would } \\
\text { adapt tourism activities to climate impacts } \\
\text { 2.4: Promote sound conservation practices in coastal and marine ecosystems to } \\
\text { shelter these resources from climate-induced damage } \\
\text { 2.5: Promote the adoption of sound practices and measures to prevent and/or reduce } \\
\text { climate-induced health impacts in the community. }\end{array}$ & $\diamond$ \\
\hline & $\begin{array}{l}\text { There is no other regional } \\
\text { organisation with similar climate } \\
\text { change adaptation goals. }\end{array}$ & $\begin{array}{l}\text { The CARICOM website lists } 34 \text { regional organisations and institutions in the } \\
\text { Caribbean. One of these institutions has climate change in its name-the 'Caribbean } \\
\text { Planning for Adaptation to Global Climate Change' (CPACC) (CARICOM } \\
\text { Secretariat, 2011d). However, elsewhere on the website, CPACC is identified as a } \\
\text { project (CARICOM Secretariat, 2011c). } \\
\text { See also (CCCCC, 2012, p. 100). } \\
\text { Two organisations have 'environment' in their name-Caribbean Environment } \\
\text { Health Institute (CEHI) (now CARPHA) and Caribbean Environmental Reporters } \\
\text { Network (CERN). } \\
\text { CEHI/CARPHA is a Technical Institute of CARICOM. Its mission statement does } \\
\text { not mention climate change-"CEHI provides technical and advisory services to } \\
\text { Member States in all areas of environmental management including: }\end{array}$ & $\nabla$ \\
\hline
\end{tabular}




\begin{tabular}{|c|c|c|c|}
\hline SUB-COMPONENT & INDICATOR & EVIDENCE & RATING \\
\hline & & 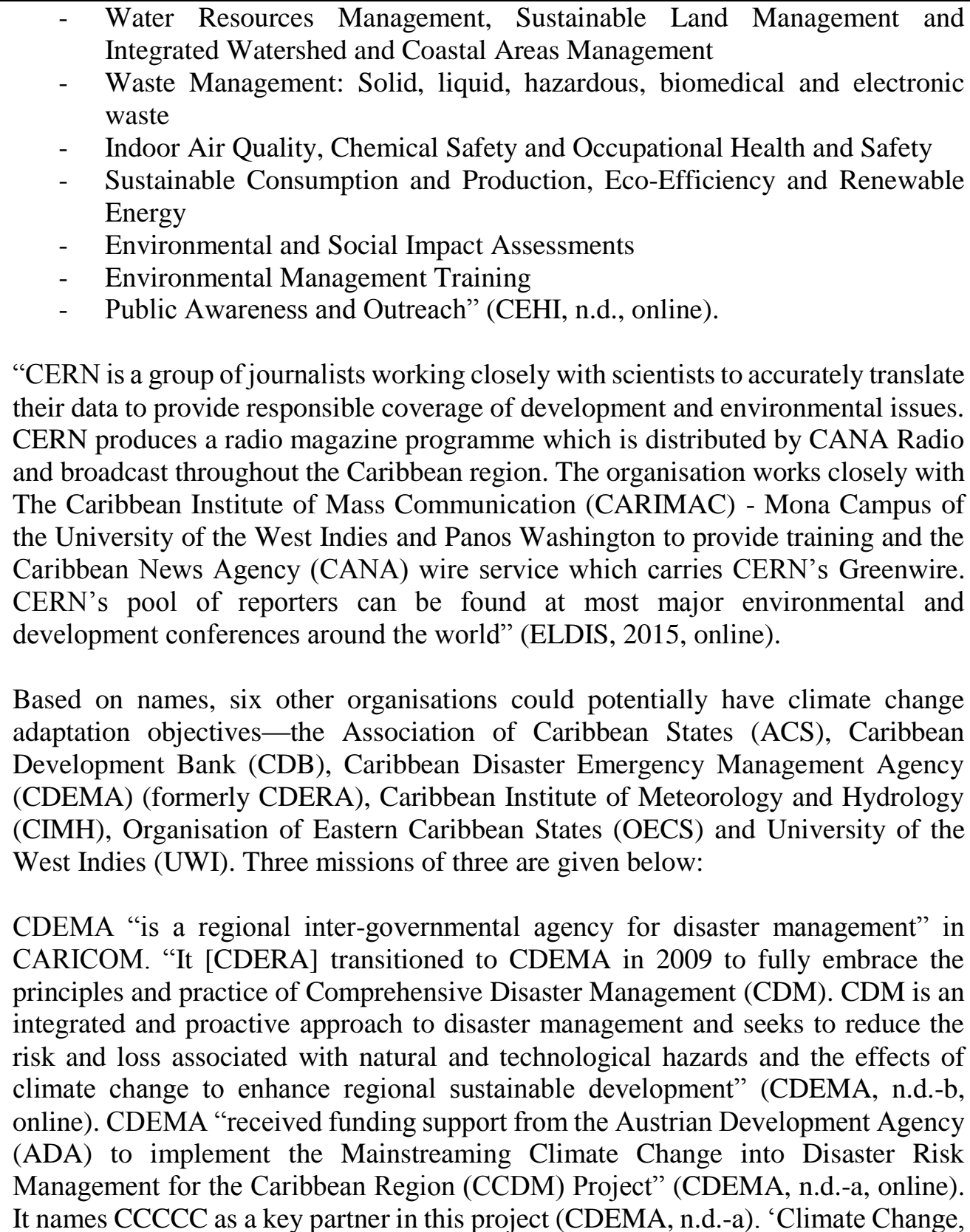 & \\
\hline
\end{tabular}




\begin{tabular}{|c|c|c|c|}
\hline SUB-COMPONENT & INDICATOR & EVIDENCE & RATING \\
\hline & & $\begin{array}{l}\text { Disaster Risk Reduction and Environment Sub-Committee' is a sub-committee of } \\
\text { CDEMA's Technical Advisory Committee (TAC) (CDEMA, n.d.-b). } \\
\text { "The Caribbean Institute for Meteorology and Hydrology (CIMH) is a training and } \\
\text { research organisation formed by the amalgamation of the Caribbean Meteorological } \\
\text { Institute (CMI) and Caribbean Operational Hydrological Institute (COHI)" "The role } \\
\text { and mission of the CIMH is to improve the meteorological and hydrological services } \\
\text { and to assist in promoting the awareness of the benefits of these services for the } \\
\text { economic well-being of the CMO countries. This is achieved through training, } \\
\text { research and investigations, and the provision of specialised services and advice" } \\
\text { (CIMH, 2015, online). } \\
\text { UWI at Mona (Jamaica) has a Climate Studies Group (CSGM). It "was formed within } \\
\text { the Physics Department at the University of the West Indies in 1994 under the } \\
\text { initiative of the Honourable Professor A. Anthony Chen, O.M. The CSGM comprises } \\
\text { faculty members, consultants, technical staff and postgraduate students - all working } \\
\text { together to increasingly understand the workings of local, regional and global } \\
\text { climate". } \\
\text { "The mission of the CSGM is as follows: } \\
\text { - To investigate and understand the mechanisms responsible for } \\
\quad \text { o the mean climate and } \\
\quad \text { o extremes in climate in both Jamaica and the wider Caribbean } \\
\text { - To use this understanding to predict climate on a seasonal and annual basis } \\
\text { - To promote awareness of global warming } \\
\text { - To determine how anthropogenic climate change will manifest itself in the } \\
\text { Caribbean region } \\
\text { - To investigate the potential for exploiting renewable energy resources } \\
\text { To investigate and promote the advantageous uses of climate prediction in } \\
\text { socio-economic sectors" (UWI, 2015, online). } \\
\text { CSGM is also engaged in CCA projects e.g. PPCR (see Williams-Raynor, 2015). } \\
\text { UWI at St Augustine (Trinidad and Tobago) has "an Office of Research Development } \\
\text { and Knowledge Transfer (ORDKT) that supports all research and knowledge transfer } \\
\text { activities. ORDKT links UWI experts to national and international corporations. }\end{array}$ & \\
\hline
\end{tabular}




\begin{tabular}{|c|c|c|c|}
\hline SUB-COMPONENT & INDICATOR & EVIDENCE & RATING \\
\hline & & $\begin{array}{l}\text { multinational organizations, governments, NGOs and funding agencies. Part of its } \\
\text { service includes: research management and research capacity development activities; } \\
\text { planning and implementation of strategies; policy making; seek funding for project } \\
\text { management and execution; development and management of key stakeholder } \\
\text { relationships for research collaboration. Recent research funded projects: } \\
\text { incorporation of RE and energy efficiency into the academic programmes; Caribbean } \\
\text { climate change adaptation and mitigation scenarios; geoinformatics technology for } \\
\text { climate change monitoring, mitigation and adaptation strategies; climate change } \\
\text { adaptation strategies for water resources and human livelihoods" (emphasis added) } \\
\text { (UNEP-REGATTA, 2015, online). } \\
\text { *Key role of CCCCC is coordinating and centralising efforts; other organisations } \\
\text { doing aspects of the CCCCC's work* }\end{array}$ & \\
\hline \multirow[t]{4}{*}{$\begin{array}{l}\text { 2. Governance and } \\
\text { leadership }\end{array}$} & $\begin{array}{l}\text { 8. The Board provides visionary } \\
\text { leadership and strategic direction. }\end{array}$ & & \\
\hline & $\begin{array}{l}\text { 9. The organisation evaluates } \\
\text { organisational performance at } \\
\text { least annually. }\end{array}$ & $\begin{array}{l}\text { The Centre "is strengthening its capacity by establishing a Monitoring and Evaluation } \\
\text { Unit to better prepare it to function as an implementing agency with the requisite } \\
\text { technical capacity to institute projects on par with international organizations } \\
\text { operating in the region. The new Unit will also advance the Centre's capacity to } \\
\text { advise and help governments develop, monitor and evaluate programmes in } \\
\text { accordance with its mandate as the region's key node of information and action on } \\
\text { climate change" (CCCCC, 2015a, online). } \\
\text { *This Unit has not yet been established but could do internal M\&E* }\end{array}$ & $\diamond$ \\
\hline & $\begin{array}{l}\text { 10. Executive management (can also } \\
\text { include members of the } \\
\text { Board/Governing is Body) } \\
\text { decision-making is done by } \\
\text { consensus or majority vote. }\end{array}$ & $\begin{array}{l}\text { Article 10(5) of the Establishment Agreement states that: "The Board shall take } \\
\text { decisions by a qualified majority of three-quarters of the votes of its membership" } \\
\text { (CARICOM Secretariat, 2011a, online). Article 10(1) of the Agreement states that: } \\
\text { "The Board of Governors (hereinafter called "the Board" shall consist of } \\
\text { representatives of Members and institutions, both public and private, set out in the } \\
\text { Annex to this Agreement" (CARICOM Secretariat, 2011a, online). }\end{array}$ & $\nabla$ \\
\hline & $\begin{array}{l}\text { 11. Executive management staff (can } \\
\text { also include members of the } \\
\text { Board/Governing Body) are } \\
\text { qualified and/or equipped to } \\
\text { achieve the goals of the } \\
\text { organisation. }\end{array}$ & $\begin{array}{l}\text { CCCCC is "overseen by a Board of Directors [also called 'Board of Governors'] } \\
\text { selected by the Council of Ministers designated for this purpose by the CARICOM } \\
\text { Heads of Government" (CCCCC, 2015i, online). } \\
\text { Dr Leonard A. Nurse chairs the current } 11 \text { member Board, representing the } \\
\text { Government of Barbados (CCCCC, 2015i). Dr Nurse is an IPCC WGII scientist and } \\
2007 \text { Nobel Prize Laureate. He is "a member of the CARICOM Task Force on } \\
\text { climate change, established by regional Heads of Government in 2009" (UPRM, n.d., }\end{array}$ & $\square$ \\
\hline
\end{tabular}




\begin{tabular}{|c|c|c|c|}
\hline SUB-COMPONENT & INDICATOR & EVIDENCE & RATING \\
\hline & & 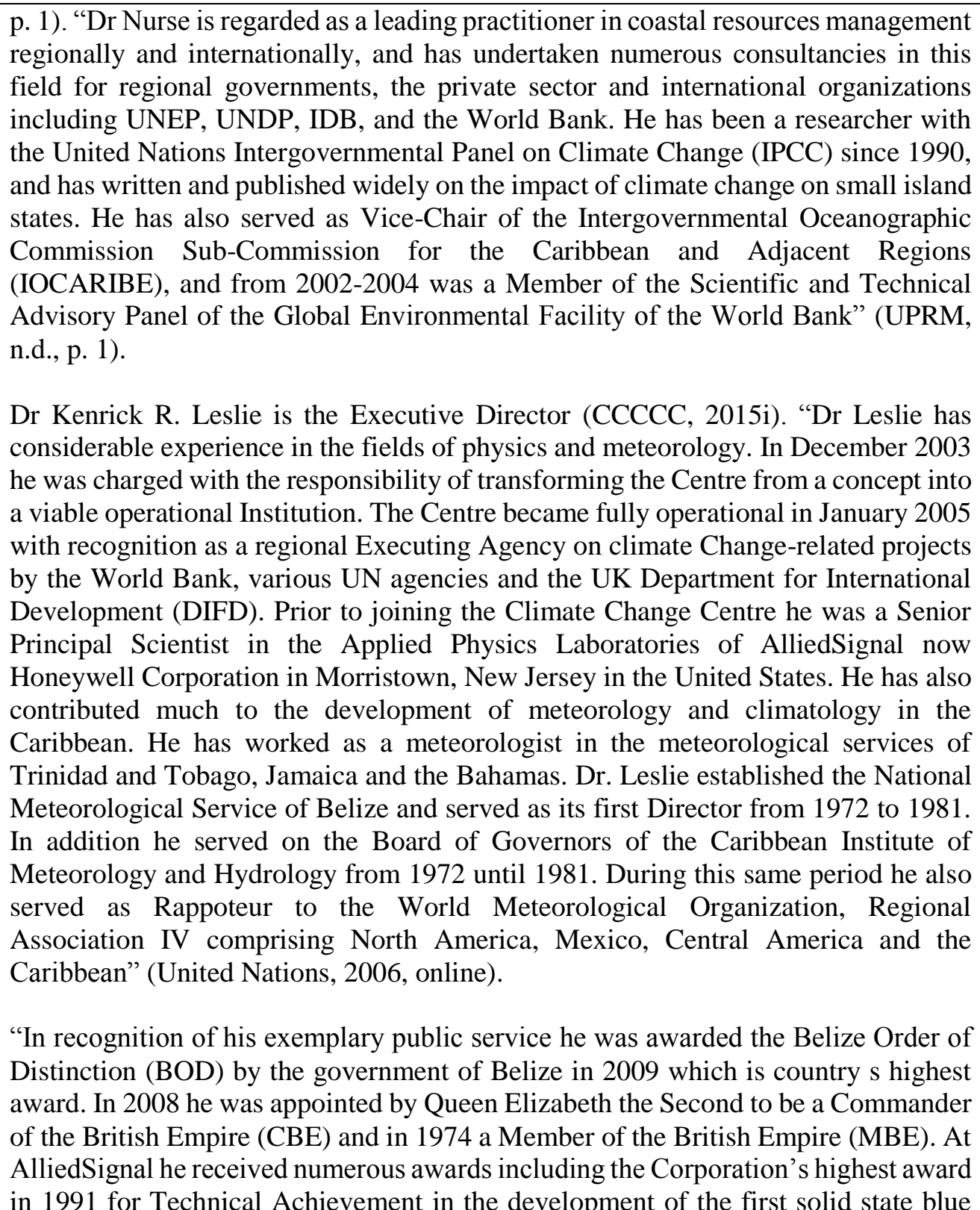 & \\
\hline
\end{tabular}




\begin{tabular}{|c|c|c|c|}
\hline \multirow[t]{2}{*}{ SUB-COMPONENT } & INDICATOR & EVIDENCE & \multirow[t]{2}{*}{ RATING } \\
\hline & & $\begin{array}{l}\text { laser for underwater to space communications" (Cross Strait Interflow Prospect } \\
\text { Foundation, 2010, p. 27). }\end{array}$ & \\
\hline & $\begin{array}{l}\text { 12. Executive management staff } \\
\text { disclose potential conflicts of } \\
\text { interest. }\end{array}$ & & \\
\hline & $\begin{array}{l}\text { 13. The organisation attracts, retains } \\
\text { and develops talent. }\end{array}$ & $\begin{array}{l}\text { Dr Ulric Trotz is the current Deputy Director and Science Advisor (CCCCC, 2015i). } \\
\text { "Dr Trotz is a science advisor with the Caribbean Community Climate Change Centre } \\
\text { in Belize. He has a PhD in organic chemistry and comes to us with a wide and varied } \\
\text { experience and expertise in the fields of science, government service, and academe. } \\
\text { He's published and lectured widely on climate change issues, and in his capacity as } \\
\text { review editor for the chapter on Small Island Developing States in the Fourth } \\
\text { Assessment Report of the IPCC, he was a member of a group of scientists that was } \\
\text { awarded the Nobel Prize in 2008. He's been recognized for his public service in his } \\
\text { native country of Guyana, and was recently inducted as an honorary distinguished } \\
\text { fellow at the University of the West Indies in Barbados" (Columbia University, 2010, } \\
\text { p. 10). In November } 2005 \text { (the Centre officially opened in August 2005), Dr Trotz } \\
\text { was already with the 5Cs (see Government of Belize, 2005, p. xxiv). In February } \\
\text { 2006, he was the Programme Manager of the MACC Project (CARICOM and UNDP, } \\
\text { 2006). } \\
\text { Mr Carlos Fuller is the current International and Regional Liaison Officer (CCCCC, } \\
\text { 2015i) and joined the CCCCC at some point between 2006 and 2008. In November } \\
\text { 2005, Mr Fuller was the National Focal Point for Belize for the UNFCCC. He was } \\
\text { also the Chief Meteorologist at the National Meteorological Service in the Ministry } \\
\text { of Natural Resources, Local Government and the Environment (MNRLGE), Belize } \\
\text { (see Government of Belize, 2005, p. xxiv). In February 2006, Mr Fuller was still with } \\
\text { the MNRLGE (CARICOM and UNDP, 2006). In June 2008, he participated in the } \\
\text { Fourth Meeting of the GCOS Cooperation Board as the Deputy Director of the } \\
\text { CCCCC (WMO, 2008). } \\
\text { In 2014, Ms Sharon Olive Lindo was a Policy Officer (UNFCCC Secretariat, 2014). } \\
\text { In November 2005, Ms Lindo was the Sustainable Development Officer in the } \\
\text { MNRLGE, Belize (see Government of Belize, 2005, p. xxiv). }\end{array}$ & $\diamond$ \\
\hline & $\begin{array}{l}\text { 14. Leaders create a dynamic } \\
\text { organisational culture, making } \\
\text { the organisation a desirable place } \\
\text { to work. }\end{array}$ & & \\
\hline
\end{tabular}




\begin{tabular}{|c|c|c|c|}
\hline SUB-COMPONENT & INDICATOR & EVIDENCE & RATING \\
\hline \multirow[t]{2}{*}{ 3. Resources } & $\begin{array}{l}\text { 12. There are staff members } \\
\text { exclusively dedicated to climate } \\
\text { change adaptation. }\end{array}$ & $?$ & $(\mathrm{NE})$ \\
\hline & $\begin{array}{l}\text { Staff are qualified and have } \\
\text { experience in climate change } \\
\text { adaptation. }\end{array}$ & 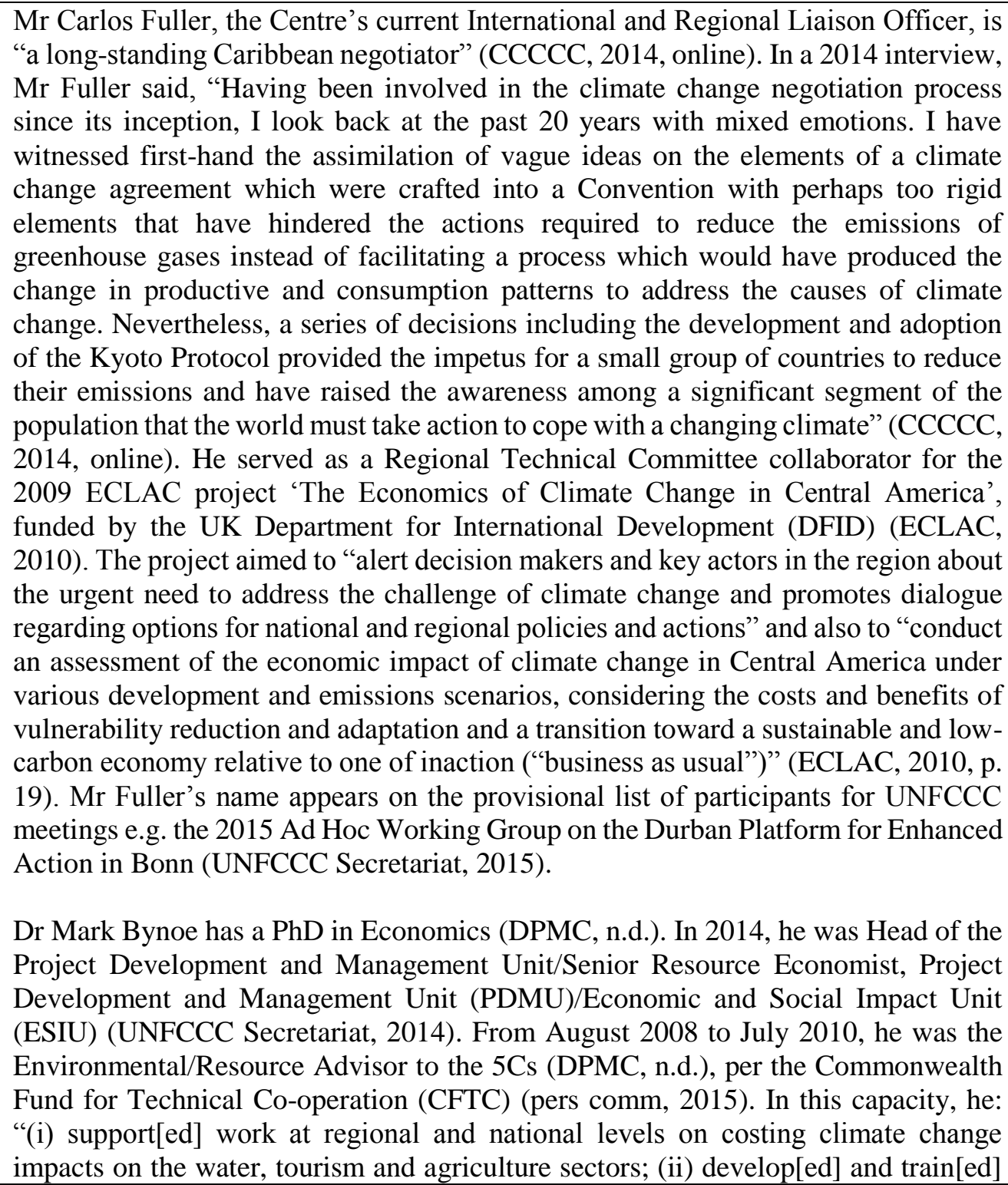 & $\nabla$ \\
\hline
\end{tabular}




\begin{tabular}{|c|c|c|c|}
\hline SUB-COMPONENT & INDICATOR & $\begin{array}{l}\text { EVIDENCE } \\
\end{array}$ & RATING \\
\hline & & $\begin{array}{l}\text { regional personnel on costing adaptation options in these sectors and using these } \\
\text { results to inform sectoral adaptation policy and implementation plans; (iii) advice[d] } \\
\text { [sic] the organizations on the use of information derived from assessments for } \\
\text { decision making in climate change adaptation; (iv) mentor[ed] and teach [taught] } \\
\text { staff on approaches to cost benefit analyses of adaptation options including the costs } \\
\text { of delayed action; (v) prepare[d] training material on the methods utilized in carrying } \\
\text { out costing of impacts and adaptation options to include methods for assessment of } \\
\text { environmental services; (vi) liaise[d] closely with national climate change focal } \\
\text { points training institutions within the region and other regional institutions } \\
\text { conducting similar activities" (DPMC, n.d., p. 2). Between May } 2008 \text { and February } \\
\text { 2009, he was Project Coordinator, Economist and Policy Analyst for the development } \\
\text { of a National Agricultural Sector Strategy and Action Plan for Guyana to Adapt to } \\
\text { Climate Change (DPMC, n.d.). In April 2000, he "prepared, in collaboration with one } \\
\text { other professional, a Coastal Vulnerability Study for Guyana due to Climate Change } \\
\text { for the Guyana Environmental Protection Agency and the Organisation of American } \\
\text { States" (DPMC, n.d., p. 6). }\end{array}$ & \\
\hline & $\begin{array}{l}\text { 13. Staff are qualified and have } \\
\text { experience in project/program } \\
\text { management. }\end{array}$ & $\begin{array}{l}\text { In 2014, Dr Mark Bynoe was Head of the Project Development and Management } \\
\text { Unit/Senior Resource Economist, Project Development and Management Unit } \\
\text { (PDMU)/Economic and Social Impact Unit (ESIU) (UNFCCC Secretariat, 2014). In } \\
2007 \text {, while Managing Director of Development Policy and Management } \\
\text { Consultants, he gained a Certificate in Program Monitoring and Evaluation from St. } \\
\text { Georges University in Grenada (DPMC, n.d.). He has "a wealth of experience in } \\
\text { project and program planning" (DPMC, n.d., p. 1). Between } 1994 \text { and 2009, he } \\
\text { managed, coordinated and/or implemented 45+ projects and programs e.g. coastal } \\
\text { vulnerability studies, livelihoods assessments and feasibility studies (DPMC, n.d.). } \\
\text { In 2014, Mr Keith Egbert Nichols was Project Development Specialist in the Project } \\
\text { Development and Management Unit (PDMU) (UNFCC Secretariat, 2014). In 1998, } \\
\text { Mr Nichols worked for the OECS on matters relating to the Cartagena Protocol, } \\
\text { SPAW etc. (UNEP CEP, 1998). In 2012, he was Programme Officer in the OECS } \\
\text { Environment and Sustainable Development Unit (OECS, 2012). This Unit was } \\
\text { responsible for the implementation of the OPAAL Project aimed "to contribute to the } \\
\text { conservation of biodiversity of global importance in the participating countries of the } \\
\text { OECS by removing barriers and minimizing the challenges facing the effective } \\
\text { management of protected areas (PAs). Participating countries have already identified } \\
\text { priority sites for project interventions. A major component will focus on providing } \\
\text { opportunities for enhancing livelihoods for communities that are dependent on the } \\
\text { resources in these protected areas, through arrangements that will permit users to earn }\end{array}$ & $\nabla$ \\
\hline
\end{tabular}




\begin{tabular}{|c|c|c|c|}
\hline SUB-COMPONENT & INDICATOR & $\begin{array}{ll}\text { EVIDENCE } \\
\end{array}$ & RATING \\
\hline & & $\begin{array}{l}\text { a living without destroying the future value of the resources. Target groups in these } \\
\text { areas will be provided financial and other management assistance to take advantage } \\
\text { or the new livelihood opportunities through a special developmental fund" (OECS, } \\
2012 \text {, online). }\end{array}$ & \\
\hline & $\begin{array}{l}\text { 14. Staff participate in ongoing } \\
\text { training programs. }\end{array}$ & $\begin{array}{l}\text { In 2009, Mr Carlos Fuller, the Centre's current International and Regional Liaison } \\
\text { Officer, participated in a UNFCCC Technical Workshop on Increasing Economic } \\
\text { Resilience to Climate Change and Reducing Reliance on Vulnerable Economic } \\
\text { Sectors through Economic Diversification (IISD Reporting Services, 2009). In 2010, } \\
\text { he participated in a UNFCCC Latin America and Caribbean Regional Workshop on } \\
\text { Preparing Technology Transfer Projects for Financing (UNFCCC Secretariat, 2010). } \\
\text { *Little evidence of other staff participating in training; most training sponsored by } \\
\text { external organisations such as the UNFCCC Secretariat* }\end{array}$ & $\diamond$ \\
\hline & $\begin{array}{l}\text { 15. Staff performance is appraised } \\
\text { (formally or informally) at least } \\
\text { annually. }\end{array}$ & $?$ & (NE) \\
\hline & $\begin{array}{l}\text { 16. The organisation has untied } \\
\text { funding. }\end{array}$ & $\begin{array}{l}\text { Article 16(2) of the Establishment Agreement provides for the establishment of a } \\
\text { reserve fund: "The resources of the Reserve Fund shall consist of the following: } \\
\text { - grants from international donors and sponsors of the Centre; } \\
\text { - grants from Members and Associate Members; } \\
\text { - unspent balances from the annual budgets of the Centre; } \\
\text { - revenues derived from the operations of the Centre; } \\
\text { income from investments of the Centre" (CARICOM Secretariat, 2011a, } \\
\text { online). } \\
\text { The Centre is "advancing efforts to set up a Trust Fund. The Fund, which has been } \\
\text { seeded with US } \$ 1 M \text { from the Republic of Trinidad and Tobago, will be an } \\
\text { independent arrangement administrated by the CDB [Caribbean Development Bank] } \\
\text { that would allow the Centre to co-finance projects and fund project priorities over the } \\
\text { long-term" (CCCCC, 2015a, online). }\end{array}$ & $\square$ \\
\hline & $\begin{array}{l}\text { 17. The organisation has funds } \\
\text { exclusively dedicated to climate } \\
\text { change adaptation. }\end{array}$ & $\begin{array}{l}\text { "The Centre continued the execution of eight medium to large projects/programmes } \\
\text { over the last twelve months [2014-2015]. The Centre's most recent programme is a } \\
€ 12.8 \text { million initiative to address ecosystems-based adaptation under an agreement } \\
\text { with the German Development Bank (KfW). The KfW supported engagement seeks } \\
\text { to protect the region's extensive coastal resources through a combination of } \\
\text { ecosystems-based adaptation and environmental engineering approaches that will }\end{array}$ & $\nabla$ \\
\hline
\end{tabular}




\begin{tabular}{|c|c|c|c|}
\hline SUB-COMPONENT & INDICATOR & $\begin{array}{l}\text { EVIDENCE } \\
\text { also embed livelihood considerations as a core element of the programme. The } \\
\text { comprehensive investment under the initiative developed by the Centre, in } \\
\text { conjunction with the KfW, will focus on enhancing the resilience of the region's } \\
\text { coastal resources to the impacts of climate change and climate variability" (CCCCC, } \\
\text { 2015a, online). }\end{array}$ & RATING \\
\hline & $\begin{array}{l}\text { 18. External funding to the } \\
\text { organisation has increased over } \\
\text { the past } 5 \text { years. }\end{array}$ & $\begin{array}{l}\text { "The Centre has expanded rapidly since it commenced operations in } 2005 \text {, having } \\
\text { developed the capacity to successfully execute a suite of regional climate change } \\
\text { related programmes worth between US } \$ 40 \text { and US } \$ 50 \text { million over the last five } \\
\text { years" (CCCCC, 2015a, online). } \\
\text { "Australia Aid has committed AU } \$ 4.19 \text { mill for direct financial support to the } \\
\text { CCCCC. The EC have provided } € 8 \mathrm{~m} \text { for the execution of a CARIFORUM } \\
\text { programme on climate change which will significantly increase climate and coral reef } \\
\text { monitoring and early warning systems as well as fund adaptation pilots. The } \\
\text { Caribbean Development Bank (CDB) is also contributing USD } 470,250 \text { from its } \\
\text { Special Develo pment Fund to fund technical services for the development of a } \\
\text { pipeline of C C investment projects. CDKN are supporting the development of a risk } \\
\text { management framework for decision making in } 2-3 \text { states ( } £ 405,000) \text {, In total } \\
£ 16.27 \text { m has been committed to the IP through CCCCC to date (DFID 's contribution } \\
\text { being } 30 \% \text { of this Sum)" (CDB, } 2012, \text { p. } 8 \text { ). }\end{array}$ & $\diamond$ \\
\hline & $\begin{array}{l}\text { 19. The organisation has multiple } \\
\text { funding sources. }\end{array}$ & $\begin{array}{l}\text { The Centre "is primarily funded through grants and not government subventions" } \\
\text { (CCCCC, 2015a, online). Based on projects identified as "current" (CCCCC, 2015b, } \\
\text { online): } \\
\text { - "In December 2010, in Cancun, Mexico, SIDS DOCK was launched with } \\
\text { four Partners: the United Nations Development Programme (UNDP), the } \\
\text { World Bank, AOSIS and the Government of Denmark, which announced a } \\
\text { grant of USD14.5 million in start-up contributions" (emphasis added) } \\
\text { (CCCCC, 2015k, online). } \\
\text { "The Database Management System for Regional Integrated Observing } \\
\text { Network for Environmental Change in the Wider Caribbean (DBS) is } \\
\text { executed by the Caribbean Community Climate Change Centre (CCCC) } \\
\text { with the financial support of the Inter-American Development Bank (IDB)" } \\
\text { (emphasis added) (CCCCC, 2015g, online). } \\
\text { - The Coastal Protection for Climate Change Adaptation in the Small Island } \\
\text { States in the Caribbean Project is funded by the German Ministry for } \\
\text { Economic Cooperation and Development (BMZ) (CCCCC, 2015b). }\end{array}$ & $\square$ \\
\hline
\end{tabular}




\begin{tabular}{|c|c|c|c|}
\hline SUB-COMPONENT & INDICATOR & EVIDENCE & RATING \\
\hline & & $\begin{array}{l}\text { "Executive Director Dr Kenrick Leslie says the Centre, under a directive from } \\
\text { CARICOM Heads, has been "working with national governments to put together } \\
\text { programmes that would help them develop bankable projects that can be funded } \\
\text { under the various mechanisms under the United Nations Framework Convention on } \\
\text { Climate Change. The Centre is putting maximum effort to ensure CARICOM } \\
\text { Member States get their fair share of the Green Climate Fund (GCF), Adaptation } \\
\text { Fund (AF) and other funds to help them in their adaptation efforts. That is our primary } \\
\text { thrust - to meet the mandate given to us by the regional Heads" (CCCCC, 2015a, } \\
\text { online). } \\
\text { CCCCC is the RIE for Green Climate Fund (Jamaica Observer, 2015). }\end{array}$ & \\
\hline & $\begin{array}{l}\text { 20. The organisation has financial } \\
\text { reserves. }\end{array}$ & $\begin{array}{l}\text { The Centre is "advancing efforts to set up a Trust Fund. The Fund, which has been } \\
\text { seeded with US } \$ 1 M \text { from the Republic of Trinidad and Tobago, will be an } \\
\text { independent arrangement administrated by the CDB [Caribbean Development Bank] } \\
\text { that would allow the Centre to co-finance projects and fund project priorities over the } \\
\text { long-term" (CCCCC, } 2015 \text { a, online). }\end{array}$ & $\nabla$ \\
\hline & $\begin{array}{l}\text { 21. The organisation has sufficient } \\
\text { technological resources (e.g. } \\
\text { intellectual property rights, } \\
\text { patents, copyright, software } \\
\text { licences etc.) to carry out its } \\
\text { climate change adaptation } \\
\text { mandate. }\end{array}$ & & \\
\hline \multirow[t]{3}{*}{$\begin{array}{l}\text { 4. Structure, systems } \\
\text { and processes }\end{array}$} & $\begin{array}{l}\text { 9. There is a low degree of hierarchy } \\
\text { (i.e. few hierarchical levels). }\end{array}$ & & \\
\hline & $\begin{array}{l}\text { 10. The organisation has a human } \\
\text { resource management system that } \\
\text { supports the shaping of } \\
\text { organisational culture and staff } \\
\text { recruitment, training, } \\
\text { development and retention. }\end{array}$ & & \\
\hline & $\begin{array}{l}\text { 11. There is a financial management } \\
\text { system that meets International } \\
\text { Financial Reporting Standards } \\
\text { (IFRS) or its equivalent. }\end{array}$ & $\begin{array}{l}\text { Article } 11(\mathrm{~m}) \text { of the Establishment Agreement states that that Board shall: "prepare } \\
\text { for submission to the Council, annual financial reports regarding the investments and } \\
\text { use of the resources of the Reserve Fund" (CARICOM Secretariat, 2011a, online). } \\
\text { Article } 15(7) \text { of the Establishment Agreement states that: "The finances of the } \\
\text { Reserve Fund shall be audited annually by the auditors appointed by the Centre to }\end{array}$ & $\diamond$ \\
\hline
\end{tabular}




\begin{tabular}{|c|c|c|c|}
\hline SUB-COMPONENT & INDICATOR & $\begin{array}{ll}\text { EVIDENCE } \\
\end{array}$ & RATING \\
\hline & & $\begin{array}{l}\text { audit its accounts. The Report of the Auditors shall be submitted to the Board for } \\
\text { consideration and approval" (CARICOM Secretariat, 2011a, online). } \\
\text { "Following decisions taken at last year's Board of Governors meeting, the Board has } \\
\text { strengthened its fiduciary oversight through a Finance and Audit Sub-Committee of } \\
\text { the Board of Governors, annual internal audits" (CCCCC, 2015a, online). }\end{array}$ & \\
\hline & $\begin{array}{l}\text { 12. The organisation applies risk } \\
\text { management principles in its } \\
\text { decision-making processes. }\end{array}$ & & \\
\hline & $\begin{array}{l}\text { 13. The organisation has a } \\
\text { centralised, user-friendly internal } \\
\text { data management system. }\end{array}$ & & \\
\hline & $\begin{array}{l}\text { 14. The organisation has a user- } \\
\text { friendly project/program } \\
\text { management system (e.g. that } \\
\text { supports staff to identify, } \\
\text { schedule and track resources } \\
\text { etc.). }\end{array}$ & & \\
\hline & $\begin{array}{l}\text { 15. There are mechanisms that } \\
\text { support vertical and horizontal } \\
\text { communication. }\end{array}$ & & \\
\hline & $\begin{array}{l}\text { 16. There are internal dispute } \\
\text { resolution protocols. }\end{array}$ & & \\
\hline \multirow[t]{2}{*}{$\begin{array}{ll}\text { 6. } & \text { Research } \\
& \text { collaboration } \\
\text { capacity }\end{array}$} & $\begin{array}{l}\text { 5. The organisation has plans and } \\
\text { policies that support research. }\end{array}$ & $\begin{array}{l}\text { Article } 5 \text { of the Establishment Agreement states that functions of the Centre include: } \\
\text { "(f) co-ordinating (and initiating) the development of regional research programmes, } \\
\text { including adaptation of global climate and impact modelling efforts and specialised } \\
\text { training focussed on effective adaptation to global climate change" (CARICOM } \\
\text { Secretariat, 2011a, online). } \\
\text { Article } 15 \text { of the Establishment Agreement states that functions of the Technical } \\
\text { Secretariat include: "(e) provide advice on scientific programmes, international co- } \\
\text { operation in research and development relating to climate change, as well as on } \\
\text { developing relevant endogenous capabilities" (emphasis added) (CARICOM } \\
\text { Secretariat, 2011a, online). }\end{array}$ & $\nabla$ \\
\hline & $\begin{array}{l}\text { 6. There are organisational funds } \\
\text { allocated for research. }\end{array}$ & $?$ & $(\mathrm{NE})$ \\
\hline
\end{tabular}




\begin{tabular}{|c|c|c|c|}
\hline SUB-COMPONENT & INDICATOR & $\begin{array}{l}\text { EVIDENCE } \\
\end{array}$ & RATING \\
\hline & $\begin{array}{l}\text { 7. The organisation has equipment, } \\
\text { expertise and/or resources (e.g. } \\
\text { access to journal articles etc.) for } \\
\text { research. }\end{array}$ & $\begin{array}{l}\text { The CCCCC is part of a research consortium in the Caribbean (Colley et al., 2011). } \\
\text { The consortium carries out "several activities that make up the Caribbean Modelling } \\
\text { Initiatives (CMIS), which will provide outputs that can assist decision makers in the } \\
\text { public and private sector understand the predicted changes in climate, their impacts } \\
\text { and socio-economic effects in the Caribbean region. The modelling initiatives are } \\
\text { divided into three sections: } 1 \text {. Caribbean Climate Modelling Initiative (CCMI), } 2 . \\
\text { Impact Studies Modelling, and 3. Economic Modelling" (Colley et al., 2011, p. 15). } \\
\text { The Centre submitted "information regarding its efforts in climate modelling, } \\
\text { downscaling and the use of climate change scenarios [...]in response to SBSTA's } \\
\text { call contained in FCCC/SBSTA/2006/11 paragraph } 42 \text { inviting regional } \\
\text { organizations to submit information on ways in which they contribute to: (a) } \\
\text { Development, availability and use of climate models, and development of, access to, } \\
\text { and use of climate change scenarios, especially those that provide subregional and } \\
\text { regional specificity, including data downscaled from general circulation models; (b) } \\
\text { Enhanced capacity and experience with the use of these different models, statistical } \\
\text { approaches and outputs, and any available training opportunities; and (c) } \\
\text { Identification and reduction of uncertainties" (CCCCC, 2008, p. 1). } \\
\text { "Japan's Asia-Pacific Network for Global Change Research and the Caribbean } \\
\text { region's CCCCC operate in a similar way" (UNFCCC Secretariat, 2009, p. 9). }\end{array}$ & $\square$ \\
\hline & $\begin{array}{l}\text { 8. The organisation's current } \\
\text { strategic plan (or a similar } \\
\text { document) outlines plans for } \\
\text { collaboration with multiple } \\
\text { stakeholders on adaptation- } \\
\text { related initiatives. }\end{array}$ & $\begin{array}{l}\text { Article } 5 \text { of the Establishment Agreement states that functions of the Centre include: } \\
\text { "(a) collecting, analysing, storing, retrieving and disseminating meteorological and } \\
\text { sea-level data relevant to the observation of climate change and facilitating, in } \\
\text { collaboration with specialised Caribbean agencies, the collection of information } \\
\text { about the impact of climate change on the economic sectors in the Caribbean; [...] } \\
\text { (d) in collaboration with Members and relevant agencies, developing special } \\
\text { programmes to address implications in the Region for coastal zone management, } \\
\text { disaster management, and potentially vulnerable sectors such as tourism, health, } \\
\text { agriculture and insurance" (emphasis added) (CARICOM Secretariat, 2011a, online). } \\
\text { The Board of Directors/Governors, at its June } 2015 \text { meeting, "agreed that the Centre } \\
\text { will deepen engagement with the private sector to ensure broad utilisation of the } \\
\text { seminal Caribbean Climate Online Risk and Adaptation Tool (CCORAL), pursue } \\
\text { closer collaboration with the Caribbean Public Health Agency (CARPHA, which } \\
\text { includes the former CEHI), expand its youth focused public education work and } \\
\text { welcome at least one new beneficiary country [Martinique]" (CCCCC, 2015a, } \\
\text { online). }\end{array}$ & $\nabla$ \\
\hline
\end{tabular}




\begin{tabular}{|c|c|c|c|}
\hline SUB-COMPONENT & INDICATOR & EVIDENCE & RATING \\
\hline 3. Needs and goals & $\begin{array}{l}\text { 7. The project documents contain } \\
\text { evidence that the project/program } \\
\text { fills an existing need with relation } \\
\text { to climate change adaptation. }\end{array}$ & 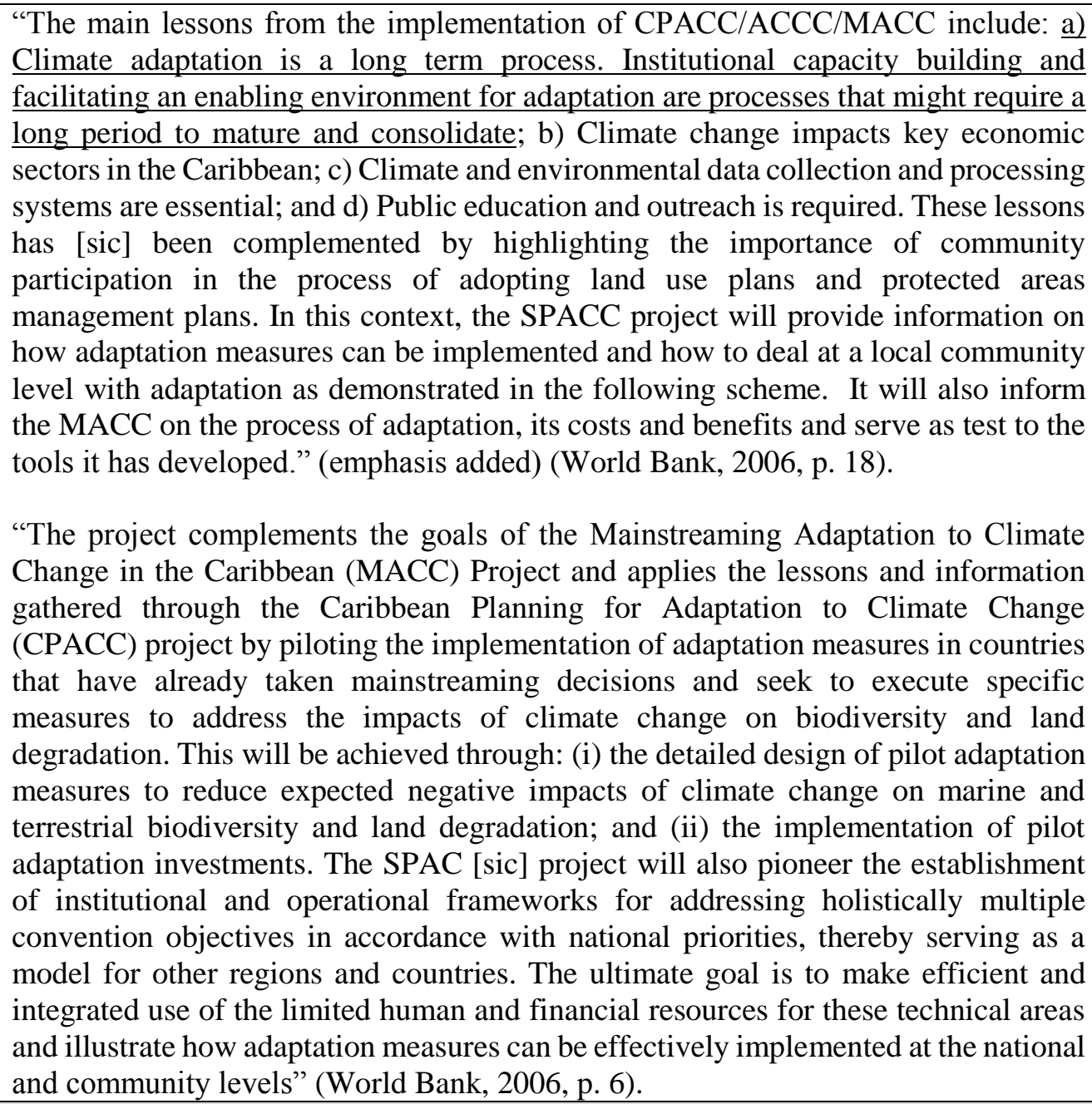 & $\nabla$ \\
\hline & $\begin{array}{l}\text { 8. The project/program's adaptation } \\
\text { components could be considered } \\
\text { "transformational (i.e. the } \\
\text { project/program focusses on } \\
\text { "larger, more profound system } \\
\text { changes" and requires a } \\
\text { "paradigm shift" in the way it is } \\
\text { framed and implemented). }\end{array}$ & & \\
\hline
\end{tabular}




\begin{tabular}{|c|c|c|c|}
\hline SUB-COMPONENT & INDICATOR & $\begin{array}{l}\text { EVIDENCE } \\
\end{array}$ & RATING \\
\hline & $\begin{array}{l}\text { 9. Climate change adaptation is a } \\
\text { goal of the project/program. }\end{array}$ & $\begin{array}{l}\text { "The Global Environment Objective [GEO] [of the project] was to produce } \\
\text { knowledge that would be of global value on how to implement adaptation measures } \\
\text { in small island states, which could be applicable to other countries in the region, and } \\
\text { in the world, even if they were not participating in the project" (World Bank, 2012, } \\
\text { p. vi). } \\
\text { The project development objective (PDO) "was to support efforts by Dominica, Saint } \\
\text { Lucia and St. Vincent and the Grenadines to implement specific (integrated) pilot } \\
\text { adaptation measures addressing primarily, the impacts of climate change on their } \\
\text { natural resources base, focused on biodiversity and land degradation along coastal } \\
\text { and near-coastal areas. They were achieved through: (i) the detailed design of pilot } \\
\text { adaptation measures to reduce expected negative impacts of climate change on } \\
\text { biodiversity and land degradation; and (ii) the implementation of pilot adaptation } \\
\text { investments. Reducing these impacts would primarily result in protection of } \\
\text { biodiversity and prevention of land degradation but would also induce economic } \\
\text { benefits in the tourism, fisheries, agriculture and forestry sectors. It would also help } \\
\text { maintain the resource base upon which these economic activities rely, promoting a } \\
\text { climate resilient sustainable development" (emphasis added) (World Bank, 2012, p. } \\
\text { vi). }\end{array}$ & 口 \\
\hline & $\begin{array}{l}\text { 10. The project/program's goals } \\
\text { reflect the long-range impacts of } \\
\text { climate change. }\end{array}$ & $\begin{array}{l}\text { "Figure below [figure actually missing from document!] presents a description of the } \\
\text { long-term adaptation process, undertaken through the Bank and emphasizing the } \\
\text { relationship between previous work under CPACC and ACCC, the ongoing MACC } \\
\text { Project, and the SPACC Project. It also indicates that this is a long-term and } \\
\text { continuous effort to face what constitutes an ever-growing threat to the sustainability } \\
\text { of the region. Together, these activities correspond to the stages of adaptation } \\
\text { envisioned under the Conference of Parties' (COP's) guidance to the GEF. CPACC } \\
\text { (Stage I) focused on building awareness to climate change issues among public } \\
\text { officials and the political sector, and initiating the process of strengthening the } \\
\text { knowledge base. MACC (Stage II) supports further capacity building, facilitates the } \\
\text { formulation of an enabling environment for adaptation and the formulation of } \\
\text { adaptation measures. SPACC will fund specific adaptation measures" (World Bank, } \\
2006, \text { p. 17). } \\
\text { *Also see 1.1. (a) } \rightarrow \text { underline } \\
\text { "Economic analyses of proposed adaptation measures will be undertaken as part of } \\
\text { the design process (Component 1). In the economic analysis consideration will be } \\
\text { given to the long term character of the expected benefits and costs. Community, }\end{array}$ & $\nabla$ \\
\hline
\end{tabular}




\begin{tabular}{|c|c|c|c|}
\hline SUB-COMPONENT & INDICATOR & EVIDENCE & RATING \\
\hline & & $\begin{array}{l}\text { national and sectoral benefits will be identified and quantified as part of the analysis. } \\
\text { An incremental cost analysis and an accounting of local and global benefits will also } \\
\text { be included. A financial analysis will be conducted as part of the selection process } \\
\text { for site specific adaptation measures, which will guide the decision-making process } \\
\text { for the identification of appropriate and economic efficient interventions. During } \\
\text { project implementation data will be gathered to assess actual benefits and costs of } \\
\text { pilot measures" (emphasis added) (World Bank, 2006, p. 23). } \\
\text { "The governments are involved in the adaptation measures identification process, the } \\
\text { governments confirmed to provide in kind or in cash contributions. However, MACC } \\
\text { continues supporting in parallel the enabling environment process and SPAC will } \\
\text { further strengthen the sensitization process. Also, selected adaptation initiatives will } \\
\text { complement ongoing or planned government programs addressing the key sectors } \\
\text { vulnerable to climate change. The project will add on to these government activities } \\
\text { by incorporating long term climate change considerations in planning, designing and } \\
\text { implementing the specific actions. Such a design guarantees mainstreaming climate } \\
\text { change consideration in the selected sectors" (emphasis added) (World Bank, 2006, } \\
\text { p. 47). }\end{array}$ & \\
\hline & $\begin{array}{l}\text { 11. The project/program's objectives } \\
\text { relating to climate change } \\
\text { adaptation are specific, } \\
\text { measurable, achievable, realistic } \\
\text { and time-bound (SMART). }\end{array}$ & $\begin{array}{l}\text { The project has } 15 \text { indicators (after re-structuring): } \\
\text { Dominica } \\
\text { Indicator 1: "At least one Park Management Plan for Morne Diablotin National Park } \\
\text { (MDNP) and /or Morne Trois Pitons National Park (MTPNP) updated with climate } \\
\text { change issues and submitted to Cabinet after review by the Secretary of Agriculture" } \\
\text { (World Bank, 2012, p. vi). } \\
\text { Indicator 2: "The Ministry of Agriculture creates and maintains a comprehensive } \\
\text { database of key ecological variables useful for Park Management" (World Bank, } \\
\text { 2012, p. vii). } \\
\text { Indicator 3: "The Ministry of Agriculture and Forestry installs at least one new } \\
\text { meteorological station in each of the two Parks and uses information from them for } \\
\text { National Park management and/or agriculture planning" (World Bank, 2012, p. vii). } \\
\text { Indicator 4: "The Ministry of Agriculture gains capacity to manage water stresses } \\
\text { related to climate change through extrapolating useful lessons from an irrigation pilot } \\
\text { for the communities of Colihaut, Dublanc and Bioche" (World Bank, 2012, p. viii). }\end{array}$ & $\diamond$ \\
\hline
\end{tabular}




\begin{tabular}{|c|c|c|c|}
\hline SUB-COMPONENT & INDICATOR & EVIDENCE & RATING \\
\hline & & $\begin{array}{l}\text { St. Lucia } \\
\text { Indicator 5: "Results from the implementation of Vieux Fort rainwater harvesting and } \\
\text { waste water treatment pilot documented \& disseminated by the Planning Ministry } \\
\text { through a TN and a workshop for government, private sector and nonprofit [sic] } \\
\text { stakeholders" (World Bank, 2012, p. viii). } \\
\text { Indicator 6: "Vieux Fort rain water harvesting system reduces the consumption of } \\
\text { 3,000 cubic meters per year of potable water from the water utility" (World Bank, } \\
\text { 2012, p. ix). } \\
\text { Indicator 7: "The Ministry of Physical Planning and Environment submits for Cabinet } \\
\text { approval a decree to enforce rain water harvesting on new touristic activities" (World } \\
\text { Bank, 2012, p. ix). } \\
\text { Indicator 8: "Successful Vieux Fort waste water treatment system contributes to } \\
\text { reduce organic load to the coastal ecosystems in the Pointe Sable Environmental } \\
\text { Protection Area by canceling [sic] actual waste water sewerage outflow into the } \\
\text { coast" (World Bank, 2012, p. ix). } \\
\text { Indicator 9: "Information campaign implemented by the Ministry of Physical } \\
\text { Planning and Environment to disseminate the lessons of the Marchand building pilot" } \\
\text { (World Bank, 2012, p. x). } \\
\text { St. Vincent and the Grenadines } \\
\text { Indicator 10: "Institutional viability of Bequia water desalination \& distribution } \\
\text { system is demonstrated by an operative, adequately staffed Central Water \& Sewage } \\
\text { Authority office for the collection of consumer fees, and operation \& maintenance of } \\
\text { the system" (World Bank, 2012, p. x). } \\
\text { Indicator 11: "Technical viability of Bequia desalination, water distribution and } \\
\text { renewable energy pilot is demonstrated by an operative desalination plant producing } \\
50 \text { m3 per day and an operative renewable energy device producing an average of } \\
10,000 \text { kWh per month" (World Bank, 2012, p. xi). } \\
\text { Indicator 12: "Financial viability of Bequia desalination, water distribution \& } \\
\text { renewable energy pilot is demonstrated by a financing mechanism including tariffs, }\end{array}$ & \\
\hline
\end{tabular}




\begin{tabular}{|c|c|c|c|}
\hline SUB-COMPONENT & INDICATOR & $\begin{array}{l}\text { EVIDENCE } \\
\end{array}$ & RATING \\
\hline & & $\begin{array}{l}\text { budgetary contributions and a renewable energy source to cover maintenance \& offset } \\
\text { incremental costs" (World Bank, 2012, p. xi). } \\
\text { Indicator 13: "The Ministry of Health and Environment gains capacity to manage } \\
\text { water stresses related to climate change through the extraction of useful lessons from } \\
\text { Bequia pilot" (World Bank, 2012, p. xii). } \\
\text { GEO Indicators } \\
\text { Indicator 14: "Global Learning Value. Lessons learnt by the CCCCC are } \\
\text { disseminated through technical notes" (World Bank, 2012, p. xii). } \\
\text { Indicator 15: "University of West Indies receives from the Meteorological Research } \\
\text { Institute of Japan, useful climate modeling data to enhance its regional climate model } \\
\text { and makes use of the results in research and teaching" (World Bank, 2012, p. xiii). } \\
\text { "The design of the M\&E, as reflected in the results framework, did not always } \\
\text { establish clear links between the objectives, outputs and indicators. Initial monitoring } \\
\text { was hard to perform (for example, an indicator related to the number of nesting } \\
\text { parrots in a Dominica National Park). Once the Project was restructured, the } \\
\text { indicators became easier to measure and to report to, thus allowing the results } \\
\text { framework to be used as the instrument to evaluate on-the-ground progress. Quantity } \\
\text { and quality of information varies between the three participating countries, with St. } \\
\text { Lucia undergoing a very detailed reporting discipline while St. Vincent and Dominica } \\
\text { lagged behind" (World Bank, 2012, p. 13). }\end{array}$ & \\
\hline & $\begin{array}{l}\text { 12. Member Countries were involved } \\
\text { in developing the climate change } \\
\text { adaptation components of the } \\
\text { project/program. }\end{array}$ & $\begin{array}{l}\text { Government endorsement letters state that the project was developed in close } \\
\text { collaboration with the CCCCC and the WB. They also state that the project was } \\
\text { developed in accordance with national development and environmental priorities e.g. } \\
\text { the letter from the SVG GEF Focal Point stated, "The project is designed in } \\
\text { accordance with national development environmental priorities as defined in "St. } \\
\text { Vincent and the Grenadines' draft Climate Change Policy and Implementation Plan" } \\
\text { and St. Vincent and the Grenadines Biodiversity Strategy and Action Plan", which } \\
\text { has been approved by Cabinet" (GEF, 2013, online). } \\
\text { This process however proved to be useful as different actors in the participating } \\
\text { countries engaged in the decision making process during the design phase, and } \\
\text { obtained significant insights and capacities to improve the quality of interventions }\end{array}$ & $\diamond$ \\
\hline
\end{tabular}




\begin{tabular}{|c|c|c|c|}
\hline SUB-COMPONENT & INDICATOR & EVIDENCE & RATING \\
\hline & & $\begin{array}{l}\text { moving forward, and be better prepared to scale up successful activities in the future" } \\
\text { (World Bank, 2012, p. 9). } \\
\text { "Although the Grant Agreement stipulated that participating countries should provide } \\
\text { resources for national coordination, financial shortages generated in part by the } \\
\text { international financial crisis prevented this from happening (with the notable } \\
\text { exception of Saint Lucia). The implementing agency, however, stepped up to this } \\
\text { challenge and with their own funds hired technical coordinators for Saint Vincent and } \\
\text { Dominica. In general terms, however, these coordinators did not have the authority } \\
\text { to speak on behalf of government" (World Bank, 2012, p. 9). }\end{array}$ & \\
\hline 4. Scope & $\begin{array}{l}\text { 5. The project/program addresses } \\
\text { multiple climate or climate- } \\
\text { induced vulnerabilities (e.g. } \\
\text { vulnerability to sea-level rise, } \\
\text { increased sea surface and air } \\
\text { temperature, changing rainfall } \\
\text { patterns etc.). }\end{array}$ & $\begin{array}{l}\text { Project rationale, objectives, outputs/outcomes, and activities } \downarrow \\
\text { "Climate change threatens the stability and integrity of marine and insular } \\
\text { systems. Small Island Developing States (SIDS) have been recognized as most } \\
\text { vulnerable to the impacts of climate change, and as requiring greater attention by the } \\
\text { international community at large. The Third Assessment Report (TAR) of IPCC has } \\
\text { documented the anticipated trends in sea level rise (SLR), increases in sea surface } \\
\text { temperature, as well as changes in the precipitation cycle and patterns of extreme } \\
\text { events, among the impacts that may severely affect the sustainable development } \\
\text { prospects of Caribbean SIDS. The Report also highlights the severity of their } \\
\text { expected climatic shifts, the low level of their economic development which restricts } \\
\text { their ability to cope with expected changes without great economic stress" } \\
\text { (underlining added) (World Bank, 2006, p. 2). } \\
\text { "The Organization of Eastern Caribbean States (OECS) region to which the } \\
\text { three participating countries belong is characterized by a rich biodiversity } \\
\text { endowment, which, in combination with its isolation from other areas has resulted } \\
\text { in relatively high rates of national and regional endemism" (World Bank, 2006, p. 2). } \\
\text { "Climate change will affect the physical and biological characteristics of the } \\
\text { Caribbean Sea and their coastal areas, modifying their ecosystem structure and } \\
\text { functioning" (World Bank, 2006, p. 3). } \\
\text { "Also, in near-shore marine and coastal areas, many wetlands and coastal forests will } \\
\text { be affected by changes in sea level and storm surges" (World Bank, 2006, p. 3). }\end{array}$ & $\square$ \\
\hline
\end{tabular}




\begin{tabular}{|c|c|c|c|}
\hline SUB-COMPONENT & INDICATOR & $\begin{array}{l}\text { EVIDENCE } \\
\end{array}$ & RATING \\
\hline & & $\begin{array}{l}\text { "Climate variability and intensification of hurricanes pose a significant threat } \\
\text { to the sustainable development of Small Island Developing Sates" (World Bank, } \\
2006, \text { p. 3). } \\
\text { "The largest category of impacts is the loss of land, tourism infrastructure, housing, } \\
\text { other buildings, and infrastructure due to sea-level rise" (World Bank, 2006, p. 4). }\end{array}$ & \\
\hline & $\begin{array}{l}\text { 6. The project/program addresses } \\
\text { multiple non-climate-induced } \\
\text { vulnerabilities (e.g. poverty, } \\
\text { deforestation etc.). }\end{array}$ & $\begin{array}{l}\text { "The Report also highlights the severity of their expected climatic shifts, the low level } \\
\text { of their economic development which restricts their ability to cope with expected } \\
\text { changes without great economic stress" (World Bank, 2006, p. } 2 \text { ). } \\
\text { "The region economic activity is very dependent on a natural resource base } \\
\text { which is highly vulnerable to climate change impacts. The CARICOM countries } \\
\text { are highly dependent on natural resources and are thus very vulnerable to the impacts } \\
\text { of climate change. The potential economic impact of climate change on the } \\
\text { CARICOM countries is estimated at between US } \$ 1.4 \text { and } \$ 9.0 \text { billion for the impacts } \\
\text { that could be estimated assuming no adaptation to climate change. The wide range } \\
\text { for the estimate of potential economic impacts is due more to the uncertainty relating } \\
\text { to the values and assumptions used than to the uncertainty about climate change. In } \\
\text { the low scenario the total impact averages about } 5.6 \text { percent of the gross domestic } \\
\text { product (GDP), ranging from } 3.5 \text { percent in Trinidad and Tobago to } 16 \text { percent in } \\
\text { Guyana. In the high scenario the total impact averages over } 34 \text { percent of GDP, } \\
\text { ranging from } 22 \text { percent in Trinidad and Tobago to } 103 \text { percent in Guyana" (World } \\
\text { Bank, 2006, pp. 3-4). } \\
\text { *Includes a table called "Vulnerability of Ecosystem Services and } \\
\text { Implications for Economic Activity in small island states in the Caribbean" } \\
\text { (World Bank, 2006, pp. } 4-5 \text { ). }\end{array}$ & 田 \\
\hline $\begin{array}{l}\text { 5. Logic, design and } \\
\text { adequacy }\end{array}$ & $\begin{array}{l}\text { 3. The logic/design of the } \\
\text { project/program's climate change } \\
\text { adaptation components is } \\
\text { evidence-based, in the context of } \\
\text { SIDS. }\end{array}$ & $\begin{array}{l}\text { Illustrations of the "lack of clear national counterparts that link responsibility with } \\
\text { authority" include: "(i) the development of the desalination plant in Bequia, St. } \\
\text { Vincent involing [sic] two basic elements; installing a plant to provide freshwater for } \\
\text { the target community of Paget Farm, and the installation of a renewable power } \\
\text { generation facility to reduce operation costs. In theory, this approach would generate } \\
\text { revenue to support maintenance of the plant by selling power back to the national }\end{array}$ & $\diamond$ \\
\hline
\end{tabular}

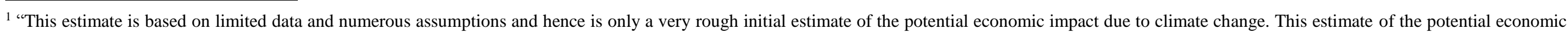

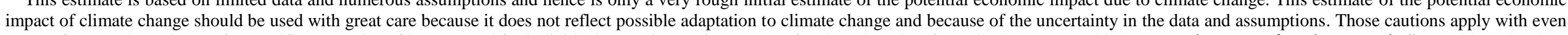

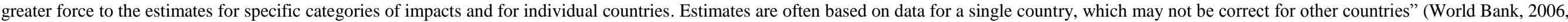
pp. 3-4). 


\begin{tabular}{|c|c|c|c|}
\hline SUB-COMPONENT & INDICATOR & EVIDENCE & RATING \\
\hline & & $\begin{array}{l}\text { grid. While in theory the idea is excellent and technically sound, missing from the } \\
\text { design was the inclusion of a mechanism to ensure that the policies of the national } \\
\text { power company (VINLEC) would be changed to allow the purchase of excess power. } \\
\text { Additionally, binding arrangements with the national water authority (CWSA) for } \\
\text { operation and maintenance of the plant were also left to the implementation phase. A } \\
\text { positive aspect to this is that the Project served as a catalyst to start the dialogue on } \\
\text { those issues and anticipate some of the shortcomings that will appear when the } \\
\text { approach is scaled up to the rest of the island and/or to other islands" (emphases } \\
\text { added) (World Bank, 2012, pp. 9-10). } \\
\text { "Similarly, in Dominica, the Project funded the installation of a pilot irrigation system } \\
\text { supporting farmers engaged in alternative agriculture projects, notably greenhouse } \\
\text { agriculture. In this case, the Project design was focused on the contribution to } \\
\text { agricultural alternatives without considering the operational requirements of a } \\
\text { community irrigation system. As irrigation is somewhat new to Dominica, no national } \\
\text { mechanisms exist to empower communities to get organized, operate and maintain } \\
\text { such systems. This requires the formation of a water association and the } \\
\text { empowerment of the association to charge user fees, contract for maintenance and } \\
\text { manage water distribution within the user community. While the pilot is contributing } \\
\text { to help steer the dialogue in Dominica towards the organization of water user } \\
\text { associations, these are not yet in place due to gaps in existing regulations. These gaps } \\
\text { have been identified, and are currently being addressed, which has been an } \\
\text { unintended positive aspect of the activity" (World Bank, 2012, p. 10). }\end{array}$ & \\
\hline & $\begin{array}{l}\text { 4. The project documents contain } \\
\text { evidence that the logic/design of } \\
\text { the project/program's climate } \\
\text { change adaptation components is } \\
\text { an effective means to achieve its } \\
\text { objectives. }\end{array}$ & $\begin{array}{l}\text { "Project design lacked specificity. The description of the Components was general in } \\
\text { nature and actual activities were largely determined by the result of studies and } \\
\text { designs prepared during the Project's implementation. While this is not necessarily a } \\
\text { problem in large projects, the funding levels appropriated under this Project were } \\
\text { insufficient to take this kind of approach. The Project had to be restructured, and two } \\
\text { out of the initial seven pilot interventions were dropped because of land tenure issues, } \\
\text { not anticipated during preparation. Most of the core time of Project implementation } \\
\text { was devoted to agreeing on final designs, finalizing them, and preparing bidding } \\
\text { documents, instead of improving the operation arrangements and performing } \\
\text { monitoring of the different pilots. This process however proved to be useful as } \\
\text { different actors in the participating countries engaged in the decision making process } \\
\text { during the design phase, and obtained significant insights and capacities to improve } \\
\text { the quality of interventions moving forward, and be better prepared to scale up } \\
\text { successful activities in the future" (World Bank, 2012, p. 9). }\end{array}$ & $\diamond$ \\
\hline
\end{tabular}




\begin{tabular}{|c|c|c|c|}
\hline SUB-COMPONENT & INDICATOR & EVIDENCE & RATING \\
\hline & & $\begin{array}{l}\text { "Lack of clear national counterparts that link responsibility with authority. A } \\
\text { significant issue inherent in Project design was the effectiveness of the } \\
\text { implementation arrangements. In all cases, specific national line agencies were } \\
\text { engaged to support Project development through the use of a national coordinator. } \\
\text { Although the Grant Agreement stipulated that participating countries should provide } \\
\text { resources for national coordination, financial shortages generated in part by the } \\
\text { international financial crisis prevented this from happening (with the notable } \\
\text { exception of Saint Lucia). The implementing agency, however, stepped up to this } \\
\text { challenge and with their own funds hired technical coordinators for Saint Vincent and } \\
\text { Dominica. In general terms, however, these coordinators did not have the authority } \\
\text { to speak on behalf of government. Critical decisions required to ensure the success of } \\
\text { the Project were diffused through participating agencies with no clear mechanism for } \\
\text { getting to definitive decisions and binding agreements. As a regional technical } \\
\text { advisory agency, CCCCC is limited in its ability to affect national decisions. It has to } \\
\text { be noted, however, that once the Project was restructured, and its final scope better } \\
\text { defined, the implementation phase sped up significantly and the Project ultimately } \\
\text { met its goals" (World Bank, 2012, p. 9). }\end{array}$ & \\
\hline 6. Resources & $\begin{array}{l}\text { 6. Staff members are } \\
\text { exclusively } \\
\text { project/program. }\end{array}$ & $\begin{array}{l}\text { The Project was "executed through a Project Manager contracted by, and based at the } \\
\text { Centre and a National Coordinator, also contracted by the Centre, but operating from } \\
\text { the Environment Section of this Ministry [of Physical Development, Environment } \\
\text { and Housing, St. Lucia]" (The Voice, 2008, online). But the Project Manager [Mr } \\
\text { Winston Bennett] was managing several projects at the same time: "Prior to joining } \\
\text { CROSQ, Mr. Bennett was employed as Project Coordinator/Technical Leader for the } \\
\text { CARICOM Climate Change Centre (CCCCC) and the CARICOM Secretariat where } \\
\text { he managed several projects including the Special Program for Adaptation to Climate } \\
\text { Change (SPACC), funded by the World Bank" (emphasis added) (CROSQ, 2011, pp. } \\
\text { 1-2). } \\
\text { Also to note: } \\
\text { "While technically experienced in funds management and contract execution, } \\
\text { CCCCC encountered difficulties with the country counterparts early in Project } \\
\text { implementation largely related to the organization and management of the Project. } \\
\text { Weaknesses became apparent early in the process notably with the technical } \\
\text { management team provided by CCCCC and the requirement to operate through a } \\
\text { system of country project coordinators. These required political negotiations with the } \\
\text { respective countries to ensure effective project coordinators were appointed. The } \\
\text { diffusion of authority between the participating country agencies, Project }\end{array}$ & 凶 \\
\hline
\end{tabular}




\begin{tabular}{|c|c|c|c|}
\hline SUB-COMPONENT & INDICATOR & EVIDENCE & RATING \\
\hline & & $\begin{array}{l}\text { coordinators and CCCCC created a significant impediment to implementation as no } \\
\text { central point of authority at the national level was available to make decisions with } \\
\text { respect to specific interventions or implementation activities on the ground. This lack } \\
\text { of clear decision authority was particularly problematic in St. Vincent and Dominica. } \\
\text { In St. Lucia, the problem was no less significant but was generally overcome due to } \\
\text { the management skills of the coordinator and the participation of government } \\
\text { agencies not originally involved in Project design. With respect to CCCCC, as a } \\
\text { regional agency their strengths relate to funds management and general technical } \\
\text { assistance on a macro scale. The management team selected to oversee the Project } \\
\text { lacked the technical support required to implement specific activities at the country } \\
\text { level. Additionally, with much of the operational responsibility placed on the national } \\
\text { coordinators, CCCCC's ability to directly influence implementation and decisions } \\
\text { was limited, affecting the efficiency of Project execution" (emphasis added) (World } \\
\text { Bank, 2012, p. 11). }\end{array}$ & \\
\hline & $\begin{array}{l}\text { 7. The project/program team } \\
\text { includes staff members with } \\
\text { qualifications and experience in } \\
\text { climate change adaptation. }\end{array}$ & $\begin{array}{l}\text { Project Manager-Mr Winston Bennett: } \\
\text { "Mr Bennett holds a Bachelor of Science (BSc) in Industrial Engineering from the } \\
\text { University of the West Indies, St. Augustine Campus in Trinidad and Tobago and an } \\
\text { MBA from McGill University in Canada. He also has an Associate Degree with } \\
\text { combined Majors of Mathematics, Chemistry and Biology and has extensive } \\
\text { experience in project management, among other areas" (CROSQ, 2011, p. 1). } \\
\text { While at CCCCC, Mr Bennett also managed the following projects: "Capacity for } \\
\text { Adaptation to Climate Change (ECACC, [2007-2011]), funded by the Department } \\
\text { for International Development (DFID); and the International Hydrological Program } \\
\text { (HIP) Adoption Measures to Climate Change Impacts on Coastal Aquifer Systems in } \\
\text { the Caribbean project [2009-2011], funded by UNESCO. During his tenure at } \\
\text { CCCCC, he was also responsible for providing overall financial and administrative } \\
\text { management and technical implementation assistance for the Mainstreaming for } \\
\text { Adaptation to Climate Change Project (MACC)" (CROSQ, 2011, p. 2). } \\
\text { "Mr. Bennett's [employment] portfolio also includes his holding the posts of: } \\
\text { Director of the Water and Wastewater Sector of the Public Utilities Commission in } \\
\text { Belize; Executive Director of the Belize Social Investment Fund (BSIF)" (CROSQ, } \\
\text { 2011, p. 2). } \\
\text { Also to note: }\end{array}$ & $\diamond$ \\
\hline
\end{tabular}




\begin{tabular}{|c|c|c|c|}
\hline SUB-COMPONENT & INDICATOR & EVIDENCE & RATING \\
\hline & & $\begin{array}{l}\text { In a February } 2011 \text { procurement notice for the Procurement and Installation of } \\
\text { Photovoltaic System for Bequia, St. Vincent and the Grenadines (SPACC-ICB-SV- } \\
\text { 03), Mr Earl Green was identified as a Project Manager (see World Bank, 2011). }\end{array}$ & \\
\hline & $\begin{array}{l}\text { 8. The project/program team } \\
\text { includes staff members with } \\
\text { qualifications and experience in } \\
\text { project/program management. }\end{array}$ & $\begin{array}{l}\text { Project Manager - Mr Winston Bennett: } \\
\text { Mr Bennett was "Financial Controller of the Water and Sewage Authority (WASA) } \\
\text { in Belize. He also held, inter alia, positions of Manager of Customer Relations, Public } \\
\text { Relations and Business Development, Project Development Specialist/Senior } \\
\text { Economist, and Senior Project Officer (Industry)/Industrial Project Officer at various } \\
\text { organizations [sic] throughout his employment" (CROSQ, 2011, p. 2). } \\
\text { Also to note: } \\
\text { "Throughout the Project life the CCCCC was staffed with a seasoned Finance } \\
\text { Professional with no turn over" (World Bank, 2012, p. 14). }\end{array}$ & $\nabla$ \\
\hline & $\begin{array}{l}\text { 9. The project documents contain } \\
\text { evidence that there are sufficient } \\
\text { staff members to achieve the } \\
\text { project/program objectives. }\end{array}$ & & \\
\hline & $\begin{array}{l}\text { 10. The project documents contain } \\
\text { evidence that there is sufficient } \\
\text { funding for the project/program's } \\
\text { climate change adaptation } \\
\text { components. }\end{array}$ & $\begin{array}{l}\text { "Inappropriate levels of funding: The Project initially included US\$200,000 to } \\
\text { conduct identification, evaluation, selection and design of adaptation measures } \\
\text { (Component 1). However, these tasks required greater levels of effort, including } \\
\text { frequent trips by CCCCC from Belize to the PCs. The Project required highly } \\
\text { specialized studies with participation of cutting-edge institutions, such as the } \\
\text { hurricane wind study, performed for Saint Lucia, or the preparation of specialized } \\
\text { designs and technical specifications for the desalination plant and alternative power } \\
\text { generation in St. Vincent. Resources allocated to these tasks were insufficient, and a } \\
\text { restructuring had to be done to reallocate more resources from elsewhere. Regarding } \\
\text { the actual on-the-ground pilot projects, the budget initially allocated was US } \$ 1.5 \mathrm{M} \text {. } \\
\text { Unfortunately, there was no consideration for design requirements or how those } \\
\text { resources would be distributed amongst the PCs. Seven pilot projects were supposed } \\
\text { to be financed with those funds, but it became clear that significantly more resources } \\
\text { were needed" (World Bank, 2012, pp. 11-12). } \\
\text { "Financial crisis affected some programmed activities: The international financial } \\
\text { crisis impacted some of the planned activities. The PCs, who were largely dependent } \\
\text { on tourism, were significantly impacted, and as a result, failed to provide their } \\
\text { expected counterpart funding. To promote continued country participation and to }\end{array}$ & $\boldsymbol{x}$ \\
\hline
\end{tabular}




\begin{tabular}{|c|c|c|c|}
\hline SUB-COMPONENT & INDICATOR & EVIDENCE & RATING \\
\hline & & $\begin{array}{l}\text { comply with requirements for country contributions, the Project was restructured to } \\
\text { include the provision of in-kind contributions. The IUCN, whose contribution under } \\
\text { component } 3 \text { was essential to lead, coordinate and execute the different activities of } \\
\text { this component, suffered some financial hardships that forced them to withdraw from } \\
\text { the Project. This component was downscaled to a smaller but still useful number of } \\
\text { activities. In St. Vincent, the Government's contribution was focused on financing } \\
\text { the water distribution system at the Paget Farm community, while the Project would } \\
\text { finance the desalination plant and the sustainable energy source. This was reflected } \\
\text { in a memorandum of understanding between CCCCC and the Government, and at } \\
\text { some point, cash sources were actually inscribed in the national budget for this } \\
\text { purpose. However, this contribution never materialized and, up to date, the CCCCC } \\
\text { has had to find additional sources of funds to cover the shortfall. With these new } \\
\text { funds, the main pipes and connections would be financed, while household service } \\
\text { connections are to be financed through the United States Agency for International } \\
\text { Development (USAID) project that is currently (May 2012) being prepared" (World } \\
\text { Bank, 2012, p. 12). }\end{array}$ & \\
\hline $\begin{array}{ll}\text { 7. Technical } \\
\text { efficiency }\end{array}$ & $\begin{array}{l}\text { 2. The project documents contain } \\
\text { evidence that the project/program } \\
\text { provides value for money (cost } \\
\text { vs. outputs). }\end{array}$ & $\begin{array}{l}\text { "The Project was complex and ambitious given the funds available. While important } \\
\text { on a regional scale, the Project focused on pilot activities designed to address issues } \\
\text { on a national scale. The blending of the national and international perspectives } \\
\text { resulted in a Project that was extremely ambitious considering the level of funding } \\
\text { available and the complexity of implementation. Moreover, the Project's activities } \\
\text { spanned from biodiversity protection and management of National Parks to } \\
\text { infrastructure works for building retrofitting, renewable energy production, } \\
\text { meteorological monitoring or climate change modeling and scenario generation. This } \\
\text { variety of interventions would have required the participation of many different types } \\
\text { of expertise both in-country and at the implementing agency level. These challenges } \\
\text { were recognized and addressed by engaging experts on these different topics, but also } \\
\text { required extra time and resources" (World Bank, 2012, p. 9). }\end{array}$ & $\diamond$ \\
\hline 8. Implementation & $\begin{array}{l}\text { 2. The project/program's climate } \\
\text { change adaptation components } \\
\text { are implemented, as proposed. }\end{array}$ & $\begin{array}{l}\text { "The project was restructured on September 14, 2010. Two out of the seven pilot } \\
\text { projects were cancelled, resulting in a reduction of the total scope of the Project. The } \\
\text { restructuring also included some reallocation of proceeds amongst components to } \\
\text { reflect higher costs in design (Component } 1 \text { ) and lower costs in Component } 3 \text {, and } \\
\text { some modifications of the financing plan to reflect shortages of funds by the } \\
\text { participating countries, IUCN, and increased resources provided by CCCCC" (World } \\
\text { Bank, 2012, p. 8). } \\
\text { "The restructuring of the Project involved changes in the outcome indicators in order } \\
\text { to more accurately reflect the Project's objectives and the nature of the interventions; }\end{array}$ & 可 \\
\hline
\end{tabular}




\begin{tabular}{|c|c|c|c|}
\hline SUB-COMPONENT & INDICATOR & EVIDENCE & RATING \\
\hline & & $\begin{array}{l}\text { modifications to the Project activities in St. Vincent and the Grenadines (cancelation } \\
\text { of } 2 \text { pilots); adjustment of the disbursement categories to finance workshops and } \\
\text { operating costs; modification of the financing plan to close the financing gap created } \\
\text { by changes in the co-financing resources; and reallocation of the proceeds of the GEF } \\
\text { Trust Fund Grant" (World Bank, 2012, p. 8). }\end{array}$ & \\
\hline \multirow[t]{2}{*}{$\begin{array}{l}\text { 9. Monitoring and } \\
\text { evaluation }\end{array}$} & $\begin{array}{l}\text { 4. The project/program is internally } \\
\text { monitored and evaluated. }\end{array}$ & See Paragraph 1 in 7.2 below. & $\diamond$ \\
\hline & $\begin{array}{l}\text { 5. The project/program is externally } \\
\text { monitored and evaluated. }\end{array}$ & $\begin{array}{l}\text { "Reporting, monitoring and evaluation included World Bank supervision, which was } \\
\text { typically undertaken together with the implementing agency, CCCCC; quarterly } \\
\text { IUFRs (Interim Unaudited Financial Reports) including financial reports and } \\
\text { procurement plans; annual work plans and reports; a mid-term review (MTR) } \\
\text { conducted jointly by World Bank and CCCCC teams; and the conduct of annual } \\
\text { audits. Regular audio-conferences between CCCCC, technical coordinators and Bank } \\
\text { team took place" " (World Bank, 2012, p. 13). } \\
\text { "The mid-term review (September 2010) included a thorough analysis of the project } \\
\text { implementation, identifying the constraints and recommending the restructuring of } \\
\text { the project, while leaving the philosophy of the components, their distribution and } \\
\text { flow unchanged. The restructuring involved dropping two of seven pilot projects, } \\
\text { reallocating project proceeds and changes in the project performance indicators to } \\
\text { better reflect the objective of piloting adaptation measures while generating global } \\
\text { knowledge and ground experience to be replicated in other countries and regions. } \\
\text { Since two pilots were canceled, the overall scope of the Project was reduced. } \\
\text { However, SPACC original objectives did not change after the restructuring" (World } \\
\text { Bank, 2012, p. 8). }\end{array}$ & $\nabla$ \\
\hline 10. Sustainability & $\begin{array}{l}\text { 2. There are sustained outputs from } \\
\text { the project/program. }\end{array}$ & & \\
\hline & & 3. Output Effectiveness & \\
\hline 3. Goal attainment & $\begin{array}{l}\text { 2. There is evidence in the most } \\
\text { recent annual report or evaluation } \\
\text { that the climate change } \\
\text { adaptation-related objectives of } \\
\text { the organisation are being } \\
\text { achieved. }\end{array}$ & *Annual reports not available. & $(\mathrm{NE})$ \\
\hline $\begin{array}{l}\text { 4. Research and } \\
\text { knowledge } \\
\text { management }\end{array}$ & $\begin{array}{l}\text { 1. The organisation produces and/or } \\
\text { publishes research that is relevant }\end{array}$ & $\begin{array}{l}\text { The Centre "is repository and clearing house for regional climate change information } \\
\text { and data" (CCCCC, 2015c, online). }\end{array}$ & $\diamond$ \\
\hline
\end{tabular}




\begin{tabular}{|c|c|c|c|}
\hline SUB-COMPONENT & INDICATOR & EVIDENCE & RATING \\
\hline & $\begin{array}{l}\text { to climate change adaptation at } \\
\text { least annually. }\end{array}$ & $\begin{array}{l}\text { "The Caribbean Community Climate Change Centre's (CCCCC) Regional } \\
\text { Clearinghouse Database is the region's premier repository of information and data on } \\
\text { climate change specific to the region. This dedicated climate change resource was } \\
\text { first explored over a decade ago during the course of the Caribbean Planning for } \\
\text { Adaptation to Climate Change (CPACC) project (1997 to 2001), but the current } \\
\text { iteration was spurred by a CDB project grant (2010) for a new CCCCC website and } \\
\text { information portal focused on gathering, disseminating and exchanging information } \\
\text { and data on climate change. The Clearinghouse has grown steadily since its launch in } \\
2010 \text {, from a few dozen documents to over } 3,830 \text { as of September } 2013 \text {. The rapid } \\
\text { expansion of the database will continue as the Centre adds new documents every } \\
\text { month, including books, videos, national/regional strategy documents, project } \\
\text { reports, studies and scholarly articles, among others. The expansion of the database } \\
\text { is complemented by broad use of the facility by target audiences from across the } \\
\text { region and internationally- namely the press, the public, project teams, consultants, } \\
\text { experts, researchers, students, focal points, governments and partner organizations. } \\
\text { This wide usage is evidenced by average monthly downloads of } 8,500 \text { documents } \\
\text { between December } 2012 \text { and February } 2013 \text { " (CCCCC, 2015j, online). }\end{array}$ & \\
\hline & $\begin{array}{l}\text { 2. The organisation makes climate } \\
\text { change adaptation-relevant } \\
\text { research publicly available. }\end{array}$ & $\begin{array}{l}\text { The Centre's clearinghouse mechanism is publicly available at: } \\
\text { http://clearinghouse.caribbeanclimate.bz/. Visitors to the site can access information } \\
\text { by topic or country, and about regional climate models and strategies, programs, } \\
\text { policies and projects. }\end{array}$ & 甲 \\
\hline $\begin{array}{l}\text { 3. Collaboration and } \\
\text { advocacy }\end{array}$ & $\begin{array}{l}\text { 3. There is evidence that the } \\
\text { organisation collaborates with } \\
\text { multiple stakeholders to } \\
\text { undertake climate change } \\
\text { adaptation-related activities. }\end{array}$ & $\begin{array}{l}\text { The Centre's regional and international partners, including the IPCC, have endorsed } \\
\text { CCORAL (CNS, 2015). "CCORAL, which was launched by the Centre in July } 2013 \text {, } \\
\text { is an online support tool developed to strengthen climate resilient decision-making } \\
\text { processes across various sectors in the Caribbean by embedding a risk ethic" (CNS, } \\
2015 \text {, online). } \\
\text { "The Centre has been working with the Caribbean Development Bank, its } \\
\text { longstanding partner and a permanent member of the } 11 \text { member Board of Governors, } \\
\text { and other development partners to mobilise private sector support for the tool" (CNS, } \\
2015 \text {, online). } \\
\text { "The Centre's most recent programme is a } € 12.8 \text { million initiative to address } \\
\text { ecosystems-based adaptation under an agreement with the German Development } \\
\text { Bank (KfW). The KfW supported engagement seeks to protect the region's extensive } \\
\text { coastal resources through a combination of ecosystems-based adaptation and } \\
\text { environmental engineering approaches that will also embed livelihood considerations } \\
\text { as a core element of the programme" (CNS, 2015, online). }\end{array}$ & $\nabla$ \\
\hline
\end{tabular}




\begin{tabular}{|c|c|c|c|}
\hline \multirow[t]{3}{*}{ SUB-COMPONENT } & INDICATOR & EVIDENCE & RATING \\
\hline & & $\begin{array}{l}\text { "The Centre is currently housed in rented facilities provided by the Government of } \\
\text { Belize. The Government of Belize has allocated } 10 \text { acres of land to the Centre, on } \\
\text { which a custom-designed, 'green' facility will be constructed" (CNS, 2015, online). }\end{array}$ & \\
\hline & $\begin{array}{l}\text { 4. The organisation advocates for } \\
\text { political, financial and/or other } \\
\text { climate change support for its } \\
\text { Member Countries in various } \\
\text { fora at different scales. }\end{array}$ & $\begin{array}{l}\text { "Executive Director Dr. Kenrick Leslie says the Centre, under a directive from } \\
\text { CARICOM Heads, has been "working with national governments to put together } \\
\text { programmes that would help them develop bankable projects that can be funded } \\
\text { under the various mechanisms under the United Nations Framework Convention on } \\
\text { Climate Change. The Centre is putting maximum effort to ensure CARICOM } \\
\text { Member States get their fair share of the Green Climate Fund (GCF), Adaptation } \\
\text { Fund (AF) and other funds to help them in their adaptation efforts. That is our primary } \\
\text { thrust - to meet the mandate given to us by the regional Heads" (CNS, 2015, online). } \\
\text { "The Ministry of Sustainable Development, Energy, Science and Technology in } \\
\text { collaboration with the Caribbean Community Climate Change Centre (CCCC) and } \\
\text { the High Level Support Mechanism (HLSM) will be hosting a regional meeting for } \\
\text { climate change negotiators and ministers with responsibility for climate change from } \\
\text { Wednesday 16th September, } 2015 \text { to Friday 18th September, } 2015 \text { in Saint Lucia. } \\
\text { The meeting which was requested by Prime Minister, Hon. Dr. Kenny D. Anthony at } \\
\text { the last meeting of CARICOM Heads in Barbados, is expected to achieve the } \\
\text { following: } \\
\text { - Establish coherence among negotiators on the critical issues in the } \\
\text { negotiations toward a new climate change agreement in Paris in December } \\
\text { 2015; } \\
\text { Apprise of the areas of convergence and divergence in the ongoing climate } \\
\text { change negotiations; and } \\
\text { - Prepare Ministers for a meeting of the Alliance of Small Island States } \\
\text { (AOSIS) in New York on Thursday 24th September, } 2015 \text { which will take } \\
\text { place on the eve of the Post } 2015 \text { Development Agenda Summit" } \\
\text { (Government of St. Lucia, 2015, online). } \\
\text { "Dr. Neville Trotz, Science Adviser and Deputy Director at the Belmopan, Belize- } \\
\text { based CARICOM Climate Change Centre delivered a well-received statement on } \\
\text { behalf of the region at the recently concluded COP18 talks in Doha, Qatar. Dr. Trotz } \\
\text { declared that the region continues to address Climate Change in spite of global } \\
\text { challenges. He added that the region's home grown approach is deliberate and a } \\
\text { matter of survival. He cited the CARICOM endorsed Regional Strategic Framework } \\
\text { for Achieving Development Resilient to Climate Change and the accompanying }\end{array}$ & $\nabla$ \\
\hline
\end{tabular}




\begin{tabular}{|c|c|c|c|}
\hline SUB-COMPONENT & INDICATOR & $\begin{array}{c}\text { EVIDENCE } \\
\end{array}$ & RATING \\
\hline & & $\begin{array}{l}\text { Implementation Plan as key policy and operational plans that are guiding the } \\
\text { Caribbean response" (CCCCC, 2015e, online). } \\
\text { "The Caribbean Community Climate Change Centre hosted together with the South } \\
\text { Pacific a [sic] Exhibit at the 17th Conference of the Parties (COP 17) In Durban South } \\
\text { Africa. A video was presented on the DVD "Caricom [sic] Countries - Meeting the } \\
\text { Challenge of Climate Change", produced by the Centre and disseminated at COP } 17 \\
\text { held in Durban. It provides a concise, yet fascinating account of just how much the } \\
\text { various components of the region's economies stand to lose from the threat of climate } \\
\text { change. In addition it distinctly highlights the achievements and activities of the } \\
\text { Centre via its numerous past and contemporary regional projects, as explained in } \\
\text { interviews with senior staff members. More specifically, it outlines the impending } \\
\text { threats to tourism, agriculture, public health and other sectors while also explaining, } \\
\text { through interviews with senior staff, the extensive achievements of past and current } \\
\text { regional projects and initiatives. The video ends on a cautionary note, pointing to the } \\
\text { urgency of policy to commit to a reduction in emissions in order to stem the tide of } \\
\text { climate related impacts" (CCCCC, 2015d, online). }\end{array}$ & \\
\hline $\begin{array}{ll}\text { 6. } & \text { Education and } \\
\text { training }\end{array}$ & $\begin{array}{l}\text { 3. The organisation undertakes } \\
\text { climate change adaptation } \\
\text { stakeholder and/or public } \\
\text { awareness activities. }\end{array}$ & $\begin{array}{l}1.5 \text { to stay alive campaign } \\
\text { "Cognizant of the threat Climate Change poses to the region's survival and continued } \\
\text { development, the Caribbean Community Climate Change Centre launched the } 1.5^{\circ} t o \\
\text { Stay Alive campaign ahead of COP15 in December } 2009 \text {. The two tiered campaign } \\
\text { sought to sensitize [sic] citizens across the Caribbean Community about the impact } \\
\text { of Climate Change on livelihoods in the region, and make a convincing case at the } \\
\text { global level for the reduction of GHG emissions to a level not exceeding } 350 \mathrm{ppm} \\
\text { (parts per million) as an effective means of stabilising global warming. Owing to the } \\
\text { region's vulnerability to climate change and variability and its particularly youthful } \\
\text { population, the Centre seeks to engage this significant demographic to shape a robust } \\
\text { and appropriate range of responses to ensure climate resilience and safeguard } \\
\text { livelihoods. In light of this, the Centre supported a Youth Forum on climate change } \\
\text { aimed at high school students in Belize in } 2010 \text {. Through this initiative, students were } \\
\text { engaged about how their individual actions contribute to the broader challenge of } \\
\text { climate and the ways in which they can both adapt and mitigate such amidst a } \\
\text { changing and variable climate. The project also engaged teachers to examine ways in } \\
\text { which climate change education may be mainstreamed into the education sector, and } \\
\text { resulted in the creation of a climate change toolkit" (CCCCC, 2015h, online). }\end{array}$ & $\square$ \\
\hline
\end{tabular}




\begin{tabular}{|c|c|c|c|}
\hline SUB-COMPONENT & INDICATOR & $\begin{array}{l}\text { EVIDENCE } \\
\end{array}$ & RATING \\
\hline & & 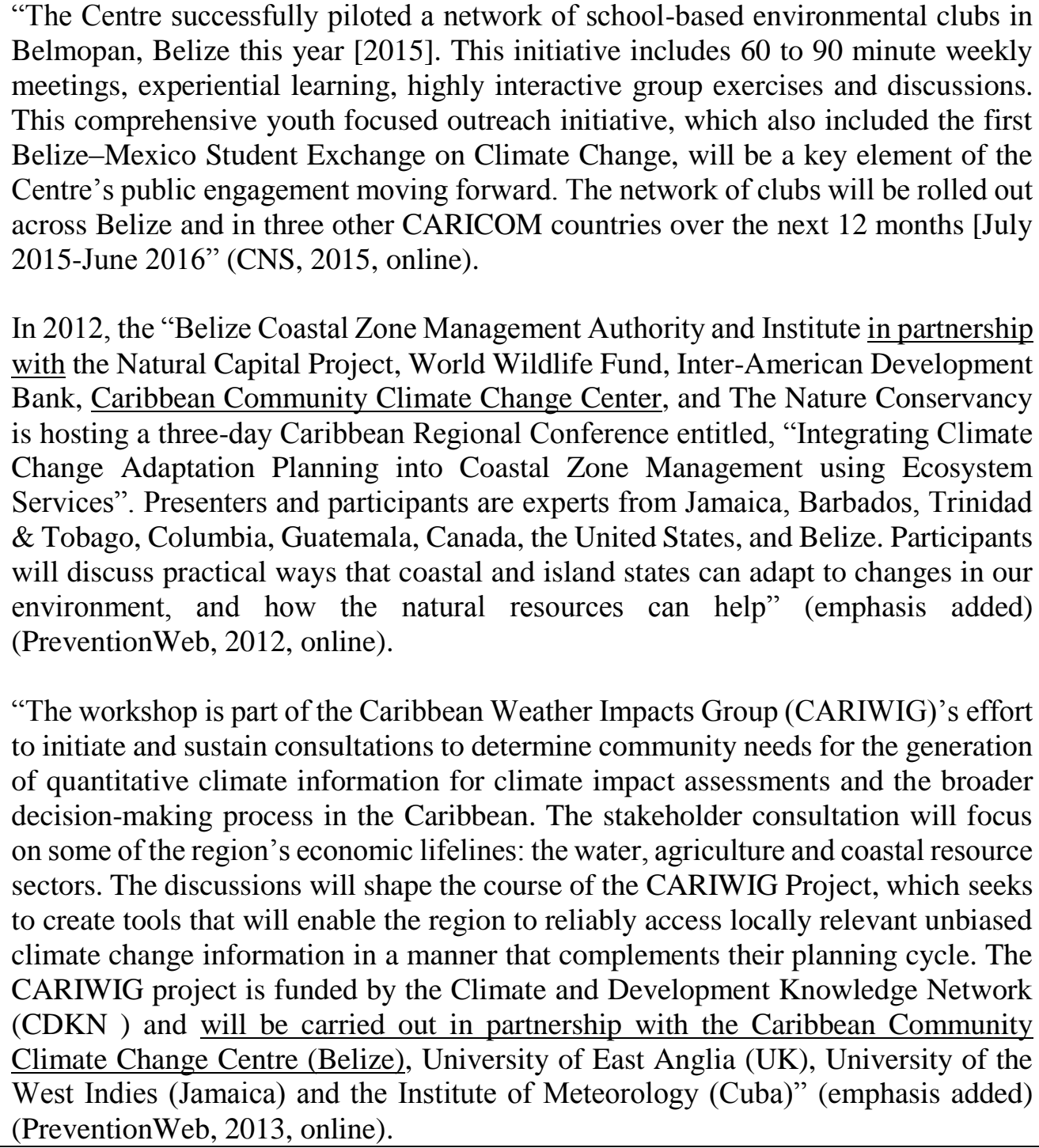 & \\
\hline & $\begin{array}{l}\text { 4. The organisation develops and/or } \\
\text { implements training programs for } \\
\text { stakeholders in issues related to } \\
\text { climate change adaptation. }\end{array}$ & $\begin{array}{l}\text { The Centre has "been recognised by the United Nations Institute for Training and } \\
\text { Research (UNITAR) as a Centre of Excellence, one of an elite few" (CARICOM } \\
\text { Secretariat, 2011b, online). }\end{array}$ & $\square$ \\
\hline
\end{tabular}




\begin{tabular}{|c|c|c|c|}
\hline SUB-COMPONENT & INDICATOR & EVIDENCE & RATING \\
\hline & & $\begin{array}{l}\text { "The Caribbean Community Climate Change Centre (CCCCC) recently organized a } \\
\text { training course entitled "The Use of Sector-Specific Biophysical Models in Impact } \\
\text { Assessment in the Caribbean". This course was implemented under the European- } \\
\text { Union (EU) funded Regional Global Climate Change Alliance (GCCA) Project in } \\
\text { partnership with the Government of Jamaica. The main objective of the training } \\
\text { course was to provide technicians and practitioners of the Caribbean region with an } \\
\text { opportunity to apply existing climate models as tools for sector-specific decision- } \\
\text { making in the context of climate change adaptation. The training course covered two } \\
\text { modules: (1) "The Science of Climate Change" and (2) "Vulnerability and Adaptation } \\
\text { to Climate Change". The course curriculum was based on the training manual and } \\
\text { workbook developed by Cuba's Institute of Meteorology (INSMET) and the CCCCC, } \\
\text { and was delivered by a team of trainers from INSMET. The training course was held } \\
\text { at the University of the West Indies (UWI) Mona Campus in Jamaica from January } 6 \\
-17 \text {, 2014. The target audience for the course included climate change experts, } \\
\text { technicians and practitioners from public and private sectors as well as non- } \\
\text { governmental organizations. Key organizations and groups represented at the course } \\
\text { included Antigua \& Barbuda's Ministry of Agriculture; the Bahamas Meteorological } \\
\text { Service; the National Climate Change Office of the Dominican Republic; Haiti's } \\
\text { Ministry of Environment, and post-graduate students of UWI's St. Augustine } \\
\text { Campus. Belize was represented at the training by personnel from the National } \\
\text { Emergency Management Organization (NEMO) as well as CZMAI's Data Analyst, } \\
\text { Ms. Maritza Canto. According to Ms. Canto this training provided many } \\
\text { methodologies for the application of basic climate based models that can be used to } \\
\text { enhance climate adaptation planning for the various productive sectors in Belize" } \\
\text { (Government of Belize, 2014, online). }\end{array}$ & \\
\hline $\begin{array}{l}\text { 7. Specialised } \\
\text { advisory services }\end{array}$ & $\begin{array}{l}\text { 2. The organisation provides } \\
\text { specialised climate change } \\
\text { adaptation-related advice to } \\
\text { Member Countries and/or other } \\
\text { stakeholders. }\end{array}$ & $\begin{array}{l}\text { The Centre "provides climate change-related policy advice and guidelines to the } \\
\text { Caribbean Community (CARICOM) Member States through the CARICOM } \\
\text { Secretariat" (CCCCC, 2015c, online). } \\
\text { "Delivering Transformational Change" was "prepared by the Caribbean Community } \\
\text { Climate Change Centre in response to a request from the CARICOM Heads of } \\
\text { Government to produce an Implementation Plan to guide the delivery of the } \\
\text { "Regional Framework to Achieving Development Resilient to Climate Change"" } \\
\text { (CCCCC, 2012). }\end{array}$ & $\square$ \\
\hline & & $\begin{array}{c}\text { 4. Outcome Effectiveness } \\
-\end{array}$ & \\
\hline
\end{tabular}

Appendix 3: Application of FAROCCCA to CCCCC (cont'd) 
Appendix 4: Application of FAROCCCA to SPC

\begin{tabular}{|c|l|}
\hline \multicolumn{2}{|c|}{ RATING SYSTEM } \\
\hline $\boldsymbol{\otimes}$ & No \\
\hline$\diamond$ & To some extent \\
\hline$\square$ & Yes \\
\hline$(\mathrm{NE})$ & No evidence \\
\hline & Perceptual indicator or indicator not rated in this paper \\
\hline
\end{tabular}

\begin{tabular}{|c|c|c|c|}
\hline \multirow[t]{2}{*}{ SUB-COMPONENT } & \multirow[t]{2}{*}{ INDICATOR } & \multirow[t]{2}{*}{ EVIDENCE } & \multirow[t]{2}{*}{ RATING } \\
\hline & & & \\
\hline 1. Goals & $\begin{array}{l}\text { 1. Climate change adaptation was an } \\
\text { initial goal of the organisation. }\end{array}$ & $\begin{array}{l}\text { SPC was established by the Canberra Agreement, in 1947. The goal of the } \\
\text { agreement does not include environmental considerations, but rather, is to } \\
\text { promote the "economic and social welfare and advancement of the peoples of } \\
\text { the ... South Pacific region" (SPC, 1947, p. 1). } \\
\text { The word 'environment' appears twice in the text, as recommendations for the } \\
\text { newly established commission to undertake studies on the "relationship between } \\
\text { plants and their environment including soils and climate" (SPC, 1947, p. 11), } \\
\text { and on the "human body's response to changes of climate and environment" } \\
\text { (SPC, 1947, p. 12). } \\
\text { The Tahiti Nui Declaration is not a legal document, but presents a regularly } \\
\text { updated description of SPC's major policies and implementation mechanisms. } \\
\text { The declaration includes adaptation to climate change, and disaster risk } \\
\text { reduction as cross-cutting themes (SPC, 2011e, article 19). } \\
\text { *Colonial organisation; established by AUS, NZ, USA, UK, France, Holland etc } \\
\text { before PICTs were self-governing* }\end{array}$ & 冈 \\
\hline & $\begin{array}{l}\text { 2. Climate change adaptation is a } \\
\text { current goal of the organisation. }\end{array}$ & $\begin{array}{l}\text { The SPC 2007-2012 corporate plan includes climate change (both adaptation } \\
\text { and mitigation) as a cross-cutting programme commitment (SPC, 2007, p. 11). } \\
\text { SPC's 2013-2015 Corporate Plan mentions adaptation to climate change under } \\
\text { a number of sectoral headings, including fisheries (p. 21), Water and Sanitation } \\
\text { (p. 15), and as an example of SPC's multi-sectoral capabilities (p. 9 \& 11) (SPC, } \\
\text { 2013). }\end{array}$ & $\square$ \\
\hline
\end{tabular}




\begin{tabular}{|c|c|c|c|}
\hline \multirow[t]{4}{*}{ SUB-COMPONENT } & INDICATOR & $\begin{array}{l}\text { EVIDENCE } \\
\end{array}$ & RATING \\
\hline & & $\begin{array}{l}\text { SPC also published an internal engagement strategy for climate change in } 2011 \\
\text { (SPC, 2011d), which includes the word 'adaptation' } 56 \text { times, and the word } \\
\text { 'mitigation' } 15 \text { times. }\end{array}$ & \\
\hline & $\begin{array}{l}\text { 3. The current strategic plan contains } \\
\text { specific climate change adaptation } \\
\text { objectives. }\end{array}$ & $\begin{array}{l}\text { The SPC Corporate Plan (2013-2015) strategic goals mentions adaptation under } \\
\text { water and sanitation: "Number of PICTs water sectors with increased } \\
\text { engagement and contribution to national efforts in disaster risk reduction, } \\
\text { response, and climate change adaptation" (SPC, 2013, p. 15). The baseline for } \\
\text { this was to be reported to the Committee of Representatives of Governments and } \\
\text { Administrations in 2013, with } 22 \text { PICTS to have achieved the goal by } 2015 \text {. } \\
\text { There are also three goals related to climate change and DRR in the corporate } \\
\text { plan. }\end{array}$ & $\diamond$ \\
\hline & $\begin{array}{l}\text { 4. There is no other regional } \\
\text { organisation with similar climate } \\
\text { change adaptation goals. }\end{array}$ & $\begin{array}{l}\text { "SPC has taken a lead role in creating a joint regional platform on climate } \\
\text { change and disaster risk management. It has also led the development of the } \\
\text { Strategy for Climate and Disaster Resilient Development in the Pacific } \\
\text { (SRDP)" (SPC, 2014g, p. 35). } \\
\text { SPREP "is the convener and coordinator of the PCCR [Pacific Climate Change } \\
\text { Roundtable] in collaborations with CROP and key development partners" } \\
\text { (SPREP, 2014g). } \\
\text { "SPC acknowledges the lead role of SPREP in climate change advocacy, } \\
\text { regional and international coordination, regional climate change policy and } \\
\text { frameworks, and its own work in climate change mitigation and adaptation. We } \\
\text { also acknowledge the role of PIFS in providing political leadership and in } \\
\text { coordinating climate change financing initiatives for the region, the critical role } \\
\text { of USP in climate change education and research, and the roles of FFA and PPA } \\
\text { in climate change adaptation and mitigation. For its part, SPC covers the } \\
\text { broadest range of sectors that are impacted by climate change in the region. It } \\
\text { has in-house capacity to assist members to develop and implement climate } \\
\text { change adaptation responses in all these sectors it works in at the national level. } \\
\text { SPC also undertakes scientific research on the impacts of climate change on } \\
\text { natural ecosystems, and has strong capacity to analyse the socio-cultural and } \\
\text { economic impacts of climate change on the region. SPC is directly involved in } \\
\text { implementing climate change adaptation work on the ground at national level in } \\
\text { all PICTs across all the sectors it works in, as well as in undertaking advanced } \\
\text { scientific research in agriculture, fisheries and forestry" (SPC, 2011d, p13). }\end{array}$ & $\boldsymbol{\nabla}$ \\
\hline
\end{tabular}




\begin{tabular}{|c|c|c|c|}
\hline SUB-COMPONENT & INDICATOR & EVIDENCE & RATING \\
\hline \multirow[t]{4}{*}{$\begin{array}{l}\text { 2. Governance and } \\
\text { leadership }\end{array}$} & $\begin{array}{l}\text { 1. The Board provides visionary } \\
\text { leadership and strategic direction. }\end{array}$ & & \\
\hline & $\begin{array}{l}\text { 2. The organisation evaluates } \\
\text { organisational performance at least } \\
\text { annually. }\end{array}$ & $\begin{array}{l}\text { SPC's 2013-15 corporate plan seeks to increase the focus on results, targeting } \\
\text { an increase from one or two to seven "divisions with results-focused strategic } \\
\text { plans and annual reports using clear results frameworks" (SPC, 2013, p. 17). }\end{array}$ & $\diamond$ \\
\hline & $\begin{array}{l}\text { 3. Executive management (can also } \\
\text { include members of the } \\
\text { Board/Governing Body) decision- } \\
\text { making is done by consensus or } \\
\text { majority vote. }\end{array}$ & $\begin{array}{l}\text { "SPC's governing body The Conference of the Pacific Community, which is } \\
\text { held every two years, is the governing body of SPC with each member entitled } \\
\text { to one vote on decisions. However, debates are usually resolved in the Pacific } \\
\text { way by consensus. The Committee of Representatives of Governments and } \\
\text { Administrations (CRGA) meets annually, and in the years that the conference } \\
\text { does not meet, is empowered to make decisions on the governance of SPC" } \\
\text { (emphasis added) (SPC, 2011c). The Conference is attended by heads and } \\
\text { deputy heads of state, ministers, ambassadors, high commissioners, and senior } \\
\text { officials from members states (SPC, 2010b, p. 64). }\end{array}$ & 口 \\
\hline & $\begin{array}{l}\text { 4. Executive management staff (can } \\
\text { also include members of the } \\
\text { Board/Governing Body) are } \\
\text { qualified and/or equipped to achieve } \\
\text { the goals of the organisation. }\end{array}$ & $\begin{array}{l}\text { SPC's Director-General serves a two year term, and while the details of the } \\
\text { evaluation are not published, SPC's } 2009 \text { annual report notes the unanimous } \\
\text { agreement to reappoint the DG under the heading "Evaluation of the Director- } \\
\text { General's Performance" (SPC, 2010b, p. 70). } \\
\text { "Dr Colin Tukuitonga took up the post of Director-General of SPC } 23 \text { January } \\
\text { 2014. He will be based at SPC's headquarters in Noumea, New Caledonia. Dr } \\
\text { Tukuitonga, who is from Niue, has a first-hand appreciation of the development } \\
\text { challenges facing the Pacific and more than } 27 \text { years' experience working in a } \\
\text { variety of roles, including as a clinician, academic, programme manager and } \\
\text { consultant adviser. Recent roles as Director of SPC's Public Health Division } \\
\text { since December } 2012 \text { and earlier as a member of the team that carried out an } \\
\text { independent external review of SPC in the first half of } 2012 \text { have given him a } \\
\text { sound understanding of SPC's operations. He has worked in Niue, Fiji, New } \\
\text { Zealand and Switzerland in senior roles including Chief Executive Officer of } \\
\text { the Ministry of Pacific Island Affairs of the New Zealand Government; } \\
\text { Associate Professor of Public Health and Head of Pacific and International } \\
\text { Health at the University of Auckland; Director of Public Health in the New } \\
\text { Zealand Ministry of Health; and Head of Surveillance and Prevention of Chronic } \\
\text { Diseases with the World Health Organization in Geneva" (SPC, 2014e, online). }\end{array}$ & $\nabla$ \\
\hline & $\begin{array}{l}\text { 5. Executive management staff } \\
\text { disclose potential conflicts of } \\
\text { interest. }\end{array}$ & & \\
\hline
\end{tabular}




\begin{tabular}{|c|c|c|c|}
\hline SUB-COMPONENT & INDICATOR & EVIDENCE & RATING \\
\hline & & $\begin{array}{l}\text { three years, and for staff recruited internationally, their positions must be } \\
\text { advertised after six years (this is known as the six-year rule)" (SPC, 2014d, p. } \\
\text { 1). }\end{array}$ & \\
\hline & $\begin{array}{l}\text { 7. Leaders create a dynamic } \\
\text { organisational culture, making the } \\
\text { organisation a desirable place to } \\
\text { work. }\end{array}$ & & \\
\hline \multirow[t]{2}{*}{ 3. Resources } & $\begin{array}{l}\text { 1. There are staff members exclusively } \\
\text { dedicated to climate change } \\
\text { adaptation. }\end{array}$ & $\begin{array}{l}\text { "The climate change support team will work closely with SPC divisional } \\
\text { managers and programme staff to help identify areas where existing } \\
\text { programmes can be expanded to incorporate activities that will meet the climate } \\
\text { change-related needs of members" (SPC, 2011d, p. 10). } \\
\text { SPC has eleven staff in their "climate change unit (USAID Project and EU- } \\
\text { GCCA Project)" (http://gsd.spc.int/staff), however none of these positions are } \\
\text { listed as exclusively focussed on adaptation. }\end{array}$ & $\diamond$ \\
\hline & $\begin{array}{l}\text { 2. Staff are qualified and have } \\
\text { experience in climate change } \\
\text { adaptation. }\end{array}$ & $\begin{array}{l}\text { SPC's climate change strategy includes having "[d]edicated internal climate } \\
\text { change policy and advisory support services in place to meet organisational } \\
\text { needs" (SPC, 2011d, p. 11). } \\
\text { In August 2015, Sylvie Goyet was "appointed to the position of SPC Director, } \\
\text { Environmental Sustainability and Climate Change based in Noumea, New } \\
\text { Caledonia. Sylvie comes with 20-years of experience in environmental } \\
\text { programme development and implementation, with special expertise in coastal } \\
\text { and marine issues, and a general background in management and strategic } \\
\text { planning. Sylvie's main duties will be coordinating the broad portfolio of } \\
\text { projects that SPC is carrying out in the area of climate change and incorporating } \\
\text { the concept of environmental sustainability into all of SPC's work. The position } \\
\text { is funded by the Government of France" (SPC - Geoscience Division, 2015). } \\
\text { "Prof. Michael Petterson has taken up his appointment as Director of the } \\
\text { Secretariat of the Pacific Community (SPC) Applied Geoscience and } \\
\text { Technology Division (SOPAC) succeeding Dr Russell Howorth, whose tenure } \\
\text { with the organization officially ended on } 31 \text { st January 2013. Before taking up } \\
\text { this position with SPC, Prof. Petterson, who is from the United Kingdom, held } \\
\text { a Professorship of Applied and Environmental Geosciences at the University of } \\
\text { Leicester, from 2009, before which he was Director of Science, Skills and } \\
\text { Facilities at the British Geological Survey for five years. }\end{array}$ & $\diamond$ \\
\hline
\end{tabular}




\begin{tabular}{|c|c|c|c|}
\hline SUB-COMPONENT & INDICATOR & $\begin{array}{ll}\text { EVIDENCE } \\
\end{array}$ & RATING \\
\hline & & $\begin{array}{l}\text { Holding a PhD in geology (1984) and a post graduate certificate in education } \\
\text { (1985), Prof. Petterson is a chartered geologist, a chartered engineer, Fellow of } \\
\text { the Geological Society of London, Member of the Institute of Materials, Mining } \\
\text { and Metallurgy, life member of the Association of Geoscientists for } \\
\text { International Development, Member of the Society of Economic Geologists, and } \\
\text { he is a member of the STAR network. } \\
\text { As well as his career as a geologist, Prof. Petterson has published extensively, } \\
\text { and brings a strong understanding of the SPC SOPAC Division to his new } \\
\text { appointment, through his previous work in the Pacific region in the Solomon } \\
\text { Islands and Papua New Guinea. His work has also taken him to South and South- } \\
\text { east Asia, the Caribbean and South America" (SPC - Geoscience Division, } \\
\text { 2013b). }\end{array}$ & \\
\hline & $\begin{array}{l}\text { 3. Staff are qualified and have } \\
\text { experience in project/program } \\
\text { management. }\end{array}$ & $\begin{array}{l}\text { "SPC has a world-class contingent of fisheries development and management } \\
\text { experts and scientists who can work in partnership with PICTs to address the } \\
\text { impact of climate change on Pacific fisheries" (SPC, 2011d, p. 19). } \\
\text { "Mr Amos is a citizen of Vanuatu. He has a master's degree in Biological } \\
\text { Science from the University of Auckland and a Bachelor's Degree in Zoology } \\
\text { from Otago University, New Zealand. Mr Amos is fluent in English, Bislama, } \\
\text { Melanesian Pidgin and has a working knowledge of French. } \\
\text { Mr Amos is currently the Director of the Department of Fisheries in Vanuatu, a } \\
\text { position he has held over a period of } 12 \text { years from September } 1997 \text { to December } \\
2006 \text { and again from September } 2010 \text { till now. From January } 2007 \text { to March } \\
2010 \text { Mr Amos was Director of Fisheries Management at the Forum Fisheries } \\
\text { Agency in Honiara. } \\
\text { Mr Amos has worked both regionally and nationally and has a strong grasp of } \\
\text { the economic, political and cultural dynamics of the region as well as the } \\
\text { fisheries' regional and country policies, infrastructure and programmes. He has } \\
\text { a strong background in the development and management of fisheries policies } \\
\text { and their implementation at both national and regional levels. He has a very } \\
\text { strong grasp of the key issues in fisheries in particular as seen from the } \\
\text { perspectives of SPC's island members. } \\
\text { Mr Amos' previous role as a member of FFA's management team will augur } \\
\text { well in further strengthening the relationship between SPC and FFA in the }\end{array}$ & $\square$ \\
\hline
\end{tabular}




\begin{tabular}{|c|c|c|c|}
\hline \multirow[t]{2}{*}{ SUB-COMPONENT } & INDICATOR & EVIDENCE & RATING \\
\hline & & $\begin{array}{l}\text { fisheries sector which in turn will further strengthen the collective effort of both } \\
\text { organisations to serve our mutual membership better" (Emphasis added) (SPC, } \\
\text { 2014a). }\end{array}$ & \\
\hline & $\begin{array}{l}\text { 4. Staff participate in ongoing training } \\
\text { programs. }\end{array}$ & $\begin{array}{l}\text { "Training and technical skills development will be provided as appropriate to } \\
\text { ensure that staff have the most up-to-date information on how climate change } \\
\text { will impact on their specific areas of focus" (SPC, 2011d, p. 10). } \\
\text { "The Teamwork and Innovation category was won by ICT Suva for introducing } \\
\text { new initiatives alongside ongoing staff training and technical support" (SPTO, } \\
\text { 2015). } \\
\text { "Two technical staff of SPC (Cenon and Vinesh) are currently in Vava'u, Tonga } \\
\text { to undertake Agroforestry training. } 32 \text { participants with 50\% women are in } \\
\text { attendence. Topics covered in this training: Climate Change, Food Security, best } \\
\text { agricultural practices, nursery development and management, Beekeeping, } \\
\text { Aquaculture, Post-harvest and composting" (SPC Facebook post). } \\
\text { "Monday } 16 \text { September 2013, Secretariat of the Pacific Community (SPC), } \\
\text { Suva, Fiji: Fifty-nine staff members of the Secretariat of the Pacific (SPC) staff } \\
\text { have completed disaster risk management (DRM) and climate change training } \\
\text { in recent months" (SPC - Geoscience Division, 2013a). } \\
\text { It is worth noting that DRM and climate change adaptation in the Pacific are } \\
\text { becoming integrated into single policies (JNAPs). For example, in Tonga, } \\
\text { "There were unanimous endorsements [from Cabinet Ministers, CEOs of line } \\
\text { ministries, civil society representatives and NGOs] for a joint plan due to the } \\
\text { close linkages of climate change impacts and disaster risk management but also } \\
\text { to avoid duplication of efforts and maximize the use of the limited resources in } \\
\text { Tonga" (The Kingdom of Tonga, 2010, p. 28). }\end{array}$ & $\nabla$ \\
\hline & $\begin{array}{l}\text { 5. Staff performance is appraised } \\
\text { (formally or informally) at least } \\
\text { annually. }\end{array}$ & $\begin{array}{l}\text { "A new Human Resources Adviser (Remuneration and Human Resources } \\
\text { Information System) was recruited in July. His initial priorities are reviewing } \\
\text { the annual performance appraisal process, undertaking a critical review of the } \\
\text { remuneration system for internationally recruited staff in liaison with the other } \\
\text { agencies making up CROP (Council of Regional Organisations in the Pacific), } \\
\text { and consolidating the HR Online information system introduced in 2014" } \\
\text { (emphasis added) (SPC, 2014d, p. 2). }\end{array}$ & $\nabla$ \\
\hline
\end{tabular}




\begin{tabular}{|c|c|c|c|}
\hline SUB-COMPONENT & INDICATOR & $\begin{array}{l}\text { EVIDENCE } \\
\end{array}$ & RATING \\
\hline & 6. The organisation has untied funding. & $\begin{array}{l}\text { In the SPC } 2009 \text { annual accounts, over } 45 \% \text { of their funding (USD } \$ 40,565,916) \\
\text { was from member contributions, including from Australia, France, New Zealand } \\
\text { and the USA (SPC, 2010a, p. 44). } \\
\text { SPC's } 2013-15 \text { corporate plan notes that there is a risk of SPC not meeting its } \\
\text { core funding target, which could "have a significant impact on the ability of SPC } \\
\text { to meet the organisational development targets of this [2013-15] plan" (SPC, } \\
2013 \text {, p. 12). }\end{array}$ & 口 \\
\hline & $\begin{array}{l}\text { 7. The organisation has funds } \\
\text { exclusively dedicated to climate } \\
\text { change adaptation. }\end{array}$ & $\begin{array}{l}\text { SPC accounts show funds spent on coastal climate change projects, climate } \\
\text { change mainstreaming, "Climate impact on C.F. / O.F." (SPC, 2010a), climate } \\
\text { change science and adaptation planning, and on assessing vulnerability and } \\
\text { adaptation (SPC, 2014f). }\end{array}$ & $\square$ \\
\hline & $\begin{array}{l}\text { 8. External funding to the organisation } \\
\text { has increased over the past } 5 \text { years. }\end{array}$ & $\begin{array}{l}\text { "At present, one CFP unit equals } 1 \text { USD. A 'CFP unit' is simply } 100 \text { CFP } \\
\text { (French Pacific Franc, the local currency in French Polynesia, New Caledonia, } \\
\text { and Wallis and Futuna and the operating currency of the Secretariat)" (SPC, } \\
\text { 2004, p. 10). } \\
\text { Non-member contributions in: } \\
\text { 2008: CFP Units 9,624,693 } \\
\text { 2009: CFP Units 4,417,144 (SPC, 2010a, p. 7). } \\
\text { 2012: CFP Units 27,062,691 } \\
\text { 2013: CFP Units 51,012,811 (SPC, 2014f, p. 13). }\end{array}$ & $\square$ \\
\hline & $\begin{array}{l}\text { 9. The organisation has multiple } \\
\text { funding sources. }\end{array}$ & $\begin{array}{l}\text { In } 2013 \text { SPC received contributions from } 26 \text { members states totalling around } \\
\text { USD\$58.5Million, and contributions from } 34 \text { non-member organisations } \\
\text { totalling around USD\$59Million (SPC, 2014f, pp. 47-48). }\end{array}$ & $\square$ \\
\hline & $\begin{array}{l}\text { 10. The organisation has financial } \\
\text { reserves. }\end{array}$ & $\begin{array}{l}\text { "The secretariat's reserves as per the approved } 2014 \text { accounts are currently } 6.5 \\
\text { million CFP units. Taking into account the } 605,000 \text { units used to balance the } \\
2015 \text { revised budget, as per CRGA 43's authorisation, and the secretariat's } \\
\text { request to use } 600,000 \text { CFP units to fund priorities and initiatives under the new } \\
\text { Strategic Plan, the level of reserves in } 2016 \text { would be } 5.3 \text { million CFP units in } \\
\text { total. This is well above the } 4.1 \text { million unit figure presented at CRGA } 44 \text { and } \\
\text { the } 2015 \text { CRGA target of five million CFP units. This is due both to the } \\
\text { contribution made by the secretariat under the } 2016 \text { budget and to surplus funds } \\
\text { in reserves identified after a thorough review. Reserves would thus have been } \\
\text { strengthened by } 1.2 \text { million CFP units in total over the course of FY } 2015 \text { and } \\
\text { into FY 2016" (SPC, 2015a, p. 10). }\end{array}$ & $\square$ \\
\hline
\end{tabular}




\begin{tabular}{|c|c|c|c|}
\hline SUB-COMPONENT & INDICATOR & $\begin{array}{l}\text { EVIDENCE } \\
\end{array}$ & RATING \\
\hline & & $\begin{array}{l}\text { SPC's } 2013 \text { Annual Report notes an operating surplus of CFP Units 1,959,955 } \\
\text { (SPC, 2014f, p. 18). } \\
\text { Also, as at December } 312013 \text { SPC had a little over 102 Million CFP units in } \\
\text { assets, including } 70 \text { Million in cash (SPC, 2014f, p. 11). } \\
\text { SPC has a core budget separate from its project funds, and the secretariat is } \\
\text { proactively trying to build financial reserves (SPC, 2014f, p. 3). } \\
\text { SPC seeks to have a balanced budget each year: "The revised } 2014 \text { budget is a } \\
\text { balanced budget, totalling } 110.401 \text { million CFP units (core funding } 30.841 \\
\text { million CFP units, project funding } 79.560 \text { million CFP units) in income and } \\
\text { expenditure. Overall, the } 2014 \text { revised budget reflects an increase of } 15.044 \\
\text { million or } 15.8 \% \text { compared to the original budget of } 95.3574 \text { million CFP units. } \\
\text { 4. The Secretariat proposes a balanced } 2015 \text { budget of } 110.951 \text { million CFP } \\
\text { units, comprising the core budget of } 32.97 \text { million CFP units and project fundi } \\
\text { ng of } 77.981 \text { million CFP units" (SPC, } 2014 b, \text { p. 1). }\end{array}$ & \\
\hline & $\begin{array}{l}\text { 11. The organisation has sufficient } \\
\text { technological resources (e.g. } \\
\text { intellectual property rights, patents, } \\
\text { copyright, software licences etc.) to } \\
\text { carry out its climate change } \\
\text { adaptation mandate. }\end{array}$ & & \\
\hline \multirow[t]{3}{*}{$\begin{array}{l}\text { 4. Structure, systems } \\
\text { and processes }\end{array}$} & $\begin{array}{l}\text { 1. There is a low degree of hierarchy } \\
\text { (i.e. few hierarchical levels). }\end{array}$ & & \\
\hline & $\begin{array}{l}\text { 2. The organisation has a human } \\
\text { resource management system that } \\
\text { supports the shaping of } \\
\text { organisational culture and staff } \\
\text { recruitment, training, development } \\
\text { and retention. }\end{array}$ & & \\
\hline & $\begin{array}{l}\text { 3. There is a financial management } \\
\text { system that meets International } \\
\text { Financial Reporting Standards } \\
\text { (IFRS) or its equivalent. }\end{array}$ & $\begin{array}{l}\text { "SPC policies in these areas [accounting, auditing, internal control and } \\
\text { procurement] were benchmarked against international standards such as the } \\
\text { 'International Standards for Auditing' and 'International Financial Reporting } \\
\text { Standards"” (SPC, 2011a, p. 5). }\end{array}$ & $\square$ \\
\hline
\end{tabular}




\begin{tabular}{|c|c|c|c|}
\hline SUB-COMPONENT & INDICATOR & EVIDENCE & RATING \\
\hline & $\begin{array}{l}\text { 4. The organisation applies risk } \\
\text { management principles in its } \\
\text { decision-making processes. }\end{array}$ & & \\
\hline & $\begin{array}{l}\text { 5. The organisation has a centralised, } \\
\text { user-friendly internal data } \\
\text { management system. }\end{array}$ & & \\
\hline & $\begin{array}{l}\text { 6. The organisation has a user-friendly } \\
\text { project/program management } \\
\text { system (e.g. that supports staff to } \\
\text { identify, schedule and track } \\
\text { resources etc.). }\end{array}$ & & \\
\hline & $\begin{array}{l}\text { 7. There are mechanisms that support } \\
\text { vertical and horizontal } \\
\text { communication. }\end{array}$ & & \\
\hline & $\begin{array}{l}\text { 8. There are internal dispute resolution } \\
\text { protocols. }\end{array}$ & & \\
\hline $\begin{array}{l}\text { 5. Research and } \\
\text { collaboration } \\
\text { capacity }\end{array}$ & $\begin{array}{l}\text { 1. The organisation has plans and } \\
\text { policies that support research. }\end{array}$ & $\begin{array}{l}\text { SPC's } 2013-15 \text { corporate plan specifies research as one of the ways through } \\
\text { which SPC supports development in the Pacific. Their Public Health Division } \\
\text { has two programmes, one of which is "Research, Evidence and Information } \\
\text { Programme" (SPC, 2013, p. 9). } \\
\text { "Over the past } 25 \text { years, SOPAC 'The Commission' has developed the Science, } \\
\text { Technology and Resources (the SOPAC/STAR) Network (STAR); an } \\
\text { independent network to support the delivery by the international scientific } \\
\text { community of new and appropriate science and technology to the region. } \\
\text { In this, the international community of scientists and technologists provide a } \\
\text { substantial cost-free service to the region worth tens of millions of dollars } \\
\text { annually through inter-alia the costs of field surveys, including those for the } \\
\text { deployment of large research vessels, institutional laboratory and library costs } \\
\text { and salaries. } \\
\text { The establishment of SOPAC "The Division" of SPC enables the STAR to } \\
\text { associate itself with the SPC. SPC voiced 'unequivocal' commitment to } \\
\text { providing the opportunity to STAR to continue and expand its role and } \\
\text { encourages STAR to hold its regular meetings together with the Heads of } \\
\text { Applied Geoscience and Technology Meeting (the Technical Advisory Group } \\
\text { for the new SOPAC 'The Division'). STAR, being an independent, informal and }\end{array}$ & 可 \\
\hline
\end{tabular}




\begin{tabular}{|c|c|c|c|}
\hline SUB-COMPONENT & INDICATOR & EVIDENCE & RATING \\
\hline & & $\begin{array}{l}\text { entirely voluntary group of scientists will be encouraged through its Chair to } \\
\text { consider the SOPAC merger with SPC as an opportunity for becoming a premier } \\
\text { scientific conference of the Pacific Basin. The expansion of the role of STAR } \\
\text { under the auspices of SPC will be pursued to extend its benefits to an expanded } \\
\text { Membership and to include other major areas within SPC's mandate, for } \\
\text { example forestry, agriculture and fisheries" (SPC and SOPAC, 2010, p. 16). }\end{array}$ & \\
\hline & $\begin{array}{l}\text { 2. There are organisational funds } \\
\text { allocated for research. }\end{array}$ & $\begin{array}{l}\text { SPC's } 2013 \text { annual report includes five lines in the notes to the financial } \\
\text { statements that refer to projects that include research components (SPC, 2014f, } \\
\text { pp. 25-38). } \\
\text { The SOPAC Divisional } 2013 \text { Proposed Work Plan and Budget shows proposed } \\
\text { expenditure on fieldwork, studies and surveys for as: } \\
\text { 2013: CFP Units } 4,600,700 \\
\text { 2014: CFP Units: } 4,429,400 \\
\text { 2015: CFP Units: } 3,777,500 \\
\text { (SPC and SOPAC, } 2012, \text { p. } 2 \text { ). }\end{array}$ & $\nabla$ \\
\hline & $\begin{array}{l}\text { 3. The organisation has equipment, } \\
\text { expertise and/or resources (e.g. } \\
\text { access to journal articles etc.) for } \\
\text { research. }\end{array}$ & $\begin{array}{l}\text { In } 2009 \text { SPC chartered a vessel to undertake tuna tagging for research purposes. } \\
\text { Over two two month cruises } 7,786 \text { tuna were tagged (SPC, 2010b, p. 26). } \\
\text { Stable isotope analysis, along with data from analysis of fish stomach contents } \\
\text { (tuna, sharks, billfish and other species) carried out at SPC, and data on fat } \\
\text { content, allows researchers to determine predator-prey relationships in the } \\
\text { oceanic ecosystem and provides a better understanding of species interactions } \\
\text { and cascading effects of fishing activities and climate variations. This } \\
\text { information will be used in future stock assessments (SPC, 2010b, p. 27). } \\
\text { Pasha Carruthers is a Climate Change Adviser at SPC. The summary of her } \\
\text { background is, "A Conservation Professional with emphasis on global change } \\
\text { and sustainable development issues. Experienced in international negotiations, } \\
\text { participatory approaches, project proposal development, implementation and } \\
\text { management, with communities, municipal, state and national governments and } \\
\text { intergovernmental organisations. Post-graduate qualification for, and } \\
\text { implementation of, climate change vulnerability \& adaptation assessments and } \\
\text { pilot activities. Trained in ecology, coastal management, archaeology, mapping } \\
\text { procedures, analysis and reporting of scientific data. Twelve years with } \\
\text { Government of the Cook Islands National Environment Service in a variety of } \\
\text { roles related to MEAs implementation, culminating with three years as Island }\end{array}$ & $\square$ \\
\hline
\end{tabular}




\begin{tabular}{|c|c|c|c|}
\hline SUB-COMPONENT & INDICATOR & EVIDENCE & RATING \\
\hline & & $\begin{array}{l}\text { Futures Division Manager. Four years with SPC as Technical Adviser to the } \\
\text { European Union Funded Global Climate Change Alliance Pacific Small Islands } \\
\text { States Project, particularly water security and health activities" (Carruthers, } \\
\text { 2015). }\end{array}$ & \\
\hline & $\begin{array}{l}\text { 4. The organisation's current strategic } \\
\text { plan (or a similar document) outlines } \\
\text { plans for collaboration with multiple } \\
\text { stakeholders on adaptation-related } \\
\text { initiatives. }\end{array}$ & $\begin{array}{l}\text { "SPC works with other CROP agencies to address the effects of climate change } \\
\text { and reduce the risks from disasters in the Pacific Islands" (SPC, 2013, p. 11). } \\
\text { While not focused specifically on adaptation, as part of its results framework } \\
\text { SPC is "Fostering action-focused collaboration with worthy partners for more } \\
\text { effective service delivery" (emphasis added) (SPC, 2013, p. 17). }\end{array}$ & $\square$ \\
\hline \multicolumn{4}{|c|}{ 2. Project/Program Effectiveness-GCCA:PSIS } \\
\hline 1. Needs and goals & $\begin{array}{l}\text { 1. The project documents contain } \\
\text { evidence that the project/program } \\
\text { fills an existing need with relation to } \\
\text { climate change adaptation. }\end{array}$ & $\begin{array}{l}\text { The Global Climate Change Alliance is an EU funded program to support and } \\
\text { strengthen dialogue, cooperation and exchange of experiences among Least } \\
\text { Developed Countries (LDCs) and Small Island Developing States (SIDS). The } \\
\text { project acknowledges the many particular development challenges faced by } \\
\text { SIDS, which are exacerbated by climate change and climate variability (SPC, } \\
\text { 2012, p. 1). } \\
\text { For the fragile and exposed low lying atolls of the Cook Islands (Manihiki, } \\
\text { Rakahanga, Penrhyn, Pukapuka, Palmerston) climate change is an ever present } \\
\text { reality. Manihiki atoll is a classic example of the vulnerability of these atolls to } \\
\text { extreme weather events. The atoll had always been considered to lie outside of } \\
\text { the main cyclone belt. However, it was devastated by Cyclone Martin in } 1997 \text {. } \\
\text { A number of waves swept across the whole island and } 19 \text { people lost their lives" } \\
\text { (SPC, 2011b, p. 2). } \\
\text { "Planning for adaptation to the impacts of climate change requires an ability to } \\
\text { monitor changes at local levels within the atoll communities. This allows for } \\
\text { planning adaptive management for pearl farming and inshore fisheries. } \\
\text { The communities on these atolls are small, and livelihood activities are a family } \\
\text { affair, with men, women and children all participating in different aspects of the } \\
\text { activity, be it pearl farming, fishing, or small scale agriculture. Thus the entire } \\
\text { populations will directly benefit from an ecosystem which is more resilient to } \\
\text { the impacts of climate change. } \\
\text { Urgent action is required to build resilience to climate change, and this project } \\
\text { opportunity is very timely. The project will result in the remote communities on }\end{array}$ & $\nabla$ \\
\hline
\end{tabular}




\begin{tabular}{|c|c|c|c|}
\hline SUB-COMPONENT & INDICATOR & $\begin{array}{l}\text { EVIDENCE } \\
\end{array}$ & RATING \\
\hline & & $\begin{array}{l}\text { these atolls being in a much better position to survive in this vulnerable } \\
\text { environment and in the face of changes to their climate" (SPC, 2011b, p. 2). }\end{array}$ & \\
\hline & $\begin{array}{l}\text { 2. The project/program's adaptation } \\
\text { components could be considered } \\
\text { 'transformational' (i.e. the } \\
\text { project/program focusses on "larger, } \\
\text { more profound system changes" and } \\
\text { requires a "paradigm shift" in the } \\
\text { way it is framed and implemented). }\end{array}$ & $\begin{array}{l}\text { In the Cook Islands, "at least one new effective communication tool will be } \\
\text { prepared collaboratively and used widely in the communities during the duration } \\
\text { of the project" (SPC and Government of the Cook Islands, 2012, p. 15). }\end{array}$ & \\
\hline & $\begin{array}{l}\text { 3. Climate change adaptation is a goal } \\
\text { of the project/program. }\end{array}$ & $\begin{array}{l}\text { "SPC and the European Union have agreed to support the governments of nine } \\
\text { small Pacific countries, namely Cook Islands, Federated States of Micronesia, } \\
\text { Kiribati, Marshall Islands, Nauru, Niue, Palau, Tonga and Tuvalu, in their } \\
\text { efforts to tackle the adverse effects of climate change. This initiative is called } \\
\text { the Global Climate Change Alliance: Pacific Small Island States" (emphasis } \\
\text { added) (SPC, 2012, p. 1). } \\
\text { The purpose of the project is to, "To promote a long term/strategic approach to } \\
\text { adaptation planning and budgets and to pave the way towards more effective } \\
\text { and coordinated aid delivery modalities at national and at regional level" } \\
\text { (emphasis added) (GCCA and SPC, 2012, p. 1). }\end{array}$ & $\nabla$ \\
\hline & $\begin{array}{l}\text { 4. The project/program's goals reflect } \\
\text { the long-range impacts of climate } \\
\text { change. }\end{array}$ & $\begin{array}{l}\text { The purpose of the project is to, "To promote a long term/strategic approach to } \\
\text { adaptation planning and budgets and to pave the way towards more effective } \\
\text { and coordinated aid delivery modalities at national and at regional level" } \\
\text { (emphasis added) (GCCA and SPC, 2012, p. 1). }\end{array}$ & $\square$ \\
\hline & $\begin{array}{l}\text { 5. The project/program's objectives } \\
\text { relating to climate change adaptation } \\
\text { are specific, measurable, achievable, } \\
\text { realistic and time-bound (SMART). }\end{array}$ & $\begin{array}{l}\text { The overall objective of the project is to provide support to the governments of } \\
\text { nine Pacific small island developing states so they can address negative impacts } \\
\text { of climate change. The indicators for this objective are: } \\
\text { "1. Ten new activities that address country requests for climate change } \\
\text { adaptation undertaken in an effective and sustainable manner. } \\
\text { 2. Capacity of a minimum of } 40 \text { national sector specialists for integrating climate } \\
\text { change adaptation into at least three sectors built from minimal level to moderate } \\
\text { level" (GCCA and SPC, 2012, p. 1). }\end{array}$ & $\diamond$ \\
\hline & $\begin{array}{l}\text { 6. Member Countries were involved in } \\
\text { developing the climate change } \\
\text { adaptation components of the } \\
\text { project/program. }\end{array}$ & $\begin{array}{l}\text { The logframe for the GCCA:PSIS project includes as an indicator that, "[t]en } \\
\text { new activities that address country requests for climate change adaptation [will } \\
\text { be] undertaken in an effective and sustainable manner" (GCCA and SPC, 2012, } \\
\text { p. 1). }\end{array}$ & $\square$ \\
\hline
\end{tabular}




\begin{tabular}{|c|c|c|c|}
\hline SUB-COMPONENT & INDICATOR & EVIDENCE & RATING \\
\hline & & $\begin{array}{l}\text { As an example, the Government of the Cook Islands is one of the authors of the } \\
\text { Cook Islands Project Design Document (Emphasis added) (SPC and } \\
\text { Government of the Cook Islands, 2012). } \\
\text { "In Nauru delays were experienced with obtaining Government endorsement of } \\
\text { the Project Design Document. This was discussed at the Fourth Steering } \\
\text { Committee Meeting in June 2014, when Nauru decided to move the project } \\
\text { focus from household water conservation measures to community water } \\
\text { conservation measures" (SPC, 2014c, p. 9). }\end{array}$ & \\
\hline \multirow[t]{2}{*}{ 2. Scope } & $\begin{array}{l}\text { 1. The project/program addresses } \\
\text { multiple climate or climate-induced } \\
\text { vulnerabilities (e.g. vulnerability to } \\
\text { sea-level rise, increased sea surface } \\
\text { and air temperature, changing } \\
\text { rainfall patterns etc.). }\end{array}$ & $\begin{array}{l}\text { "The activities [in the Cook Islands] seek to strengthen existing environmental } \\
\text { monitoring, including water quality; to provide information that will assist pearl } \\
\text { farmers to improve their farming practices, and avoid disease outbreaks and } \\
\text { stress to the oysters due to present environmental conditions and future projected } \\
\text { conditions under climate change" (SPC and Government of the Cook Islands, } \\
\text { 2012, p. 1). }\end{array}$ & $\nabla$ \\
\hline & $\begin{array}{l}\text { 2. The project/program addresses } \\
\text { multiple non-climate-induced } \\
\text { vulnerabilities } \quad \text { (e.g. poverty, } \\
\text { deforestation etc.). }\end{array}$ & $\begin{array}{l}\text { The GCCA:PSIS project in the Republic of the Marshall Islands (RMI): } \\
\text { "Protecting atoll habitability, land and infrastructure in Ailinglaplap, Marshall } \\
\text { Islands" recognises the vulnerabilities detailed in RMI's JNAP, including "1. } \\
\text { Sparse and scattered nature of islands and atolls, making communication and } \\
\text { transportation to outer islands more difficult [and,] 2. Outbreaks of disease via } \\
\text { contamination of water is not uncommon - an issue that is exacerbated by the } \\
\text { high population densities of the urban centres" (GCCA et al., 2014, p. 6). } \\
\text { "The government of RMI selected the Woja road and causeway project as the } \\
\text { focus for the GCCA: PSIS project, based on an OEPPC vulnerability survey } \\
\text { (which included consultation with the local community) indicating the area is } \\
\text { undergoing active erosion and which could divide the islands, thereby impacting } \\
\text { copra production, access to schools and health services for the community" } \\
\text { (emphasis added) (GCCA et al., 2014, p. 8). } \\
\text { The logical framework for the Cook Islands project includes, as a key results } \\
\text { area, a study of livelihood activities that relate to marine resources, which } \\
\text { includes revising the "Existing Pearl Economic Model" (SPC and Government } \\
\text { of the Cook Islands, 2012, p. 20). }\end{array}$ & $\square$ \\
\hline $\begin{array}{l}\text { 3. Logic, design and } \\
\text { adequacy }\end{array}$ & $\begin{array}{l}\text { 1. The logic/design of the } \\
\text { project/program's climate change } \\
\text { adaptation components is evidence- } \\
\text { based, in the context of SIDS. }\end{array}$ & $\begin{array}{l}\text { "Provision of training in project appraisal and management will help countries } \\
\text { identify effective adaptation measures that can be supported by development } \\
\text { partners. The design and implementation of climate change adaptation projects } \\
\text { in each country is part of this initiative" (SPC, 2012, p. 3). }\end{array}$ & $\diamond$ \\
\hline
\end{tabular}




\begin{tabular}{|c|c|c|c|}
\hline SUB-COMPONENT & INDICATOR & EVIDENCE & RATING \\
\hline & & $\begin{array}{l}\text { "Marshall Islands (RMI) } \\
\text { The following activities are being supported under the European Union funded } \\
\text { GCCA:PSIS project in RMI. } \\
\text { Climate change adaptation project } \\
\text { RMI has chosen to focus its adaptation project on enhancing coastal protection. } \\
\text { Over the long term, coastal erosion and inundation threatens many of the } \\
\text { country's low-lying atolls, and RMI has identified the need to enhance its ability } \\
\text { to design and implement appropriate and sustainable coastal protection } \\
\text { measures. The adaptation project under the GCCA:PSIS project focuses on an } \\
\text { outer atoll, Aililnglaplap, and the construction of a causeway to maintain access } \\
\text { between two islands in an area of coastal erosion. } \\
\text { The project is also intended as a blueprint for a best practice guideline for coastal } \\
\text { protection projects in future. In addition, it will support national stakeholder } \\
\text { dialogue and planning for a building code or similar that can help guide future } \\
\text { planning decisions, to reduce risks from climate change and extreme events" } \\
\text { (GCCA, 2012). }\end{array}$ & \\
\hline & $\begin{array}{l}\text { 2. The project documents contain } \\
\text { evidence that the logic/design of the } \\
\text { project/program's climate change } \\
\text { adaptation components is an } \\
\text { effective means to achieve its } \\
\text { objectives. }\end{array}$ & $\begin{array}{l}\text { The lessons learnt workshop that was held in September } 2015 \text { reports a number } \\
\text { of concerns that stakeholders had relating to things such as budget overruns, } \\
\text { poor funding allocations, weak coordination and lack of early consultation with } \\
\text { community stakeholders and project managers. Things that stakeholders } \\
\text { reported positively on included that national, state and local parties worked } \\
\text { together to achieve project aims, that there was political support for the projects } \\
\text { and that there were tangible outputs that led to direct improvements in } \\
\text { livelihoods (GCCA and SPC, 2015, pp. 45-47). } \\
\text { "The government of RMI selected the Woja road and causeway project as the } \\
\text { focus for the GCCA:PSIS project, based on an OEPPC vulnerability survey } \\
\text { (which included consultation with the local community) indicating the area is } \\
\text { undergoing active erosion and which could divide the islands, thereby impacting } \\
\text { copra production, access to schools and health services for the community" } \\
\text { (emphasis added) (GCCA et al., 2014, p. 8). }\end{array}$ & $\diamond$ \\
\hline
\end{tabular}




\begin{tabular}{|c|c|c|c|}
\hline SUB-COMPONENT & INDICATOR & EVIDENCE & RATING \\
\hline & & $\begin{array}{l}\text { The Cook Islands project began with a review of climate change projects and } \\
\text { programs to provide a background for identifying a focus area for this project. } \\
\text { This was followed by discussions with country representatives about adaptation } \\
\text { needs in the Cook Islands. Finally, prior to preparing a concept note for the } \\
\text { project, there were discussions with ministries and line agencies and the Prime } \\
\text { Minister's Office, to choose the marine resources sector (SPC and Government } \\
\text { of the Cook Islands, 2012, p. 12). } \\
\text { "This project is consistent with the climate change adaptation needs and } \\
\text { priorities for the Cook Islands as identified in the Joint National Action Plan for } \\
\text { Climate Change Adaptation and Disaster Risk Management and supported by } \\
\text { intensive participatory consultations" (SPC and Government of the Cook } \\
\text { Islands, 2012, p. 1). }\end{array}$ & \\
\hline 4. Resources & $\begin{array}{l}\text { 1. Staff members are assigned } \\
\text { exclusively to the project/program. }\end{array}$ & $\begin{array}{l}\text { The GCCA:PSIS projects use national staff from the implementing countries: } \\
\text { "The project will be managed and implemented by MMR and coordinated at the } \\
\text { national level by the Office of the Prime Minister through the Climate Change } \\
\text { Cook Islands Office" (SPC and Government of the Cook Islands, 2012). } \\
\text { "In RMI, the GCCA PSIS project has supported: } \\
\text { - A Climate Change Finance Assessment for the Marshall Islands. This } \\
\text { in-depth study was conducted in 2014, and examines the extent to which } \\
\text { RMI has already accessed resources for climate change objectives, how } \\
\text { its domestic systems - including policies, institutional arrangements and } \\
\text { public financial management systems - could be adjusted so as to make } \\
\text { more effective use of available finance and also increase future access } \\
\text { to climate finance. The GCCA: PSIS project contributed staff and funds } \\
\text { towards this project, led by PIFS and in partnership with other regional } \\
\text { organisations (see the Finance Assessment executive summary and final } \\
\text { report). } \\
\text { An assessment of the extent to which climate change has been } \\
\text { mainstreamed into national and sectoral policies and plans (see a } \\
\text { summary of the assessment). } \\
\text { Training and capacity building } \\
\text { As part of the GCCA:PSIS project, several kinds of training have been delivered } \\
\text { in RMI: }\end{array}$ & $\diamond$ \\
\hline
\end{tabular}




\begin{tabular}{|c|c|c|c|}
\hline SUB-COMPONENT & INDICATOR & EVIDENCE & RATING \\
\hline & & $\begin{array}{l}\text { - Proposal preparation and log frame analysis - July } 2013 \text { (see the } \\
\text { workshop report, impact evaluation and learner's guide) } \\
\text { - Sub-regional North Pacific climate change and the media training- } \\
\text { October } 2012 \text { (see the workshop report) } \\
\text { - Sub-regional North Pacific training on utilising the Pacific Climate } \\
\text { Change Portal- February } 2013 \text { (see the workshop report) } \\
\text { - First National Climate Change Dialogue - September } 2014 \text { (see the } \\
\text { dialogue report)" (emphasis added) (GCCA, 2012). }\end{array}$ & \\
\hline & $\begin{array}{l}\text { 2. The project/program team includes } \\
\text { staff members with qualifications } \\
\text { and experience in climate change } \\
\text { adaptation. }\end{array}$ & $\begin{array}{l}\text { One of the activities for the second key results area is to provide two qualified } \\
\text { personnel, employed by the ministry of marine resources (SPC and Government } \\
\text { of the Cook Islands, 2012, p. 15). } \\
\text { Dr Graham Sem (a lead author of Chapter } 16 \text { (Small Islands) of the IPCC's } \\
\text { Climate Change 2007: Working Group II: Impacts, Adaptation and } \\
\text { Vulnerability, and member of the UNFCCC Secretariat (PNG)) is a member of } \\
\text { the project oversight committee. } \\
\text { Pasha Carruthers is a Climate Change Adviser in the Climate Change Unit } \\
\text { (USAID Project and EU-GCCA Project) (SPC-SOPAC, 2015). The summary } \\
\text { of her background is, "A Conservation Professional with emphasis on global } \\
\text { change and sustainable development issues. Experienced in international } \\
\text { negotiations, participatory approaches, project proposal development, } \\
\text { implementation and management, with communities, municipal, state and } \\
\text { national governments and intergovernmental organisations. Post-graduate } \\
\text { qualification for, and implementation of, climate change vulnerability \& } \\
\text { adaptation assessments and pilot activities. Trained in ecology, coastal } \\
\text { management, archaeology, mapping procedures, analysis and reporting of } \\
\text { scientific data. Twelve years with Government of the Cook Islands National } \\
\text { Environment Service in a variety of roles related to MEAs implementation, } \\
\text { culminating with three years as Island Futures Division Manager. Four years } \\
\text { with SPC as Technical Adviser to the European Union Funded Global Climate } \\
\text { Change Alliance Pacific Small Islands States Project, particularly water security } \\
\text { and health activities" (emphasis added) (Carruthers, 2015). }\end{array}$ & $\nabla$ \\
\hline & $\begin{array}{l}\text { 3. The project/program team includes } \\
\text { staff members with qualifications }\end{array}$ & $\begin{array}{l}\text { Vuki Buadromo is a Project Manager at SPC. Prior to joining SPC she worked } \\
\text { for four years at the Pacific Islands Forum Secretariat where she "Managed the } \\
\text { implementation an annual grant of USD500,000 which supports a regional }\end{array}$ & $\nabla$ \\
\hline
\end{tabular}




\begin{tabular}{|c|c|c|c|}
\hline SUB-COMPONENT & INDICATOR & $\begin{array}{l}\text { EVIDENCE } \\
\end{array}$ & RATING \\
\hline & $\begin{array}{l}\text { and experience in project/program } \\
\text { management. }\end{array}$ & $\begin{array}{l}\text { scholarship programme available to Forum island countries over four years. } \\
\text { Management of the scheme involved monitoring and evaluation of the } \\
\text { programme; managing project budgets; servicing committee meetings; liaising } \\
\text { with regional stakeholders; and reporting programme outputs to the } \\
\text { development partner, Forum member countries and the management committee } \\
\text { on an annual basis. } \\
\text { >Managed and coordinated the successful implementation of a multi-year grant } \\
\text { (USD 300,000) from the Republic of Korea. The grant was co-implemented by } \\
\text { two technical agencies (the Fiji School of Medicine and the Seoul National } \\
\text { University Hospital) which supported the successful training of } 25 \text { health care } \\
\text { workers from the region in primary health care. } \\
\text { >Managed of the Pacific Islands Development Cooperation Fund - } \\
\text { Responsibilities included coordinating CROP project proposals and reports; } \\
\text { developing and facilitating agreements between the government of Japan and } \\
\text { implementing technical agencies; management/coordination of project funds; } \\
\text { monitoring, evaluating and reporting on project implementation; and reporting } \\
\text { to the Japan Management Committee on the status of projects and funds on an } \\
\text { annual basis. } \\
\text { >Management of special funding facilities for Forum member countries } \\
\text { (Smaller Islands Development Fund, Forum Secretariat Fellowship Scheme, } \\
\text { Short Term Technical Advisory Service)" (emphasis added) (Buadromo, 2015). } \\
\text { Pasha Carruthers is a Climate Change Adviser in the Climate Change Unit } \\
\text { (USAID Project and EU-GCCA Project) (SPC-SOPAC, 2015). The summary } \\
\text { of her background is, "A Conservation Professional with emphasis on global } \\
\text { change and sustainable development issues. Experienced in international } \\
\text { negotiations, participatory approaches, project proposal development, } \\
\text { implementation and management, with communities, municipal, state and } \\
\text { national governments and intergovernmental organisations". }\end{array}$ & \\
\hline & $\begin{array}{l}\text { 4. The project documents contain } \\
\text { evidence that there are sufficient } \\
\text { staff members to achieve the } \\
\text { project/program objectives. }\end{array}$ & & \\
\hline & $\begin{array}{l}\text { 5. The project documents contain } \\
\text { evidence that there is sufficient }\end{array}$ & $\begin{array}{l}\text { "The Woja site was also considered most likely to be financially viable to tackle } \\
\text { with the budget available under the GCCA:PSIS project" (GCCA, 2012, p. 8). }\end{array}$ & $\diamond$ \\
\hline
\end{tabular}




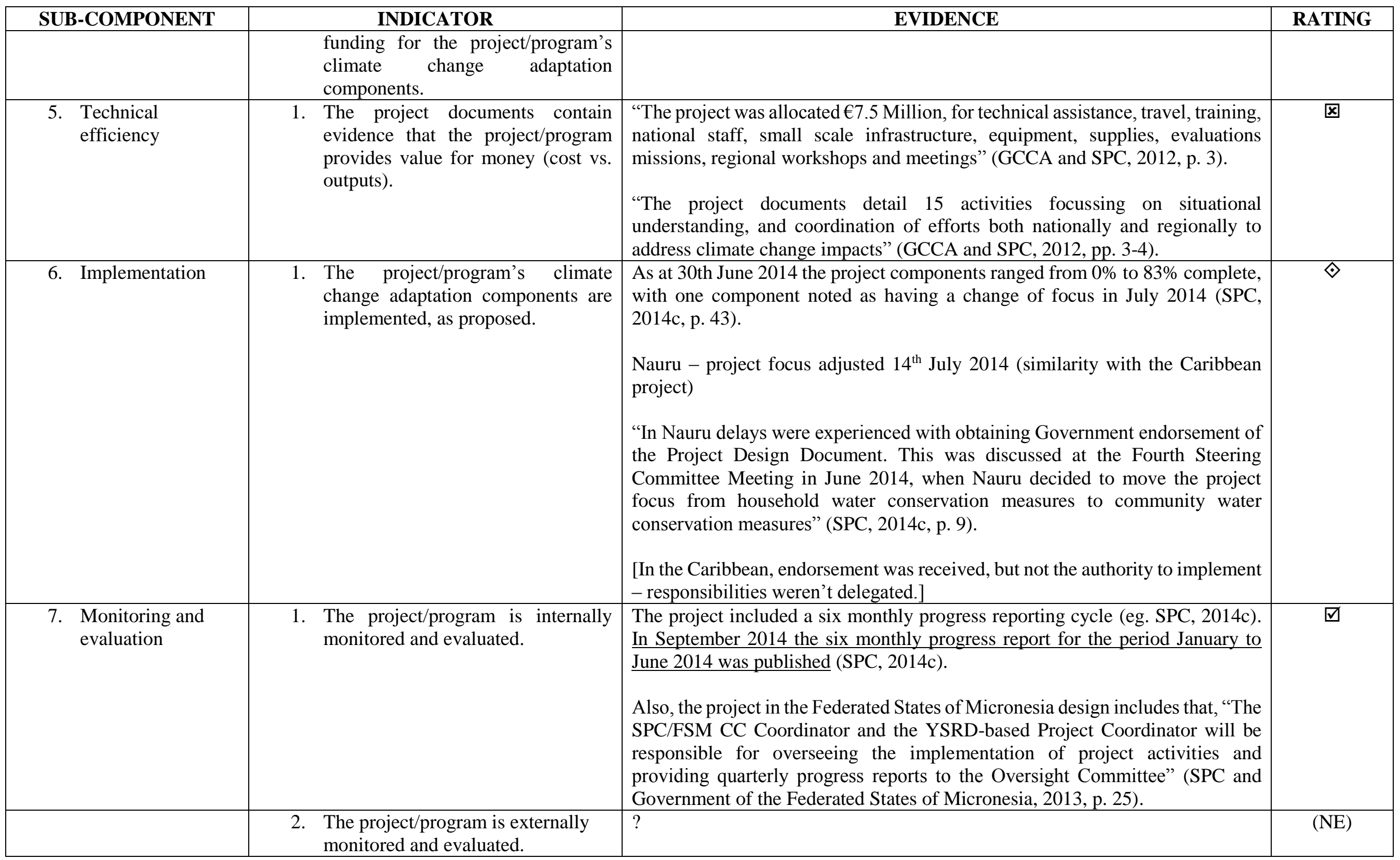




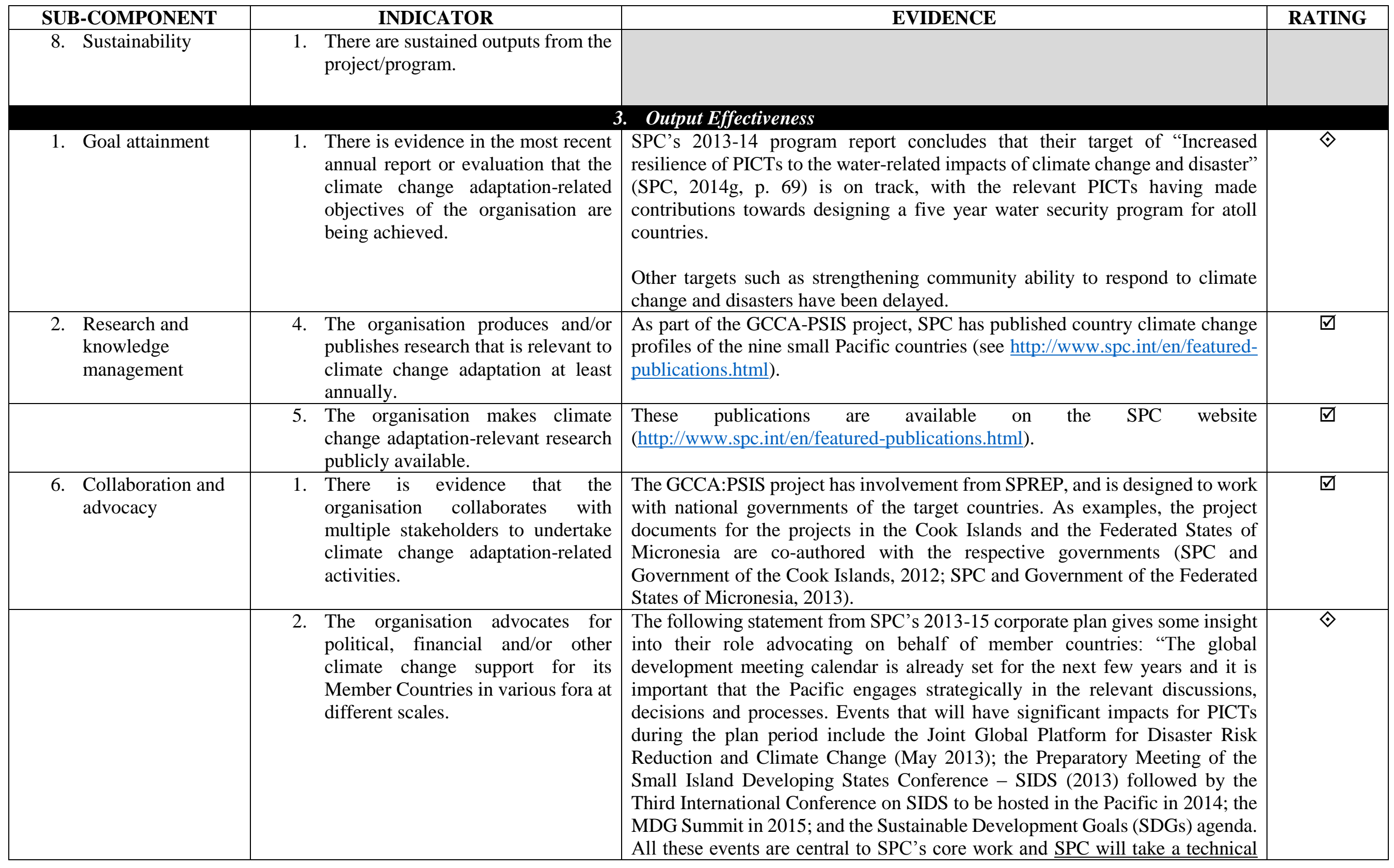




\begin{tabular}{|c|c|c|c|}
\hline \multirow[t]{2}{*}{ SUB-COMPONENT } & INDICATOR & EVIDENCE & RATING \\
\hline & & $\begin{array}{l}\text { leadership role in supporting PICTs in these and other areas" (emphasis added) } \\
\text { (SPC, 2013, p. 27). }\end{array}$ & \\
\hline $\begin{array}{l}\text { 4. Education and } \\
\text { training }\end{array}$ & $\begin{array}{l}\text { 1. The organisation undertakes climate } \\
\text { change adaptation stakeholder } \\
\text { and/or public awareness activities. }\end{array}$ & $\begin{array}{l}\text { With support from a number of projects and agencies, including SPC- EU } \\
\text { GCCA: PSIS, on "Wednesday } 15 \text { October } 2014 \text {, Kiribati will be joining hands } \\
\text { with over } 200 \text { million people in over } 100 \text { countries around the world to celebrate } \\
\text { Global Hand Washing Day with the theme 'Clean Hands Save Lives'. The event } \\
\text { will be held in Bairiki Square in South Tarawa from } 11 \text { am to 3pm in the presence } \\
\text { of Secretaries, Diplomats, Heads of UN agencies, members of community and } \\
\text { school students" (Office of the President of Kiribati, 2015). } \\
\text { "In a timely gesture, two more television stations in the Pacific Island region } \\
\text { will soon be airing the Secretariat of the Pacific Community's flagship TV show, } \\
\text { The Pacific Way.... } \\
\text { To view the first four episodes of the show for 2015, see The Pacific Way } \\
\text { playlist on YouTube: } \\
\text { - Episode 1: Youth at Work \& 20th Anniversary Highlights 3rd SPC } \\
\text { Conference: https://youtu.be/7UtXfJlyE2c } \\
\text { Episode 2: Empowering Communities in RMI, Palau \& FSM: } \\
\text { https://youtu.be/f_Ur9LDoGPE } \\
\text { Episode 3: National Adaptation Programme of Action to Climate } \\
\text { Change (NAPA) in Tuvalu: https://youtu.be/UGtlSLXXIOs } \\
\text { Episode 4: Building Resilient Communities in Tonga (USAID) \& } \\
\text { GCCA: PSIS Kiribati Environmental Health Surveillance: } \\
\text { https://youtu.be/AbzMAXhV8H0“(emphasis added) (SPC, 2015b). }\end{array}$ & 甲 \\
\hline & $\begin{array}{l}\text { 2. The organisation develops and/or } \\
\text { implements training programs for } \\
\text { stakeholders in issues related to } \\
\text { climate change adaptation. }\end{array}$ & $\begin{array}{l}\text { There are a variety of training resources published on the SPC website. For } \\
\text { example a tool for integrating gender concerns into weather and climate hazard } \\
\text { assessments } \\
\text { http://www.spc.int/images/publications/en/Divisions/CC/Tools.pdf). } \\
\text { From the } 20^{\text {th }}-22^{\text {nd }} \text { June } 2012 \text { the "Secretariat of the Pacific Community (SPC) } \\
\text { held a training session on gender and climate change for Fiji officers from } \\
\text { government ministries and NGOs. It aimed at strengthening participants' } \\
\text { understanding of the gender analysis approach so that they could apply it in the } \\
\text { context of climate change. According to SPC, understanding the different roles } \\
\text { of women, men, youth and children, is critical to reducing vulnerability and }\end{array}$ & V \\
\hline
\end{tabular}




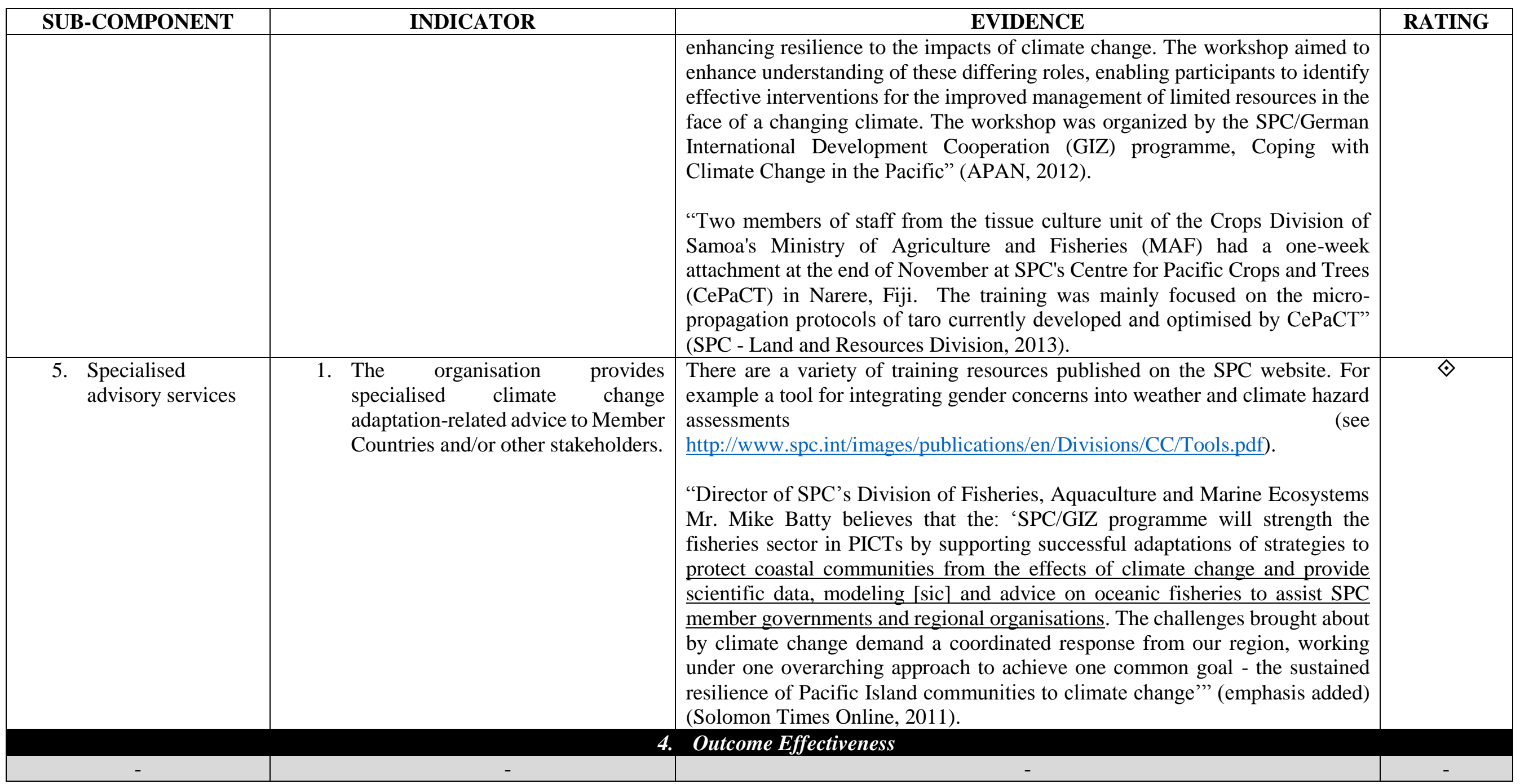

Appendix 4: Application of FAROCCCA to SPC (cont'd) 
Appendix 5: Application of FAROCCCA to SPREP

\begin{tabular}{|c|l|}
\hline \multicolumn{2}{|c|}{ RATING SYSTEM } \\
\hline $\boldsymbol{\otimes}$ & No \\
\hline$\diamond$ & To some extent \\
\hline$\square$ & Yes \\
\hline$(\mathrm{NE})$ & No evidence \\
\hline & Perceptual indicator or indicator not rated in this paper \\
\hline
\end{tabular}

\begin{tabular}{|c|c|c|c|}
\hline SUB-COMPONENT & INDICATOR & EVIDENCE & RATING \\
\hline 1. Goals & $\begin{array}{l}\text { 1. Climate change adaptation was } \\
\text { an initial goal of the organisation. }\end{array}$ & $\begin{array}{l}\text { 1. Input Effectiveness } \\
\text { In the } 2,400 \text { word agreement establishing SPREP (SPREP, 1993), recognition of the } \\
\text { overlaps between people and the environment consists of four uses of the word } \\
\text { 'sustainable'. The organisation's original mission statement was "To promote } \\
\text { cooperation in the Pacific region and provide assistance in order to protect and } \\
\text { improve its environment and to ensure sustainable development for present and future } \\
\text { generations" (SPREP, 2011a). }\end{array}$ & $\boldsymbol{x}$ \\
\hline & $\begin{array}{l}\text { 2. Climate change adaptation is a } \\
\text { current goal of the organisation. }\end{array}$ & $\begin{array}{l}\text { SRPEP's 2011-15 Strategic Plan lists climate change as its first strategic priority in } \\
\text { (SPREP, 2011b, p. 3), with the specified goal under this priority heading being to } \\
\text { strengthen member capacities to respond to climate change (SPREP, 2011b). "By } \\
2015 \text {, all Members will have strengthened capacity to respond to climate change } \\
\text { through policy improvement, implementation of practical adaptation measures, } \\
\text { enhancing ecosystem resilience to the impacts of climate change, and implementing } \\
\text { initiatives aimed at achieving low-carbon development" (emphases added). }\end{array}$ & $\nabla$ \\
\hline & $\begin{array}{l}\text { 3. The current strategic plan } \\
\text { contains specific climate change } \\
\text { adaptation objectives. }\end{array}$ & $\begin{array}{l}\text { SPREP's 2011-15 Strategic Plan includes } 15 \text { climate change targets ranging from } \\
\text { "By 2015, all Members can refer to accurate emissions inventories and assessments } \\
\text { of their technical needs" (SPREP, 2011b, p. 19) to "At least } 10 \text { PICT Members have } \\
\text { mainstreamed climate change adaptation, including ecosystem based approaches, and } \\
\text { risk reduction considerations in their national sustainable development strategies } \\
\text { (NSDS) or equivalent and resources have been mobilised for their implementation" } \\
\text { (emphasis added) (SPREP, 2011a, p. 17). } \\
\text { Pacific interpretation of 'mainstreaming' } \rightarrow \text { "Climate change adaptation, including } \\
\text { ecosystem-based approaches, is mainstreamed in national and sectoral polices, } \\
\text { strategies and plans, and implemented through coordinated institutional } \\
\text { arrangements supported by enabling environments at all levels and sectors; } \\
\text { adaptation and mitigation activities are integrated to prevent any contrary ("perverse') }\end{array}$ & $\nabla$ \\
\hline
\end{tabular}




\begin{tabular}{|c|c|c|c|}
\hline \multirow[t]{2}{*}{ SUB-COMPONENT } & INDICATOR & $\begin{array}{l}\text { EVIDENCE } \\
\end{array}$ & RATING \\
\hline & & $\begin{array}{l}\text { impacts on ecosystems" (https://www.sprep.org/sprep-meeting/pacific-environment- } \\
\text { forum). }\end{array}$ & \\
\hline & $\begin{array}{l}\text { There is no other regional } \\
\text { organisation with similar climate } \\
\text { change adaptation goals. }\end{array}$ & $\begin{array}{l}\text { SPC medium term climate change goal: "Capacity to respond to climate change, } \\
\text { disasters and emergencies strengthened" (SPC, 2013, p. 2). } \\
\text { SPREP climate change goal: "By 2015, all Members will have strengthened capacity } \\
\text { to respond to climate change through policy improvement, implementation of } \\
\text { practical adaptation measures, enhancing ecosystem resilience to the impacts of } \\
\text { climate change, and implementing initiatives aimed at achieving low-carbon } \\
\text { development" (SPREP, 2011b, p. 16). } \\
\text { The Pacific Centre for Environment and Sustainable Development (PACE-SD) at the } \\
\text { University of the South Pacific has the following mission: "To work with all other } \\
\text { relevant sections of the university, regional and international organisations and } \\
\text { governments to promote environmentally friendly climate change adaptation and } \\
\text { sustainable development through innovative and cost-effective approaches" } \\
\text { (http://www.usp.ac.fj/index.php?id=11354\&type=98). } \\
\text { *Overlapping missions of SPREP and SPC; SRPEP is environment-focussed- } \\
\text { ecosystems resilience (related to original mission; SPC is more disaster-focused, } \\
\text { probably working in a comprehensive disaster management framework* }\end{array}$ & 凶 \\
\hline \multirow[t]{2}{*}{$\begin{array}{l}\text { 2. Governance and } \\
\text { leadership }\end{array}$} & $\begin{array}{l}\text { 1. The Board provides visionary } \\
\text { leadership and strategic direction. }\end{array}$ & & \\
\hline & $\begin{array}{l}\text { 2. The organisation evaluates } \\
\text { organisational performance at } \\
\text { least annually. }\end{array}$ & $\begin{array}{l}\text { "Progress towards the goals and outcomes of the }[2011-2015] \text { Strategic Plan will } \\
\text { be evaluated against key performance indicators annually through the performance } \\
\text { monitoring and evaluation report to SPREP Meetings: these indicators will be } \\
\text { monitoring tool for tracking progress" (SPREP, 2011b, p. 33). } \\
\text { Progress will be evaluated annually against key performance indicators through the } \\
\text { performance monitoring and evaluation report to SPREP Meetings; these indicators } \\
\text { will be used as a monitoring tool to measure the impact of the Secretariat's work and } \\
\text { track progress (SPREP, 2011b, p. 6). } \\
\text { SPREP publishes annual monitoring and evaluation reports that are based on the } \\
\text { approved work plan and budget for the year and question, with this stemming from } \\
\text { the strategic plan. For example, the target, "At least } 10 \text { PICT Members have } \\
\text { mainstreamed climate change adaptation, including ecosystem based approaches, and } \\
\text { risk reduction considerations in their national sustainable development strategies }\end{array}$ & $\square$ \\
\hline
\end{tabular}




\begin{tabular}{|c|c|c|c|}
\hline SUB-COMPONENT & INDICATOR & $\begin{array}{l}\text { EVIDENCE } \\
\text { (NSDS) or equivalent and resources have been mobilised for their implementation" } \\
\text { appears first in SPREP's 2011-2015 strategic plan (SPREP, 2011b, p. 17), and later } \\
\text { in the 2014 Approved Work Programme and Budget (SPREP, 2013c, p. 11), with a } \\
\text { budget of US\$1,022,325 attached, and finally in the 2014 Performance and } \\
\text { Monitoring Evaluation Report for 2014 (SPREP, 2015e, p. 8) with an actual } \\
\text { expenditure of US \$909,486 and with the target 100\% complete. }\end{array}$ & RATING \\
\hline & $\begin{array}{l}\text { 3. Executive management (can also } \\
\text { include members of the } \\
\text { Board/Governing Body) } \\
\text { decision-making is done by } \\
\text { consensus or majority vote. }\end{array}$ & $\begin{array}{l}\text { The SPREP Meeting Rules of Procedure specify that decision-making will be } \\
\text { achieved through consensus to ensure each member has a voice (SPREP, 1995, Rule } \\
\text { 11). }\end{array}$ & $\square$ \\
\hline & $\begin{array}{l}\text { 4. Executive management staff (can } \\
\text { also include members of the } \\
\text { Board/Governing Body) are } \\
\text { qualified and/or equipped to } \\
\text { achieve the goals of the } \\
\text { organisation. }\end{array}$ & $\begin{array}{l}\text { DG requires a Master's degree in management/development/environment or a related } \\
\text { field. Also } 15 \text { years' significant and relevant experience at senior executive level. } \\
\text { Extensive high level experience and competency negotiating with governments and } \\
\text { donors and development partners in and outside the region (SPREP, 2015b). } \\
\text { DG (2009-2015) education: } \\
\text { "The Australian National University } \\
\text { Bachelor of Science (Forestry), Forest Management, Ecology and Environmental } \\
\text { Management } \\
1974 \text { - } 1977 \\
\text { University of Canberra } \\
\text { Post Graduate Diploma in Resource Management, Natural Resource Policy and } \\
\text { Management } \\
1981-1982 \\
\text { Harvard Business School Executive Education } \\
\text { Executive Development Programme, Advanced Executive Management and } \\
\text { Leadership } \\
2000 \text { - Present" } \\
\text { DG (2009-2015) experience: }\end{array}$ & $\square$ \\
\hline
\end{tabular}




\begin{tabular}{|c|c|c|c|}
\hline SUB-COMPONENT & INDICATOR & EVIDENCE & RATING \\
\hline & & $\begin{array}{l}\text { "Manager, Natural Resource Management Division } \\
\text { National Parks and Wildlife Service, New South Wales, Australia } \\
\text { March } 1983 \text { - October } 1990 \text { ( } 7 \text { years } 8 \text { months) } \\
\text { Head, Programme on Protected Areas } \\
\text { IUCN } \\
\text { May } 1993 \text { - October } 2009 \text { (16 years } 6 \text { months) } \\
\text { CEO (Director General) } \\
\text { Secretariat of the Pacific Regional Environment Programme } \\
\text { October } 2009 \text { - Present (6 years } 2 \text { months)" } \\
\text { Prior to SPREP, David worked with IUCN, based in Switzerland, as Head of their } \\
\text { Protected Areas Programme. His roles included leading IUCN's work on protected } \\
\text { areas and on the UNESCO World Heritage Convention. He served as Secretary } \\
\text { General of the IVth IUCN World Parks Congress (WPC), held in Durban, South } \\
\text { Africa in 2003. David also worked at the Senior Executive level in the New South } \\
\text { Wales (Australia) National Parks and Wildlife Service, and worked with the } \\
\text { Tasmanian and New Zealand Governments in the forestry sector. David has also } \\
\text { worked as a consultant with the World Bank and Asian Development Bank and has } \\
\text { represented SPREP, IUCN and other organisations, at the highest level, on many } \\
\text { International Boards and Committees" (Sheppard, 2015). }\end{array}$ & \\
\hline & $\begin{array}{l}\text { 5. Executive management staff } \\
\text { disclose potential conflicts of } \\
\text { interest. }\end{array}$ & & \\
\hline & $\begin{array}{l}\text { 6. The organisation attracts, retains } \\
\text { and develops talent. }\end{array}$ & $\begin{array}{l}\text { "The Human Resources team take the lead on ensuring we recruit and retain the } \\
\text { highest quality of staff at SPREP. They look after our staff from recruitment and } \\
\text { induction through to repatriation and are also in charge of HR policies, performance } \\
\text { and professional development" (SPREP, 2014a, p. 53). }\end{array}$ & $\diamond$ \\
\hline & $\begin{array}{l}\text { 7. Leaders create a dynamic } \\
\text { organisational culture, making } \\
\text { the organisation a desirable place } \\
\text { to work. }\end{array}$ & & \\
\hline 3. Resources & $\begin{array}{l}\text { 1. There are staff members } \\
\text { exclusively dedicated to climate } \\
\text { change adaptation. }\end{array}$ & $\begin{array}{l}\text { The personnel list on the SPREP website includes an adaptation adviser and an } \\
\text { adaptation specialist, in addition to a number of adaptation project managers and } \\
\text { financial personnel (SPREP, 2014c). }\end{array}$ & V \\
\hline
\end{tabular}




\begin{tabular}{|c|c|c|c|}
\hline SUB-COMPONENT & INDICATOR & $\begin{array}{l}\text { EVIDENCE } \\
\end{array}$ & RATING \\
\hline & & $\begin{array}{l}\text { The SPREP organisational structure includes two staff and one consultant working } \\
\text { directly in climate change adaptation, along with four consultants working on the } \\
\text { "Pilot Programme for Climate Change Resilience Project" (SPREP, 2015c, p. 5). } \\
\text { "SPREP has a current staff of more than 90, with at least } 20 \text { devoted to working full } \\
\text { time on climate related issues. SPREP is a regional center [sic] of excellence and the } \\
\text { lead Pacific organization in climate change work. It has implemented over } 100 \text { donor } \\
\text { - assisted regional projects in climate change and environmental management, in } \\
\text { general, and in CCA and DRR mainstreaming, in particular" (emphasis added) } \\
\text { (SPREP, 2015a, p. 1). }\end{array}$ & \\
\hline & $\begin{array}{l}\text { 2. Staff are qualified and have } \\
\text { experience in climate change } \\
\text { adaptation. }\end{array}$ & 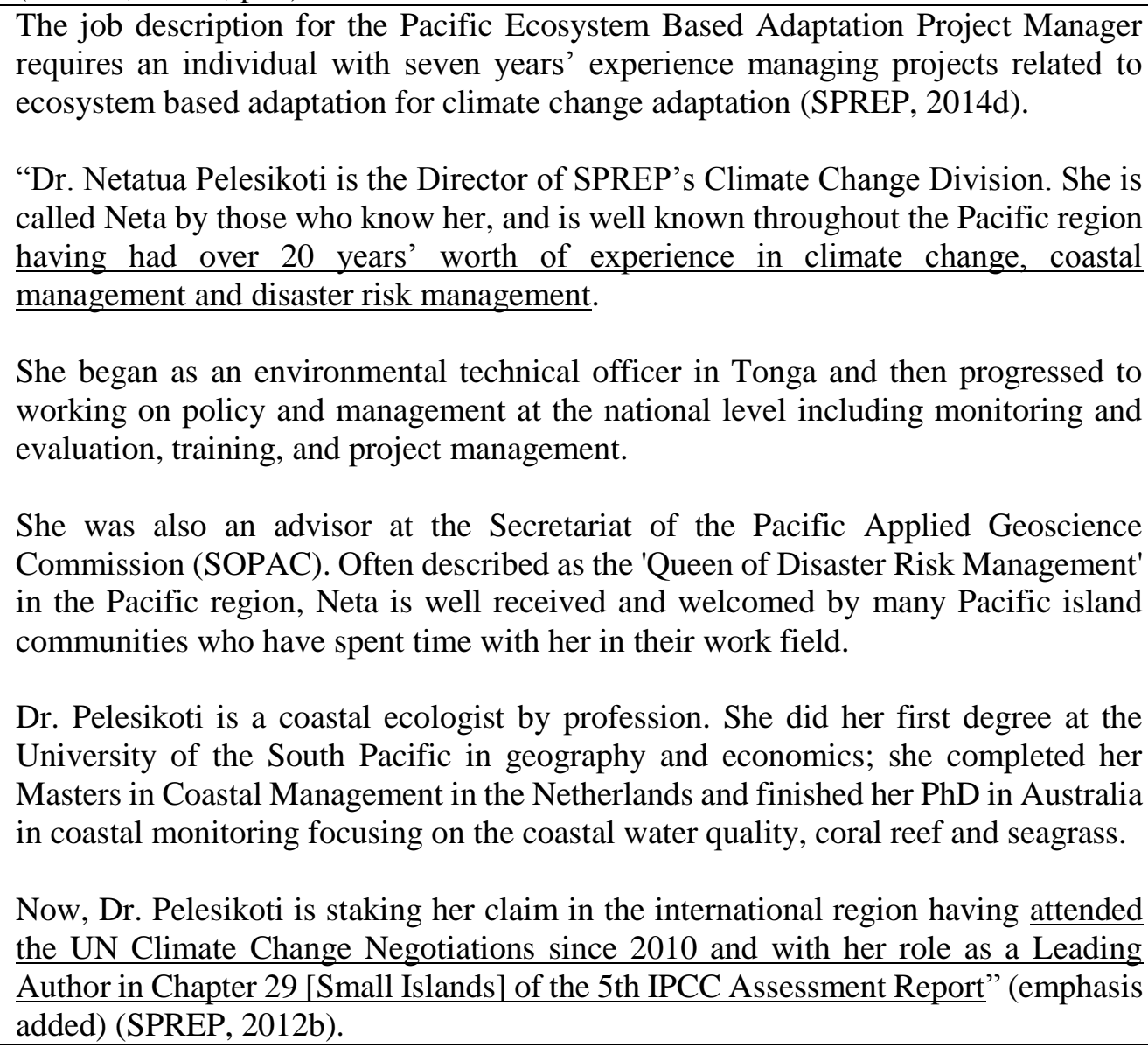 & $\nabla$ \\
\hline
\end{tabular}




\begin{tabular}{|c|c|c|c|}
\hline SUB-COMPONENT & INDICATOR & EVIDENCE & RATING \\
\hline & $\begin{array}{l}\text { 3. Staff are qualified and have } \\
\text { experience in project/program } \\
\text { management. }\end{array}$ & $\begin{array}{l}\text { The job description for the Pacific Ecosystem Based Adaptation Project Manager } \\
\text { requires an individual with seven years" experience managing projects related to } \\
\text { ecosystem based adaptation for climate change adaptation (SPREP, 2014d). } \\
\text { "For over } 10 \text { years, Paul Anderson has been working with communities, civil society, } \\
\text { national governments and regional organizations to build capacity in natural resource } \\
\text { management, climate change adaption, conservation and marine resource } \\
\text { management in the Pacific Islands and the United States. He specializes in } \\
\text { environmental monitoring, capacity building (field implementation, monitoring, } \\
\text { surveying, GIS/GPS, coastal change analysis), bilateral and multilateral } \\
\text { environmental reporting, Geographical Information Systems database management, } \\
\text { data acquisition, cartography and project management. } \\
\text { Paul had developed prioritization products for conservation sites in Pacific Islands } \\
\text { Countries and Territories, strengthened national capacity to use of latest global } \\
\text { positioning systems (GPS) as well as capacity building and resource management } \\
\text { facilitation. Developed the Pacific Islands mangrove monitoring manual. } \\
\text { He has worked with the disaster management offices in Samoa and Vanuatu and Red } \\
\text { Cross to prioritize and deliver aid after the } 2009 \text { Samoa Tsunami, Cyclone Evan in } \\
2012 \text { and Cyclone Pam in } 2014 \text {. Paul conducted the post disaster needs assessment } \\
\text { for the environment sector for the world bank after all } 3 \text { disasters" (emphasis added) } \\
\text { (Anderson, 2015). } \\
\text { "Various } \\
\text { PROJECT EXPERIENCE } \\
\text { January } 2006 \text { - Present ( } 9 \text { years } 11 \text { months) } \\
2015 \text {-current } \\
\text { Global Environment Facility Capacity Building for MEAs Project } \\
\text { Targets } 14 \text { SPREP member countries } \\
\text { Project Manager } \\
2014-2015 \\
\text { Capacity Building and Project Analysis, Civil Society Support Program, Samoa } \\
\text { Ecosystem Based Adaptation Coordinator } \\
2012-2014\end{array}$ & 曰 \\
\hline
\end{tabular}




\begin{tabular}{|c|c|c|c|}
\hline SUB-COMPONENT & INDICATOR & EVIDENCE & RATING \\
\hline & & $\begin{array}{l}\text { International Climate Change Adaptation Initiative, AusAid } \\
\text { Tonga, Samoa, Vanuatu, Kiribati } \\
\text { Development Coordinator } \\
\text { 2013-current } \\
\text { Pacific Ocean Ecosystem Analysis Project (PACIOCIA) } \\
21 \text { Pacific Island Countries and Territories (PICTs) } \\
\text { Pacific Island Hub Project Manager } \\
\text { 2012-current African Caribbean Pacific Multilateral Environmental Agreements } \\
\text { (ACPMEAs) Capacity Building Project } \\
\text { 14 PICs and Timor Leste } \\
\text { SPREP Protected Areas Observatory Adviser (BIOPAMA) } \\
\text { 2012-current Biodiversity and Protected Areas Management Programme } \\
\text { (BIOPAMA) } \\
21 \text { Pacific Island Countries and Territories (PICTs) } \\
\text { SPREP MESCAL Coordinator } \\
\text { 2010 -2012 Mangrove Ecosystems for Climate Change Adaptation \& Livelihoods } \\
\text { (MESCAL) Project } \\
\text { Fiji, Solomon Islands, Samoa, Vanuatu, Tonga } \\
\text { Marine Conservation Planning Adviser } \\
\text { 2008-2010 Biodiversity and Ecosystem Management Marine Program } \\
21 \text { Pacific Island Countries and Territories (PICTs) } \\
\text { GIS User Group Coordinator } \\
\text { 2006-2008 American Samoa Department of Commerce" (Anderson, 2015). } \\
\text { "Dr. Netatua Pelesikoti is the Director of SPREP's Climate Change Division. She is } \\
\text { called Neta by those who know her, and is well known throughout the Pacific region } \\
\text { having had over 20 years' worth of experience in climate change, coastal } \\
\text { management and disaster risk management. } \\
\text { She began as an environmental technical officer in Tonga and then progressed to } \\
\text { working on policy and management at the national level including monitoring and } \\
\text { evaluation, training, and project management. }\end{array}$ & \\
\hline
\end{tabular}




\begin{tabular}{|c|c|c|c|}
\hline SUB-COMPONENT & INDICATOR & $\begin{array}{l}\text { EVIDENCE } \\
\end{array}$ & RATING \\
\hline & & $\begin{array}{l}\text { She was also an advisor at the Secretariat of the Pacific Applied Geoscience } \\
\text { Commission (SOPAC). Often described as the 'Queen of Disaster Risk Management' } \\
\text { in the Pacific region, Neta is well received and welcomed by many Pacific island } \\
\text { communities who have spent time with her in their work field. } \\
\text { Dr. Pelesikoti is a coastal ecologist by profession. She did her first degree at the } \\
\text { University of the South Pacific in geography and economics; she completed her } \\
\text { Masters in Coastal Management in the Netherlands and finished her PhD in Australia } \\
\text { in coastal monitoring focusing on the coastal water quality, coral reef and seagrass. } \\
\text { Now, Dr. Pelesikoti is staking her claim in the international region having attended } \\
\text { the UN Climate Change Negotiations since } 2010 \text { and with her role as a Leading } \\
\text { Author in Chapter 29 [Small Islands] of the 5th IPCC Assessment Report" (emphasis } \\
\text { added) (SPREP, 2012). }\end{array}$ & \\
\hline & $\begin{array}{l}\text { 4. Staff participate in ongoing } \\
\text { training programs. }\end{array}$ & $\begin{array}{l}\text { "In 2014, SPREP continued to support continuous learning, professional } \\
\text { development and growth for all staff. In February, an off-site, learning and team- } \\
\text { building workshop for all staff under the broad theme of 'Learning Together, Leading } \\
\text { Together' was facilitated by Dr Harold Hillman and colleagues from Sigmoid Curve } \\
\text { Consulting. The programme included targeted training for senior staff and middle } \\
\text { management" (SPREP, 2014a, p. 57). } \\
\text { "During the year [2013], } 25 \text { staff members were supported under the learning and } \\
\text { development programme. This initiative is part of the Performance Development } \\
\text { System which identifies staff training and capacity building needs" (SPREP, 2013b, } \\
\text { p. 43). } \\
\text { "Led by SPREP, these [adaptation fund proposal writing] training activities were } \\
\text { supported by the Asia Pacific Adaptation Network (APAN), the Ministry of } \\
\text { Environment, Japan through their Institute for Global Environmental Strategies } \\
\text { (IGES), SPC through their European Union Global Climate Change Alliance, PIFS, } \\
\text { and UNEP through the CTCN. Additionally, in-kind support through the provision } \\
\text { of resource people was provided through the Adaptation Fund and Green Climate } \\
\text { Fund secretariats, respectively. The training helped participants to become familiar } \\
\text { with the full Adaptation Fund proposal development cycle and to respond to each of } \\
\text { the key components of the application process" (SPREP, 2014a, p. 36). }\end{array}$ & $\nabla$ \\
\hline & $\begin{array}{l}\text { 5. Staff performance is appraised } \\
\text { (formally or informally) at least } \\
\text { annually. }\end{array}$ & $\begin{array}{l}\text { "Following completion of performance reviews in early } 2014,96 \% \text { of staff had been } \\
\text { assessed as performing at or above the expected level. Four staff members received }\end{array}$ & $\square$ \\
\hline
\end{tabular}




\begin{tabular}{|c|c|c|c|}
\hline SUB-COMPONENT & INDICATOR & $\begin{array}{l}\text { EVIDENCE } \\
\end{array}$ & RATING \\
\hline & & $\begin{array}{l}\text { the Director General's Excellence Award in recognition of their exemplary and } \\
\text { exceptional performance" (SPREP, 2014a, p. 57). } \\
\text { "In 2013, SPREP established the Director General's Excellence Award to recognise } \\
\text { exemplary and exceptional performance by staff. In March, three members of staff } \\
\text { were recipients of this inaugural award" (SPREP, 2013b, p. 43). }\end{array}$ & \\
\hline & $\begin{array}{l}\text { 6. The organisation has untied } \\
\text { funding. }\end{array}$ & $\begin{array}{l}\text { SPREP is heavily reliant on project-based funding (Hay et al., 2014, p. iii). At the } \\
\text { same time, SPREP's dependence on project-based funding has been decreasing (Hay } \\
\text { et al., 2014, p. 24) }\end{array}$ & $\diamond$ \\
\hline & $\begin{array}{l}\text { 7. The organisation has funds } \\
\text { exclusively dedicated to climate } \\
\text { change adaptation. }\end{array}$ & $\begin{array}{l}\text { The report for the } 25^{\text {th }} \text { SPREP Meeting notes that SRPEP is now an accredited } \\
\text { 'Regional Implementation Entity (RIE)' for the Adaptation Fund established under } \\
\text { the Kyoto Protocol and that this accreditation would improve "SPREP's ability to } \\
\text { assist countries in developing and submitting climate change adaptation proposals for } \\
\text { funding consideration by the AF" (SPREP, 2014e, p. 6). } \\
\text { SPREP's Climate Change Division assists members to develop their capacity to } \\
\text { respond to climate change, and over the period 2011-2013 this Division is allocated } \\
55 \% \text { of SPREP's technical budget (Hay et al., 2014, p. } 8 \text { \& 27). } \\
2012 \text { Work Plan and Budget shows dedicated funding for "implementing adaptation } \\
\text { measures" (SPREP, 2011d, p. } 10 \text { ). }\end{array}$ & $\nabla$ \\
\hline & $\begin{array}{l}\text { 8. External funding to the } \\
\text { organisation has increased over } \\
\text { the past } 5 \text { years. }\end{array}$ & $\begin{array}{l}\text { Donor contributions in } 2011 \text { totalled US\$10,647,044 (SPREP, 2012a, p. 44). } \\
\text { Donor contributions in } 2014 \text { totalled US } \$ 15,817,618 \text { (SPREP, 2014a, p. 58). } \\
\text { *General trend is an increase but there has been fluctuations in contributions-2013 } \\
\text { figures were higher than } 2014 *\end{array}$ & $\nabla$ \\
\hline & $\begin{array}{l}\text { 9. The organisation has multiple } \\
\text { funding sources. }\end{array}$ & $\begin{array}{l}\text { SRPEP's } 2011 \text { Annual Report details around } \$ 880,000 \text { in member contributions from } \\
19 \text { members, and around } \$ 10,647,000 \text { from } 34 \text { donors (SPREP, 2012a, p. } 44 \text { ). }\end{array}$ & $\square$ \\
\hline & $\begin{array}{l}\text { 10. The organisation has financial } \\
\text { reserves. }\end{array}$ & $\begin{array}{l}\text { On the } 1^{\text {st }} \text { January } 2014 \text { SPREP's balance of funds was US } \$ 5,737,925 \text {, and on the } \\
31^{\text {st }} \text { December } 2014 \text { it was US } \$ 4,735,411 \text {. During the year SPREP received } \\
\text { US } \$ 15,817,618 \text { in donor contributions (SPREP, 2014a, p. 58). } \\
\text { SPREP's } 2014 \text { audited annual accounts show the following: } \\
\text { (see overleaf) }\end{array}$ & 凶 \\
\hline
\end{tabular}




\begin{tabular}{|c|c|c|c|c|c|}
\hline SUB-COMPONENT & INDICATOR & \multicolumn{3}{|c|}{ EVIDENCE } & RATING \\
\hline & & \begin{tabular}{|l|} 
Type \\
General Reserve \\
Specific Funds \\
Core Funds \\
Total Reserves \\
(SPREP, 2015g, p \\
\\
The management \\
organisation as a \\
services and that, \\
mainly to the high \\
translations (over \\
number of unexpe \\
long running issuc \\
Group (which will \\
staff. There is also \\
and cost recovery \\
membership contr
\end{tabular} & \begin{tabular}{|c|} 
31 Dec 2014 \\
$\$ 501,425$ \\
$\$ 244,452$ \\
$(\$ 1,238,598)$ \\
$\mathbf{( \$ 4 9 2 , 6 3 1 )}$ \\
\\
ment with rega \\
ole there was \\
e deficit in rel \\
sts of the revie \\
Ok), 24th SPRE \\
medical fees \\
r SPREP and i \\
et again on 17tl \\
nternal working \\
echanisms as \\
ions" (SPREP,
\end{tabular} & $\begin{array}{l}\text { 31 Dec 2013 } \\
\$ 501,425 \\
\$ 35,133 \\
(\$ 469,110) \\
\$ 67,448 \\
\text { d to the depletion of reserves was that for the } \\
\text { o deficit, that this related only to corporate } \\
\text { tion to core budget services in } 2014 \text { was due } \\
\text { s (in total over } \$ 400 \mathrm{k}), \text { the high costs of the } \\
\text { Meeting costs } \$ 255) \text { [sic?], and the cost of a } \\
\text { 2014. The issue of core funding has been a } \\
\text { being addressed by a Membership Working } \\
\text { July) comprising of Members and Secretariat } \\
\text { group addressing the issue of programme fees } \\
\text { her income for the core budget apart from } \\
015 \mathrm{~g}, \text { p. } 29) \text {. }\end{array}$ & \\
\hline & $\begin{array}{l}\text { 11. The organisation has sufficient } \\
\text { technological resources (e.g. } \\
\text { intellectual property rights, } \\
\text { patents, copyright, software } \\
\text { licences etc.) to carry out its } \\
\text { climate change adaptation } \\
\text { mandate. }\end{array}$ & & & & \\
\hline $\begin{array}{l}\text { 4. Structure, systems and } \\
\text { processes }\end{array}$ & $\begin{array}{l}\text { 1. There is a low degree of hierarchy } \\
\text { (i.e. few hierarchical levels). }\end{array}$ & & & & \\
\hline & $\begin{array}{l}\text { 2. The organisation has a human } \\
\text { resource management system that } \\
\text { supports the shaping of } \\
\text { organisational culture and staff } \\
\text { recruitment, training, } \\
\text { development and retention. }\end{array}$ & & & & \\
\hline & $\begin{array}{l}\text { 3. There is a financial management } \\
\text { system that meets International }\end{array}$ & $\begin{array}{l}\text { "In accordance wi } \\
\text { an unqualified aud } \\
\text { high standards of } f\end{array}$ & $\begin{array}{l}\text { nternational Fir } \\
\text { as undertaken } \\
\text { hcial manageme }\end{array}$ & $\begin{array}{l}\text { ancial Reporting Standards and best practice, } \\
\text { f } 2014 \text { financial statements, a testament to our } \\
\text { nt" (SPREP, 2014a, p.56). }\end{array}$ & $\nabla$ \\
\hline
\end{tabular}




\begin{tabular}{|c|c|c|c|}
\hline SUB-COMPONENT & INDICATOR & EVIDENCE & RATING \\
\hline & $\begin{array}{l}\text { Financial Reporting Standards } \\
\text { (IFRS) or its equivalent. }\end{array}$ & $\begin{array}{l}\text { *There is evidence that the audit was conducted } \rightarrow \text { published as part of } 2014 \text { Annual } \\
\text { Report* }\end{array}$ & \\
\hline & $\begin{array}{l}\text { 4. The organisation applies risk } \\
\text { management principles in its } \\
\text { decision-making processes. }\end{array}$ & $\begin{array}{l}\text { "The Secretariat will work with Members to develop annual progress reports that will } \\
\text { contribute to a mid-term consultative review in 2013. Such reports will be drawn on } \\
\text { again when the Plan is updated or replaced in 2015, and a risk management } \\
\text { framework will be applied to the Plan" (SPREP, 2011b, p. 6). }\end{array}$ & \\
\hline & $\begin{array}{l}\text { 5. The organisation has a } \\
\text { centralised, user-friendly internal } \\
\text { data management system. }\end{array}$ & & \\
\hline & $\begin{array}{l}\text { 6. The organisation has a user- } \\
\text { friendly project/program } \\
\text { management system (e.g. that } \\
\text { supports staff to identify, } \\
\text { schedule and track resources } \\
\text { etc.). }\end{array}$ & & \\
\hline & $\begin{array}{l}\text { 7. There are mechanisms that } \\
\text { support vertical and horizontal } \\
\text { communication. }\end{array}$ & & \\
\hline & $\begin{array}{l}\text { 8. There are internal dispute } \\
\text { resolution protocols. }\end{array}$ & & \\
\hline $\begin{array}{l}\text { 5. } \begin{array}{l}\text { Research and } \\
\text { collaboration } \\
\text { capacity }\end{array} \\
\end{array}$ & $\begin{array}{l}\text { 1. The organisation has plans and } \\
\text { policies that support research. }\end{array}$ & $\begin{array}{l}\text { SPREP's action plan "promoting and developing programmes, including research } \\
\text { programmes, to protect the atmosphere and terrestrial, freshwater, coastal and marine } \\
\text { ecosystems and species, while ensuring ecologically sustainable utilisation of } \\
\text { resources" (SPREP, 1993, Article 2.2.c). }\end{array}$ & $\nabla$ \\
\hline & $\begin{array}{l}\text { 2. There are organisational funds } \\
\text { allocated for research. }\end{array}$ & $\begin{array}{l}\text { The Climate Change Strategy aims to "Enhance and build capacity for conducting } \\
\text { applied research, fostering meteorological, climatological and oceanic observation } \\
\text { and monitoring programmes to improve understanding, awareness, and applications } \\
\text { of targeted responses to climate change and related disaster risk reduction". } \\
\$ 1,104,000 \text { has been allocated/estimated for this activity(SPREP, 2011d, pp. 12-13). } \\
\text { SPREP's } 2014 \text { Work Programme and Approved Budget has listed as a climate } \\
\text { change goal, "C1.2.1c: Adequate regional meteorological and oceanographic services } \\
\text { are provided to ensure access to quality and timely weather and ocean state } \\
\text { information" (emphasis added) (SPREP, 2013c, pp. 16-17), with US } \$ 458,596 \\
\text { allocated towards achieving the goal. }\end{array}$ & $\nabla$ \\
\hline
\end{tabular}




\begin{tabular}{|c|c|c|c|}
\hline SUB-COMPONENT & INDICATOR & EVIDENCE & RATING \\
\hline & & $\begin{array}{l}\text { Two of the } 2014 \text { activities associated with this goal are: } \\
\text { "6. PMDP [Pacific Meteorological Desk Partnership] preparing at least one regional } \\
\text { pre-COP briefing paper for SPREP UNFCCC preparations for PICs } \\
\text { 7. PMDP assisting efforts on climate change projection work in-country" (emphasis } \\
\text { added) (SPREP, 2013c, p. 17). } \\
\text { SPREP's } 2014 \text { Work Programme and Approved Budget includes US } \$ 99,587 \text { for the } \\
\text { PI- Global Ocean Observing System Coordinator, (PI-GOOS). In the Pacific, PI- } \\
\text { GOOS is designed "to assist sustainable development by facilitating the } \\
\text { establishment and implementation of coastal and open ocean observing programmes, } \\
\text { and in helping to improve uptake and use of the data, information and products being } \\
\text { generated. Implementation of the PI-GOOS programme is primarily through capacity } \\
\text { building at the local and regional level, and via the delivery of useful observation } \\
\text { related products to relevant national level Government departments and other } \\
\text { national partners" (SPREP, 2011c, p. 4). } \\
\text { "The position of Pacific Islands - Global Ocean Observing System Coordinator } \\
\text { (PIGOOSC) addresses the following Key Result Areas: } \\
\text { - Development and management of the GOOS programme } \\
\text { - Facilitation of the PIGOOS Advisory Committee } \\
\text { - Capacity building programmes Advisory and reporting } \\
\text { - Publication" (SPREP, 2011c, p. 6). } \\
\text { "Following the untimely passing of Mr Lui Bell in } 2012 \text {, who was working at the } \\
\text { time as SPREP's Marine Species Adviser, a scholarship fund was established by } \\
\text { SPREP to honour his memory. Through the fund, a grant of up to USD } 20,000 \text { is } \\
\text { awarded to assist a young person from the Pacific to undertake a course of post- } \\
\text { graduate study that will contribute to those issues about which Lui was most } \\
\text { passionate - the conservation of the threatened and migratory species of the Pacific } \\
\text { islands" (SPREP, 2014a, p. } 22 \text { ). } \\
\text { In } 2014 \text {, the Secretariat's publishing function oversaw a significant increase in the } \\
\text { number of publications produced. In the period from January - December } 2014 \text {. }\end{array}$ & \\
\hline
\end{tabular}




\begin{tabular}{|c|c|c|c|}
\hline \multirow[t]{4}{*}{ SUB-COMPONENT } & INDICATOR & EVIDENCE & RATING \\
\hline & & $\begin{array}{l}\text { SPREP produced } 50 \text { new publications, not including meeting reports or promotional } \\
\text { materials" (SPREP, 2014a, p. 55). }\end{array}$ & \\
\hline & $\begin{array}{l}\text { 3. The organisation has equipment, } \\
\text { expertise and/or resources (e.g. } \\
\text { access to journal articles etc.) for } \\
\text { research. }\end{array}$ & $\begin{array}{l}\text { In March } 2010 \text { four elements of SOPAC (The Pacific Islands Applied Geoscience } \\
\text { Commission) were transferred to SPREP (SPREP and SOPAC, 2010). One of the } \\
\text { elements transferred was The Pacific Islands Global Ocean Observing System (PI- } \\
\text { GOOS), which monitors the Pacific Ocean using "a range of environmental sensors, } \\
\text { from satellites which can monitor the sea surface from high in space, to teams of } \\
\text { people who monitor coral reef health while diving and snorkelling, and even to highly } \\
\text { sophisticated robots which sink into the ocean depth before climbing back to the } \\
\text { surface every } 10 \text { days" (emphasis added) (SPREP, 2015f). }\end{array}$ & $\nabla$ \\
\hline & $\begin{array}{l}\text { 4. The organisation's current } \\
\text { strategic plan (or a similar } \\
\text { document) outlines plans for } \\
\text { collaboration with multiple } \\
\text { stakeholders on adaptation- } \\
\text { related initiatives. }\end{array}$ & $\begin{array}{l}\text { "For the Secretariat it [achieving the } 2015 \text { targets and outcomes] means delivering } \\
\text { quality service to Members by expanding the funding base of the organisation, } \\
\text { implementing responsive change management to ensure that programmes are } \\
\text { relevant and viable, and working in partnership with other organisations and } \\
\text { stakeholders that support SPREP's strategic priorities" (emphasis added) (SPREP, } \\
\text { 2011b, p. 2). } \\
\text { PIFACC document recognises the limited technical resources and the need to } \\
\text { collaborate. } \\
\text { Expected outcomes in Framework document. }\end{array}$ & $\square$ \\
\hline \multicolumn{4}{|c|}{ 2. Project/Program Effectiveness - PACC } \\
\hline \multirow[t]{2}{*}{ 1. Needs and goals } & $\begin{array}{l}\text { 1. The project documents contain } \\
\text { evidence that the project/program } \\
\text { fills an existing need with relation } \\
\text { to climate change adaptation. }\end{array}$ & $\begin{array}{l}\text { "Prior to the PACC programme, efforts to try and reduce vulnerability were } \\
\text { piecemeal and were not seen to be contributing to an overall strengthening of adaptive } \\
\text { capacity across the region. Business-as-usual development did not integrate climate } \\
\text { change adaptation at national (state) or community (municipal) level planning, } \\
\text { resulting in infrastructure being easily damaged by climate variability and extreme } \\
\text { events. The PACC programme was developed to lay the groundwork for a more } \\
\text { coordinated and integrated approach to ensure that vulnerabilities are reduced and } \\
\text { that development activities achieve their social, economic and ecological goals. The } \\
\text { programme addresses Pacific island priority actions for climate change adaptation } \\
\text { by: (1) demonstrating practical 'on the ground' measures; (2) promoting climate- } \\
\text { sensitive national policy; (3) strengthening community or municipality coping } \\
\text { capacity; and (4) building resilience at the level of national and state economies" } \\
\text { (SPREP, 2013a, p. 3). }\end{array}$ & $\square$ \\
\hline & $\begin{array}{l}\text { 2. The project/program's adaptation } \\
\text { components could be considered } \\
\text { 'transformational' } \quad \text { (i.e. the }\end{array}$ & $\begin{array}{l}\text { "The MTR [PACC Mid Term Review] considers it important to understand what } \\
\text { 'baseline assessment' means. If the current 'development baseline' is used, with } \\
\text { adaptation funding covering 'additionality', then the implicit assumption being made }\end{array}$ & \\
\hline
\end{tabular}




\begin{tabular}{|c|c|c|c|}
\hline SUB-COMPONENT & INDICATOR & EVIDENCE & RATING \\
\hline & & $\begin{array}{l}\text { "Mainstreaming efforts are also beginning to reap rewards, as countries move } \\
\text { towards integrating climate into their policies and planning" (SPREP, 2013a, p. 2). } \\
\text { "One aim of the PACC project is to lay foundations for successful adaptation in the } \\
\text { region" (SPREP, 2013a, p. 37). }\end{array}$ & \\
\hline & $\begin{array}{l}\text { 5. The project/program's objectives } \\
\text { relating to climate change } \\
\text { adaptation are specific, } \\
\text { measurable, achievable, realistic } \\
\text { and time-bound (SMART). }\end{array}$ & $\begin{array}{l}\text { Example: "By the end of the project, the National coastal, crop production and water } \\
\text { sector Management Plan, Sustainable Development Plan, National Risk Management } \\
\text { Plan, and at least two (2) Provincial /Risk management Plans include climate change } \\
\text { risk and adaptation measures for the coastal, crop production and water sector in all } \\
13 \text { PACC countries" (emphasis added) (UNDP and SPREP, 2008, p. 87). }\end{array}$ & $\diamond$ \\
\hline & $\begin{array}{l}\text { 6. Member Countries were involved } \\
\text { in developing the climate change } \\
\text { adaptation components of the } \\
\text { project/program. }\end{array}$ & $\begin{array}{l}\text { "The National Climate Change Teams or National Advisory Committee on Climate } \\
\text { Change already exists within each of the participating countries. In the PDBB [???] } \\
\text { Phase of PACC, the NCCCT [National Climate Change Country Team] have been } \\
\text { used to determine the priorities for adaptation implementation within each country. } \\
\text { However, given that PACC is focused on implementing adaptation activities in pilot } \\
\text { sites of each country it will be important for the membership to include: } \\
\text { - Representatives of civil society organisations and relevant NGOs, particularly } \\
\text { working within communities where the project is set; } \\
\text { - Representatives of island/community/village, local-level, and provincial } \\
\text { Governments" (UNDP and SPREP, 2008, p. 112) }\end{array}$ & $\square$ \\
\hline 2. Scope & $\begin{array}{l}\text { 1. The project/program addresses } \\
\text { multiple climate or climate- } \\
\text { induced vulnerabilities (e.g. } \\
\text { vulnerability to sea-level rise, } \\
\text { increased sea surface and air } \\
\text { temperature, changing rainfall } \\
\text { patterns etc.). }\end{array}$ & $\begin{array}{l}\text { "The three outcomes that the project is striving to achieve are: } \\
\text { - Policy changes to deliver immediate vulnerability-reduction benefits in the } \\
\text { context of emerging climate risks are defined in all PACC countries } \\
\text { ('mainstreaming'). } \\
\text { - Demonstration measures to reduce vulnerability in coastal areas (Cook Islands, } \\
\text { Federated States of Micronesia, Samoa and Vanuatu), food production (Fiji, } \\
\text { Papua New Guinea, Palau and Solomon Islands) and water management (in } \\
\text { Marshall Islands, Nauru, Niue, Tonga, Tokelau and Tuvalu) are implemented in } \\
\text { selected communities ('demonstrations'). } \\
\text { - Capacity to plan for and respond to changes in climate-related risks are improved } \\
\text { ('knowledge')" (SPREP, 2013a, p. 4). } \\
\text { "Sea level rise alone, with no changes in climate variability, would increase the risk } \\
\text { of flooding and inundation on the low-lying atolls. However, in recent years changes }\end{array}$ & $\square$ \\
\hline
\end{tabular}




\begin{tabular}{|c|c|c|c|}
\hline SUB-COMPONENT & INDICATOR & $\begin{array}{c}\text { EVIDENCE } \\
\end{array}$ & RATING \\
\hline & & $\begin{array}{l}\text { in climate variability in Ontong Java have been observed. Dry seasons have expanded } \\
\text { into wet seasons, as experienced in the } 2011 \text { El Niño and La Niña events. An increase } \\
\text { in the frequency and intensity of extreme rainfall events is likely to create flooding } \\
\text { and waterlogging problems. Waterlogging would impact on crops, for example sweet } \\
\text { potato tuber formation. Despite the projection that the incidence of drought will } \\
\text { decrease, the influence of the ENSO cycle on the occurrence of severe drought must } \\
\text { be acknowledged" (SPREP, 2015d, p. 5). }\end{array}$ & \\
\hline & $\begin{array}{l}\text { 2. The project/program addresses } \\
\text { multiple non-climate-induced } \\
\text { vulnerabilities (e.g. poverty, } \\
\text { deforestation etc.). }\end{array}$ & $\begin{array}{l}\text { "At the national and community level, the demonstration measures will contribute to } \\
\text { building the resilience of communities to climate related risks, improving livelihoods } \\
\text { and alleviating poverty, which is a key priority for national governments" (UNDP } \\
\text { and SPREP, 2008, p. 27). } \\
\text { Project addresses population growth, limited sources of income and low soil fertility } \\
\text { (SPREP, 2015d, p. 5). }\end{array}$ & $\square$ \\
\hline \multirow[t]{2}{*}{$\begin{array}{l}\text { 3. Logic, design and } \\
\text { adequacy }\end{array}$} & $\begin{array}{l}\text { 1. The logic/design of the } \\
\text { project/program's climate change } \\
\text { adaptation components is } \\
\text { evidence-based, in the context of } \\
\text { SIDS. }\end{array}$ & $\begin{array}{l}\text { "Pacific island countries are already experiencing the impacts of climate change. The } \\
\text { potential magnitude of the problem threatens the very existence of some Pacific } \\
\text { island states, and the achievement of sustainable development and Millennium } \\
\text { Development Goals. However, vulnerabilities and risks associated with climate } \\
\text { change are not currently being addressed in any systematic way. Climate change risks } \\
\text { and opportunities are not reflected in national and community level planning and } \\
\text { governance processes. Individual, institutional and systemic capacity is not targeted } \\
\text { towards strategic interventions. Demonstrations of adaptation pilots in key } \\
\text { development sectors have not been implemented, and as a consequence few are } \\
\text { replicated and scaled-up. The PACC Project aims to significantly improve the } \\
\text { effectiveness of the response to climate change in the Pacific. The project will } \\
\text { improve technical capacities to support appropriate adaptation centric policies, } \\
\text { demonstrate cost-effective adaptation techniques in key sectors, and promote } \\
\text { regional cooperation. It is designed to lay the framework for effective and efficient } \\
\text { future investment on climate change adaptation in the Pacific" (UNDP and SPREP, } \\
\text { 2008, p. 1). }\end{array}$ & $\square$ \\
\hline & $\begin{array}{l}\text { 2. The project documents contain } \\
\text { evidence that the logic/design of } \\
\text { the project/program's climate } \\
\text { change adaptation components is } \\
\text { an effective means to achieve its } \\
\text { objectives. }\end{array}$ & $\begin{array}{l}\text { Effectiveness ratings in PACC Demonstration Guide } \rightarrow \text { Introduce new farming } \\
\text { systems, suitable salt resistant crops=Medium; CC awareness=Low; environment } \\
\text { and resource management training for community=Medium; relocation plan=Low } \rightarrow \\
\text { no discussion of effectiveness ratings (SPREP, 2015d, p. 14). } \\
\\
\text { The MTR notes that results "have been mixed; some of the individual exercises have } \\
\text { been organised and completed thoroughly, and have produced interesting findings. } \\
\text { The CBA work stands out in this regard. Other support exercises and training have }\end{array}$ & $\diamond$ \\
\hline
\end{tabular}




\begin{tabular}{|c|c|c|c|}
\hline SUB-COMPONENT & INDICATOR & $\begin{array}{l}\text { EVIDENCE } \\
\end{array}$ & RATING \\
\hline & & $\begin{array}{l}\text { not worked well; guides produced have not been useful or applicable in the PACC } \\
\text { countries. The MTR considers that overall the regional support work has been only } \\
\text { marginally satisfactory; it has not been efficient or cost-effective in enabling the } \\
\text { country projects to produce better results. The support work program should have } \\
\text { been less ambitious, which would have helped to improve the RPMU's efficiency of } \\
\text { delivery. It is not useful for example, to be developing and introducing new guidance } \\
\text { materials (Mainstreaming, CBA) in the fourth year of a 5-year project. Throughout } \\
\text { the project the sequence of the support work has been poorly scheduled, and has not } \\
\text { been provided on demand or in a useful timeframe for the country project teams. The } \\
\text { MTR considers that the particular problem has been the lack of an overall coherent } \\
\text { strategy for the support helped to improve the RPMU's efficiency of delivery. It is } \\
\text { not useful for example, to be developing and introducing new guidance materials } \\
\text { (Mainstreaming, CBA) in the fourth year of a } 5 \text { - year project. Throughout the project } \\
\text { the sequence of the support work has been poorly scheduled, and has not been } \\
\text { provided on demand or in a useful timeframe for the country project teams. The MTR } \\
\text { considers that the particular problem has been the lack of an overall coherent strategy } \\
\text { for the support work; it has not been aligned to a planning framework at country or } \\
\text { regional levels. Tools have been applied out of sequence, without a clear } \\
\text { understanding of what they are supposed to be achieving, and in some cases are } \\
\text { inappropriate to the context. Underlying these issue s is a lack of focus on the core } \\
\text { concern of climate adaptation and resilience" (Hunnam et al., 2012, pp. 10-11). }\end{array}$ & \\
\hline \multirow[t]{2}{*}{ 4. Resources } & $\begin{array}{l}\text { 1. Staff members } \\
\text { exclusively }\end{array}$ are $\begin{array}{r}\text { assigned } \\
\text { project/program. }\end{array}$ & $\begin{array}{l}\text { "A full-time Regional Project Manager (RPM) for PACC will be, funded by the } \\
\text { project and based as a contracted staff member at SPREP" (UNDP and SPREP, 2008, } \\
\text { p. 67). } \\
\text { *RPM Taito Nakalevu hired; resigned in February } 2014 \text { (SPREP, 2014b). }\end{array}$ & $\square$ \\
\hline & $\begin{array}{l}\text { 2. The project/program team } \\
\text { includes staff members with } \\
\text { qualifications and experience in } \\
\text { climate change adaptation. }\end{array}$ & $\begin{array}{l}\text { "The PMO will be established and located in SPREP as part of its Pacific Futures } \\
\text { Programme will be responsible for the overall project operation and financial } \\
\text { management .... Regional and international experts will be contracted to support the } \\
\text { PMO as and when needed to undertake various project activities" (UNDP and } \\
\text { SPREP, 2008, p. 67). } \\
\text { "The RPM [Regional Project Manager] shall have the following basic required } \\
\text { qualifications and expertise: } \\
\text { - Advanced university degree (at least MSc. or equivalent) in geography, } \\
\text { environmental science or other field relevant to the project; }\end{array}$ & $\diamond$ \\
\hline
\end{tabular}




\begin{tabular}{|c|c|c|c|}
\hline SUB-COMPONENT & INDICATOR & $\begin{array}{l}\text { EVIDENCE } \\
\end{array}$ & RATING \\
\hline & & $\begin{array}{l}\text { - Extensive knowledge and experience with the climate change, adaptation and } \\
\text { development issues of the PICs; } \\
\text { - Proven track record of technical and managerial experience of an adaptation } \\
\text { implementation project;" (UNDP and SPREP, 2008, pp. 102-3). } \\
\text { "Taito Nakalevu is the Project Manager for the Pacific Adaptation to Climate Change } \\
\text { Project. Originally from Fiji, he obtained his Bachelor and Master of Arts Degrees } \\
\text { from the University of the South Pacific, Fiji. Taito started his career as a high school } \\
\text { teacher in Fiji and moved on to a European Union funded Programme called the } \\
\text { 'Pacific Regional Agriculture Programme' (PRAP) as a Graduate Research Assistant, } \\
\text { a project that was executed by the University of the South Pacific and later, the } \\
\text { Secretariat of the Pacific Community (SPC). In this position, he worked very closely } \\
\text { with the Fiji-German Forestry and Agroforestry Project carrying out agroforestry } \\
\text { research in the hinterlands of Fiji. In 1999, he joined the Ministry of Agriculture, } \\
\text { Land Resource Planning and ALTA as Senior Research Officer, Land Use Planning, } \\
\text { for the Central/Eastern Division" (Nakavelu, 2015). } \\
\text { There is a gap in Taito Nakavelu's history, however in December 2005 he was } \\
\text { working for SPREP as a climate change adaptation officer (UNEP, 2005), and } \\
\text { appears to have worked in climate change adaptation since then. }\end{array}$ & \\
\hline & $\begin{array}{l}\text { 3. The project/program team } \\
\text { includes staff members with } \\
\text { qualifications and experience in } \\
\text { project/program management. }\end{array}$ & $\begin{array}{l}\text { "Regional and international experts will be contracted to support the PMO as and } \\
\text { when needed to undertake various project activities" (UNDP and SPREP, 2008, p. } \\
\text { 67). } \\
\text { "The RPM [Regional Project Manager] shall have the following basic required } \\
\text { qualifications and expertise: } \\
\text { - Proven track-record of management experience with GEF- and UNDP-funded } \\
\text { projects or similar regional/multi-country projects in small island developing } \\
\text { countries; } \\
\text { - Demonstrated experience in project leadership and management; } \\
\text { - Ability to manage the work of consultants/sub-contractors } \\
\text { - Proven ability to work as part of an interdisciplinary and/or multi-cultural team } \\
\text { - isility to meet project deadlines; and an ability to live and work within Pacific } \\
\text { - Minimum of } 5 \text { years of working experience in the area relevant to the project" } \\
\text { (UNDP and SPREP, 2008, pp. 102-3). }\end{array}$ & $\diamond$ \\
\hline
\end{tabular}




\begin{tabular}{|c|c|c|c|}
\hline SUB-COMPONENT & INDICATOR & EVIDENCE & RATING \\
\hline & & $\begin{array}{l}\text { "Taito Nakalevu is the Project Manager for the Pacific Adaptation to Climate Change } \\
\text { Project. Originally from Fiji, he obtained his Bachelor and Master of Arts Degrees } \\
\text { from the University of the South Pacific, Fiji. Taito started his career as a high school } \\
\text { teacher in Fiji and moved on to a European Union funded Programme called the } \\
\text { 'Pacific Regional Agriculture Programme' (PRAP) as a Graduate Research Assistant, } \\
\text { a project that was executed by the University of the South Pacific and later, the } \\
\text { Secretariat of the Pacific Community (SPC). In this position, he worked very closely } \\
\text { with the Fiji-German Forestry and Agroforestry Project carrying out agroforestry } \\
\text { research in the hinterlands of Fiji. In 1999, he joined the Ministry of Agriculture, } \\
\text { Land Resource Planning and ALTA as Senior Research Officer, Land Use Planning, } \\
\text { for the Central/Eastern Division" (Nakavelu, 2015). } \\
\text { There is a gap in Taito Nakavelu's history, however in December 2005 he was } \\
\text { working for SPREP as a climate change adaptation officer (UNEP, 2005). } \\
\text { Peniamina Leavai works "for a regional organization (SPREP) in the Pacific region, } \\
\text { as an Adaptation Planning Officer for the Pacific Adaptation to Climate Change } \\
\text { (PACC) Project. His expertise is on more than ten years of experience in climate } \\
\text { change adaptation in Samoa and the pacific region. With emphasis on water resource } \\
\text { management, integrated coastal zone management, food security \& food production; } \\
\text { and emerging issues of climate change and gender, and cc and human rights. Mr. } \\
\text { Leavai's background is on environmental science, earth science, Pacific Island } \\
\text { geography and geology, environmental management and sustainable development. } \\
\text { BSc (USP, Fiji), MSc (Tongji-IESD UNEP, Shanghai China), PRINCE2 } \\
\text { Foundation" (emphasis added) (Leavai, 2015). }\end{array}$ & \\
\hline & $\begin{array}{l}\text { The project documents contain } \\
\text { evidence that there are sufficient } \\
\text { staff members to achieve the } \\
\text { project/program objectives. }\end{array}$ & & \\
\hline & $\begin{array}{l}\text { 5. The project documents contain } \\
\text { evidence that there is sufficient } \\
\text { funding for the project/program's } \\
\text { climate change adaptation } \\
\text { components. }\end{array}$ & $\begin{array}{l}\text { The PACC project was intended to run from } 2008 \text { to } 2012 \text {, however implementation } \\
\text { did not begin until } 2009 \text { and the end date was shifted to 2013, and then to } 2014 \text {. } \\
\text { Additional funding for the project was made available in mid-2011 (Hunnam et al., } \\
\text { 2012). }\end{array}$ & $\mathbf{x}$ \\
\hline $\begin{array}{l}\text { 5. Technical } \\
\text { efficiency }\end{array}$ & $\begin{array}{l}\text { 1. The project documents contain } \\
\text { evidence that the project/program }\end{array}$ & $\begin{array}{l}\text { "The MTR [PACC Mid Term Review] considers that overall the regional support } \\
\text { work has been only marginally satisfactory; it has not been efficient or cost - effective }\end{array}$ & 曰 \\
\hline
\end{tabular}




\begin{tabular}{|c|c|c|c|}
\hline SUB-COMPONENT & INDICATOR & $\begin{array}{l}\text { EVIDENCE } \\
\end{array}$ & RATING \\
\hline & $\begin{array}{l}\text { provides value for money (cost } \\
\text { vs. outputs). }\end{array}$ & $\begin{array}{l}\text { in enabling the country projects to produce better results" (emphasis added) (Hunnam } \\
\text { et al., 2012, p. 10). }\end{array}$ & \\
\hline 6. Implementation & $\begin{array}{l}\text { 1. The project/program's climate } \\
\text { change adaptation components } \\
\text { are implemented, as proposed. }\end{array}$ & $\begin{array}{l}\text { Project completion report not yet available. The mid-term report, (SPREP, 2013a), } \\
\text { shows implementation of adaptation strategies as intended. } \\
\text { Talking about some of the implementation challenges, the PACC Project Manager, } \\
\text { Taito Nakavelu said, "We've come up against lack of expertise in various areas, for } \\
\text { example with mainstreaming and in some technical fields. But we've worked through } \\
\text { on a case-by-case basis and found some good solutions. We've brought in regional } \\
\text { partners and consultants when needed, and developed guidance materials and training } \\
\text { processes tailored to country needs. In an ideal situation projects follow a cycle of } \\
\text { planning, implementation and monitoring, but because of the complex nature of the } \\
\text { PACC programme this has not been always possible. We have had to adjust and adapt } \\
\text { to make things work. But this is part of the learning process we are all going through" } \\
\text { (SPREP, 2013a, p. 39). } \\
\text { A year earlier than this statement, in the } 2012 \text { mid-term review of PACC, } \\
\text { commissioned by the UNDP, independent consultants described the project in a more } \\
\text { critical manner, "The MTR notes that results have been mixed; some of the individual } \\
\text { exercises have been organised and completed thoroughly, and have produced } \\
\text { interesting findings. The CBA work stands out in this regard. Other support exercises } \\
\text { and training have not worked well; guides produced have not been useful or } \\
\text { applicable in the PACC countries. The MTR considers that overall the regional } \\
\text { support work has been only marginally satisfactory; it has not been efficient or cost - } \\
\text { effective in enabling the country projects to produce better results" (Hunnam et al., } \\
\text { 2012, p. 10). }\end{array}$ & $\diamond$ \\
\hline $\begin{array}{l}\text { 7. Monitoring and } \\
\text { evaluation }\end{array}$ & $\begin{array}{l}\text { 1. The project/program is internally } \\
\text { monitored and evaluated. }\end{array}$ & $\begin{array}{l}\text { The PACC project documents include nine pages detailing the monitoring and } \\
\text { evaluation plan and budget. This plan is to be executed by the project team with } \\
\text { additional support (UNDP and SPREP, 2008, pp. 70-78). } \\
\text { There are published internal progress reports (eg. GEF et al., 2010). } \\
\text { "Project monitoring was difficult because of the remoteness of Ontong Java and } \\
\text { limited communications. The PACC PMU initially planned to visit every three } \\
\text { months but bad weather and changes to the shipping schedule often meant these trips } \\
\text { had to be cancelled. Therefore the PACC team nominated the lead farmer from } \\
\text { permaculture plot } 1 \text { to provide monitoring information to the PACC PMU in } \\
\text { Honiara" (SPREP, 2015d, p. 21). }\end{array}$ & $\square$ \\
\hline
\end{tabular}




\begin{tabular}{|c|c|c|c|}
\hline SUB-COMPONENT & INDICATOR & $\begin{array}{l}\text { EVIDENCE } \\
\end{array}$ & RATING \\
\hline & $\begin{array}{l}\text { 2. The project/program is externally } \\
\text { monitored and evaluated. }\end{array}$ & $\begin{array}{l}\text { The project design documents specify that the mid-term and final evaluations will be } \\
\text { conducted by independent external evaluators (UNDP and SPREP, 2008, p. 76). } \\
\text { Mid-term review conducted externally-89pp document (Hunnam et al., 2012). } \\
\text { Dr Gavin Kenny } \rightarrow \text { "I worked as part of a team of three to complete a mid-term } \\
\text { evaluation of the PACC project, under contract to UNDP. This was a very } \\
\text { challenging assignment with the size, geographic extent, and many challenges with } \\
\text { the project. My principal role was to review the project in countries that had chosen } \\
\text { an agricultural focus for PACC, which required visits to Fiji, Papua New Guinea and } \\
\text { Solomon Islands. I also contributed to evaluation of the coastal project in Samoa" } \\
\text { (Earth Limited, n.d., online). }\end{array}$ & $\nabla$ \\
\hline 8. Sustainability & $\begin{array}{l}\text { 1. There are sustained outputs from } \\
\text { the project/program. }\end{array}$ & & \\
\hline \multicolumn{4}{|c|}{ 3. Output Effectiveness } \\
\hline 1. Goal attainment & $\begin{array}{l}\text { 1. There is evidence in the most } \\
\text { recent annual report or evaluation } \\
\text { that the climate change } \\
\text { adaptation-related objectives of } \\
\text { the organisation are being } \\
\text { achieved. }\end{array}$ & $\begin{array}{l}\text { SPREP publishes annual monitoring and evaluation reports that are based on the } \\
\text { approved work plan and budget for the year and question, with this stemming from } \\
\text { the strategic plan. For example, the target, "At least } 10 \text { PICT Members have } \\
\text { mainstreamed climate change adaptation, including ecosystem based approaches, and } \\
\text { risk reduction considerations in their national sustainable development strategies } \\
\text { (NSDS) or equivalent and resources have been mobilised for their implementation" } \\
\text { appears first in SPREP's } 2011-2015 \text { strategic plan (SPREP, 2011b, p. 17), and later } \\
\text { in the } 2014 \text { Approved Work Programme and Budget (SPREP, 2013c, p. 11), with a } \\
\text { budget of US } \$ 1,022,325 \text { attached, and finally in the 2014 Performance and } \\
\text { Monitoring Evaluation Report for } 2014 \text { (SPREP, 2015e, p. 8) with an actual } \\
\text { expenditure of US } \$ 909,486 \text { and with the target } 100 \% \text { complete. } \\
\text { "CC } 1.3 .1 \text { By } 2015 \text {, there is a significant increase in resources for adaptation: more } \\
\text { funding disbursed and projects implemented" (emphasis added) (SPREP, 2015e, p. } \\
\text { 12), was } 80 \% \text { complete in December } 2014 \text {. } \\
\text { CC 2.1.2 By } 2011 \text { a climate change portal developed; at least five targeted awareness } \\
\text { programmes and communication strategies developed and delivered to raise the } \\
\text { level of awareness and facilitate information exchange for key sectors (SPREP, } \\
2015 \mathrm{e} \text {, p. 14), } 90 \% \text { complete in December } 2014 \text {. }\end{array}$ & $\diamond$ \\
\hline
\end{tabular}




\begin{tabular}{|c|c|c|c|}
\hline SUB-COMPONENT & INDICATOR & EVIDENCE & RATING \\
\hline \multirow[t]{2}{*}{$\begin{array}{l}\text { 2. Research and } \\
\text { knowledge } \\
\text { management }\end{array}$} & $\begin{array}{l}\text { 1. The organisation produces and/or } \\
\text { publishes research that is relevant } \\
\text { to climate change adaptation at } \\
\text { least annually. }\end{array}$ & $\begin{array}{l}\text { "In 2014, the Secretariat's publishing function oversaw a significant increase in the } \\
\text { number of publications produced. In the period from January - December } 2014 \text {, } \\
\text { SPREP produced } 50 \text { new publications, not including meeting reports or promotional } \\
\text { materials" (SPREP, 2014a, p. 55). E.g. PACC Demonstration Guide: Piloting climate } \\
\text { change adaptation in food production and food security on low-lying atolls of } \\
\text { Solomon Islands (PTR19) (June 2015). }\end{array}$ & 曰 \\
\hline & $\begin{array}{l}\text { 2. The organisation makes climate } \\
\text { change adaptation-relevant } \\
\text { research publicly available. }\end{array}$ & $\begin{array}{l}\text { "the number of publications produced is reflected in the bi-annual distribution of } \\
\text { resources to depository libraries around the region and abroad, with hard copy } \\
\text { distribution increasing from } 7 \text { to } 32 \text { in the twelve month period" (SPREP, 2014a, p. } \\
55 \text { ). } \\
\text { "In the Pacific region, SPREP's Pacific Climate Change Portal (PCCP) is a key } \\
\text { online hub for information related to climate change. The website is updated on a } \\
\text { daily basis, ensuring that the information it houses is always relevant and up-to-date" } \\
\text { (SPREP, 2014a, p. } 35) \text {. The PCCP is publicly available. }\end{array}$ & $\square$ \\
\hline \multirow[t]{2}{*}{$\begin{array}{l}\text { 3. Collaboration and } \\
\text { advocacy }\end{array}$} & $\begin{array}{l}\text { 1. There is evidence that the } \\
\text { organisation collaborates with } \\
\text { multiple stakeholders to } \\
\text { undertake climate change } \\
\text { adaptation-related activities. }\end{array}$ & $\begin{array}{l}\text { "The PCCR [SPREP led Pacific Climate Change Roundtable] coordinates climate } \\
\text { change dialogue and networking in the region and facilitates links between global, } \\
\text { regional, national and community stakeholders. This coordination role directly } \\
\text { supports the monitoring and reporting on progress made in the Pacific Islands } \\
\text { Framework for Action on Climate Change (PIFACC). It is also a valuable forum for } \\
\text { sharing lessons learnt and reporting on the progress of initiatives such as the PCCP } \\
\text { [Pacific Climate Change Portal] - an online repository of information on climate } \\
\text { change in the Pacific region" (SPREP, 2013b, p. 22). Biannual meeting. Last held on } \\
\text { May 12-14, } 2015 \text {. }\end{array}$ & $\nabla$ \\
\hline & $\begin{array}{l}\text { 2. The organisation advocates for } \\
\text { political, financial and/or other } \\
\text { climate change support for its } \\
\text { Member Countries in various fora } \\
\text { at different scales. }\end{array}$ & $\begin{array}{l}\text { "In November, SPREP was accredited as a Regional Implementing Entity under the } \\
\text { Kyoto Protocol Adaptation Fund of the United Nations Framework Convention for } \\
\text { Climate Change (UNFCCC). This milestone accreditation, making SPREP one of } \\
\text { only three such Regional Implementing Entities in the world, means that we will be } \\
\text { better able to support our Pacific members to access financing from the Adaptation } \\
\text { Fund. Critically, it enables us to provide technical support and 'lessons learned' to } \\
\text { SPREP members who are seeking national accreditation themselves" (SPREP, } \\
2013 \text { b, p. 22). }\end{array}$ & $\nabla$ \\
\hline $\begin{array}{l}\text { 4. Education and } \\
\text { training }\end{array}$ & $\begin{array}{l}\text { 1. The organisation undertakes } \\
\text { climate change adaptation } \\
\text { stakeholder and/or public } \\
\text { awareness activities. }\end{array}$ & $\begin{array}{l}\text { One of SPREP's } 2013 \text { publications is the children's story, “Aia botumwaka ma aia } \\
\text { kakamwakuri ataei! The Children Take Action: A Climate Change Story” (SPREP, } \\
2013 b, \text { p. 48). } \\
\text { Details } \\
\text { Published on } 07 \text { October } 2015\end{array}$ & $\square$ \\
\hline
\end{tabular}




\begin{tabular}{|c|c|c|c|}
\hline SUB-COMPONENT & INDICATOR & EVIDENCE & RATING \\
\hline & & $\begin{array}{l}\text { Tweet } \\
\text { The Secretariat of the Pacific Regional Environment Programme (SPREP) joined the } \\
\text { 'Race Against Time' competition as part of the Annual International Alo Paopao } \\
\text { Festival, an outrigger event, in Samoa with Director-General Mr David Sheppard } \\
\text { coming third in the celebrity event. } \\
\text { PTPP1Mr. David Sheppard, Director-General of SPREP in the 'Race Against Time' } \\
\text { "Mr. Sheppard along with Mr Peniamina Leavai of the Pacific Adaptation to Climate } \\
\text { Change Project and Mr. David Moverley the Invasive Species Adviser of SPREP } \\
\text { joined local celebrities in Samoa that competed in the race, paddling a traditional } \\
\text { canoe in the Apia harbor as part of the 'Pole to Paris'. This is a public awareness } \\
\text { campaign ahead of the } 21 \text { st Conference of the Parties to the United Nations } \\
\text { Framework Convention on Climate Change (UNFCCC COP21) in Paris, France at } \\
\text { the end of the year. Climate Change (UNFCCC COP21) in Paris, France at the end } \\
\text { of the year" (SPREP, 2015h, online). }\end{array}$ & \\
\hline & $\begin{array}{l}\text { 2. The organisation develops and/or } \\
\text { implements training programs for } \\
\text { stakeholders in issues related to } \\
\text { climate change adaptation. }\end{array}$ & $\begin{array}{l}\text { In 2013, SPREP conducted training for the Samoan Government's "Ministry of } \\
\text { Natural Resources and Environment (MNRE) to enable staff to undertake regular } \\
\text { coastal erosion monitoring at Vaiula beach resort at Tafatafa, Samoa. This training is } \\
\text { one part of the Samoa coastal ecosystem-based adaptation project, funded through } \\
\text { the Australian Government" (SPREP, 2013b, p. 10). }\end{array}$ & $\nabla$ \\
\hline $\begin{array}{ll}\text { 5. } & \text { Specialised } \\
\text { advisory services }\end{array}$ & $\begin{array}{l}\text { 1. The organisation provides } \\
\text { specialised climate change } \\
\text { adaptation-related advice to } \\
\text { Member Countries and/or other } \\
\text { stakeholders. }\end{array}$ & $\begin{array}{l}\text { The "Pacific Programme on Climate Resilience with the World Bank ... will enable } \\
\text { SPREP to enhance technical support and advice to Pacific countries on climate } \\
\text { change" (SPREP, 2013b, p. 3). } \\
\text { "A ground-breaking Letter of Agreement has been signed between the Secretariat of } \\
\text { the Pacific Regional Environment Programme (SPREP) and the Republic of the } \\
\text { Marshall Islands to support the development of urgently needed climate change } \\
\text { adaptation activities. The formal Agreement will see SPREP provide capacity } \\
\text { development and technical advisory support to the Marshall Islands to develop } \\
\text { concepts and project proposals for submission to the Adaptation Fund Board. In } \\
\text { November 2013, SPREP was accredited as a Regional Implementing Entity (RIE) } \\
\text { under the Kyoto Protocol Adaptation Fund of the United Nations Framework } \\
\text { Convention for Climate Change (UNFCCC). This milestone accreditation has made } \\
\text { SPREP one of only three such RIEs in the world. With the signing of this Agreement, } \\
\text { the Marshall Islands has become the second SPREP Member country to officially } \\
\text { engage with SPREP in its capacity as RIE" (SPREP, 2014f, online). }\end{array}$ & $\nabla$ \\
\hline
\end{tabular}


Appendix 5: Application of FAROCCCA to SPREP (cont'd) 


\section{$\underline{\text { References }}$}

Abd Rahman, A., Imm Ng, S., Sambasivan, M. and Wong, F., 2013. Training and organizational effectiveness: moderating role of knowledge management process, European Journal of Training and Development, 37(5): 472488. Available at: http://dx.doi.org/10.1108/03090591311327295 (accessed April 7, 2016).

Anderson, P., 2015. Paul Anderson - LinkedIn, LinkedIn. Available at: https://www.linkedin.com/in/paul-anderson79a3b517 (accessed November 28, 2015).

APAN, 2012. SPC Training on Gender and Climate Change, Suva, Fiji, June 20-22 Asia Pacific Adaptation Network. Available at: http://www.asiapacificadapt.net/events/spc-training-gender-and-climate-change-suva-fiji-june20\%E2\%80\%9322 (accessed November 29, 2015).

Asopa, V. N. and Beye, G., 1997. Management of agricultural research: A training manual, Food and Agriculture Organisation. Available at: http://www.fao.org/docrep/w7503e/w7503e03.htm\#modern (accessed September 30, 2015).

Biermann, F. and Bauer, S., 2004. Assessing the effectiveness of intergovernmental organisations in international environmental politics, Global Environ Chang, 14(2): 189-193. Available at: http://dx.doi.org/10.1016/S09593780(03)00025-6 (accessed October 23, 2015).

Buadromo, V., 2015. Vuki Buadromo: Project Manager/Regional Civil Servant (Nonprofit Organization Management), LinkedIn. Available at: https://www.linkedin.com/in/vuki-buadromo-b913b374 (accessed November 29, 2015).

Button, S. B., Mathieu, J. E. and Zajac, D. M., 1996. Goal Orientation in Organizational Research: A Conceptual and Empirical Foundation, Organizational Behavior and Human Decision Processes, 67(1): 26-48. Available at: http://dx.doi.org/10.1006/obhd.1996.0063 (accessed November 17, 2015).

CARICOM and UNDP, 2006. Final Report - Strengthening Coastal Communities: A Workshop on Coastal Community Vulnerability and Adaptation, Caribbean Community Secretariat and the United Nations Development Programme, Belize City. Available at: http://research.fit.edu/sealevelriselibrary/documents/doc_mgr/481/Caribbean_Community_Adaptation_to\%20CC_ -_UNDP_\&_BACONGO_2006.pdf (accessed November 20, 2015).

CARICOM Secretariat, 2011a. Agreement Establishing The Caribbean Community Climate Change Centre (CCCCC) (2002), Caribbean Community Secretariat. Available at: http://www.caricom.org/jsp/secretariat/legal_instruments/agreement_ccccc.jsp?menu=secretariat (accessed October 30, 2015).

CARICOM Secretariat, 2011b. Caribbean Community Climate Change Centre (CCCCC), Caribbean Community Secretariat. Available at: http://www.caricom.org/jsp/community/ccccc.jsp?menu=community (accessed October 1, 2015).

CARICOM Secretariat, 2011c. Caribbean Planning For Adaptation To Climate Change (CPACC) Project, Caribbean Community Secretariat. Available at: http://www.caricom.org/jsp/projects/macc\%20project/cpacc.jsp (accessed November 18, 2015).

CARICOM Secretariat, 2011d. Regional Organisations and Institutions, Caribbean Community Secretariat. Available at: http://www.caricom.org/jsp/related_links/regional_organisations_institutions.jsp (accessed November 18, 2015).

Carruthers, P., 2015. Pasha Carruthers: Climate Change Adviser - North Pacific at Secretariat of the Pacific Community, LinkedIn. Available at: https://www.linkedin.com/profile/view?id=AAkAAAJonbYBqQ_z8HoKF0IS3BI7stPOQywADBk\&authType=N AME_SEARCH\&authToken=UXQU\&locale=en_US\&trk=tyah\&trkInfo=clickedVertical\%3Amynetwork\%2Ccli ckedEntityId\%3A40410550\%2CauthType\%3ANAME_SEARCH\%2Cidx\%3A1-11\%2CtarId\%3A1448729201756\%2Ctas\%3APasha\%20Carruther (accessed November 28, 2015).

CCCCC, 2008. Submission from the Caribbean Community Climate Change Centre on its Activities in Climate Modelling, Scenarios and Downscaling United Nations Framework Convention on Climate Change, Bonn. Available at: https://unfccc.int/files/adaptation/sbsta_agenda_item_adaptation/application/pdf/ccccc_april_08.pdf (accessed November 30, 2015).

CCCCC, 2012. Delivering Transformational Change 2011-21: Implementing the CARICOM 'Regional Framework for Achieving Development Resilient to Climate Change', Technical Report, Caribbean Community Climate Change Centre, Belmopan. Available at: http://www.gwp.org/Global/GWP-C\%20Files/IP\%20ccccc.pdf (accessed November 12, 2015).

CCCCC, 2014. Longstanding CARICOM Negotiator on Climate Change Reflects on the UNFCCC's 20th Anniversary, Caribbean Community Climate Change Centre. Available at: http://caribbeanclimateblog.com/tag/carlos-fuller/ (accessed November 25, 2015).

CCCCC, 2015a. 5Cs Concludes Annual Board of Governors Meeting: Expanded partnerships with CARPHA, Deeper Private Sector Partnerships, New Member and Heightened Outreach Announced, Caribbean Community Climate 
Change Centre. Available at: http://caribbeanclimateblog.com/2015/06/29/5cs-concludes-annual-board-ofgovernors-meeting-expanded-partnerships-with-carpha-deeper-private-sector-partnerships-new-member-andheightened-outreach-announced/ (accessed November 15, 2015).

CCCCC, 2015b. 2014-2018 Coastal Protection for Climate Change Adaptation in the Small Island States in the Caribbean $(K f W$ ), Caribbean Community Climate Change Centre. Available at: http://caribbeanclimate.bz/ongoingprojects/2014-2019-coastal-protection-for-climate-change-adaptation-in-the-small-island-states-in-the-caribbeankfw.html (accessed October 21, 2015).

CCCCC, 2015c. About CCCCC, Caribbean Community Climate Change Centre. Available at: http://www.caribbeanclimate.bz/governance-structure/senior-staff-at-ccccc.html (accessed October 21, 2015).

CCCCC, 2015d. CCCCC at COP 17, Caribbean Community Climate Change Centre. Available at: http://www.caribbeanclimate.bz/featured-articles/ccccc-at-cop-17.html (accessed October 21, 2015).

CCCCC, 2015e. CCCCC at COP 18, Caribbean Community Climate Change Centre. Available at: http://www.caribbeanclimate.bz/featured-articles/climate-change.html (accessed October 21, 2015).

CCCCC, 2015f. CCCCC Mission Statement, Caribbean Community Climate Change Centre. Available at: http://www.caribbeanclimate.bz/mission/mission.html (accessed October 20, 2015).

CCCCC, 2015g. Database Management System for a Regional Integrated Observing Network for Environmental Change in the Wider Caribbean, Caribbean Community Climate Change Centre. Available at: http://www.caribbeanclimate.bz/ongoing-projects/2011-2013-idb-data-management-system-dms.html (accessed October 21, 2015).

CCCCC, 2015h. Education \& Public Awareness, Caribbean Community Climate Change Centre. Available at: http://www.caribbeanclimate.bz/closed-projects/2012-1-5-stay-to-alive-education-initiative.html ） (accessed October 21, 2015).

CCCCC, 2015i. Senior Staff at CCCCC, Caribbean Community Climate Change Centre. Available at: http://www.caribbeanclimate.bz/governance-structure/senior-staff-at-ccccc.html (accessed October 21, 2015).

CCCCC, 2015j. Services, Caribbean Community Climate Change Centre. Available at: http://www.caribbeanclimate.bz/services/services.html (accessed October 21, 2015).

CCCCC, 2015k. Small Island Developing States (SIDS) Sustainable Energy Initiative SIDS DOCK, Caribbean Community Climate Change Centre. Available at: http://www.caribbeanclimate.bz/ongoing-projects/2001-2012sids-dock.html (accessed October 21, 2015).

CDEMA, n.d.-a. Climate Change Disaster Risk Reduction, Caribbean Disaster Emergency Management Agency. Available at: http://www.cdema.org/index.php?option=com content\&view=article\&id=511\&Itemid=538 (accessed November 18, 2015).

CDEMA, n.d.-b. What is CDEMA?, Caribbean Disaster Emergency Management Agency. Available at: http://www.cdema.org/index.php?option=com_content\&view=article\&id=89\&Itemid=79 $($ accessed November 18 , 2015).

CEHI, n.d. About CEHI, Caribbean Environmental Health Institute. Available at: http://www.cehi.org.lc/index.php/about (accessed November 18, 2015).

CHFI, 2014. Is research working for you? A self-assessment tool and discussion guide for health services management and policy organizations, Canadian Foundation for Healthcare Improvement, Available at: http://www.chsrf.ca/Libraries/Documents/SAT-Self-Assessment-Tool.sflb.ashx (accessed January 16, 2016).

CIMH, 2015. About CIMH, Caribbean Institute of Meteorology and Hydrology. Available at: http://www.cimh.edu.bb/?p=about (accessed November 18, 2015).

CNS, 2015. 5Cs Concludes Annual Board of Governors Meeting, Caribbean News Service. Available at: http://caribbeannewsservice.com/now/5cs-concludes-annual-board-of-governors-meeting/ (accessed November 23, 2015).

Colley, M., Haworth, A. and Firth, J., 2011. Regional Diagnostic: Climate Change and Development Research Capacities and Regional Priorities in the Caribbean, Caribbean Community Climate Change Centre, Belize. Available at: http://www10.iadb.org/intal/intalcdi/PE/2011/09296.pdf (accessed December 4, 2015).

Columbia University, 2010. Session 3: Projecting Future Climate Change Risk, Fighting for Survival: The Vulnerability of America's Gulf Coast and the Caribbean Basin, New Orleans. Columbia University. Available at: http://ffs.ei.columbia.edu/sitefiles/file/UlricTrotz_Session3transcript.pdf (accessed November 19, 2015).

Connolly, T., Conlon, E. J. and Deutsch, S. J., 1980. Organizational Effectiveness: A Multiple-Constituency Approach, The Academy of Management Review, 5(2): 211-217. Available at: http://www.jstor.org/stable/257430 (accessed December 2, 2015).

CROSQ, 2011. CROSQ welcomes New CEO, CARICOM Regional Organisation for Standards and Quality. Available at: $\quad$ https://www.crosq.org/index.php/e-library/category/20-newsletters?download=106:crosq-newsletter-vol-5issue-2 (accessed November 28, 2015). 
Cross Strait Interflow Prospect Foundation, 2010. Speaker and Moderator Profiles, Cross Strait Interflow Prospect Foundation. Available at: http://symposium.aoetek.com/cv.pdf (accessed November 23, 2015).

Daft, R. L., 2012. Organization Theory and Design, South-Western/Cengage Learning, Mason, Ohio.

DPMC, n.d. Resume - Mark Lancelot Bynoe, PhD, Development Policy and Management Consultants. Available at: http://dpmcguyana.com/mark_bynoe_resume.pdf (accessed November 23, 2015).

Earth Limited, n.d. Mid-term evaluation of the Pacific Adaptation to Climate Change (PACC) project-Pacific Islands, 2012, Earth Limited. Available at: http://earthlimited.org/projects/ (accessed November 28, 2015).

ECLAC, 2010. The Economics of Climate Change in Central America, Summary Report, Economic Commission for Latin America and the Caribbean, Santiago. Available at: http://www.cepal.org/en/publications/35229-economicsclimate-change-central-america-summary-2010 (accessed November 25, 2015).

ELDIS, 2015. Caribbean Environmental Reporters' Network (CERN), Institute of Development Studies. Available at: http://www.eldis.org/go/home\&id=3317\&type=Organisation\#.VkxRr3YrLBQ (accessed November 18, 2015).

Etzioni, A., 1960. Two Approaches to Organizational Analysis: A Critique and A Suggestion, Administrative Science Quarterly, 5(2): 257-278. Available at: http://dx.doi.org/10.2307/2390780 (accessed October 2, 2016).

Etzioni, A., 1964. Modern Organizations, Prentice Hall, Englewood Cliffs, New Jersey.

Galaz, V., Olsson, P., Hahn, T., Folke, C. and Svedin, U., 2008. The problem of fit among biophysical systems, environmental and resource regimes, and broader governance systems: insights and emerging challenges, In Institutions and Environmental Change: Principal Findings, Applications, and Research Frontiers (Eds, Young, O. R., King, L. A. and Schroeder, H.) Massachusetts Institute of Technology, Cambridge, Massachusetts \& London, England.

GCCA, 2012. GCCA: PSIS Marshall Islands, Pacific Climate Change Portal. Available at: http://projects.pacificclimatechange.net/gcca-psis-marshall-islands (accessed November 29, 2015).

GCCA and SPC, 2012. Global Climate Change Alliance: Pacific Small Islands States project: Logical Framework Version 2 (07.12.12), Global Climate Change Alliance and Secretariat of the Pacific Community, Available at: http://www2008.spc.int/images/climate-change/GCCA-PSIS\%20Logframe\%20FINAL.pdf (accessed December 1, 2015).

GCCA and SPC, 2015. Global Climate Change Alliance: Pacific Small Island States: Lessons Learnt Meeting (Colonia, Yap State, FSM, 3-4 September, 2015), Available at: http://www.pacificclimatechange.net/components/com_booklibrary/ebooks/FINAL_GCCA\%20PSIS\%20LL\%20 Report.pdf (accessed November 29, 2015).

GCCA, SPC and Government of the Republic of the Marshall Islands, 2014. Global Climate Change Alliance: Pacific Small Island States Project Design Document: Protecting Atoll Habitability, Land and Infrastructure in Ailinglaplap, Marshall Islands Global Climate Change Alliance, Secretariat of the Pacific Community and Government of the Republic of the Marshall Islands, Available at: http://www.pacificclimatechange.net/components/com booklibrary/ebooks/RMI\%20PDD\%20-\%20final\%20\%20version\%20for\%20SPC\%20website.pdf (accessed November 28, 2015).

GEF, 2013. Detail of GEF Project \#2552, Global Environment Facility. Available at: https://www.thegef.org/gef/project_detail?projID=2552 (accessed November 22, 2015).

GEF, UNDP and SPREP, 2010. Quarterly Progress Report: Second Quarter 2010, Available at: https://www.sprep.org/attachments/Climate_Change/2nd_Quarter_PACC_Progress_Report_-_2010.pdf (accessed November 29, 2015).

Government of Belize, 2005. Belize's National Capacity Self-Assessment Report, Ministry of Natural Resources, Local Government and the Environment, Belmopan City. Available at: https://www.thegef.org/gef/sites/thegef.org/files/documents/document/410.pdf (accessed November 21, 2015).

Government of Belize, 2014. Training on the Use of Sector-Specific Biophysical Models in Impact, Government of Belize. Available at: http://www.coastalzonebelize.org/?page id=761\#sthash.5mqDNrk4.dpuf (accessed November 27, 2015).

Government of St. Lucia, 2015. Regional meeting for climate change to be hosted in Saint Lucia, Government of St. Lucia. Available at: http://www.stlucianewsonline.com/regional-meeting-for-climate-change-to-be-hosted-insaint-lucia/ (accessed November 27, 2015).

Hay, J. E., Manarangi-Trott, T., Qoro, S. and Kostka, W., 2014. Midterm Review of the SPREP Strategic Plan (20112015), Raratonga, Cook Islands. Available at: https://www.sprep.org/attachments/Circulars/sprep_strategic_plan_mtr_final_report.pdf (accessed November 2, 2015).

Hicks, G. H. and Gullet, C. R., 1975. Organizations: Theory and Behaviour, McGraw-Hill, New York.

Holden, L., Pager, S., Golenko, X. and Ware, R. S., 2012. Validation of the research capacity and culture (RCC) tool: Measuring RCC at individual, team and organisation levels, Aust J Prim Health, 18(1): 62-67. Available at: http://dx.doi.org/10.1071/PY10081 (accessed November 13, 2015). 
Howes, M., Tangney, P., Reis, K., Grant-Smith, D., Heazle, M., Bosomworth, K. and Burton, P., 2015. Towards networked governance: Improving interagency communication and collaboration for disaster risk management and climate change adaptation in Australia, $J$ Environ Plann Man, 58(5): 757-776. Available at: http://dx.doi.org/10.1080/09640568.2014.891974 (accessed February 12, 2016).

Hunnam, P., Kenny, G. and Carpenter, C., 2012. Pacific Adaptation to Climate Change Project: Mid-Term Review, Secretariat of the Pacific Regional Environment Programme, United Nations Development Programme and Global Environmental Facility, Apia. Available at: http://www.seachangecop.org/sites/default/files/documents/2012\%2010\%20UNDP\%20\%20PACC_MTR\%20Report.pdf (accessed November 28, 2015).

IISD Reporting Services, 2009. UN Framework Convention on Climate Change (UNFCCC) Technical Workshop on Increasing Economic Resilience to Climate Change and Reducing Reliance on Vulnerable Economic Sectors through Economic Diversification, International Institute for Sustainable Development. Available at: http://www.iisd.ca/climate/wnwpc/ (accessed November 26, 2015).

Jamaica Observer, 2015. 5Cs to implement Green Climate Fund projects in Caribbean, Jamaica Observer. Available at: http://www.jamaicaobserver.com/news/5Cs-to-implement-Green-Climate-Fund-projects-in-Caribbean_19198006 (accessed November 26, 2015).

Leavai, P., 2015. Peniamina Leavai: Adaptation Planning Officer (SPREP), WeAdapt. Available at: https://www.weadapt.org/member/pleavai (accessed November 28, 2015).

LinkedIn, 2015. Profile: Scott Pontifex - Education Database Specialist (Development Statistics), LinkedIn. Available at: https://www.linkedin.com/in/scott-pontifex-475aa09 (accessed November 27, 2015).

Ludlow, N. P., 2006. De-commissioning the Empty Chair Crisis: the Community institutions and the crisis of 1965-6, In Visions, Votes and Vetoes :the Empty Chair Crisis and the Luxembourg Compromise Forty Years On. (Eds, Wallace, H., Winand, P. and Palayret, J.-M.) Peter Lang, Brussels, Belgium, pp. 79-96.

McDavid, J. C., Huse, I. and Hawthorn, L. R. L., 2013. Program Evaluation and Performance Measurement: An Introduction to Practice, SAGE, Los Angeles.

Miller, D. C. and Salkind, N. J., 2002. Handbook of Research Design and Social Measurement, SAGE Publications, Inc., Thousand Oaks, California.

Nakavelu, T., 2015. Mr. Taito Nakavelu: PACC Regional Project Manager, Zoominfo. Available at: http://www.zoominfo.com/p/Taito-Nakalevu/262346096 (accessed November 28, 2015).

Oberlack, C. and Neumärker, B., 2013. A Diagnostic Approach to the Institutional Analysis of Climate Adaptation, University of Freiburg, Freiburg, Germany. Available at: https://www.wipo.uni-freiburg.de/dateien/research/cenpapers/CENpaper2013_01 (accessed April 11, 2014).

OECS, 2012. OECS Secretariat to Manage a Major Protected Areas Management Project for the Sub-Region, Organisation of Eastern Caribbean States. Available at: http://www.oecs.org/press-releases/59-oecs-secretariat-tomanage-a-major-protected-areas-management-project-for-the-sub-region (accessed November 22, 2015).

Office of the President of Kiribati, 2015. Hand washing with soap will save lives, Office of the President of Kiribati. Available at: http://www.climate.gov.ki/tag/spc-eu-gcca-psis/ (accessed November 29, 2015).

PIF Secretariat, 2014. The Framework for Pacific Regionalism, Pacific Islands Forum Secretariat, Suva. Available at: http://www.adb.org/sites/default/files/linked-documents/pacific-robp-2015-2017-sd.pdf (accessed April 16, 2016).

PINA, 2013. SPC's new Deputy Director-General, Operations and Management appointed, Pacific Islands News Association. Available at: http://www.pina.com.fj/?p=pacnews\&m=read\&o=1361173516524debd6caef64c8ed38 (accessed November 27, 2015).

PreventionWeb, 2012. Caribbean conference on climate change in the coastal zone, United Nations International Strategy for Disaster Reduction Secretariat. Available at: http://www.preventionweb.net/events/view/29000?id=29000 (accessed November 27, 2015).

PreventionWeb, 2013. The caribbean weather impacts group (CARIWIG) inaugural workshop, United Nations International Strategy for Disaster Reduction Secretariat. Available at: http://www.preventionweb.net/events/view/30901?id=30901 (accessed November 27, 2015).

Quinn, R. E. and Rohrbaugh, J., 1983. A Spatial Model of Effectiveness Criteria: Towards a Competing Values Approach to Organizational Analysis, Management Science, 29(3): 363-377. Available at: http://dx.doi.org/10.2307/2631061 (accessed October 25, 2015).

Renz, D. O. and Herman, R. D., 2002. Nonprofit Organizational Effectiveness: Practical Implications of Research on an Elusive Concept, Occasional Paper, University of Missouri, Kansas City. Available at: http://www.nassembly.org/uploads/documents/webinars/nonprofitorganizationaleffectiveness.pdf $\quad$ (accessed October 19, 2015).

Robinson, S.-a., 2015. Climate change adaptation trends in small island developing states, Mitigation Adapt Strateg Glob Chang: 1-23. Available at: http://dx.doi.org/10.1007/s11027-015-9693-5 (accessed December 20, 2015). 
Schmitter, P. C., 2003. Neo-Neo-Functionalism, In European Integration Theory (Eds, Wiener, A. and Diez, T.) Oxford University Press, Oxford.

Sheppard, D., 2015. David Sheppard: CEO at Secretariat of the Pacific Regional Environment Programme, LinkedIn. Available at: https://www.linkedin.com/in/david-sheppard-0922b123 (accessed November 29, 2015).

Solomon Times Online, 2011. SPC and GIZ Announce Assistance to Pacific Coastal Fisheries to Cope with Climate Change, Solomon Times Online. Available at: http://www.solomontimes.com/news/spc-and-giz-announceassistance-to-pacific-coastal-fisheries-to-cope-with-climate-change/6674 (accessed November 29, 2015).

Sowa, J. E., Selden, S. C. and Sandfort, J. R., 2004. No Longer Unmeasurable? A Multidimensional Integrated Model of Nonprofit Organizational Effectiveness, Nonprofit and Voluntary Sector Quarterly, 33(4): 711-728. Available at: http://dx.doi.org/10.1177/0899764004269146 (accessed October 19, 2015).

SPC-SOPAC, 2015. Climate Change Unit (USAID Project and EU-GCCA Project), SPC - Geoscience Division. Available at: http://ict.sopac.org/WebConsole/frontStaff/showProgramme/4653057 (accessed November 29, 2015).

SPC - Geoscience Division, 2013a. Disaster Risk Management and Climate Change Training for SPC staff Secretariat of the Pacific Community - Geoscience Division. Available at: http://202.62.0.20/media-releases/1-latest-news/524disaster-risk-management-and-climate-change-training-for-spc-staff (accessed November 27, 2015).

SPC - Geoscience Division, 2013b. New Director For SOPAC/SPC Division Sectreatariat of the Pacific Community Geoscience Division. Available at: http://gsd.spc.int/media-releases/1-latest-news/472-new-director-for-sopacspcdivision (accessed November 27, 2015).

SPC - Geoscience Division, 2015. Snapshots: Disaster Reduction Programme, Secretariat of the Pacific Community, Available at: http://reliefweb.int/sites/reliefweb.int/files/resources/SPC_2015_Snapshots_87.pdf (accessed November 27, 2015).

SPC - Land and Resources Division, 2013. Samoan agricultural staff trained at SPC, Secretariat of the Pacific Community Land and Resources Division. Available at: http://www.spc.int/lrd/our-work/genetic-resources/centrefor-pacific-crops-and-trees/samoan-agricultural-staff-trained-at-spc (accessed November 29, 2015).

SPC, 1947. Canberra agreement: Agreement establishing the South Pacific Commission, Secretariat of the Pacific Community, Canberra, Australia. Available at: http://www.spc.int/images/stories/About_SPC/CanberraAgreement.pdf (accessed December 4, 2015).

SPC, 2004. Thirty-Fourth Meeting of the Committee of Representatives of Governments and Administrations (Noumea, New Caledonia, November 16-19, 2004): The Year 2005 Budget and Assessed Contributions: Withdrawal of the United Kingdom from the Pacific Community, Available at: http://www.spc.int/DigitalLibrary/Doc/SPC/Meetings/CRGA/CRGA 34/CRGA 34 Paper 11 E.pdf (accessed November 27, 2015).

SPC, 2007. Secretariat of the Pacific Community (SPC) Corporate Plan (2007-2012), Noumea, New Caledonia. Available

http://www.spc.int/DigitalLibrary/Doc/SPC/Meetings/CRGA/CRGA 36/CRGA 36 Paper 431 Corporate Pla n_2007_12_E.pdf (accessed December 3, 2015).

SPC, 2010a. Annual report 2009 Secretariat of the Pacific Community: Part 2 - annual accounts, Secretariat of the Pacific Community, Noumea, New Available at: http://www.spc.int/DigitalLibrary/Doc/SPC/Annual_Reports/en_annual_report_2009_part2.pdf ） (accessed December 3, 2015).

SPC, 2010b. Secretariat of the Pacific Community (SPC) Annual Report 2009 - Part 1: Annual Overview, Secretariat of the Pacific Community, Noumea, New Caledonia. Available at: http://www.spc.int/DigitalLibrary/Doc/SPC/Annual_Reports/en_annual_report_2009_part1.pdf $\quad$ (accessed December 3, 2015).

SPC, 2011a. Forty-First Meeting of the Committee of Representatives of Governments and Administrations: Agenda Item 8.1 - Directorate of Operations and Management, Secretariat of the Pacific Community, Available at: http://www.spc.int/DigitalLibrary/Doc/SPC/Meetings/CRGA/CRGA 41/CRGA 41 Paper 81 Directorate of Operations_and_Management.pdf (accessed November 29, 2015).

SPC, 2011b. Global Climate Change Alliance: Pacific Small Island States Project - Environmental monitoring to enhance community livelihoods and build resilience to climate change in the low lying atolls of the Cook Islands, Global Climate Change Alliance and Secretariat of the Pacific Community, Available at: http://www.spc.int/images/climate-change/GCCA-PSIS_docs/Cook_Islands/gccapsis_concept_note_cook_islands.pdf (accessed November 29, 2015).

SPC, 2011c. History of the Secretariat of the Pacific Community, Secretariat of the Pacific Community. Available at: http://www.spc.int/en/about-spc/history.html (accessed November 6, 2015).

SPC, 2011d. Internal Climate Change Engagement Strategy for the Secretariat of the Pacific Community, Secretariat of the Pacific Community, Available at: 
November 5, 2015).

SPC, 2011e. Tahiti Nui Declaration Secretariat of the Pacific Community, Available at: http://www.spc.int/images/publications/ef/Corporate/ef-tahiti-nui-declaration.pdf (accessed August 12, 2015).

SPC, 2012. Global Climate Change Alliance: Pacific Small Island States, Secretariat of the Pacific Community, Available at: http://www.spc.int/images/climate-change/brief2.pdf (accessed November 2, 2015).

SPC, 2013. Corporate Strategic Plan (2013-2015), Secretariat of the Pacific Community, Noumea, New Caledonia. Available at: http://www.spc.int/images/publications/en/Corporate/corporate-plan.pdf (accessed November 2, 2015).

SPC, 2014a. Appointment announcement Director of SPC's Fisheries, Pacifc.Scoop, Available at: http://pacific.scoop.co.nz/2014/01/appointment-announcement-director-of-spcs-fisheries/ (accessed November 27, 2015).

SPC, 2014b. Forty-Fourth Meeting of the Committee of Representatives of Governments and Administrations (Noumea, New Caledonia, November 4-7, 2014): Agenda Item 7: Operations and Management Directorate Report: Agenda Item 7.3: 2014 Revised and 2015 Proposed Budgets Available at: http://www.spc.int/crga/sites/default/files/documents_uploads/CRGA44\%20-

$\% 207.3 \% 202014 \% 20$ Revised\%20budget\%20and\%202015\%20proposed\%20budgets_0.pdf (accessed November 28, 2015).

SPC, 2014c. Global Climate Change Alliance: Pacific Small Island States Project: Progress Report for Period 1 January - 30 June 2014, Secretariat of the Pacific Community, Available at: http://www.pacificclimatechange.net/index.php/eresources/documents?task=view\&id=1245\&catid=245 (accessed November 23, 2015).

SPC, 2014d. Paper 7.4 - Reports on Human Resources: Staff Development and Retention, Secretariat of the Pacific Community, Noumea. Available at: http://www.spc.int/DigitalLibrary/Doc/SPC/Meetings/CRGA/CRGA_44/CRGA_44_Paper_7_4_Reports_on_Hu man_Resources_Staff_Development_and_Retention_E.pdf (accessed November 27, 2015).

SPC, 2014e. SPC's New Director-General, Secretariat of the Pacific Community. Available at: http://www.spc.int/en/spc-and-the-pacific-plan/1549-spcs-new-director-general.html (accessed November 27, 2015).

SPC, 2014f. SPC Annual report 2013, Secretariat of the Pacific Community, Noumea, New Caledonia. Available at: http://www.spc.int/DigitalLibrary/Doc/SPC/Annual Reports/en annual report 2013.pdf (accessed November 8, 2015).

SPC, 2014g. SPC Programme Results Report 2013 - 2014, Secretariat of the Pacific Community, Noumea, New Caledonia. Available at: http://www.spc.int/images/publications/en/Corporate/SPC-Programme-ResultsReport.pdf (accessed November 27, 2015).

SPC, 2015a. Forty - Fifth Meeting Of The Committee Of Representatives Of Governments And Administrations ( Alofi, Niue, 31 October - 2 November 2015 ): Agenda Item 9.3: 2015 Revised Budget And 2016 Proposed Budget Secretariat of the Pacific Community, Available at: http://www.spc.int/crga/sites/default/files/crga_papers/CRGA\%2045\%20Paper\%209.3\%20\%20Revised\%202015\%20Budget\%20-\%202016\%20Budget.pdf (accessed November 29, 2015).

SPC, 2015b. More TV stations to air The Pacific Way show, Secretariat of the Pacific Community. Available at: http://www.spc.int/en/media-releases/2159-more-tv-stations-to-air-the-pacific-way-show.html

(accessed November 29, 2015).

SPC and Government of the Federated States of Micronesia, 2013. Global Climate Change Alliance: Pacific Small Island States: Draft Project Design Document (Increasing Coastal Water and Food Security for Climate Change in Selected FSM State Outlying Islands), Secretariat of the Pacific Community, Available at: http://www.spc.int/images/climate-change/GCCA-PSIS docs/FSM/gcca-psis projectdesigndoc fsm.pdf (accessed November 29, 2015).

SPC and SOPAC, 2010. Strategic Plan 2011-2015, Available at: http://gsd.spc.int/sopac/docs/SPC\%20SOPAC\%20Division\%20Strategic\%20Plan\%202010-2015\%20final.pdf (accessed December 1, 2015).

SPC and SOPAC, 2012. Second Meeting of the SOPAC Division Noumea, New Caledonia, 3-9 November 2012 (2013 SOPAC Division Work Plan and Budget: 2013 Proposed Work Plan And Budget), Secretariat of the Pacific Community, Noumea, New Caledonia. Available at: http://gsd.spc.int/sopac/docs/sopac2/SOPAC2_5_2012_WPlan\&Budget.pdf (accessed November 29, 2015).

SPC and Government of the Cook Islands, 2012. Project Design Document: Environmental Monitoring to Enhance Community Livelihoods and Build Resilience to Climate Change in Low - Lying Atolls of the Cook Islands Secretariat of the Pacific Community \& The Government of the Cook Islands, Available at: 
http://www.spc.int/images/climate-change/GCCA-PSIS_docs/Cook_Islands/gcca-psis_projectdesigndoc_ci.pdf (accessed November 29, 2015).

SPREP, 1993. Agreement Establishing the South Pacific Regional Environment Programme, South Pacific Regional Environment Programme, Apia, Samoa. Available at: https://www.sprep.org/att/publication/000128_Agreement_Establishing_SPREP.PDF (accessed August 19, 2015).

SPREP, 1995. Rules of Procedure of SPREP Meeting, Secretariat of the Pacific Regional Environment Programme, Apia, Samoa. Available at: https://www.sprep.org/attachments/Legal/RULESofProcedureoftheSPREPMeeting.pdf (accessed November 2, 2015).

SPREP, 2011a. Secreatriat of the Regional Environment Programme, Apia, Samoa.

SPREP, 2011b. Pacific Regional Environment Programme Strategic Plan 2011 - 2015, Secretariat of the Pacific Regional Environment Programme, Apia, Samoa. Available at: https://www.sprep.org/att/publication/000921_SPREPStrategicPlan2011_2015.pdf (accessed November 24, 2015).

SPREP, 2011c. Vacancy: Pacific Islands Global Ocean Observing System Coordinator (PIGOOSC), Secretariat of the Pacific Regional Environment Programme, Apia, Samoa. Available at: https://www.sprep.org/attachments/Employment/SPREP_PIGOOSC_Ad_JD_14_February_2011_FINAL.pdf (accessed November 28, 2015).

SPREP, 2011d. Work Programme and Budget for 2012, Secretariat of the Pacific Regional Environment Programme, Apia, Samoa. Available at: https://sprep.org/att/publication/000939 WP Budget 2012.pdf (accessed November 11, 2015).

SPREP, 2012a. 2011 Annual Report of the Secretariat of the Pacific Regional Environment Programme, Secretariat of the Pacific Regional Environment Programme, Apia, Samoa. Available at: https://www.sprep.org/publications/sprep-annual-report-2011 (accessed November 24, 2015).

SPREP, 2012b. Pacific women in climate change - meet Dr Netatua Pelesikoti, Tonga, Secretariat of the Pacific Regional Environment Programme. Available at: https://www.sprep.org/climate-change/pacific-women-in-climatechange-meet-dr-netatua-pelesikoti-tonga (accessed November 28, 2015).

SPREP, 2013a. Adapting to Climate Change in the Pacific: The PACC Programme, Secretariat of the Pacific Regional Environment Programme, Apia, Samoa. Available at: https://www.sprep.org/attachments/Publications/CC/PACC_Programme.pdf (accessed December 3, 2015).

SPREP, 2013b. Annual Report 2013 - Secretariat of the Pacific Regional Environment Program, Secretariat of the Pacific Regional Environment Program, Apia, Samoa. Available at: http://www.sprep.org/attachments/Publications/Corporate Documents/AnnRep2013.pdf (accessed September 15, 2015).

SPREP, 2013c. Approved Work Programme and Approved Budget for 2014, Secretariat of the Pacific Regional Environment Programme, Available at: http://www.sprep.org/attachments/Publications/Corporate Documents/WPB2014.pdf (accessed November 28, 2015).

SPREP, 2014a. Annual Report 2014, Secretariat of the Pacific Regional Environment Programme, Apia, Samoa. Available at: https://www.sprep.org/publications/sprep-annual-report-2014 (accessed August 20, 2015).

SPREP, 2014b. Circular AP 3/1/1: Staff Announcement (Taito Nakalevu Resignation), Secretariat of the Pacific Regional Environment Programme, Available at: https://www.sprep.org/attachments/Circulars/Cir14-07.pdf (accessed November 28, 2015).

SPREP, 2014c. Our Team, Secretariat of the Pacific Regional Environment Programme. Available at: https://www.sprep.org/our-team (accessed November 2, 2015).

SPREP, 2014d. Pacific Ecosystem Based Adaptation to Climate Change Project Manager Job Description, Secretariat of the Pacific Regional Environment Programme, Available at: https://www.sprep.org/attachments/SPREP PEBACC PM Job Description Oct 2014 FINAL.pdf (accessed December 4, 2015).

SPREP, 2014e. Report of the Twenty Fifth (25th) SPREP Meeting, 30th September - 3rd October, Majuro, Marshall Islands, Secretariat of the Pacific Regional Environment Program, Apia, Samoa. Available at: https://www.sprep.org/sprep-meeting/25th-sprep-meeting-of-officials (accessed December 5, 2015).

SPREP, 2014f. SPREP and Marshall Islands formalise agreement to support adaptation activities, Secretariat of the Pacific Regional Environment Programme. Available at: https://www.sprep.org/climate-change/sprep-andmarshall-islands-formalise-agreement-to-support-adaptation-activities (accessed November 27, 2015).

SPREP, 2014g. Website - Pacific Climate Change Roundtable, Secretariat of the Pacific Regional Environment Programme. Available at: https://www.sprep.org/table/pacific-climate-change-roundtable/ (accessed November 5, 2015). 
SPREP, 2015a. Adaptation, Loss and Damage: Application to the UNFCCC, UNFCCC. Available at: https://unfccc.int/files/adaptation/cancun_adaptation_framework/loss_and_damage/application/pdf/sprep.pdf (accessed November 29, 2015).

SPREP, 2015b. Applicant Information Package (Director General), Secretariat of the Pacific Regional Environment Programme, Available https://www.sprep.org/attachments/Employment/SPREP DIRECTOR GENERAL Job Description January 20 15_FINAL_copy.pdf (accessed November 2, 2015).

SPREP, 2015c. Applicant Information Package: Director, Climate Change (DCC), Secretariat of the Pacific Regional Environment Programme, Available at: https://www.sprep.org/attachments/Employment/SPREP DCC Job Description November 2015 FINAL.pdf (accessed November 26, 2015).

SPREP, 2015d. PACC Demonstration Guide: Piloting climate change adaptation in food production and food security on low-lying atolls of Solomon Islands, Secretariat of the Pacific Regional Environment Programme, Available at: http://www.sprep.org/attachments/Publications/CC/PACCTechRep19.pdf (accessed November 27, 2015).

SPREP, 2015e. Performance Monitoring and Evaluation Report (PMER) on the 2014 Work Programme and Budget, Secretariat of the Pacific Regional Environment Programme, Available at: https://www.sprep.org/attachments/2015SM26/official/WP_5.2.Att.1_-_PMER_2014Final.pdf (accessed November 27, 2015).

SPREP, 2015f. PI-GOOS Home, Secretariat of the Pacific Regional Environment Programme. Available at: https://www.sprep.org/pi-goos (accessed November 29, 2015).

SPREP, 2015g. Secretariat of the Pacific Regional Environment Programme: Financial Statements for the Year Ended 31 December 2014 Secretariat of the Pacific Regional Environment Programme, Available at: https://www.sprep.org/attachments/2015SM26/official/WP 5.3 Att 1.rev.1 _Audited_Annual_Accounts_2014.pdf (accessed December 3, 2015).

SPREP, 2015h. SPREP competes in the Climate Change "Race Against Time", Secretariat of the Pacific Regional Environment Programme. Available at: https://www.sprep.org/climate-change/sprep-joining-the-climate-changeqrace-against-timeq (accessed November 27, 2015).

SPREP and SOPAC, 2010. Letter of Agreement between The Pacific Islands Applied Geoscience Commission (SOPAC) and the Secretariat of the Pacific Regional Environment Programme (SPREP), Available at: http://gsd.spc.int/sopac/docs/RIF/04a_SOPAC\%20\&\%20SPREP.pdf (accessed November 29, 2015).

SPTO, 2015. Pacific Community staff in Fiji, Vanuatu, Kiribati and New Caledonia honoured at annual awards, South Pacific Tourism Organisation. Available at: http://spto.org/news/item/4041-pacific-community-staff-in-fijivanuatu-kiribati-and-new-caledonia-honoured-at-annual-awards (accessed November 29, 2015).

Taylor, C. M., Cornelius, C. J. and Colvin, K., 2014. Visionary leadership and its relationship to organizational effectiveness, Leadership \& Organization Development Journal, 35(6): 566-583. Available at: http://dx.doi.org/10.1108/LODJ-10-2012-0130 (accessed October 20, 2015).

The Kingdom of Tonga, 2010. Joint National Action Plan on Climate Change Adaptation and Disaster Risk Management 2010-2015, The Kingdom of Tonga, Available at: https://sustainabledevelopment.un.org/content/documents/1335tongaDisaster\%20Management\%20Strategy.pdf (accessed November 27, 2015).

The Voice, 2008. SPACC: Making the Marchand Community Centre Resilient to Climate Change, The Voice Publishing Company. Available http://www.thevoiceslu.com/features/2008/july/08_07_08/SPACC_Making_the_Marchand_Community_Centre_ Resilient_to_Climate_Change.htm (accessed November 28, 2015).

Underdal, A., 2010. Complexity and challenges of long-term environmental governance, Global Environ Chang, 20(3): 386-393. Available at: http://www.sciencedirect.com/science/article/pii/S0959378010000117 (accessed October 31, 2015).

UNDP and SPREP, 2008. Pacific Adaptation to Climate Change (PACC), United Nations Development Program and Secretariat of the Pacific Regional Environment Programme, Available at: https://www.sprep.org/attachments/Climate Change/PACC Project description - Final.pdf (accessed November 10, 2015).

UNEP-REGATTA, 2015. University of the West Indies - St. Augustine (UWI), United Nations Environment Programme. Available at: http://www.cambioclimatico-regatta.org/index.php/en/key-institutions/item/university-of-westindies-st-augustine-uwi (accessed November 1, 2015).

UNEP, 2005. Pacific Island Villagers First Climate Change "Refugees", United Nations Environment Programme Available at: http://www.unep.org/Documents.Multilingual/Default.asp?DocumentID=459\&ArticleID=5066\&l=en (accessed November 28, 2015). 
UNEP CEP, 1998. Workshop on Maritime Treaties and International Environmental Agreements: Toward National and Regional Actions, United Nations Environment Programme. Available at: http://www.cep.unep.org/pubs/cepnews/v13n3/page16.htm (accessed November 26, 2015).

UNFCCC Secretariat, 2009. Synthesis report on approaches to and experiences in integrating and expanding adaptation planning and action, and lessons learned, good practices, gaps, needs, and barriers and constraints to adaptation, United Nations Framework Convention on Climate Change, Bonn. Available at: http://www.unisdr.org/files/11623_061.pdf (accessed November 30, 2015).

UNFCCC Secretariat, 2010. List of Participants - UNFCCC Latin America and Caribbean Regional Workshop on Preparing Technology Transfer Projects for Financing, 5-7 May 2010, Belize City, Belize, United Nations Framework Convention Climate Change, Bonn. Available http://unfccc.int/ttclear/misc_/StaticFiles/gnwoerk_static/events_workshops_TrainingWorkshopBelize/35ac9d2a6 dc84fbcae1ce96b81b5b52e/2f53fce8db2d4df6be651a2951af0259.pdf (accessed November 25, 2015).

UNFCCC Secretariat, 2014. Provisional List of Participants - UNFCCC Conference of the Parties, Twentieth Session, Lima, 1-12 December 2014, United Nations Framework Convention on Climate Change Secretariat, Bonn. Available at: http://unfccc.int/resource/docs/2014/cop20/eng/misc01p02.pdf (accessed November 23, 2015).

UNFCCC Secretariat, 2015. Provisional List of Participants - Ad Hoc Working Group on the Durban Platform for Enhanced Action, Second Session, Part Eleven, Bonn, 19-23 October 2015, United Nations Framework Convention on Climate Change, Bonn. Available at: http://unfccc.int/resource/docs/2015/adp2/eng/misc03.pdf (accessed November 25, 2015).

United Nations, 2006. Kenrick $R$. Leslie, United Nations. Available at: http://www.un.org/ga/president/61/followup/climatechange/leslie.shtml (accessed November 4, 2015).

UPRM, n.d. Brief Biography - Leonard A. Nurse, University of Puerto Rico. Available at: http://cohemis.uprm.edu/cacce/pdfs/bio Nurse.pdf (accessed November 2, 2015).

UWI, 2015. About CSGM, University of the West Indies. Available at: https://www.mona.uwi.edu/physics/csgm/about (accessed November 19, 2015).

Väyrynen, R., 2003. Regionalism: old and new, International Studies Review, 5(1): 25-51. Available at: http://dx.doi.org/10.1111/1521-9488.501002 (accessed April 9, 2016).

Weiss, C. H., 2005. Evaluation Research: Methods for Assessing Program Effectiveness, Prentice-Hall Inc., Englewood Cliffs, New Jersey.

Williams-Raynor, P., 2015. UWI, IDB Launch Investment Plan For Regional Climate Change Programme, The Gleaner. Available at: http://jamaica-gleaner.com/article/lead-stories/20151118/uwi-idb-launch-investment-plan-regionalclimate-change-programme (accessed November 18, 2015).

WMO, 2008. Fourth Meeting of the GCOS Cooperation Board, World Meteorological Organization, Geneva. Available at: https://www.wmo.int/pages/prog/gcos/Publications/gcos-123.pdf (accessed November 25, 2015).

Wolfe, R. A. and Putler, D. S., 2002. How Tight Are the Ties that Bind Stakeholder Groups?, Organization Science, 13(1): 64-80. Available at: http://dx.doi.org/10.1287/orsc.13.1.64.544 (accessed December 13, 2015).

World Bank, 2006. Project Executive Summary: Implementation of Pilot Adaptation Measures in coastal areas of Dominica, St. Lucia and St. Vincent \& the Grenadines, World Bank, Washington, D.C. Available at: https://www.thegef.org/gef/project_detail?projID=2552 (accessed November 29, 2015).

World Bank, 2011. Specific Procurement Notice: Implementation of Adaptation Measures in Coastal Zone Project (TF056744) - Procurement and Installation of Photovoltaic System for Bequia, St. Vincent and the Grenadines (SPACC-ICB-SV-03), World Bank. Available at: http://www.worldbank.org/projects/procurement/noticeoverview?id=OP00006759\&lang=en\&print=Y (accessed October 20, 2015).

World Bank, 2012. Implementation Completion and Results Report (TF-56744) on a Grant in the Amount of US\$2.1 Million to the Commonwealth of Dominica, St. Lucia, and St. Vincent and the Grenadines through the Caribbean Community Climate Change Centre (CCCCC) for the Implementation of Adaptation Measures in Coastal Zones Project, Implementation Completion and Results Report, World Bank, Washington, D.C. Available at: http://www.thegef.org/gef/sites/thegef.org/files/gef prj docs/GEFProjectDocuments/MandE/EO TEs FY13/Wor ldBank TEs APR2013/2552 WB TE P090731-ICR Caribbean.pdf (accessed November 20, 2015).

World Economic Forum, 2014. Effective Leadership in International Organizations, World Economic Forum, Geneva. Available at: http://www3.weforum.org/docs/WEF_Effective_Leadership_International_Organizations_report.pdf (accessed October 23, 2015).

Young, O. R., 2011. Effectiveness of international environmental regimes: Existing knowledge, cutting-edge themes, and research strategies, Proc. Natl. Acad. Sci., 108(50): 19853-19860. Available at: http://dx.doi.org/10.1073/pnas.1111690108 (accessed October 24, 2015).

Yukl, G., 2008. How leaders influence organizational effectiveness, The Leadership Quarterly, 19(6): 708-722. Available at: http://dx.doi.org/10.1016/j.leaqua.2008.09.008 (accessed October 20, 2015). 